University of Louisville

ThinkIR: The University of Louisville's Institutional Repository

1939

\title{
The sixth grade supplementary history text : educational standards and the extent to which five books meet these requirements.
}

Mabel MacDonald Schrodt

University of Louisville

Follow this and additional works at: https://ir.library.louisville.edu/etd

Part of the Educational Methods Commons

\section{Recommended Citation}

Schrodt, Mabel MacDonald, "The sixth grade supplementary history text : educational standards and the extent to which five books meet these requirements." (1939). Electronic Theses and Dissertations. Paper 1899.

https://doi.org/10.18297/etd/1899

This Master's Thesis is brought to you for free and open access by ThinkIR: The University of Louisville's Institutional Repository. It has been accepted for inclusion in Electronic Theses and Dissertations by an authorized administrator of ThinkIR: The University of Louisville's Institutional Repository. This title appears here courtesy of the author, who has retained all other copyrights. For more information, please contact thinkir@louisville.edu. 


\title{
UNIVERSI OF LOUISVILLE
}

THE SIXTH GRADE SUPPLEUENTARY HISTORY TEXT

(EDUCATIONAL STANDARDS AND THE EXTENT TO

FHICH FIVE BOOKS UEET THESE REQUTREMENTS)

\author{
A Dissertation \\ Subini tted to the Faculty \\ of the Graduate School of the University of Loulsvilie \\ In Partial Fulfiliment of the \\ Requirements for the Degree \\ of Master of Solence
}

Department of Education

By

UABEL MACDONALD SCHRODT

1939

50569 


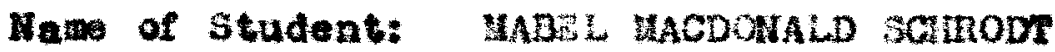

T1te of Theals: TiE SIXTI GLADE SUPPLEENTARY IIIGTORY TEXT (RDUCATIONAL 3TANARDS AND THE EXXEN TO WIICH FIVE

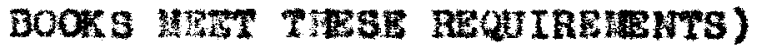

Name of Director:

Approved by a Reading Conat theo composed of the following nemers:

1.

2.

3.

4.

Bepresentative of the Departaent of Engliah:

Date: 1939 
TIE SIXTH GRADE SUPPLEMLNTARY HI STORY TEXT

(EDUCATIONAL STANDARDS AND THE EXTENT TO

WHICH FIV BOOKS AEST TISSE RRQUTREMENTS)

UABQL WACDONALD SCIRODT 
TIE SIXTH GRADE SUPPLEHEN TARY HISTORY TEXT (EDUCATIONAL STANDARDS AWD THE BXTENT TO WHICH FIVE BOOKS WRET THESE REQUIREHENTS) 
TABLI OF CONTENTS

Paste

Chapter I Introduotion................... 1

1. The Problom................... 1

History books analyred.......... 2

Criteria for roobulary analysia... 3

Criteria for determining the sultability of the history books.. 4

Chapter II Literature of the Fleld........... 6

1. Voabulary in Reading............ 6

Sorne Diffloultios in Elsmentary Sohooi Hiatory, by Ayer......... 8

The Aating of the Voogbulary of Six Aiserioan History Textbooks for the Seventh and Elghth Grades. by $\operatorname{smith} \ldots \ldots \ldots \ldots \ldots \ldots \ldots$

A Readlng Vogabulary for the

Primary Grades, by Gates......... 10

2. Comprehenst on in Reading.......... il

Vocabulary-sentence-burden and comprehansi on................ 11

Studies which show the effect of vocabulary upon corprehensi on..... 19

Rate and depth of comprehenaion of sentences.......................

Laok of comprehensi on leads to

varballsm and over-potency........

3. Summary of the Literature of the

Field.

Chapter III Experimental and Anaiytieal Procedures 41

1. Selection of Materials............ 41

2. Vocabulary Analysis.............. 43 
Page

3. Sentence and Phrase Analysis....... 47

Sentences and phrases to the

paragraph................... 48

Sentence - and phrase- length..... 48

4. Analysi s of Test Scores............. 49

5. Equation of Groups............... 51

6. Analysis of Data to Determine the

Degree to Which the Samples Were

Representative of the Books from

Which They Were Taken............. 56

7. Comparison of the Flre Books........ 60

Comparison for rocabulary.........61

Comparison for sentence-length.... 62

Comparison for phrase-length...... 63

Coinparison for degree of compre. hension with whioh the selections

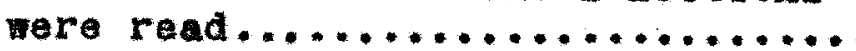

8. Reliabilities of the Tests of Comprehensi on................... 65

9. Sultability of the Books for the Groups That Use Them............. 67

10. Sumnary of Experimental and Analytical Procodures........................

Chapter IV Statistical Analyses of the Representativeness of Selections from the Five Supplementary History Books......

1. Criteria for Comparing the Tro

Halves of the Samplings $f$ or

Representativeness............... 7

Comparison for the number of words

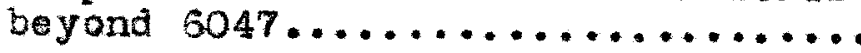

Conparison for number of words to

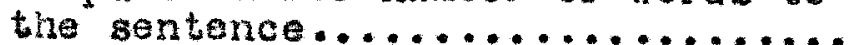


Pare

Comparison $f$ or the number of words to the phrase................... 92

Comparison $f$ or the number of sentences to the paragraph......... 98

Comparison for the number of phrases to the paragraph........... 104

Comparison for the degree of comprehenstion with which the selections were read and the questions answe red...................... 110

2. Sumnary of Statistical Analyse $s$ of Representativeness of the Selections from the Five Supplementary History Books......................... 122

Chapter V Analyais of the Five supplementary Hi story Books for Vocabulary and Sentence - and Phrase-Length......... 123

1. Vooabulary Analysi.$\ldots \ldots \ldots \ldots \ldots \ldots .123$

Difference between books for per cent of words beyond $6047 \ldots \ldots \ldots . .134$

Per cent of words beyond a frequency value of 6047 for the five supplementary history books... 136

2. Sentence and Phrase Analyais........ 137

Comparison of the five books for sentence-length (words)........... 149

Books ranked as to sentence-length (words)...................... 150

Comparison of the $f$ ive books for sentences to the paragraph........ 153

Books ranked as to number of sentences to the paragraph........ 155

Comparison of the live books for phrase-length (words)............ 155

Books ranked as to phrase-length (words) ...................... 158

Conparison of the Pive books for the number of phrases to the paragraph. 158 
Books ranked as to the number of phrase to the paragraph........... 161

Comparison of the II ve books for the number of phrases to the sentence......................... 162

Books ranked as to average number of phrases to the sentence.......... 164

Summary of book rankings .......... 165

3. Sumary of Vocabulary Analyst of the Five Books..................... 166

4. Analysis of the Five Books with Respect to Sultability for Sixth-A Grade Pupils.......................... 169

vocabulary range.................. 169

Degree of comprehensi on with which Sixth-A pupils read the five books.. 169

Sumary of data for the tive books.. 182

5. Sumnary for Suitability of the Five Supplementary HL story Books for the Groups That Use Them................ 183

Chapter VI The Degree of Comprehenstion with whioh the Five Supplementary H1 story Books Tere Read by Slxth-A Chlidren......... 184

1. Equating the Groups............... 184

Equation of groups on ohronologleal

age......................... 185

Equation of group on mental age.... 191

Equation of groups on reading age... 195

Suminary for the equation of groups.. 199

2. Testing for Comprehension............200

Degree of comprahenaion with

chronol ogl cal age held constant.....200

Degree of conprehension with mental

ago he ld constant............... 208 
Degree of comprehengion with reading age hold constant.......... 215

3. Surmary of Analysis of Degree of Comprehension with mich the Selectlons Tore Read by Sixth-A 225

Chapter VII General Summary

Summary and interpretation of tho entire study-11 terature, vocabulary and sentence - and-phrage analyses, and experiment.................... 228

Chapter VIII Appendixes

Appendix A: Original data for the tive groups of children used in the study........................ 235

Appendix B: Tests of Hiatory Comprehensi on.................... 288 
PAGE

I. SUBJECTS OF THE SEVENTERN PARAGRAPHS CHOSEN F OR AMALYSIS

42

II. MEANS, STANDARD DEVIATIONS AND RELIABILITIES OF THE TESTS OF COMPREHEISION

66

III. ONE UALF TIE PARAGRAPS COMPARED ITTH THE OTHER HALF AS TO NUHBER OF FORDS BIYOND 6047-BOOK I

81

IV.

ONE HALF THE PARAGRAPISS COUPARED VITH THE OTHEA HALF AS TO NUMBER OF FCRDS BE YOND 6047-BOOK II

V.

ONE HALF THE PARAGRAFHS COMPARED ITI TH THE OTHER HALF AS TO NUMBER OF WORDS BETOND 6047-BOOK III

VI.

ONE HALT THE PARAGRAPIS COMPARED II TH THE OTHER HALF AS TO NUABER OF MORDS BEYOND 6047-BOOK IV

VII. ONE HALF THE PARAGKAPHS COUPARED WTTH TIE OTHBR HALF AS TO NUMBER OF WORDS BEYOND 6O47-BOOK V

VIII. ONE HALE THE PARAGRAPUS COMPARED WITH THE OTHER HALF AS TO NUMBER OF WORDS TO THE BENTEKCE-BOOK I

IX. ONE HALF THE PARAGRAPHS COMPARED WITH THE OTHER HALF AS TO NUUBB $O$ OF WORDS TO THE SENTENCE-BOOK II

X. ONE HALF THE PARAGRAPHS COMPARED IITH THE OTHER HALF AS TO NUABER OF WORDS TO THE SENTENCE-BOOK III

XI. ONE HALF THE PARAGRAPHS COLPARED WITH THE OTHER HALF AS TO NURBER OF TORDS TO THE SENTENCE-BOOK IV

XII.

ONS HALF THE PARAGRAPHS COMPARED VITH TIE OTHEH HAL AS TO NUMBER OF WORDS TO THE SENTENCE-BOOK $\nabla$

XIII. ONE HALF THE PARAGRAPHS COMPARED WITK THE OTHER HALF AS TO NUMBSR OF FORDS TO TIE PIRASE-BOOK I 
Pact

XIV. OHE HALF TUE PARAGRAFHS COMPARED WITH THE OTHE HALF AS TO WUMBR OF WORDS TO THE FHRABE-BOOK II

XV. ONE IIALE THE PARAGRAPUS COMPARDD WT TH THE OTHER HALF AS TO NUBBER OF WORDS TO TEE PHRASE-BOOK III

XVI. ONE HALF THE PARAGRAPHS COMPARED WITH THE OTHER IALF AS TO NUEBEZ OF WORDS TO THE PIRASE-BOOK IV

XVII. ONE HALF THE PARAGRAPHS COMPARED WITH THE OTWER HALF AS TO NUMBER OF WORDS TO THE PHRASE-BOOK $\checkmark$

XVIII. ONE HALF THE PARAGRAPYS COMPARED TITH THE OTHER TIALF FOR MUMBER OF SENTENCES-BOOK I

XIX. ONE HALF THE PARAGRAPHS CONPARED TITH THE OTHER HALF FOR NUIEBER OF SENTENCES-BOOK IT 100

$\mathbf{x x}$

ONE HALF TIE PARAGRAPIS OOMPARED OTHER FIALF FOR HUTHER OF SENTTENCES-BOOK III

101

XXI. ONE HALF THE PARAGRAPHS OOUPARED WITH THE OTHER HAIF POR WUIBER OF BENTENCES-BOOK IV 102

XXII. ONE HALF THE PARAGRAPHS COMPARED WITH THR OTHER HALF FOR NUIBER OF SENTENCES-BOOK $\vee 103$

XXIII. ONE HALF THE PARAGRAPHS COMPARED WITH PHE OTHER UALF FOR NUMBRR OF PIRASB8-BOOK 1 IO5

XXIV. OHE HALF THE PARAGRAPHS COMPARED WITH THE OTHER HALF FOR NUMBER OF PURASES-3OOK II 106

XXV. ONE HALF THE PARAGRAFHS COUPARED WT TH THE OTHER HALF FOR NUMBER OF PHRASES-BOOK III

XXVI. ONE HALF TLE PARAGRAPHS OOPPARED "IITH THE OTHER HALF FOR WUIBER OF PHRASES-BOOK IV 108

XXVII. ONE HALF THE PARAGRAPHS COMPARED WITH THE OTHER HALF FOR NUUBER OF PHRASES-BOOK $V$

XXVIII. ONE HALF THE PARAGRAPHS COMPARED WI TH THE OTHER HAIT FOR SCORES-BOOK I

XXIX. ONE HALF THE PARAGRAPIS COMPARED WITH THE OTHER HALF FOF SCORES-BOOK II

XXX. ONZ HALF THE PARAGRAPHS COMPARED WITH THE OTHAR HALF FOR SCORES-BOOK IIT 
XXXI. ONE HALF TUE PARAGRAPIS COMPARED WITH THE ORHIR HALE FOR 3CORES-BOOK IV

XXXII, ONE HALF THE PARAGRAPHS COUPARED MTTH TIE OTHSR HALF FOR SCORES-BOOK V

XXXIII. SURHARY OF TIE ODD PARAGRAPHS COUPARED WI TII THE IVEN PARAGRAPUS TO DETERMTNE WIBATR TIE TPO HALVES ARE REPRESENTATIVE OF BOOK I

XXXIV. SUMMARY OF THR ODD PARACRAPHS COMPARED WITH THE BVEN PARAGRAPISS TO DETERHINE FIITTHER THE TWO HALVES ARE REPRESENTATIVE OF BOOK II

XXXV. SUREARY OF THE ODD PARAGRAPIS COAPARED WITH THE EVEN PARAGRAPHS TO DETERMANE WHETHZ THE TWO HALVES ARE REPRESENTATIVE OF BOOK III

XXXVI. SUISARY OT TIE ODD PARAGRAPHS COMPARED MITU WHE EVEN PARAGRAPHS TO DETERITIE WHETHER TIE TNO MALVES ARE REPRESENTATIVE OF BOOK IV

XXXVII. SUIRARY OF THE ODD PARAORAPHS COAPARED WITH THE EVEN PARAGRAPHS TO DETERUINE THETHER THE TIO HALVES ARE REPRSGENTATIVE OF BOOK $\mathrm{V}$

121

XXXVII. VOCABULARY ANALYSIS BI PARAGRAPHS FOR BOOK I, BUROPE TIE IFOTHER OF AEERICA, BY HORNE-BUOKS

XXXIX. VOCABULARY ANALYSIS BY PARAGRAPIIS FOR BOOK II, OUR NATION'S IERRITAGE, BY IALLECK-FMANT

XL.

VOCABULARY ANALYSTS BY PARAGRAPHS FOR BOOK III, THE OLD FORLD BEGINHINGS OF A BERICA, BY KBLTY

XLI.

VOCABULART ANALYSIS BY PARAGRAPIS FOR BOOK IV, THE ATESI CAN PEOPIE AND THEIR OLD WORLD ANCESTORS, BY VOLLINTINE

XLII. VOCABULARY ANALYSIS BY PARAGRAPHS FOR BOOK $V$, ELEZENTARY ,ORLD HISTORY, BY BEAPD-BACLEY 
XLIII, VOCABULARY ANALTSIS OF REPRESENTATIVE SSLECTIONS FROU FIVE SIXTH GRADE HI STORY BOOKS USED FOR UIST ORY COMFREHENSI ON TESTS

131

XIIV. DIFPERENCES BETWEEN THE FIVE HSTONY BOOKS FOR TIE PER CENT OF MORDS BEYOND 6047

134

XLV.

STARIOATCAL ANALYSIS OF THE PER CENT OF WORDS BEYOND AFREQUENCY VALUE OF 6047 FOR FIVE SUPPLEMENTARY HISTORY BOOKS

XLVI. SENTENCE AND PHRAGE ANALYBIS OF SELECTIONS COMPRISING TEST MATERIAL FHOU BOOK I

XLVII. SENTENCE AND PIMASE AIALYSIB OF SBLECTIONS COUPRIBINE TEST RATERIAL PROE BOOK II

XVIII. SEWPENGE AND PHRASE ANALTSIS OF SELECTIONS COMPRISITG TEST MATERIAL FHOM BOOK III

XLIX. SENTEHCE AND PIRASE ANALYSIS OF BELECTIONS COMPRISING TEST 期 TERIIAL FROA BOOK IV

L. SENTENCE AND PHLASE ANALYSIS OF SELRCTIONS COMPLISING TEST MATERIAL FROM BOOK V

LI. GTATSTICAL ANALTSIS OF THE SENTENCELEHCTH (WORDS), PHRASE-LENOTH (WORDS),AND THE NUMBRH OF PHRASES TO THE SENTENCE FOR TIE SEVENTEIN SELECTIONS FROM THE FIVE SIXTH GRADE HISTORY BOOKS -BOOKS I AND II 146

LII. STATI 3TICAL ANALXIS OF THE SENTENCELENGTH (WORDS), PIRASE-TENGTH (WORDS), AND TIE NUMBER OF PILASE3 TO TIE SENTENCE FOR THS GEVENTERN SELECTIONS FROU TIE FIVE SIXTH GRADB HISTORY BOOKS -BOOKS III AND IV 147

LIII. STATIBTICAL ANALYSIS OF THE SEHTENCELENGTH (TORDS), PHRASE-LENGTH (WORDS), AND THE NUMBER OF PIIRASES TO THE SENTENCE FOR THE BEVENTEEN SELECTIONS FAON THE FIVE SIXTH GRAOE IIISTORY BOOKS -BOOK V

LIV. BOOKS RANKED AS TO SENTENGE-LENGTH (MORDS) 150

LV. STATISTICAL ANALYSI OR TIE DIFFEREHCE BETWEIN UEANS AND $3 T$ ANDARD DEVIATI ONS FOR SENTENCE-LZNOTH OF THE BELECTIONS FROU THE PIVE HISTORY BOOKS 
LVI.

STATI BTICAL ANAL YSIS OF TIE NULBER OF SENTEACES TO TIE PARAGRAPH OF THE SEVENTEEN SELECTONS FROA THE FIV SIXTH GRADE HISTORY BOOKS

LVII. STATISTICAL ANALYSIS OF THE DIFFERECE BETISEN IEAIS AND STANDARD DBVIATIONS FOR TIE NU YHBER OF SENTEMCES TO THE PARAGRAPH OF THE SEVENTEBN TELECTIONS FROE THE FIVE HISTORY BOOKS

LVIII. BOOK? RANKED AS TO NURBER OF SENTENCES $T$ TIE PARACRAPH

LIX. STATISTICAL ANALYBS OF TIE DIFPERENCSS BETTEZN IAEANS AID 3TANDARD DEVIATIONS FOR NUPBER OF TORDS TO TIZ PIRASE OF THE SELECTIONS FROU TIE FIVE HISTORY BOOKS

LX. BCOKS RAMKED AS TO PTRASE-LENGTH (MORDS) 158

LXI. STATISTICAL ANALXSIS OF THE NUUBRE OF PHRASES TO THE PARAGRAPI OF TIE SEVENTEEN BDLECTIONS FROM THE FIVE SIXTI GRADE HISTORY BOORS

LXII. STATISTICAL AWALYSIS OF TE DIFFEREUCES BETWEEN TUE NUIBBR OF PHRASES TO THE PARAGRAPH OF THE SEVENTEEN SELECTIONS FROM THE FIVE HISTORY BOOKS

LXIII. BOOKS RANED FON NUMBER OF PURASES TO THE PARAGRAPH

LXIV. STATISTICAL ANALYSIS OF TIE DIFTERENCES BETWEEN HEAHS AND STANDARO DEVIATIONS FOR NUUBER OF PIRASES TO THE SBNTENCE OF THE SELECTIONS FROH TIE FTVE HISTORY BOKS

$L X V$. BOOKS RAMKDD FOR THE AVRRAGE NULERR OT PHRASES TO THE SENTEINCE

LXVI. BOOKS RANKED AS TO VOCABULARY, SENTTNCELENGTH (HORDS), PHRASES-LENGTH (MORDS). FHRABRS TO TIR SBNTAHCE, NULBER OF SENTENCES TO THE PARAGRAPH, AND NUMBER OF PARASES TO THE PARAGRAFH

LXVII. BOOKS RAHKED AS TO TIE AVERAGE RATINGS ON VOCABULARY, SENTENCE-LENGTH (WORDS), PHRASELENGTH (WORDS), PHRASES TO THE SENTENCE SENTENCES TO TIE PARAGRAPH, AND NUMBER ÓF MHRASES TO THE PARAGRAPH 
LXVIII. AQE AND GRADE NORIS FROA THE METROPOLITAN ACHI EVEILENT TESTS, AVERAGE NULBER OF PUPILS IN EACH AGE AND GRADE CATEGORY, AVBRAGE SCORE, PER CENT OF ACCURACY, AND TIER TO COMPLETE IIISTORY COMPREHENSION TESTSGROUP I

LXIX. AGE AND GRADE NORAS FROM THE METROPOLITAN ACHIEVEUENT TEST3, AVBRAGE NUMBER OF PUPILS IN EACH ACE AND GRADR CATEGORT, AVBRAGE 3CORE, PER CENT OP ACCURACY, AND TIUE TO COLPLETE HISTORY COUPREITENSION TESTS - GROUP II

LXX. AGE AND GRADE NORMS FROM THE HETROPOLITAN ACHI EVEMENT TSSTS, AVERAGE NUIBER OF POFILS IN EACH AGE AND GRADE CATEGORY, AVERAGE SGORE, PER CENT OF ACCURACY, AND TI HE TO COUFLETE HISTORY COMPREHENSI ON TESTS - GROUP III

LXXI. AGE AND GRADE NORMS FRON TUE HETROPOLITAN ACHIEVELENT TESTS, AVSRAGE NU:BER OF PUPILS IN BACH AGE AND GRADE CATEGORY, AVERAGE SCORE, PER CENT OF ACCURACY, AND TIHE TO COMPLETR HISTORY COUPREHENSI ON TESTSGROUP IV

LXXII. AGE AND GRA NORUS FROK THE UETROPOLITAN ACHI EVERENT TSBTS, AVERACT HUMBER OF PUPILS IN BAGH AGE AND GRADE CATEGORY, AVERAGR SCORE, PER CENT OF ACCURACY, AND TIME TO COMPLETE III STORY COMPREIENSION TESTS - GROUP V

LXXIII. READING AGE, PER CENT OF ACCURACY ON IISTOAY ACHIEVEUENT TESTS, AVERAGE TIUE IN COMPREHENSI ON OF TEST AND AGE LGRADE NORM OF METROPOLITAN ACHIEVEUENT TESTS

LXXIV. DATA OF TIE FIVE GROUPS EQUATED FOR CHRONOLOGICAL AGE

LXXY. STATISTICAL ANALYSIS OF THE DIFE SRENGES BETWEEN IRANS AND STANDARD DEVIATIONS FOR THE FIVE GROUPS RQUATED ON CHRONOLOGICAL AGE

LXXVI. DATA OF THE FIVE GROUPS EQUATED FOR UENTAL AGE

LXXVII. STATISTICAL ANALYSIS OF THE DIFEERENCES BETTEEN MEANS AND STANDARD DEVIATIONS FOR THE FIVE GROUPS EQUATED ON MENTAL AGE 
LXXVIII. DATA OF THE FIVE GROUPS EQUATED FOR READING AGE

LXXIX. 3TATISTICAL ANALYSIS OF THE DIFFERENGES BETTEEN UEANS AND STANDARD DEVIATIONS FOR THE FIVE GROUP 3 EQUATED ON READIMG AGE

LXXX. DATA FOR NUMBSR OF CORIECT RESPONSES TO COUPAEIENSION QUESTIONS ON THE FIVE BOOKS THEN THE PUPILS ART BQUATED FOR CIRONOLOGICAL AGE

LXXXI. STATISTICAL ANALYSIS OF TUE DIFFERENCES BETWEEN UEANS AND 3TANDARD DEVIATIONS FOR COARRRHENSION WITH CHRONOLOGTCAL AGE CONBTANT

LXXXII. MEANS NUMBER OF CORRECT RESPONSES AND HEAH NUEBER OF MINUTES TO FINI SH TIR TESTS WHEN THE GROUPS VIERE EQUATED ON CHRONOLOGI GAL AGE

LXXXIII. STATISTICAL ANALXSIS OF THE DIFFERENCES BETWERN ZEANS AND STANDARD DEVIATIONS FOR TIUE SCORES WTTH CHRONOLOGICAL AGE CONSTANT 207

LXXXIV. DATA TOR THE NUMBER OF CORRECT RESPONSES TO THE COMPREHENSION QUESTIOHS ON THE FIVE BOOKS WHEN THE PUPILS ARE BQUATED FOR JENTAL AGE

LXXXV. STATISTICAL AMALYSIS OF THE DIFFERENCES BETVESN IEANS AND STANDARD DEVIATIONS OF SCORES IN COMPREHENSION TITH IENTAL AGE CONSTANT

LXXXVI. MEAN NU:BBER ON CORMBCT RESPONSES AND MEAN NUABER OF. NINUTES REQUIRED TO FIHISH THE TESTS WHEN THE GROUPS WRRE EQUATED ON WENTAL AGE

LXXXVII. STATISTICAL ANALYSIS OF THE DIFTERENCES BETVERN EEANS AND 3TANDARD DEVIATIONS FOR TIME TO COMPLETE THE TESTS WITH HENTAL AGE CONSTANT

LXXXVIII. MEAN NUWBER OF GORRECT RESPONSES AND MEAN NUABER OF IINUTES TO FINISH THE TESTS THEN THE GROUPS WERE BQUATED ON MENTAL AGE

LXXXIX. DATA FON THE NUHBER OF CORRECT RESPONSES TO TIE COUPREHEUSION QUESTIONS ON THE FIVE BOOKS THEN THE PUPIIS ARE EQUATED FOR READIUG AGE 
$\mathrm{xC}$.

STATISTICAL ANALYSIS OF THE DIFTEREACES

BETTESN MEANS AND STANDARD DEVIATIONS OF SCORES TN COMPREHENSION WI TH READIMG AGE CONGTANT

XCI. STATISTICAL ANALYSIS OF THE DIFFEREMGES BETVEEN IBANS AND STANDARD DEVI ATIONS FOR TIIE TO COUPREIEND THE TESTS WITH READING AGR CONSTANT

XCII. BOOK RAMIED AS TO IEAN PERFORMANOE ON TIE CORPR HENSION TESTS TIEN THE GROUPS TERE EQUATED FOR CHRONOLOGICAL AGE, BEHTAL AGE, AND READING AGR

221

XCIII. STGNIFTCANT DIFPLRENCES IN COMPREHENSION OF THE BOOKS WIEN TIE GROUPS WERE EQUATED FOR CHRONOLOGICAL AGE, MENTAL AGE, AND READING AGE

APPRIDIX A-

I TO $v$ BASIC DATA FOR ALL PUPILS USED IN TIE STUDY, SHOWING GHRONOLOGI GAL AGE, WBNTAL AGE QUOTIBNTS, READING ACE QUOTIENTS FROM THE METROPOLITAN ACHIEVELENT TESTS, SCORE ON HISTORY COMPREHENSION TESTS, AND TIIXE TO COMPLETE HI 3TORY COUPRRHENSION TESTS

VI TO $X$ SUMYARY OF INITIAL DATA FOR THE FIVE GROUFS ZQUATED AS TO AGB, SHOFING THE COHPREHEUSION SCORES AND TILE OF COMPLETING TESTS

$X I$ TO XV SUMMARY OF IUITIAL DATA FOR TIR FIVE GROUPS EQUATED AS TO MENTAL AGR, SHONING THB COUPREILNSION SCORES AND TIIE OF COMPLETING TESTS

XVI TO XX SUUMARY OF INITIAL DATA FOR TIE FIVE GROOFS EQUATED AS TO READING AGE, SHOIING THE CORPREIUNSTON SCORES AND TIUE OF CONPLETING TESTS 
INTRODUCTI ON 
In the experience of the author the problen of what a child can loarn frova textbook has arisen over and orer agaln. Casual observation and conference with other teacherg have led to the concluel on that many books. excellent as to content and course of study requirements, are practically worthless to the child beoause he cannot read ther with a wefleient degras of understanding either to hold his interest or to juatify the expenditure of time required to waster the asagnmont.

\section{TES THOSLEA}

The problem of this study is to analyze five supplementary history books comonly usod in the public sohools of Loularille. Kentichy, wh respect to:

1. Dlficulty of pocabulary in terms of trequency of uaage according to Thorndike's classificati on

2. Word-length of sentences and plrases, counting five letters to the word

3. Deteralnation of the degree of accuracy with whin 272 sixth-A pupils from five of these sehools read then

\section{Thorndike, E. L., he Teacher'g iord Book of Ton} thougand iords. 1923, p.111. 
4. Determination of the suitabi11ty of the five history books for the pupils who read thom, as judgod by analysis of vocabulary and by phraseand sentence-1ength and by tasts of comprehension as related to age and grade norms

The following 1 tve history books were ohosen for the study because the writer ished to know Gheir ralue as teaching tools in the grade in wich she teaches:

I. Europe the Nother of Americe. by Charles F. Horne and OIfve Buaks. New York, Charles E: Merri11 Company, 1930.

II. Our Nationts Heritaze, by Reuben Fost Halleck and Julletse Pranta. Now Yorle, Anert can Book Compeny, 1932.

III. The 01d Vor 10 Beglaninge of Anerios. by uary C. KeIty. Nen York, GInn and Company, 1932.

IV. The Amerioan People and Their old Torld Anoestors. by Grace Vollintine. Nen York, Ginn and Company, 1930.

V. The Elementary Morld HLstorx. by Charles A. Beard and TIII New Fork, The Hacmillan Company, 1932.

The ariter took from ach of these books seventeen paragraphs which, in the opinion of $f$ our sixth grade teachers, one fifth grade teacher and one ungraded elass teacher, were representative of the book as whole. Every vord of the seventeen selections from each book tas tabulated as to frequency of usage acoording to Thorndike's Clasalfioation ${ }^{2}$ for:

7., Thorndike. E. L., The Teacher's Word Book of Ten Thouaand Words. 1923, p.iil 
1. The rilliclassifleation of words from 1,000 to 10,000

2. The number of words beyond 10,000

3. The nuaber of words beyond 5047 3047 being taken as the number of rords nornal twe Ive-year-old child should know-.- 3ee page 4.

For the sentence- and phrade-length analyals, pirase and sentences wora counted $f$ or ach paragraph, as ware the number of phrases to the sentence. Bach plarase and mentance was then analyzad as to the number of word a it contalned, counting five lattera to the word to insure unif ormity of agtinate.

To deteraine the degree of accuracy with thich the pupll comprahended these representative alections, compretension tosts were bulit on the seventoen paragraphe for each book. To rake the tats, four major ldaas wero ohosan from ach paragraph, ${ }^{3}$ gaeh ldak being tested with maltiple choloe quation.

These to of comprehension mere given to five different group of $\mathrm{gixth}$ grate pup123, (one test to each group), by their homeroom teachers under the direction of the sehool prinelpals. Flve different groups were used to avold practio affects.

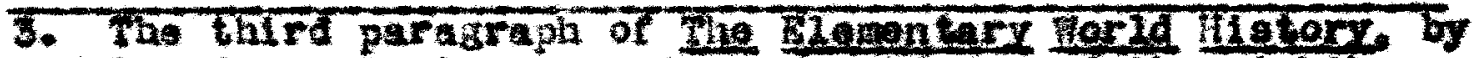
Beard and Bagley has six wa jor Ideas and the lighth paragraph of the old vorld Beglnninge of Aneriog, by

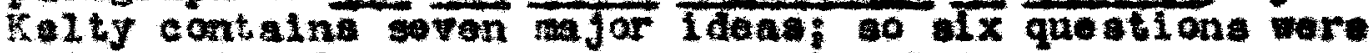
made on the forreer and eeven on the lattor. 
From the chlldren tested flve groups were ohosen so as to be comparablo in chronological age, mental age. and reading age as explained in Chapter III. The averages of these five comparable groups on the comprehension tests are considered indicative of the difflculties of the flve history bookg examined-- See Chapter III.

To determine the relative value of the five history books for use in grade 6.8 (upper sixth) by pup11s twelve years and fire months 0ld, three methods were ueed:

1. Vocabulary analysis of all words occurring in the seleations both before and beyond 6047 (twelf th year) 5 level

2. Analysis of phrase- and sentencelength as to number in paragraph and number of words to the phrase and sentence

3. A degree of accuracy on the history comprehensi on tests of 75 per cent or better ${ }^{6}$

A summary of tho findings in previous studies on rocabulary, phrase- and sentence-length and comprehension

4. $12-5$ age and 6.8 grade is the age $-g r a d e$ norm given for the upper sixth grade by the Hetropoliten Achievement Tecte, Intermediate Battery - Partial: Form A, For Grades 4, 5 and 6. Edited by Jacob S. Orleans, 1932.

5. 6000 words are given by Louis 1 . Terman as the average for a twe 1ve-year-old child. The Heasurement of Inte 11isence, p. 226, 1926. 6047 is ubed in this study because it is a riliclassification boundary stablished by the Thorndike rocabulary soale.

6. Ayer, Adelaide " Some Difficulties in Elementary Sohool History. Teachers College Contributions to Education. No. 2IL, New York, Teaohers College, Columbia Univeraity, $1926, p .32$. 
is Elven under "Li terature" in Chapter II. "gxperimantal and Analytical Procedures" are glven in Chapter III. The "Data" and the "3tatistloal Procedures" employed are given in Chapters IV, V, and VI. Chapter VII is a sumary and interpretation of the ontire stady - Iiterature, vocabulary and sentence-and-phrase analyos, and experiment. An atteapt is agde to ralate the findings to the al tuation as 1t actually exists in the sixth grades of the Loulsvilie Fublie sobools. Original data are given in Appand $1 \times$ A. Coples of the tosta uad in tho study are Given in Append $\times$ B. 
CHAPTER II

LI TERATURE OF THE FI ILD

I. VOSABULARY IN RPADING

A. Sumbary of Vocabulary Investigations

During the last two decades a great number and variety of investigations have beon made in the interest of the scientifle study of education. These investigations have embraced practioally all aspects of eduoational work and not a few of them have been ooncerned with the subject of vocabulary.

Many word studies have been made. These studies were primarily for the purpose of developing ilsta of words that were found in usage. In general they have been developed by the method of analyzing written correspondence and printed naterials.

One type of study is lilustrated by those that have been made in the interest of developing spelling scales. Probably the most important of these studies are Ayres' A Measuring Scale of Ability in Bpeliling. Ashbaugh's Iome Spelling Soale and Buokingham s Spolling Ability. Its Measurement and Distribution.

Some other investigations have developed rocabulary tests by which they have eatimated the roeabularies of individuals, (the number of pords an individual can define). Doran did considerable work of this kind which was 
LI 
reported in 1907. 1 kirkpatrick and Burch have al so developed tests for estivating the rocabularles of pupils." Hoat of these studies are bassd apon itst of 100 words chosen at randon tros a dotionary. The test conalats in finding the pereentage of the wards in the chosen 11 st which can be definod. It a pupil can define 50 per cent of the words on the list, it is aseamed that he can detine 50 per cant of all words in the dictionary from which the vorde are taken.

othar invastigations have been developing the roeabularies that aro peouliar to cartaln aubjocts of the curriculuw. Thaphrey has recently o capleted a stady in whioh he investigated the rocabulary of toxtbooks in the fleld of Junl or high school athenatica. 3 Another uroup of studtes which are concarned wh the spectal vocabularies of comon cohool subjects are those developed by Preasey in which she 11 ated the toolunioal words that appeared in the toxtbooks in each subject and osthatiad the comparative iraportance in the aubjeot of each word thus appoaring. 4 Thls list may bo

1. Doran, B. ". "A Study of Vookilary." Padagozloa Selinarr, Volume 14, 1907, pp* 401-38.

2. Thrkpatriok and Bur oh, voabulary Tests a taagurea of 3ohool Zfflelen $\mathrm{y}$ " Behool and Boglety, Volume $\mathrm{z}$, 1915, pp. n13-18.

3. Humplirey, 2., The jateratancion of the Vocebulary of

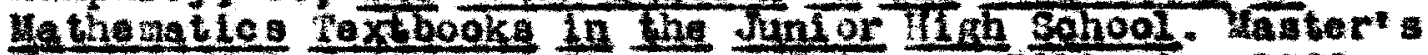
Thesis, University of Chicago, Chicago, IIIInols, 1926.

4. Fressey, J. C.. The Datermination of the Technical Vocabulary of the School Subjectr." Sohool and Soelesx. Volua 20, 1914, pp. 91-96. 
used as atandard for maasuring the technical vocabulary of speoifle lementary school gubjeota.

Powers reports a study in which a number of textbooks In science were rated by the number of vords found which were not in the Teacher's Hord Book. 5 The books in this case were read completely and all words not in the Teacher's Ford Book. With their frequencies, were testod. This procedure produced comparable data estimating the relative difficulty of the vooabuiaries of the respective books.

A de balled study, some Diflcultieg in Elementarx School History, by Adelaide I. Ayer, has been made on the basia of a study of 23 if th grade history textbooks widely used in the United States. ${ }^{6}$ Hi as Ayer has listed the language difficultes in these books under the followng hade: 7

I. Passages involving technical terminology essential at some point in the school course to the comprehension of history

II. Dif liault words and expresslons not essential to the comprehension of hiatory

1. Hiscellaneous technical terms

2. Concepts of a geographical nature

3. General abstract terms

4. Literary omblili shments

5. Long involved sentences

6. Abstract thought

5. Powers, S. R., "The Vocabularies of HIgh Sohool Bolence Textbooks." Teachers College Record. Volume 25, 1925, pp. 368-82

6. Ajer. Adelalde 1. . Some Diffloulties in Elementarr 3ohogl History. Tachers college Contributions to Education, No. 212, Wor Fork. Teacher College, Columbla tinivereity,1926

7. Ibld.; Chapter II. 
Two of lliss Ayer's concluaions are: 8

1. The results of these tests show an astonishing inability on the part of both 11 th and seventh grade pupils to comprehend $f$ if th grade hlstory paragraphs.

2. "The results of the study of the correspondence between reading comprehensi on in general and comprehenst on of fifth grade history paragraphs containing typical diffleulties ind cate that the content of moh of the widely used fifth grade histories is oufficiently diffloult for high achool use."

Host of these diffleulties in the elementary school hi story involve pocabulary that is uncommon in the experience of the child. Had H1ss Ayer made and given a vocabulary test incorporating the diffloult words of the paragraphs whioh she uged in the comprehension tests, she would probably have found even greater inablilty to understand the meaning of the words.

In the Rating of the Vocabulary of $31 x$ American History Textboeks for the Serenth and Elghth Gradeg." Wiss $H$. S. Salth attempted to rate the genoral dificulty of vocabulary of each textbook and to find what progressive diffleulty of vocabulary there was within each of the texts. Bach textbook was ranked on the basls of the three ratinge:

1. Words not $f$ ound in the Teacher's Word Book

8. Ayer, Adelalde H. Bome Difflaultied in Blenentary Sahool Hiatory. Teachera Collog Contributions to Education, No.212, NeW York, Teachers College, Columbla University, 1926 , pp. $48-49$.

9. Smi th, $H$. S.. The Rating of the Voabulary of Six Americen Hetary Textbooks For the Beventh and Elghth Grades. Uastert 
2. Words not found in the first 2500 nords of the Word Book

3. Words in the Pregsey list of

The first two standards used are rellable measures of general vocabulary difflculty. The Pressey 11 st of technical and unfamillar words is not a list of words selected on the basis of frequencies, and is not considered rellable to use as standard to rate general difficulty of vocabulary. It, however, should be a falr measure of the technlcal vocabulary of history textbooks.

Gate s" A Reading Vocabulary for the Primary Grades ${ }^{11}$ gives a list of 1500 words which have been selected as sul table $f$ or use in all $f$ orms of reading material in grades flrst, second, and third. The peroentage of words that are not found in the Gates primary list which oocur in the reading content of textbooks measures the increasing burden of the vocabulary of a text beyond the primary grades. Experlants have shown that difficulties wth arithmetic problems, for example, are sometimes due not to lack of ability in arithmetic, but to unfamiliarity with the words w1 th which the problem is expressed. This indicates that words beyond the pritnary vocabulary are introduced in too great a number and with too little frequency to give the

10. Pressey, J. C., "Determination of the Technical Vocabulary of School Subjeots." School and Socletr. Volume 20, 1924, pp. 91-96.

11. Gates, Arthur I., "The Construction of a Reading Vocabulary for the Primary Grades." Teachers Gollege Record. Volume 27, 1926, pp. 46-5i. 
child an opportunity to becone thoroughly aequalnted with the new rocabulary of a higher grade. The Gates primary 11 st may be used as a standard to measure the gradation of pocabulary of textbooks for the intermedlate grades. ${ }^{12}$

The most elaborate and comprehensive study is Thorndike's The Teacher's Word Book. ${ }^{13}$ It contalns a 11st of 10,000 words which were 1 ound to occur most erequently in forty-one different sources of printed material. He has also incorporated the 11 sts derived by other investigators. The Teacher's 嘿ord Book probably 1s, the best standard for measuring the rocabulary of elementary grade textbooks.

The foregoing brief accounts of some of the rocabulary Investigations and of Miss Ayer*s study of Diffioulties in Elementary Sehool Higtory should give the reader general notion of what investigators in this fleld have been dolng.

\section{COMPREHBHBION IN READIMG}

\section{A. Yocabulary-Sentence-Burden and Comprehengion}

Roading of the simplest type has been defined as getting maning frow the printed page. No definition could be more sleading than this. One does not got meaning

12. Gatos, Arthur I., The Constructi on of heading Vocabulary for the Prinary Grades." Tesohers College Record, Volume 27,1926, po. 46-51.

13. Thorndike, E. L., the Teacherts tord Book of Ten Thousand Words. 1923 . 
from the printed page. In the first place there is no weaning on the page; only symbols of meaning are there. Furthermore, printed symbols do not give meaning to the reader; they merely stimulate meaningful mental activity. This he does by recalling, manipulating, and combining cencepts that the printed syrabols stand for. If the reader does not possess the concept or aning that the printed symbol represents, it is utterly impossible for hitn to read the symbol and achlere meaning, even though he may laarn to recognize the symbol mechanically in - ither visual or auditory form. Thus it is clear that the real and fundamental source of meaning in reading llos in the coneepts that the reader takes with him to the printed page. ${ }^{24}$ It is equally elear that reading of the simplest type may be defined as the making of oorrect meaning under the stimulation of printed symbols.

Thi dpoint of viem emphasized the signifioance of better underatanding of the nature of the reading vocabulary. In the first place, it is clear than an individual's real reading vocabulary is composed only of those words with which he $1 \mathrm{~s}$ abie to make meaning when he comes in contact with their printed symbols. Some words will be useful in all their different weanings;

14. This polnt of vio was first emplastzed by Dr. Ernest Horn, College of Education, State University of Iowa, Iowa City, Iowa. A detailod and soholarly treatment of the problem is presented in lathods of Instruation in the social Studies. Nev rork. Charles Scribner's Sons, 1937. 
others lil be known in connection with only one or two of their several meanings. Host certainly no word form is part of an individual's reading rocabulary then ho doe not understand the particular meaning for which it stands in a given setting, even though he is able to pronounce or to rocognize it visually as something he has seen before. A child's reading vocabulary is made up of the meanings wilch he has acquired and to which he has attached closely the appropriate printed symbols.

The reading vocabulary required of the school ohlld at every grade level is much greater than one is oomonly led to believe. It is often as gamed that the more frequently a word recurs, the more likely are the children to comprehend its meaning. Upon this supposition alone many teachers base their choice of readers. That there may be real obstao ies to comprehenstion in recurring ${ }^{15}$ words is shom in the evaluation of fourteen primary readers by Uisa Ethel L. Fennoll. 16

She points out that a probable reason for diffloulty in the comprehension of reading lies in the fact that textbook writers, in their eff ort to famlliarlze children with certain words, have provided numerous recurrences of these words but have disregarded the fact that

15. "Reourring words" means "words of identical $f$ or $m^{\text {" }}$ 16. Fennell, Ethel L., "Recurring Fords and Their Relation to Difficulty in Comprehension." Blementary School Journal, Volume 29, 1928, pp, 42-53. 
frequently the words recur with entirely different meaninge.

In all, we found 222 different words that reourred at least onoe in the readers. For these 222 mords, a total of 842 meanings were discovered, making, on the average, 3.79 dfferent interpretations for each word in the entire set of fourteen readers.

If each word recurred with only two or three meanings, the problem would be sufficientily great, but in reality it is eren more complex. More than half the recurring worde, 122 of the 222, have two different meanings to comprehend; 38 require three different interpretations; and 21 , four interpretations. The rest of the recurring words, howerer, have greater number of meanings. 7 have five moanings; 4 have ight; 6 havo nlne; and 3 have ten. "By" roquirea twolve different interpretations; "good, "fourtoen; "out," fourteen; "to," seventeen; "at" and "of," twenty each; "for," twenty-one; "In." twenty; "on," twenty-three; and "up." twenty-four. The extension of the "primary sense" of prepositions has produced a mutiplicity of neanings that have been used profusely, as indicated, in primary reading. Stmilar findings are reportad by Devey ${ }^{17}$ and Uhl. 18

17. Devey, Joseph C.. A Case Study of Regalng Gomprohenalon Diffloulties in Ainerican History. Abstract of Doctor' Dissertation, Coliege of Education, State Unirersity of Iowa, Iowa City, I owa, 1934.

18. Uhl, "vilifs L." "The Vaterials of Reading." Thirtzgixth yaarbook of the National Society for the Study of Education, Part I, 1937. Chapter VII. 
Pressey, ${ }^{19}$ in a atudy of rocabularles of videly ubed histories, finds 542 technical words considered the "essentla1" vocabulary of the subject, and 503 "accessory" vocabulary, in all, 1045 mords wich are tecinical or umusual and which would not frequentiy be met, if at all, outside textbooks. The importance of knowing these words is strassed by pressay, who says: The failure to know this or that word is not an isolated or unimportant condition, but is prinarily evidence of failure to conprehend the idea represented by the word."

In this connection Uh1 ${ }^{20}$ writes: "One of the surest ways by which the technical vocabulary of a given subject oan be controlled and bought clearly to the reader's attention is to make sure that the rords used in the books on that subject do not get out of hand. If rocabularies are selected for power. this can not take place. The words that ohildren learn will be usable in many different connections. Thus the books in science. geography, history, readine and health will support one another."

Uhl believes that suitable books for the middle grades should be written in words that are $\mathrm{knom}$ to be in the rocabulary of the children of the grades in whion they are used. Our vocabulary specialists, he finds, have been forgetful of the fact that, truly considered, a

19. Pressey, L.C., "The Determination of the Technical Vacabulartes of school Subjects." Sahool and Soclety, Volume 20, 1914, pp. 91-96.

20. Uhl, 罚illis L., "The Haterials of Reading." Thirtysixth Yearbook of the National society for the Study of Education, Part I, 1937, pp. 222-227. 
word is not a form but neanting. "thether or not the word 'blaze' may be used in a fourth-grade book depends on tho meaning you athach to it. If the "blaze" of a fire is ant, you are sate. If the 'blaze' on a troe made ith a hatahot to indicate the trail is meant, you w11 of the $\mathrm{r}$ have to heach the rord or ase abstitute. A at aple word 1 lke 'get" may have a dozen or more meanIngs, not just one. Or 16 may have degrees or levele of meaning. The word 'bank' mans 'a bullding." "a place to depont noney." "a place to borrow mone" "an organization that pays interast." 'a place to keep jewalry." 'a placs through whel to pay bills," and a thodiun of Inancial axohange"."

In Hiss Lenna $\mathrm{z}$. Swook $\mathrm{g}^{21}$ atudy she attempts to deterwine the relative difliculty of the reading content of Interadiate grade history textbooks on the basia of sentance diffleulty. She asuras that the length of a sentenoe ther hinders or aids comprehention.

To deteraine the ther wis be true, alatory reading test was ade in two forma. Fiqe paragraphs of reading mattor wer alooted, one from each of the five aixthgrade textbojks consilared in the atudy. The length of the ancenees ranged from 10 to 37 word with an avarage 21. 3mock, Lenna E.. I Study of Intarmedlate Grade hatory

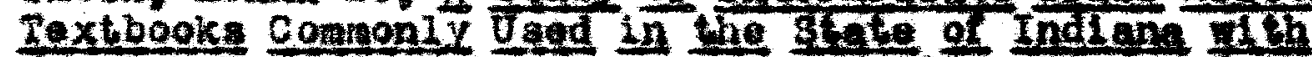
Special ReTerence to the Felative Dir Touities of the

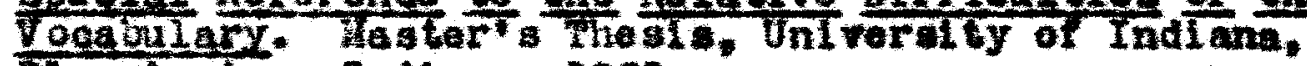
Bloomington. Inviana, 1929. 
length of 24.4 words. The paragraphs as originaliy taken fron the books were arranged in Form I of the test. Four queations were given after aach paragraph to test the oomprehension. They were to be answered with one word.

The two forms, (original and rewritton sentences). were given to 104 fif th grade alilidren of the publio sohools of Bloomington. Indiana. It was so arranged that every other pupil, 52 in all, took Form I and the other 52 took Form II. All the ohildren ware given the to complete the text.

The Sangren-Hoody Reading Test was given to these same chlldren. It rakes a comparison of the ohild's achievement in various types of silent reading activity. The coefficients of reliability are somethat higher for this tost than those generally reported for standardized educational tests:

$\begin{array}{ll}\text { Fora I } & 11 \\ \text { form II } & .82 \\ \text { Sangren-woody Teat } & .75 \\ & .95\end{array}$

The hedian and thoan Scores radu by each group on the History Reading Test and on the Sangren-Foody Reading Pegt are given below: Hi atory-Reading Sangren-Woodr

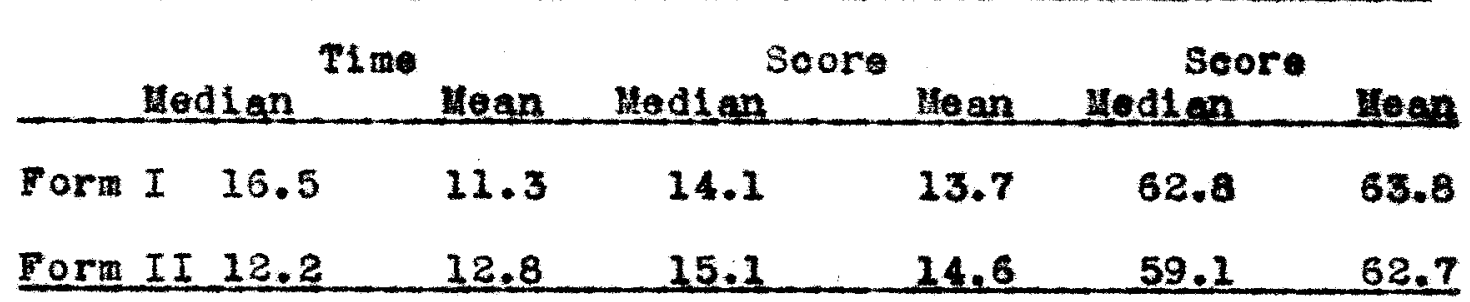


The two groups of fifth grade ohildren to whow the History Reguing Test was given made about equal achievement scores in varlous types of silent reading activities. The group that took form I of the test made an average soore of 63.8 for the Bangren-翟oody Test, while the group that took From II had an average soore of 62.7 for the same test. Miss Brock conoludes: "The results of the testing to measure the effect of the length of sentence upon comprehension did not show any signiflcant differenoe in favor of the shorter sentence . . We cannot, as yot, by any authority, say wat the average length of the gentence of the reading matter of intermediate grade textbookg should be."

Gates, however, 22 does find that sentence 1 mpl1fication is important, and fiom ${ }^{23}$ states that to read effectiveiy a child should:

1. "Be able to interpret the pasaage properly, phraeing accurately, recosnlzing periods and punctuation marks. He should have sufficient "eye-volce span" to permit expressive appreciative infleotion.

2. He should be able to comprehend the text, its vocabulary and sentenoe struoture."

22. Gate 3. Arthur I., The Improvement of Reading. $\triangle$ Program of Diamostic and Remedial Methode. 1935, p.668.

23. Horn, Ernest. The Objeotives of Reading as a Guide to Reinedial and Prophylaotio Work." Yearbook No, $\mathbf{z}$, Departraent of Blementary Sohool Prinelpels National Educational As ociation, 1923, p. 204 . 
Wh1le Ayer ${ }^{24} 1$ sts among the difficulties in comprehension of history. "long involved sentences." as an example she gives: "In the year that Lonls XIV was crowned there was born at Mouen, an old town to the northrest of Parls, a boy who was to place the French lag in the Isisisalppl Valley. The name of this child was Robert Chevalier sieur de la Salle." She says, however, that such sentences were common to only a few of the fit th grade histories examined.

B. Studies Which Show the Etreot of Vocabulary upon Comprehension

Johnson, 35 in his study of the polyayllablo worda in standard reading tests makes the following concluai ons:

1. "The results of this experiment showed tiat most of the puplis made high scores in the shortword tast wille many of those taking the Iong-word tegt rade low scores. The wide difference in seores between these two equated groups ind cates that the monosyllabic word test as strikingly less diffioul than the polyayliabic word test.

2. The pereentage of polysyllablo words in the firat five successive Broups of 500 words in the Thorndike 11st inoreases ith oach group, Indicating that as the words decrease in irequenoy of $u$ as, they increase in length.

24. Ayer, Adelalde H., Some Dillaulties in Elementary History. Teachers College Contributions to Education, No. 212. Hen York, Teachars College, Columble University, 1926, p. 10.

25. Johnson, $G$. R., "An objeotive Method of Determining Reading Difficulty." Journal of Rduoational Research, Volume 21,1930 , pp. 284-5. 


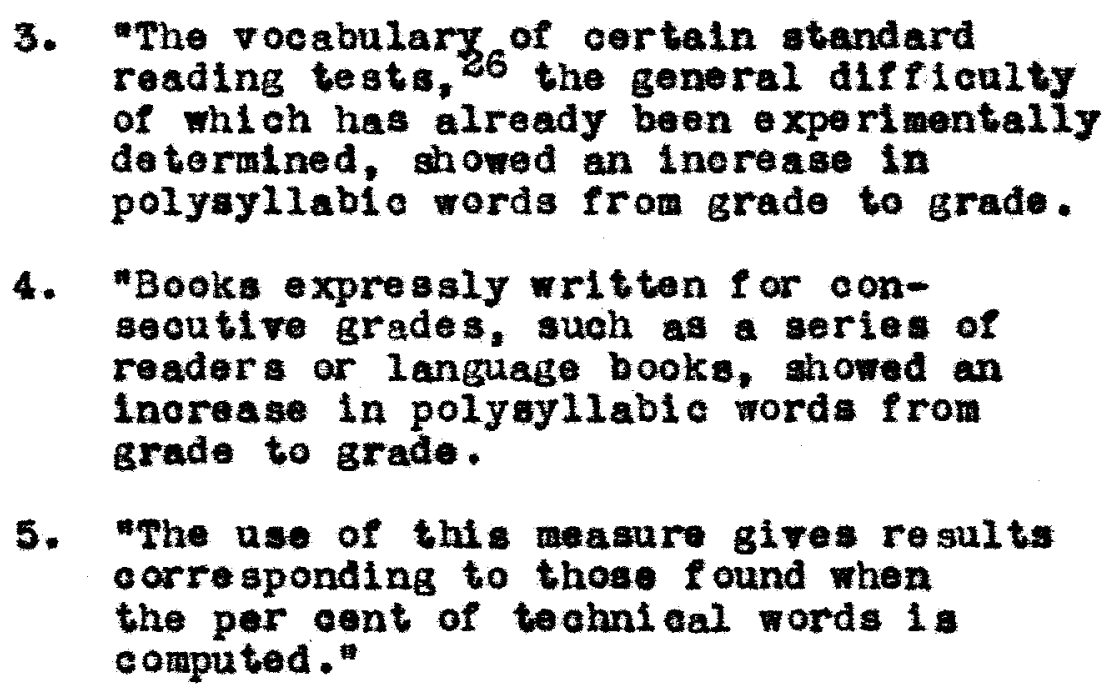

The count of tochnical words, based on the Pressey Teahnical Vocabulary Lists. gives the same relative rating to books as does the count of polysyllable words. This may be shown by atudy of four history books, the results of which are given below:

Text Iistory

A
B
C
D
Per Cent Polysyllable
34.5
34.5
32.8
31.8

Por Cent Technical

$$
\begin{array}{r}
12.2 \\
7.7 \\
7.5 \\
6.0
\end{array}
$$

The thod employed in Cutright' $\mathrm{s}^{27}$ study is similar to that employed by Ayer. ${ }^{28}$ The technique involves the development of objective tests. One test, Test A, was

26. Gray's Sllent Readlng Test, Gray's Oral Regding Teal. Thipple's High Sehool and College Test. FhorndikeMo Gall Reading Tests and stenford Beading Tests.

27. Cutright, Prudenoe, Halvorson, George, and Brueckner, J. L., "A Study of One Pactor in the Grade Placement of Reading Materials. " Hiementary Bohool Journal. Volume 29, 1928, pp. 284-95.

28. Ayer, Adelalde Home Diffioulties in Elementary School History. Teachers College Contributions to Idueation, Ko. 212. New York, Teachera College, Columbia University, 1926, pp. 16-30. 
designed to determine the vocabulary difflculties encountered in Heidi; a second test, Test $B$, was designed to meagure the oxtent to which pupils underatood sections of the book. The tests showed that such words as "ollmax," "primitive," and "passionately" were beyond the comprehensi on of all the 230 fourth-grade pupils who took the test, and such words as "gummoned," "as gure," "expectations," and "pursued" were understood by fewer than 26 per cent of the pupils, irrespective of grade.

85 per cent, in Test $B$ requires eighth-grade raading ability

75 per oent, seventh-grade reading ablilty

70 per sent, sixth-grade reading ablilty

65 per cent, fifth-grade reading ability

50 per cent, Pourth-grade reading ability

Ayer 29 states that sohool practice seldow consider a score much below 75 per cent of the posstble number of correct responses to be satisfactory. In her testa, ("A Determination of the Extent of Reading Difficulties in Fif th Grade Histories"), a child"s G reading soore on the Thorndike-tocall Reading Seale, which corresponds to 75 per cent of answers correct on the original paragraphs is for the ighth month of the tenth grade.

It requirod reading ability equal to the last half of the tenth grade as represented by the thorndilce-MeCall Reading Seale to get 75 per cent of the answars correct on the original paragraphs of Ayer's history test.

29. Ayor. Adelaido H., Sone Dlffloultiea in Elomentary School History. Teachers College Contributi one to Bduoation, Ho. 212, New York, Teachers College, Columbia Unitersity, 1926, pp. 32-33. 
It was found that a $G$ score of 7.7 or reading ablitity equal to the seventh wonth of the seventh grade as represented by the Thorndike-10Call Reading Soale was necessary to got 75 per cent of the almplified anmers corract.

It was found that to answer correctly on the original 11th-grade hletory paragraphs, in the origtnal form. ablilty as following was necessary.

Grade Ability

$$
6.5
$$$$
7.5
$$$$
10.8
$$

Per Cent of Correct Angwera

25

50

75

Ayer also found that when she had simpliffed the paragraphs, it required reading ability about two grados lower than that required to answer the same questions on the original paragraphs.

Mary C. Burch, ${ }^{30}$ belleving that the satisfaction which a book brings to 1 ts reader is of primary inportane in the assignment of reading materials, asks the question: what are those factors involved in reading a book which determine the satisfyingness of the act?" She answers the que ation by saying that the diffioulty encountered in oomprehending the matter, or the amount of the matter which is understood is a very important determiner of satisfaction.

\begin{tabular}{|c|c|}
\hline & 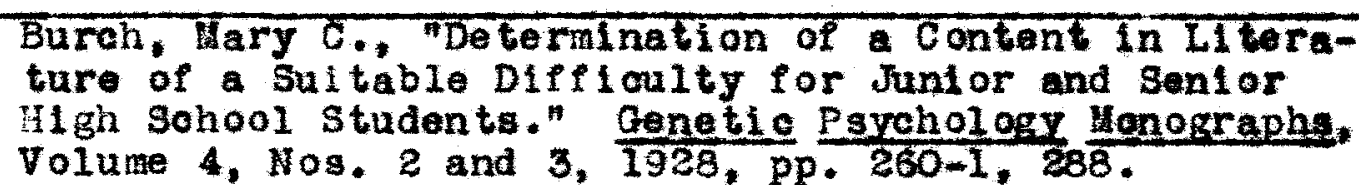 \\
\hline
\end{tabular}


A book may be so hard that any attempt to read 1 : bringa only annoyanos, or, on the other hand, so aasy that it fails to stimulate that mental actirity wich produces satisfaction. There is a range, she states, in diffioulty of roading material within whoh one reads with satisfaction, and the chances are small that ono would go above or below this range th resulting pleasure. This range she defines as between 59.40 per cent and 89.85 per cont, with median of 75.25. The following facts were also revealed by her test scores:

1. The means of contiguous grades are close together.

2. The range of ablitity in ach grads 1 great.

3. The amount of overlappling of each grade on the other is largo, in some cases all but complete.

4. Huch of the present course of study in high sohools $1 \mathrm{~s}$ wited to tho ability of about 25 per cont of the meubers of each class.

An intersating check on Burch's study is a thesis by T. 访. Irion, ${ }^{31}$ Coroprehension Difficulties of Ninth Grade Students in the Study of Literature. Irion tested the comprohenston ability of ninth-grade students by means of four long selections from literaturs. The reading comprehension of these students for these four selections ranges from 34.4 per cent to 52.7 .

31. Irion, T. W., Comprehension Difficulties of Hinth Grade students in the Study of Literature. Teachers College Contributions to Eduoation, 10. 189. New York, Teachors College, Columbla University, 1926. 
From his study on 11 teraturo comprehenaton he dreme the following conalusions, (among others):

1. "Literary comprehension of ninthgrade puplls can be falrly accurately measurad.

2. "Comprehension Varieg with Ilterary types-poetry types being most diptioult.

3. Mord knowledge is a very algniflcant ltom in reading comprehension.

4. Literary omprehenal ons are a better Index than are feeling reactions."

fathews, 32 in his study to determine the degree of comprehenaion at arious age and grade levelo for representative sampling of material of a certain course of study, found that the comprehension of fourth-grade puplis on these roading materials, (episodes, descriptione, expositions, newspaper articles). range from about 8 to 45 per cent. On the average, they made a sore of approximately 25 per cent on the trenty-tive samples of these materials. On the other types of materlals thelr degre of comprehension is less, being 10 per cent on graphs, 11 per cent on maps, 14 per cent on 11 me 1 ines and 16 per cent on pictograms.

The median comprehenst on of the twelf th grade puplis on these reading waterlala is about 85 per cent. Their 32. Mathens, C. O., The Grade Placement of Curriculum Haterials in the Social Studies. Teachers College Contributions to Education, No. 241. New York, Teachers College, Columbla University. 1926, pp.34-5. 
median comprehension scores on the other types of materiale are as follows:

$$
\begin{aligned}
& \text { Haps - - - - - - - - - } 74 \text { per oent } \\
& \text { Plotograms - - - - - - } 74 \text { per cent } \\
& \text { Time IInes - }-\ldots+\ldots-\ldots \text { - } 67 \text { per cent } \\
& \text { Graphs - - - - - - - } 55 \text { per oent }
\end{aligned}
$$

The averaze degree of comprehensi on for the reading materials is higher, grade for grade and age for age, than 1t 1 for any of the other types of material. The lowegt average degree of comprehension 1 on graphs, (bar. circular, and line graphs combined), with maps iylng betwe on these two types. If these three seta of measures vare plotted on the same ordinates, the three ines would not oross at any point.

Thls study, however, presenta no evidence as to the factors which make materials diffioult.

Dewey, 33 in attempting to answer the question:

mhy do ohllaren at an elght-grade level comprohend as thay do?" made reading wolections from elghteen textbooka In Amerlaan History in current use in the publio schools. He used the following oritoria in selecting the materlals:

$$
\begin{aligned}
& \text { 1. Paragraphs or other unt to that } \\
& \text { contain meanings or concepts that } \\
& \text { require oareful. inferential thinking } \\
& \text { 2. Selections that disouss toplca in } \\
& \text { political, economic and social history }
\end{aligned}
$$

33. Dewey. Joseph C. A Cage Study of Reading Comprobenal oa Difliculties in American History. Abstract of Doc6or's Dissertation. Graduate college of the state university of Iowa, Iowa Clty, Iowa, 1931, p. 27. 
3. Selections that lend themselves to several mothods of testing

4. Selections that are short enough to permit exhaustive testing and long enough to permi a reasonablo continalty of discussion

Two types of researoh techni ques were used:

1. Penoil and paper tests and

2. Oral interriers

Each pupil of the latter group was given written tests and oral interviews on two different reading selections. The Individual interview were recorded by the Iowa Oral Language Recording Hachine in order to seoure a oomplete and accurate rocord of overything said by the investigator and by the children. In place of questions, he used a serios of plotures as a measure of comprehension. He $f$ ound that:

1. "Elghth-grade ohilaren are not always consi stent in reaponding to different types of tests or identical or similar ldeas which are beling tested.

2. "Children sometimes chose the correct picture in a plature-cholce test, but demonstrated in the oral interviow that thoy had inadequate or errone ou concepts of what the picture represented."

In this, Dewey concludes that the correct choice of plotures pertaining to certain types of context glves very Iittle assurance of adequate understanding of that context.

3. On the mole the pupils made a larger percentage of correct responses on the oral interview than on the written testa. 
4. "The fact that the words in which any Elven meanling 1 s expressed are found in we 11 -knom vocabulary 11 at is no guarantee thet the meaning will bo gained by children.

5. "zoo wo confidenoe ahould not be placed in verbal response as eridence of understanding or in rerbal presentation as an adequate method of teaching.

6. The high percentage of correct responses on factual teat 1 tems as compared with the emall number of correct anawers on Infarence test items is open to two interpro tations.

a. "It may be that these responses to the factual test 1 tems, although oorrect, are no indlcation of proper undertanding of the facts, and that a part of the inablilty to make inferences is due to the inadequate understanding of the facta upon which the inferenees are based.

b. "It may be that the ablilty to make Inferences ia itself so poorly developed in elghth-grade chlldren that. even though understanding, inferences are not asily made."

A o ritical study of the detalled answers on the written tests and even nore particularly in the oral interviews leads Devey to belleve that both of these $11 \mathrm{mitations}$ operated.

\footnotetext{
7. "Children of ten are unable to locate in the reading content the axat sentence upon which their test responses are based."
}

This may be explained in some cases by the fact that the responses are based on knowledgo gained before reading the content and partiy upon inability of children to understand 
the test questions in the light of the context. Another posaible roason may be the unreliability of the invest1gator a judgment in deciding mat sentenoes were to be considered as atisfactory responses, relative to the proof lor any given response.

$$
\begin{aligned}
& \text { 8. "Chilaren in the elghth grade do not } \\
& \text { seen to posess sufficlent back- } \\
& \text { grounds in the fle lds of history. } \\
& \text { civics, economics or geography, or } \\
& \text { even in general xperience to under- } \\
& \text { atand and interprot in this investi- }
\end{aligned}
$$

Or it may be, as suggested by Ayer, that children simply camnot interpret abstract subjects such as: "tariff." "inance," "political parties," "lections," "banks," and "slavery controversies."

Karl F. Nolte ${ }^{34}$ a2so uses such devices as plotures. graphs, map and the peraonal interview to determine children's vocabulary difficulties and the concepta they obtain from their reading at a axth grade level.

In the piotorlal tests, pupl1s wore anked to Indicate those plctures which best represented a particular word, group of words, aentence or thought in the reading selection. One or more pictures placed in each group was illustrative of the correct concept, whereas the others were alther wrong or required discrimination on the part of 34. Nolte, KarI F."SImplifloation of Vocabulary and Comprehensi on in Reading." Elementary Bnglish Revien, Volume 14, No. 4, 1937, pp. 119-124. 
pupils. The waps were used princlpally to indicate the location of places and areas referred to in the reading selections. A bar graph was also used as an aid in determinlng the extont to which pupils understood the dosoription and the comparative size of areas referred to In the article.

Inodlately following the plotoriel and map tests. pupile were interviewed in order to seoure additional Information as to their comprehension of the materials fust read. By this method, ooncepts and rooabulary difficulties were disclased which could not be obtalned through an objective test.

The purpose of the reading comprehenalon testa was to determine the difference between pupils' ability to read almplified material and to read material in its orlglnal form.

Five different comparisons were made on each of the three reading selections. Three of the ve were for the purpose of comparing results of the original material with those of the material rewritten acoording to Thorndike 35 anu Ogden ${ }^{36}$ vocabularies respectively, and for determining the advantage, if any, of one simplifled form orer the other. 35. Thorndike. E. L. A Teacher. Iord Book of the Imenbx Thou and ords ound Lost Trequentiy and Widely in General Reading for children and Young People. 1938.

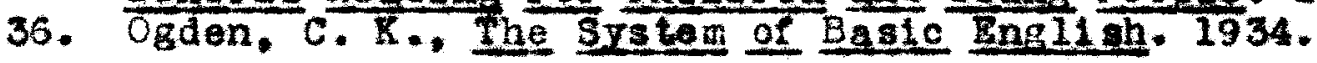


The other two comparisons were to determine whether differences might result from using simplified questions. The following findings ware revealed through the study:

1. Taken in their entirety there were no statistically signifleant differenoes between comprehensi on of selections read in the original form and those read with reduoed vocabularies.

2. "Signiflcant and meaningful differences were found on few single test items which ind loated wherein a number of vocabulary changes either facilitated or hindered pupil's comprehension of material read.

3. "In so far as results of a fow al ngle test iteras disclosed, there were more signif lcant differences found in favor of the Ogden Sinpilfication than the Thorndike. On the test as a whole, there were no signiflcant differences in favor of eithar. However, the differences that did exist were greater in $f^{2}$ aror of the ogden rocabulary, but not being significant, they were no doubt due to chance.

4. "The Ogden rocabulary, with 1 ts $11 \mathrm{mlth}$ soope and its extre ilmitation of verbe, rereals instances wherein substitutions necessitated a divergenoe from standard English uage, making the language oumbersone at ti a.

5. There were instances wherain other - lements ware made more diffioult by necessarily replaoing a single word wh a phrase or a group of words.

6. "Staying within the $11 \mathrm{mits}$ of Thorndike"s first 2500 words (recommended as being sultable for the fourth grade) did not, In the main. facilitato understanding to the sixth-grade level. 
7. Mictorlal tests and personal interviews revealed numerous vocabulary difficulties and croneous oonoepte which were most frequentiy amons pupils in the lowar percentiles.

8. "ictorial teats and peraonal interviews disclosed eonfusione that wero caused by certain words and phrases having several possible connotations."

Result from this investigation indicate that keeping other elementa constant, the simplification of rocabulary does not materially facilitate pup11s* understanding of material read. Only in a 11 mited number of ingtances did the substitution of a known word for an unknown word ald pup12s* comprehenston. On the other hand, there were times when other structural elements were made more diffioult. The other factors that retard comprehengion are tlus and place. An inadequate sense of time, as pointed out by Fesley 37 and Dewey, 38 is a factor that operates more in the sockal studies tian in other subjects. The pupil may have little realization of even shart periods of time, and years inay be for him as mere astronomioal vagaries. Until a rather definlte time sense has developed, the pupil oannot appreciate cause and effect or sequential rebtionshipe. The process of grouth in developing a time sense, however, 18 fairly well understood. It seong to grow with age an

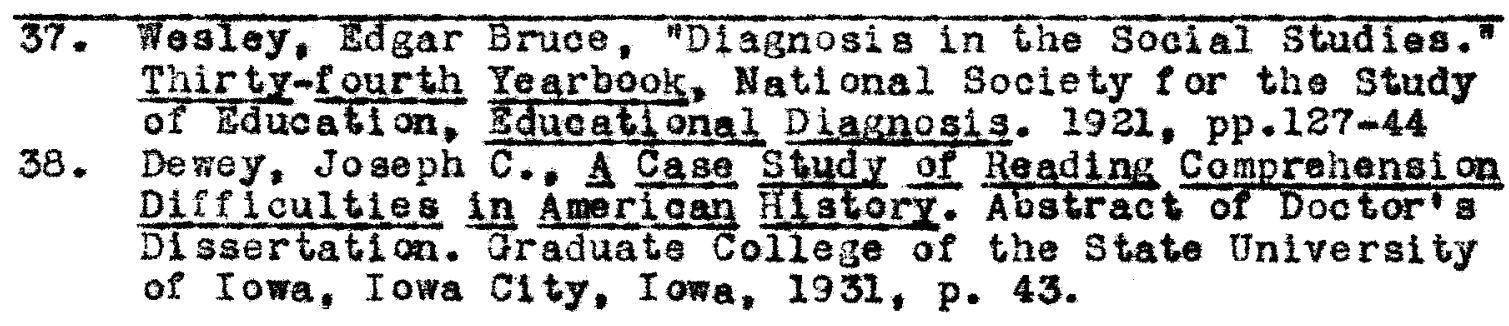


ahom by Lary Sturt ${ }^{39}$ and Hary $0 . \mathrm{Kalty}$ * 10

Equal in 1mportance to the time sense is that of place, which involves directions, areas and all kinds of geographic masurements. Soolal actualitios occur at sone time and in some place. The two factor seento be not only alds in understanding and remembering actualitios but also integral parts of them. This probably means in practice that the puplla mas know some geography in order to understand social actualities, and without the necessary skil1s in reading maps, tables and charts they cannot acqulre the necessary geographic knowledge. Children are apparentiy satisfied with the crudegt notions of diraction, space, and messurements. As long as they have vague senge of place they are likely to have only - vague realization of what occurred in a designated place.

C. The Rete and Depth of Conprehension of $\operatorname{sen} \tan \operatorname{seg}$.

It is cugtomary to distingulah two featurea of comprohonsion during reading, as pointod out by Gates: ${ }^{4}$ 1. The power or deptiz of oomprehension and 2. Rate of speed of oomprehension

39. Stuart, Hary, The Psychology of Time. London, 1925 40. Kelty. Mary C., Tine Mxpressi ons comprenended by Chlidren of the Elementary School Elementary

41. Gates, Arthur I. The Psychology of Reading and Speling whis special Refarence to plsability. Teachers College contributions to ducation, No.129. New York, Teachers College, Columbia University, 1922, p. 53 . 
That this distinction is valid has been demonstrated before. 42 although tests made on the two ablilties show, in general, high correlations. In particular cases, bowever, wide differences, which are of utmost importance for diagnostic work, have been found.

In testing for rate and comprehenaion, Gates used the Thorndike-HoCall Heading Seale Alphe 2 and the Thorndike-Hocall Reading Scale, whioh givo the most ralid measure of power or depth of comprehension, and the Burgess Ficture Supplement Test. the Courtis Test. or one of several other teats for "rate of comprehension." The mean correlation between the composite of speed tests and the composite of comprehenstion tests is $\mathrm{hlgh}, 0.84 \neq 0.08$. This figure, Gates says, probably does not represent the real association of rate and depth of comprehension because it was found that nost of the tests which proposediy were measures of depth of comprehension were really measures of rate. The mean correlation of Thoradike-licCall with other tests is $0.46 \neq 0.18$ as compared with the mean $r$ of 0.66 w 0.12 between the Burgess and other tests. The an of the grade correlation between Burgegs and Thorndike-MaCall is approxinatoly 0.5 , which represents, in Gate's opinion, approximately the actual association of rate and depth of comprehension.

42. Tates, Arthur I., "An Experinental and Statistical Study of Reading Tests." Journal of Educational Psychology. (Oatober, November, December, 1921). 
Gates states further that a rate of reading (grade III) as 1 ow as one word per seoond does not seriously handicap the subject for this test. when slowness of reading is the main difficulty. For example one pupil in grade III who could scarcely read one word per second, obtained a sore -qual to the norm for grade XI, which shows that mere alowness of reading need not seriously influence achlevement in the test.

In regard to speed of reading Gray ${ }^{43}$ points out that records of progress show that speed continues to increase steadily during the middle grades. Because of the great importance attached to spoed of reading. puplis have of ten been urged to read very rapldiy without due consideration to amprehenat on. The fact should be remembered that puplis differ radically in their capacity to read rapidiy; also, that speed is influenced by the reader's purpose, his interest in the content, the difficulty of the material. his control over the mechanics of reading, and his capacity to interpret meanings roadily. Speed in silent reading has somewhat the sane position as word recognition in the realization of meaning. It has no value by 1 tself. It has value only when it is closely tjar to comprehensions.

43. Gray. WIIIam S., The Nature and Organization of Basic Instruetion in Reading." Thirty-sixth Yearbook of the National society for the Study of Education. Part I. 1937. Chapter IV. 


\section{Laek of Comprehension Leads to Verballian and over-potanex.}

"Progreas in the soolal atudio is dependent upon an adequate vocabulary," say Edgar Bruce nesley. 44 Next to the lack of experience, perhaps the most fundamental difficulty in the fleid is that assooiated with word difficulty. In faot, experiences themeelves, he polnte out, lose meh of their value and algnificance when they are "unticketed and unnamed." Conversation and writing would be impossible w thout the system of identification tag callad words. "Experience furni ahes the basis and the purposes of thinkIng, writing and talking. The inadequate rocabulary may be the result of the lack of experienoe. In el ther case an Inadequate understanding leads to the use of empty words, whioh are usually called 'verbalisms'."

That the presence of verbalians indieates unsatisfactory learning $1 \mathrm{~s}$ also pointed out by Ayer 45 and Dewey. 46 Then ohildren do not understand the assignment or recitation they Fesort ther to omissions or to repetitions verbatim of the words of the anthor rather than to ohance incorrect responses. Continued repetition confirms the error and increases the difficulty of correction.

44. Wesley. Edgar B., "Diagnosis In the Soclal studies." Thirty-1ourth Tearbook of the National Society for the Study of Education, Educational DLagnosis, 1935. pp.318-319.

45. Ayor, Adelalde H. Some Diflloulties in Elementary Sohoal History. Teachers college Contributions to Bducation. No. 212, Hew York, Teachers College, Columbia Univeraity, 1926, pp. 48-49.

46. Dewey, Joseph C., A Case Study of Reading Comprehanal on Diffioulties in American History. Abstract of Doctor's Dissertation. Graduate college of the State University of Iowa, Iowa City, Iowa, 1931, p. 48 . 
The detection of verbalism requires alertnoss and skill, for the pupil develops oonsiderable art in vain repetitions. mesley 47 sights the following verbalism in the closing words of the salute to the flag by a six-year-old boy. wesley, noticing the closing words sounded inexact, asked the boy to repeat the olosing phrase rery careiully. what the chlld actually said was, "and just as far off," instead of the phrase, "and justice for all." This amaing error is as aningful to the boy as "justice for all." Oft-repeated verbalisms come to have the sound of reality. and every teacher realizes that they have the vitality of error.

There are also a large number of chlidren who bluff at difflcult anings. Their favorite thod of guessing at what they do not understand is apparently to get oue from the general atmosphere of the paragraph and to respond in stereotyped patter such as: "He was a rery nice man," "I think the people were kind," "He was brave and helped his country," or "they re re an to people."

Over-potency of lement as a common cause of error is oridenced from the responses to test material. It is possible that most ohildren do not select, welgh, compare and organlze the elements of a paragraph in dotermining its meaning, but instead, they see only high spots, catch famillar and oonsplcuous elements here and there, and jump to conclusi ons. 47. Tesley. Rdgar B., "Diagnogia in the Social studies.7 Thirty-fourth Yearbook of the National Soclety for the Study of Education, Educational Diagnosis,1935, p. 319 . 
Henoe the explanation for the erequent lliustrations of over-potency of aldatabs thich lata ohtldren into mid. abaurd and ladioron atatoments. The nore diffleult the abjet astier. the moro praquant is this tondenoy to orerpotency as:

Original Eorm

Hare ho rentined for four jears durlns the storat debate wan tha f ate of the Uni on ang in the balance.
Gaildren's Mosponges ila stayed ouk in the gtora for four yeara. It was gtorar where he vas.

Thorndike's analysts of tha reading involved in reading - paragraph suararizas the above dificulties in conprehention when he says: Hnderstanding paragraph is like solving a problem in the natios. It conalsta in selockng the right - lements of tie situation and putting then together in the right ralation and also with the right anount of welight or lafluence of force for each. The nind is asanilod, as it were. by every word in the paragraph. It mat seleot, repross. sof ten, amphasiza, correiste and orizanize all under tho Influenes of tha right mental set or purpose or demand."

Asain the ane author says, in roferring to paragrapha In historg, chics and geography textbooks: "It appeara likely. therafora, that any chlidren fail in certain features of these subjects not because they have untarstood and remembered the facte and principles but have been unable to organize and wae then; not bacans they have understood then but have been

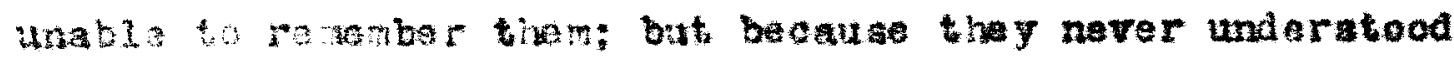
them... It 1 s not a sma11 or unworthy tagk to learn "ghat the book says"." 


\section{SULMARY OF TUE LITERATUNE OF THE FIELD}

It is apparent from the foregoing investigation that what a ch" a leams from the printed paze is not wholly dependent upon vocabulary-diffloulty and sentence-length and atructure. Eye-voice-span, intel11gence, perception, nature of the materiala, and emotional attitudes of the leamer undoubtediy play a atrong role in the learning process. But that $v$ oobulary-senterce-burden whon simplif led ral sea the compreheasion level two grades, and materials of instruction show a range of Iess than 25 to 50 per cent of the context In the grade in which they appear ahould cau ge weighty consideration to the curriculum taker. the textbook writer. and tho teacher.

Among the studies wilich shon the effect of rocabulary upon comprehension, are those of Johnson and Cutright. Johnson, in bis study of the polysyllabio words in standard reading tests found that most of the puplis made high soores in the short-word tests while nany of those taking the longword test made 1 ow scores. From this he ooncluded that the wide difference in scores between two equated groups ind cated that the monosyllablo word test was atrikingly $10 s$ difficht than the polyayllabic word test.

Cutright. In her tests designed to determine the vocabulary difficultes encountered in toldi, found that anch 
words as "olimax," "primitive," and "pasionately" rore beyond the comprehension of all the 230 fourth-grade papil wo took the tost. Applylng the reading gradas as determined by the Gates teat, it required seventh-grade reading ability to obtain a comprehension soore of 75 per cent, whle the fourth-grade children, to whom the book Heldi is assizned, understood only 50 per cent of what they read. Ayer found that to answer correctly on original Ifth-grade history paragraphs, it required ability oqual to the $6.5 \mathrm{grade}$ to earn a score of 25 per cont accuracy. She also found that wen she had simplifled the paragraphs, it required reading ability about two grades lower than that required to answer the same queations on the orlginal paragraph.

Subject matter that is too diffieult for the learner, that deals with abatractions, seneralizations and sumary notions brings annoyane to the learner. Such atimli weaken the connections of the learning procass and lead to Pailure. Thas retard the mental growti of the individual and of ten result in gerious cases of behavior maladjustment.

If it is the business of the school to seiect the environment that wil stimlate right attitudes, it rould seen that the curriculum which determines what shall be taught in the elementary school mist take cognizance of 
not only the phasea of randing, history, and goography whith are within the ohild" somprehanat on, but aleo of wajoet rattar that 1 moaningral, signifloant and wati:fylng to boys and girla to the degree that tha study wil laad into new flelds of invertigatione. This is but to ask the ourrloulua, the textbook, and the teachlng to be In haraony with the best educational theory. 
EXPEITENTAL AND ANALYTCAL PROCEDURS 
Because of the amareness of the Important part tilat supplementary books have in the school life of her pupils, the writer undertook during the year 1936-1937 certain investigations to determine how effectively sixth-A pupils of the Loulgville Public Schools learned from five history books.

\section{A. Bolection of Materials}

For the purpose of these investigations five supplementary history books in general use in the sixth-A grade were selected. These five books were chosen because the author desired to know the amount of history her pupils learned from these particular supplementary books since they were the ones assi gned to the grade she taught.

The books examl ned were:

I. Europe the Mother of Amerlca, by Charles T. Torne and Olive Bucks. Nes Tork, Charles E. Herrill Conpany, 1930 .

II. Our Nation's Heritage, by Reuben Post Halleck and Jullette Frantz. New York, American Book Company. 1931.

III. The old World Beginnings of America. by Mary C. Kelty. New York, Ginn and Company, 1932.

IV. The American People and Their old World Ancestors, by Grace Vollintine. Wew York, Cinn and Company, 1930. 
V. The Elementary por ld Ul story, by Charias A. Beard and TIllam C. Bagley. Jew York, The Hacmillan Company, 1932.

The author took from each of these books seventeen paragraphs which, in the experience of six toachera, were reprosentative of the books as tholes. These teachers mere: two sixth grade teachers, one fif th grade tancher. and one teacher of an angraced class from Calif ornia Bchool, and two sixth grade teachers from strother sehool. Paragraphs were elected which dealt with the aane topic in each of the books as. alown in rable I.I

\section{TABIRE I}

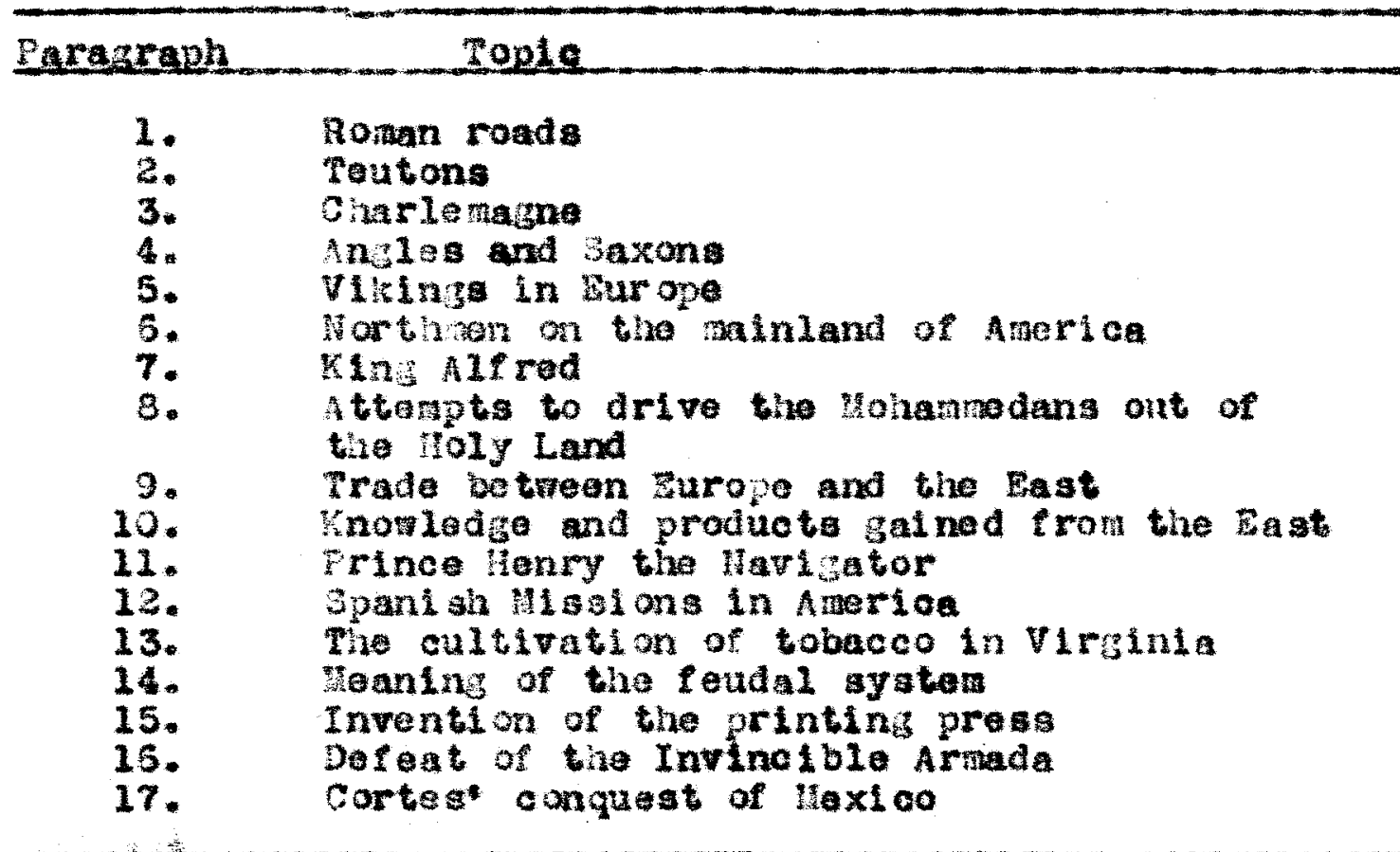

1. The Elezentary Torld Uiztory, by Beard and Bagley contalns no discusalon on tobacco so a paragraph on trade in sugar, ooffee, and spioes mas subetitutod. 
The above seventeen toples were selected because, in the optinion of the six teachers who examined the books, they met the following criteria:

1. Represented a wide range of subjects

2. Fere sufficiently independent of the context preceding and following that questions upon them could be answered without further knowledge of the subject matter of the book

3. Appeared to be representative in difficulty of the book from which they were taken.

4. Contalned four major ideas about which objective tests oould be built

B. Vocabulary Analysig

These selections ware analyzed first for the rocabulary in terms of e requency of usage according to Thorndike's Classification.?

Accordins to Thomdike's the thod of classifyling words, the more common a word is in general use the lower that word lies on hls soale of the 10,000 most common words. That is, his scale begins with the 500 most frequently used words and proceeds by steps of 500 up to 6047 , where he bogins to classify the words by stops of approximately 1000, up to 10,000. This study has combined the steps of 500 in the lower ranks and olassified all words by his

2. Thondike, E. L. The Teachers Word Book of Ten Thousand yords. $19 \overline{23}$, p. 11 i. 
milliclassification as shown in Table XLIII, page 131. Every word from the seventeen selections of each book was looked up on the Thorndike scale and placed according to Ito position on the scale. In the initial classiffcation the words $f$ or each paragraph were kept separate as they ware to be used later in the comparison of paragraphs. (Tables XXXVIII, XXXIX, XI, XII, and XLII pages 126 to 130). The aum of all words lying in each clasaification of the different books was then caloulated. From the sums of these classifioation-columns a grand total of all words in the seventeen paragraphs was made. This total was usad to find the per cent of words lying in the respective thousand th ranks; that is. the per cent of words lying in the f1rst 1000 , the second 1000, etc., to 10,000. All words beyond 10,000 were looked up in Thorndike's Book of Twenty Thousand Words ${ }^{3}$ and grouped into classification designated as "Beyond 10,000." Five mords from the pive books did not occur on either the 10,000 or the 20,000 11st. Since this was approximately one word in 1500 their value was probably negligible, but they were 1isted with the rorda "Beyond 10,000."

3. Thorndike, E. L., A Teacher's Word Book of Thenty Thousand words Found Tost Frequent1y and widely in General Reading for children and Toung People. 1932. 
As one phase of the study was to agcertain how - frectively children learn from a book whose vocabulary falls within a particular classification, all words boyond 6047 were counted for the selactions from aach book and the per cent of the whole number of words caloulated.

Gates ${ }^{4}$ used only the first 2500 words in the Thorndike Iist as one basis for the construction of a reading vocabulary list for the prirary grades, thus indicating that he considers that numer to be the upper vocabulary linit of the three grades. Thorndike 5 assigns credit numbers to each of the 10,000. The higher the credit or Index value of word, the more common 3 shat word in general use. Certainly Gates aocepted the irat 2500 as the easiest of the 10,000 and it nay be assumed from Thorndike's scale that the nore commonly a word is used, the easier is the word. Hence, the higher (toward 10,000) the word on the Thorndike Scale, the nore difflcult is the vocabulary of the book fron wilch the samples are taken.

From Gates 6 study it may be arbitrarily as sumed that by the time children reach the upper sixth grado

\footnotetext{
4. Gates, Arthur I., The Construction of a Reading Vocabulary for the Primary Grades." Teachers College Record, Volume $27,1926$.

5. Thorndike, E. L.. The Teachers word Book of Ten Thou sand Words. 1933, p.i11.

6. Gates, Arthur I.. "The Construction of a Reading Vocabulary for the Primary Grades." Teachers College Record, Volume $27,1926$.
} 
their corprehension of words is in excess of 2500. Neither Gates nor Thorndike gives the limit or range of vocabulary for the upper sixth grade. Terman, ${ }^{7}$ however, gives an approximation of 6000 as the rocabulary of a normal twelveyear-old child. The reading norns for this study were taken from the Metropolitan Tests ${ }^{8}$ since that battery of tests was used to determine the reading ages and grades for the sixth-A pupils used in this study.

At the time these tests were administered, all childran used in this experiment had been doing sixth-A (upper sixth grade) work for three months. Louisville has a ton-month term. The grade level for these subjects therefore was 6.8 when the tests were administered. The age for children in grade.6.8 is given as $12-5$ by the norms on the yetropolitan Achievement Tests. The milliclassification boundary for the six-thousandth vocabulary classification on the Thorndike Sealo is 6047, 806047 mas used as the upper limit of the nuraber of words fairly comprehensible to pupils in grade 6.8 .

Since the first 6047 words were considered reasonably well known by these pupils, the rest of the vords of this list may be considered as difficult for them. Thus all

7. Terman, L. M., The Measurenent of Intelligence. 1926. p. 226 .

8. We tropolitan Aohievement Tests. Intermediat BatteryPartial: Form A, For Grades 4, 5 and 6 . Bdited by Jacob S. Orleans, 1932. 
words begond 6047 were tabulated and their per cent estimated on the seventeen representative selection from the five history books.

C. Sentence and Phrase Analysis

The studies of Smock $^{9}$ and Ayer ${ }^{10}$ given under "Literature," Chapter II, pages 21 and 22, conaider sentencelength as a factor in the degree of comprehension with which a chlld reads history. Smook tests her subjects on original sentences from fourth, fifth and $3 i x$ th grade histories, and then for shortened sentences; Ayer uses tests ("A Determination of tha Extent of Reading Diffioulties in Fif th Grade Histories") for long involved sentences and then for simplified sentences. Nice's 11 case studies of sixteen chiliden from one year through the tenth year show that children of ten years use an average of 8.5 words to the sentence. An average of 144 adult sentencas showed this average of 8 words.

This study nakes no tests on origlnal nor simplified sentences, but analyzes the samplings from the five

\footnotetext{
9. Smock, Lenna S., A Study of Intermediate Textbooks Commonly Used in the State of Indlana with Special Reference to the Relative piff iculty of the Vocabulary and Length of Sentence. Master's Thesis, University Of Indiana, Bloomineton, Indiana, 1929.

10. Ayer, Adelaide $2 .$, Some Difficulties in Elementary School History. Teachers College Contributiong to Education, No. 2liz. Teachers College, Columbia University. New York, 1926, p. 10.

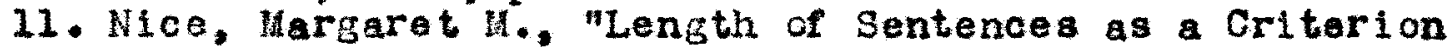
of a Child"s Progress in Speech." Journal of Educational Psychology, Volume 16, 1925, p. 370.
} 
hi atory books as to musiber of phrazos and santences to the paragraph and for tive total aeventeen paragraphs.

1. Bentonces and plirases to the paragraph

The nusber of sentences and the muber of pirases was tabulated for each of the selections separately so that paragrapis could be compared and statistloal pro-

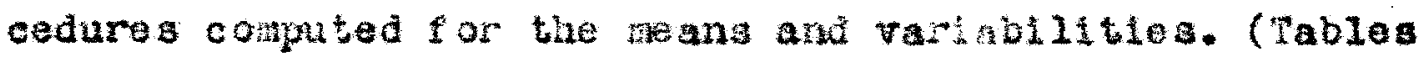
XLVI, XLVII, XIVIII, XIIX, L), pages 139 to 143.

Fron the number of sentences to the paragraph, nouns and standard doviations oproted for the saventeen paragraphs or the book. (Tabla LVI, pago 153).

The meana and standaru deviations were then compared that a dotaraination atight be made of the algnificanoe of any alferencs betweon then. (Tabla LVII. pago 154). The anta procedure was followed for the number of phrases to the paragraph and to the book. (Tablas LXI. and LXI. pages 159 to 160 ).

2. Sentence and Prase-1engith

As Ayer ${ }^{12}$ had found long inrolrad sentences a handicap to loarning by as auch as two yoars, the author analyzed the phrase-and aentance-lengti of the selections by counting tha nutaber of fords to the antence. To Insure a unlforaity of oount throughout the books, evory lottor in each word of the sentence was oounted and the

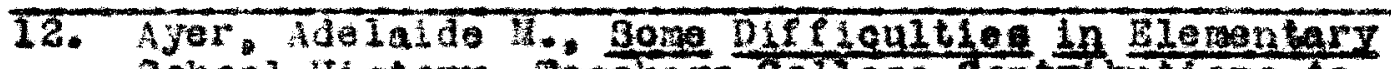
School Higtory. Teachers College Contributions to Education, No. 212. Teaohers Colloge, Colurbla Univoraity, War Tork, 1925, pp. 10,15. 
sure divided by flve. Thus the word count for ald selection is a unit word of ifve lettars.

The number of words to the sentence was tabulated for all seventuen paragraphe taken from each book.

The sua of the words, (flve letters to the word), was then divided by the number of sentences to the paragraph to get the average number of words to the aentence. Stat1stical calculations were made for the mans and varlabilities for each of the five booke. (Tables LI, LII, LIII. pages 146 *0 148 ).

The five books ware then compared for significance of differences botwen the ans and heasures of variablizty in number of words to tive sontence. (mable LV, page 152).

D. Mnalysis of iest Socres

Bnother phase of tha study mas to daterine the degreo of accuracy fis will the I72 alxth-s pupils read the severteen selectlona from each history book and anawered the questions of comprehension on then. Four major ldeas on which questions oculd be $g^{\frac{1}{2} \tan ^{13}}$ were laken from each of the paragrapis. The rour last questions were giton

13. The thra paragraph of 310 Elomentary iford Thetor by Beard and $B_{a j}$ ley has six major ldeas, and the

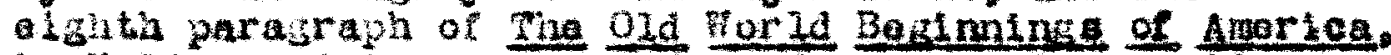
by Kelty containa seven for lfeas, so six queations wers ade on the former and seven on the latter. 
in the rultiple choice form, which required the pupil to mark one word or one phrase. (Appendix B)

The selections and their accompanying questions were given to one group of pupils in each of flve different sohools. All tests were administered by the home-room sixth-A teacher under the direction of the principal.

The instructions given bel ow were uniform for all groups:

Directions: 1. Read each parasraph.

3. Answer each question. Draw a ilne through the right answer as: "Louisvilie is a (a) house (b) etty (c) dog."

3. Work fast but ANBWRR EACI OUESTION CAREFULLY.

4. Put your name at the botton of ach page right now -- before you start to work.

Then every pupil understood what he was expected to do, the class as told to begin and the tarcher noted the time on the blackboard. The puplis were allowed all the time they wished in which to study the selections and answer the questions, both the selections and the questions being available throughou the entire period. As each pupil finished the test form, he raised his hand and the teacher wrote under the caption "Tine," at the head of the test, the number of minutes spent in completing the test. To cancel any practice effects the selections from Book I were given to the sixth-A group in school A; 
Book II to School B; Book III to School C; Book IV to School D; and Book $V$ to School E. ${ }^{14}$

The tests for the five graps of pupils were soored when every child had fint shed, civing a credit mark of one for every correct response. The scores for every child were then tabulated. (Tables I, II, III, IV, and $\nabla$, Appendix A). Score tiroughout the study neans pointscore or number of correct responses.

E. Equation of Groups

In order to determine wilch book was read with the greatest degree of accuracy, It was necesaary to equate the groups. In dealing with the se groups the results of the study are conoerned with the neans of the groups, not wit individual cilldren.

The groups were made up of 172 sixth-A pupils from five different schools. The author wishod to pair them on the traits of Chronological Age, Mental Age and Reading Age.

To equate the five eroups on the three variables, 1.e., Chronolojical Age, Hental Age, and Reading Age, pairing every child selected for the initial group with another child on the same variabies for each of the groups from the other four schools, reduced the population

14. Book I Albert S. Brandeis School
Book II Califormia School
Book III Gavin H. Cochran School
Book IV John C. Strother School
Book V Parkland Elementary School


of the groups to such snall numbers that group comparisons were not reasonably reliable.

The writer then equated the groups so that they would have approximately equivalent neams and variabilities. This basis of equating the groups also reduoed the numbers too Breatly for alequate accuracy.

Since the groups could not be equated on the three variabie basis, and as it was necessary to retain both the Chronological and Reading Age for later comparison for age and grade noras, Mocall' $3^{15}$ one variable method was usod. (Tables II, III, IV, Appendix A, and Tables VI to XX. Appendix A).

However, instead of pairlng the groups from the five different achools for a alnglo variable, groups were paired firgt on Ghronological Ase, holding sex constant; that is. for every boy used to make up the group for School A tiare was a matchirg boy in the groups of $3 \mathrm{chools}, B, C, D$ and $B$. A socond group was then made up on the variable of Mental Age, holding sex constant. In equating this group avery boy was matched wth a like boy in each of the other pour school groups.

For a third sroup the subjects from the ivo schools were matohed in the same manner on Reading Age.

15. McCal1, WIIIs C.. Hon to Experiment in Education. 1930. pp. 45, 57-8. 
When the pairing for the Chronological Age Group. Hental Age aroup and heading Ago Group was complote, oach group was made up of twenty-ons matohed subjects.

The method used in tils study differs from the wo thod of pairing subjects on three variables. When subjects are palred on three variables they are all the same children. In thi a experiment every oild used in the Chronological Age aroup is matched with a cinld of the ame sex and age for each of the groups from the five schools. Every ohlld in the Ifental Age Group is matched with like ohild in wah of the other school groups. Like procedures are used In the Reading Age Group until twenty-one children from School $A$ are palred with twanty-one like children in Schools $B, C, D$, and $B$. These subjects, however, are not siways the same subjects.

The group of pupils making up the twenty-one pairinga of the Chronological Age Group are not in all cases the same pupiIs used in equating the Mental Age Group and the Reading Age Group. Neither are the pupils used in the Mantal Age Group nor those in the Reading Age Group in all cases found in the other groups.

This method. though it necassitates the handling of fifteen sets of subjects, - five sets to each of the three groupings, - shows the relationship between comprehenst on and the other variables, by comparing chronological age, 
mental age, and reading age with the degree of acouraoy with which the group road the selections and answered the questions on then.

The flve pupil-zroups composine the Chronological Age Group vere arranged according to aje. Innediately to the sist of the ase colum were placed the scores of the pupils, and in a third colume the the taken to complete the test. (mables II, III, and IV, Append Ix A).

Statistical analysis mas then nade for the five pupilgroups naking up the Chronologlcal. Age Group, computing the means, standard deviations of the aistributions, probable errors of the distributions. probable errors of the means and atandard errors of the stardard deviations. (Table LXXIV. page 188)

The mans of the ilve groups were compared for differences betwean neans, probable arrors of the differences, and the differences divided by their probable arrors, that a determination might be made for any signifioance that existed between zroups. If a differonce alvided by its probable error was 3.00 or more, it vas considered simificant; if less, it was onsidered not slenificant. 15 (Table LXXV, page 190).

16. Link, H. C., "Tow many Interviews Are Wecessary for Results of a Certain Acouracy." Journel of Applied Psuchology, Volume 21, 1937, p. $\overline{5}$. 
If this ratio, (Diff./PE diff.) regulted in a quotiont anywhere approachlng 3.00, or signifleance, the Age Group was changed until the difference in age was negliglble. Standard deviations and their probable errors were employed In comparing variabilities of the flve Age Groups. If a diference between standard deviations was three or more tImes its probable error, the group, or groups, showing the signiflcant difference was changed until all five groups showed approximately equivalent means and variabilitios. (Table LXXV, page 190).

When the age grouplnga were satisfactory, the degree of comprehension with which the selections wore read, was analyzed by the aame measures of central tendency and dispersion as were the ages; no ohange, of course, being made in seores after they nere once set up according to that partioular pupil used in the final form of the Age Group. All differences of a significant value were marked "Ye." All those that were not signiflcant wero marked "No." (Tables LXXX, page 203 and LXXXI, page 204).

Like statistical procedures were omployed for time taken to read the selections and answer the questions to determine the significance of differences in the time the groups apent in completing the History Comprehension Tegts and also in the scores they made on the test. (Table LXXXIII, page 208). 
The Lental Age Group and the Reading Age Group were sot up and statistically analyzod $f$ or differeneas as was the Chronological Age Group. They wer also analyzed for differences in degree of oomprehenal on and tim taken to complete the text. (Tables LXXXIV to XCI, pages mo to 220).

F. Analysis of Date to Determine the Degree to mich the Semples Were Gemregentative of tho Book Tran thich they wore taken.

The data as analyzed ghow the stgnif loance of differences botwoen the roprosentative samplings of the five history books in:

1. Vocabulary range: a. Per cont of word beyond 6047 and

b. Per cent of worda beyond 10,000

2. Number of words to the phrase and to the sentenee (oounting tive letters to the word)

3. Number of phrases and number of sentences to the paragrapha and $f$ or the total sampling

4. Humber of plurases to the sentence

5. Seore or degree of comprebengt on with which the selections were read and the questions answered

6. The taken to read the selections and angwer the questions on the tests of comprohensi on

Before the books could be judged as sultable by the above oriteria, it was necensary to make an analysis of the degree to whon the aeventeen paragraphs fros each of the live history booke were representative of the booke from whoh they were taken. 
Six teacherg 17 had assisted in the selection of the seronteen paragraphs which they deemed representative of the book. As a check on how well the teachers" gelections were representative of a book as a whole, the author divided the seventeen paragraphs into random halves by placing every other paragraph into one of the two groups. By this procedure the odd paragraphs $(1,3,5,7,9,11,13$, 15, and 17) fell into one group and were marked Odd. The even paragraphs $(2,4,6,8,10,12,14$, and 16) foll into the second group and were marked Even. There were nine paragraphs in the odd half of the sampling and eight paragraphs in the even half. This, however, was of no consequence because the paragraphs were not matohed paragraph for paragraph but were compared through their means and variabilitias. The first paragraph in the odd-numbered half was not nocessarily like the first paragraph in the evennumbered half, nor the second odd paragraph like the second even paragraph, but the odd-numbered paragraphs, considered as whole, and the even-numbered paragraphs, considered as a whole, had means and varlabilities that were signfflcantly alike.

The two halves of each sampling were compared for the six variables given below:

1. Per cent of worda lying beyond 6047

2. Number of sentences to the paragraph

3. Number of phrases to the paragraph

17. Louisville Elementary Sohool Teachers, op. oit., Chapter III, p. 42 . 
4. Average sentence-length to the paragraph, counting five letters to the word

5. Average phrase-length to the paragraph, oounting five letters to the word

6. Score on History Comprehensi on Pest

If the six separate comparison of the two random samplings (odd and even paragraphs) showed that they were alik when compared for ach of the six variables, the two halves of the sampling from each book were certalniy alike. If seventeen widely scattered paragraph from a book about seventeen different topics proved to have means and dispersions that showed no signiflcant differences, then they must be adequately representative of the book as a whole so far as vocabulary and sentence and phrsse-structure are concerned.

\section{Vocabulary Range}

Statistical computationg wero pirst made for comparison of the odd-numbered paragraphs and the evennumbered paragraphs for the number of words lying beyond 6047 on the Thorndike Scale. ${ }^{18}$ (Tables III to VII, page 81 to 85). Computations were made for the mean, standard deviation of the distribution, probable error of the distribution, probable error of the an, and standard error of the standard deviation for each half of the paragraphs.

18. Thorndike, E. L., The Teachers Word Book of Ten Thousand Forde. 1923, p.111. 
The odd-half and the even-inalf wers then compared as to difference between means, probable orror of the difference between means, difference betmeen means divided by the probable error of the difference. If this quotient was 3.00, or greater, the difference was considered significant. (Tables III to VII, pages 81 to 85 ).

The $s$ tandard deviation of the odd distribution was compared with the standard deviation of the even distributions. If the difference botween the standard deviations was as zreat as 3.00 times its probable error, the difference was considerod signifleant. (Tables III to VII, pages 81 to 85 ).

\section{Seatence and Phrase Analysis}

The same procedures were uged for determining the repreaentativeness of the samplings az shown by an analyals of the means and varlables of:

(a) Number of sentences to the paragraph

(b) Number of phrases to the paragraph

(c) Average sentence-length to the paragraph. (ive letters to the word)

(d) Average pirase-length to the paragraph, (five letters to the word)

(Soe Tables VIII to XVII, pages 87 to 97).

3. Degree of Accuragy with Wich the Selections Were Read and the questiong on The Answered 
A comparison was made last for the scores, or number of correct responses to the questions on the teats of comprehensi on.

The study at this point is concerned only with the two halves of the selectlons from one of the books. The author here is cansidering only the correct responses of one group of pupils for each book: those, for instance, from sohool A, taklng the teat on Book I; those from Sehool B, taklng the test on Book II, ete.

All correct responses were tabulated for each paragraph. As ach paragraph had a posslble seore of tour $^{19}$. the sur of all the correct responses to questions on each paragraph was used for the statistioal caloulations. These oalculations vere made for the mans and variablitties of the scores by the same methods used in analyzing the other pive rariables. (Tables LXXX to XCI, pages 203 to 220 ).

o. Comparison of tho Fire History Books

When this method of two comparable halves showed the aelections from each book to have approximately the same means and variabilitios, proeedures were set up to determine any differeness that existed between books.

19. The third paragraph of The Elementary hor Id History. by Beard and Basley has aix questions, and the eighth paragraph of The old Forld Beglnnings of Americe, by Kelty has seven queationa. Percentages were used to equalles these. Thus question in a paragraph of four questions was given a credit of $25 \%$, while one of a possible six answers was given a credit of $16-2 / 3 \%$. Four questions correct on a paragraph containing four possible correot answers was worth 4 ." Four correct responses out of a possible $51 x$ was worth "3-2/3." 
61.

1. Comparison for Vocabulary

The five books were first compared for differenees in rocabulary range for:

1. Per cent of words Ilsted beyond 10,000 on the Thorndike Scale

2. Per cent of words listed beyond 6047

The percentage of words lying beyond 6047 and beyond 10,000 had been determined early in the study. For thi comparison of the books, differences between the percentage were caloulated. Thus, if the rocabulary of Book I showed that 1.7 per cent of 1 ts words lay beyond 10,000 and 3.6 per cent of its words beyond 6047 , while Book II showed 2.1 per oent beyond 10,000 and 3.6 per cent beyond 6047, there was no difference between Book I and Book II on the range of the vocabulary beyond the 6047 boundary and only . 4 per cent between the number of words lying beyond the 10,000. The two books would have the same rank on words beyond 6047, but Book II would 11 higher on the scale for words beyond 10,000. In 11ke manner, each book was compared with each of the other four books. (Table XLIII, page 131).

The flte books ware then ranked as to yocabulary range. Since in the opinion of the writer, the puptls tested know the words lying within the 6047 range with 97 per cent accuracy, the per cant of words below 6047 rather than the per cent above was used to rank the books. 
Thus, if Book I had 3.6 per cent of its nord above 6047 . 96.4 per cent were below. $(100.0-3.6=96.4)$

Book IV with 95.4 per cent of 1 ts vocabulary below 6047 was considered to hare more uncomon words than Book $V$ th a percentage of 95.9 . Ranked on a sale of 5. then, the book with most uncommon words was given a rank of 5, and the book having the least uncommon words, a rank of 1. (Table XLIV, page 134)

2. Comparison for Sentence-leng th

1. Average number of words to the sentenoe (oounting five letters to the rord) for the serenteen selections

2. Average number of sentences to the paragraph $f$ or the seventeen seleotions

Book I was compared with Books II, III, IV, and $V$ for significance of diffarences by uaing the critical ratios for the differenco betwaen theans. (difference botween means divided by the probable error of the difference), and for the standard deviations, (difference between standard deviations divided by the probable error of the alfference). Like methods vere used to compare each book with the other four books. (Table LV, page 152). (Table LVII, page 154). The flve book were ranked according to the maan number of words to the sentence, (Table LIV, page 150) and for the mean number of sentences to the paragraph (Table LVIII, page 155). The book showing the largest mean was ranked 5, and the book showing the 
amallest mean, 1 .

3. Comparison for Phrage-length

To deteralne further difference or I1keness between the books, a conparison was rade for phraga-length:

1. Average number of words to the phrase (counting five letters to the vord) for the seventeen selections

2. Average number of phrases to the paragraph for the seventeen selectiona

3. Avaraze number of phrases to the paragraph for the seventeen selections

The same procedures were used to corpare the books for phrase-langth as was used in making the sentenes-length comparisons. Table LI, LII, LIII pages 146 to 148, and Tables LVII, LIX, LXII, pages 154, 156 and 160), For rank of books see Tables LXI, page 159, LXIII, page 161 and LXV, page 164).

4. Comparison for Derree of Comprehension ith Which the Seleotions Vere Read

As a last analysis for differences, the flve books were compared for the degree of comprehension with wich they were read and the titae taken to read the selections. To do thi 8, the differences between the ans and standard deviations were calculated for each of tire three -quated groups: Curonological Age Group, Mantal Age Group, and Reading Age Group. Each of the twenty-ono pupil. used in sach of the five school-groups making up the 
Chronological as Group had a score for the number of correct responses to the tests on one book; and similarly for each child making ap the Hental Age Group. and the Raading Age Group.

The comparisons and significance of differences for all books are given in TabIes LXXIX, LXXX and LXXXI, pages 198 to 204.

The time taken to read the selections from each book and ansmer the questions wan compared by the same procedures used for the degree of comprehension. The langth of time taken to complete the test, however, is used only in connection wh the degree of comprehension. The pupils were permitted all the time they wi shed up to sixty minutes. T1ma is neaningful in connection with comprehension, but speed is not an indication of degree of comprahensiton as shown by Gates ${ }^{20}$ and Gray. 21 For that reason there is no separate oomparison of books on the time or speed factor for degree of difference.

The same method was used for comparing the books on their degree of accuracy basis for the Mental Age Group and the Reading Age Group. Tables LXXXIV, LXXXV, pages 210 to 211 and Tables LXXXIX, and XC, pages 218 to 219 .

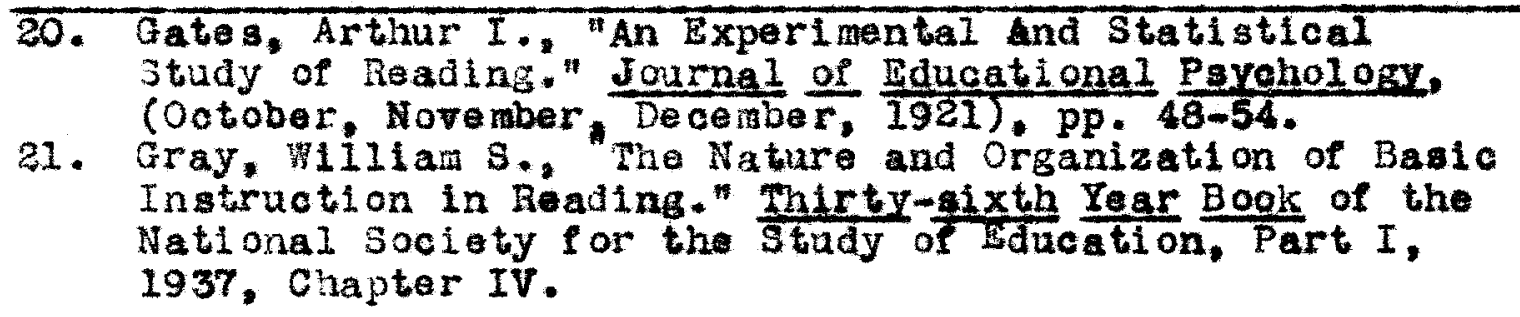


H. Reliabilities of the Teats of Comprehengion

The reliablities of the tests wera calculated by the Spearman-Brown formila from product-moment correlation coefficients between scores on the odd-and even-numbered items:

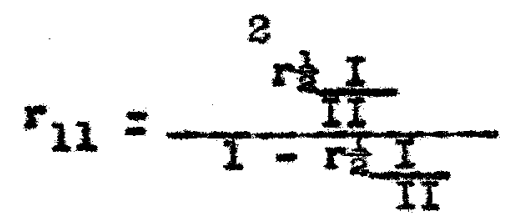

22.

The rellability for each test and the statistical data from whioh the reliability was computed are given in Table II, page 66.

That the so rollability cofficients are high enough to estimate individual scoros with acouracy will be seen from 1 tem No. 12 in Table II. 23

One way therefore assume that these tests are rellable measures of history comprehension so $f$ ar as the ability measured by the tests is concerned.

22. Dunlap, J.T. and Kurtz, A. K., Handbook of Statist cal Nomographe, Tables and Formalas. 1932. Formula No.287, p. 127.

23. Garrett, Henry $\mathrm{E}$.. Statistles in Psychology and Education. 1932 , p. 290. 
TABLE II

MEANS, STANDARD DEVIATIONS AND RELIABILITIES OF THE TESTS

History Comprehension Tests

Book I Book II Book III Book IV Book $V$

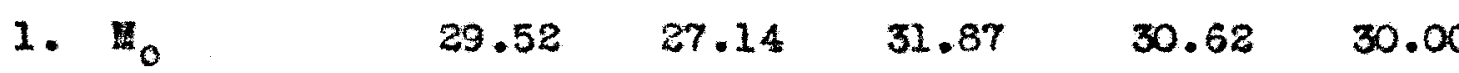

$\begin{array}{llllll}\text { 2. } & 28.17 & 27.76 & 30.43 & 32.21 & 30.85\end{array}$

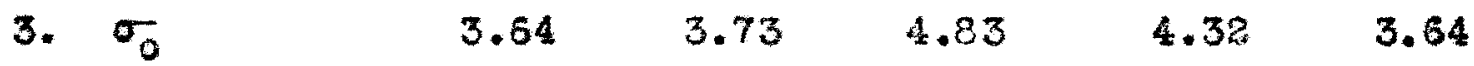

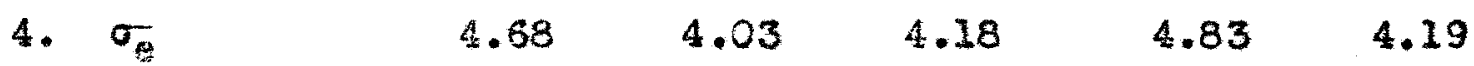

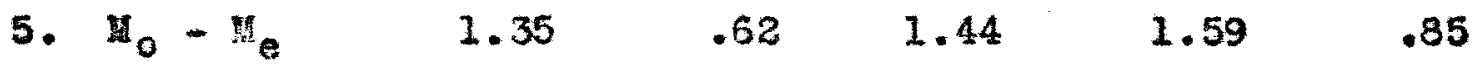

6. P.E.diff. $\quad .656 \quad .698 \quad .672 \quad .772 \quad .639$

7. Diff./P.E. Gift2.056 $\quad .888 \quad 2.142 \quad 2.059 \quad 1.330$

8. $\begin{array}{llllll}\sigma_{0}-\sigma_{0} & 1.04 & .300 & .650 & .511 & .550\end{array}$

9. P. ..diff. $\quad .412 \quad .519 \quad .470 \quad 045 \quad .446$

10. Diff./P.E.diff?.515 $\quad .579 \quad 1.381 \quad .947 \quad 1.232$

$\begin{array}{llllll}\text { 11. } \mathrm{r} \text { 䇰 } & .844 & .846 & .810 & .889 & .846\end{array}$

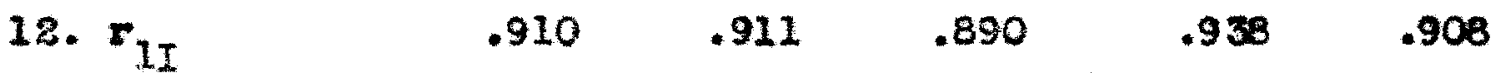

Key to Table II,

1. Means for the odd half of the scorea

2. Means for the even half of the scores

3. Standard deviations for the odd half of the scores

4. Standard devlations for the even half of the scores

5. Differences between the means for the odd and even halves

6. Probable earors of the differences between means

7. Differences between means divided by the probable error of the differences

8. Differences between standard deviations $f$ or the old half of the scores and the even half of the scores

9. Probable errors of the differences between standard deviations

10. Differences between standard deviations divided by the probable error of the differences

11. Corralations between the two halvea of the tests

12. Reliability coefleients of the tests 
I. Buitability of the Books for the Groups That Use Them

The fourth purpose of the experiment, as stated in the problem, was: to determine the suitability of the five history books for the pupils who read them, as judged by an analysls of vocabulary and phrase-and sentence-length, and tests on degree of comprehension as related to age and grade norms.

Studies 242526 disagree as to the per cent of words a ohilo may not understand and still read seloction with a fair degree of accuracy, but they are all agreed that to read with anywhere near comple te comprehengion a child must be able to reoognize practically every word.

In this study the author has placed the number at 97 per cent. Three words out of a hundred does not seem great, but 41 words out of 1354 , as in the case of Book I, may mean that 97 per cent is entirely too 10w. However, If 97 per cent of the words selected by the Thorndike Soale fell below the 6047 boundary, the book was classed as sultable for the sixth-A puplis who use 1 t.

since no tests were made in this study for simplified sentence- or phrase-length, it is assumed that if

24. Burnaide, Margaret, An Experiment to Determne Whether - Teat May Be Devised to Find Out If a Plece of Literature is Placed Correctiy in the Curriculum. rester's Thesis, Indiana Univergity, Bloomington, Indiana, 1933.

25. Stephens, Marion $r$., "Comprehenstion Tests in the Reading Program." American Chlldhood, Volum 20, 1936.pp.46-7.

26. Gates. Arthr I." "An Experimental and Statistiosi study of Reading." Journal of Educational Pgyohology.

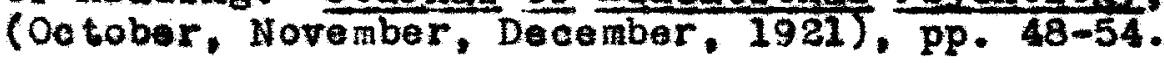


sixth-A pupils read a history book, whose sentence and phrase length is known, th an acceptablo degree or accuracy, that antance-and phrase-length is satisfactory for that book.

Hetropolitan Achlevernent Tests 27 were used to determine the reading ages for all children used in this study, and these were used to determine the sultability of these particular fivo supplementary history books. (It is to be remabered that Sohool $A$ was tested on Book $I$, School $B$ on Book II, ete.).

The subjects fror each school ware grouped in readingaze-grade catagories according to norne of the Hetropolitan Achievement Tests. This ans that all pupils who had a reading age of $9-0(9-0$ to $9-4)$ were placed in the gradenorm group $3.7,3.7$ being the grade-norm for pupils making a reading aze 9 9-0 years. All pupils scoring a reading age of 9-5 (9-5 to 2-9) years were placed in 4.1 etc.

Age-grade groups were made $f$ or ages rangine fron 9-0 years, to 13-10 years in steps of five months, as: $9-0,9-5,9-10,10-0$. Since 75 per cent accuracy was taken as an acceptable detree of comprehension, 28 the number of pupils in each category and the number of correct responses on the tests of conprehenst on were expressed as per cents.

27. Metropolitan Achierenent Testa, op. cit., Chapter III. 28. History Comprehenaion Iests, op. oit., Chapter III, 
It is recognized by the author that the 11 mited numbers of children used in the various age-grade Group are too gmall to warrant extensive generalizations. The author. however. was interested in ascertaining the degree of comprehension fith with these pupils used history books in comon use. Thus, measures vere set up for the varlous aze-grade levels.

Al1 scores on the Hlstary Comprehengl on Tests were tabulated for each chilo in the apecific groups. These scores were then averaged for the specific age and grade group and converted into per cents of accuracy. This means that all the scores were divided by the total posslble soores for that group of ohildren. A per cent of accuraey of 75 per cent meana that children in that perticular age and grade group angwered correctly 75 per cent of all questions on wich thay were tested. Thus "per cent of accuracy" in relation to the book is taken to mean that chlidren who read that specifio book comprehend 75 per cent of what they read. The "per cent of accuracy" might, of course, be 25 per cent, 60 per cent, or any other per cent of the possible correct answers. (Tables LXVIII, page 172, LXIX, page 174, XCII, page 221, LXXI, page 178, and LXXII, page 180 ).

The average number of minutes spent in complating the History Comprehension Tests was avaraged for all agegrade groups. A table was then set up as: 
Chron. Age Reading Age Degree-Accuracy. T1me
$9-5$
4.1
$64 \%$
32

The subjeots used in the experiment had been in the sixth-A grade for three months. Therefore, the normal achlevement for them in terms of Metropolltan Achlevement Test norms Fas:

Age $\quad \frac{\text { Grade }}{22-5}$

Since an accuracy of 75 per cent is here considered an acceptable degree of comprehenst on 29 any book which the subjects in the reading age-group $12-5$ read wh th 75 per cent accuracy was considered suitable for the sixth-A children using it.

The per cent of pupils lying in each Reading Age Group was caloulated and tabulabed with their por cent of acouracy, as:

\begin{tabular}{ccc}
$\begin{array}{c}\text { Reading } \\
\text { Age }\end{array}$ & $\begin{array}{c}\text { Per Cent of } \\
\text { Pupils Tested }\end{array}$ & $\begin{array}{c}\text { Per Cent of } \\
\text { Accuracy on History } \\
\text { Comprehension Teat }\end{array}$ \\
\hline $9-5$ & $4.5 \%$ & $64 \%$ \\
$11-0$ & $11.6 \%$ & $88 \%$
\end{tabular}

It is asumed by the author that a child who show a Reading Age of 10-0 years on the Hetropolitan Achievement Test can also read with as much understanding at all levels below 10w0. This same assumption is made for the author's 旦story Comprehension Tests.

29. Ayer, Adolalde , Some Difficultiag in Elomentary School History. Teachers College Contributiong to Education, No. 212.Teschers College, Columbla Un1versity, New York, 1926, p.32. Burch, Mary C., "Determination of a Content in Literature of Suitable Difficulty for Junior and Senior Students." Genetic Paychology, Monographs,Volume 4, 1928, p.288 
The 11.6 per cent tizen neans that there are 21.6 por cent of this group of pupils in the $12 m$ ronding ago-group. There are t1ve groups $(11-0,11-5,12-10,22-0,12-5)$ between $11-0$ reading leve 1 and the $12-5$ reading 2 evel.

Each of these stepa shows the per oent of puplis scoring that particular reading age. When the per conts for the five Broups aro added, the sull w111 be 55.8 per cont, or sore other ainiler sur.

Interprated, then, 55.8 per cent of the puptls in thi particular group read the selections from one of the history books, ma answered the questions on then with an accureoy of 88 per cent or botter.

The same procedure were uged for Interproting the per cent of understanding for the five books.

Since this study is prisartiy interested in the 12-5 Reading Age Group, the per cent of puplis Iylne in this group and all groups balow was ealculated. If 75 per cent of alI puplis tested read a speciflo book with 75 per oent accuracy, the book was acceptad as suitable for that particular azo and grado group.

The number of minutes usod by ench group was arerazed. No direct sultability was detormined for a book by the length of tiae required to read the selections and answer the questions. The averaige class period, however. for the anxth-A grades is thirty minutes. An assignment. wuch as the above, would nocessarily have to ba covered in approximately thirty inntes to be suitable for these olasses. 
SUMMART OF EXPERIMENTAL AND ANALYTICAL PROCEDURES

The experimental and analytical procedures are disoussed under nine heads:

I. Selection of Materials

II. Vocabulary Analysis

III. Sentence and Phrase Analysis

IV. Analysis of Test Soores

v. Equation of Groups

VI. Analysis of Data to Determine the Degree to Which the Samples Were Representative of the Book from which Thoy Were Taken

VII. Difference Between the Five History Books

VIII. Sultability of the Books for the Group That $U$ se Then

IX. Rellability of Tests

I. Plve supplementary hl story books in common use among the sixth-A Classes of the Loulsville Public Schools were selected for this study. These five history books were read by $1 x$ elementary school teachers for representative samplings. Seventeen paragraphs dealing with seventeen different toplos were chosen which, in the opinion of the six teachers, met the following criteria:

1. Represented a wide range of subjects

2. Wore suffioiently independent of the context preceding and following that questions upon then oould be anewered wi thout further knowledge of the subjeot matter of the book 
3. Appeared to be representative in diffloulty of the book from whioh they were taken

4. Contalned four major ldeas about which objective tests oould be built

Four major ideas were taken from each paragraph, each idea belng tested with a mitiple cholce question. These tests of comprehensi on were given to five different groups of sixth grade pupils, (one test to each group). Then the pupils had finlshed answering the test que ations, the teste were collected and scored, each being marked for the number of minutes spent in finishing it and the number of correct responses.

II. All words from the seventeen selections from each book were tabulated as to frequency of uage aocording to Throndike's Classifloation ${ }^{30}$ for:

1. Milliclassification of words from 1000 to 10,000

2. Number of words beyond 10,000

3. Number of words bey ond 6047, 6047 being taken as the number of words a normal twefve-year-old child should know

III. Sentence- and phrase-analysis was made for each paragraph in the saiplings from the five books for:

1. Number of phrases

2. Number of sentences

3. Number of phrases to the santenee 30. Thorndike, E. L., op. olt., Chapter II, p. Z. 31. Terman, Louis M., op. cit., Chapter II, p. 4. 
4. Ford length of phrases, counting

five letters to the word

5. Word length of sentences, counting

ive latters to the word

Statistical analysis was made for each of the above

for:

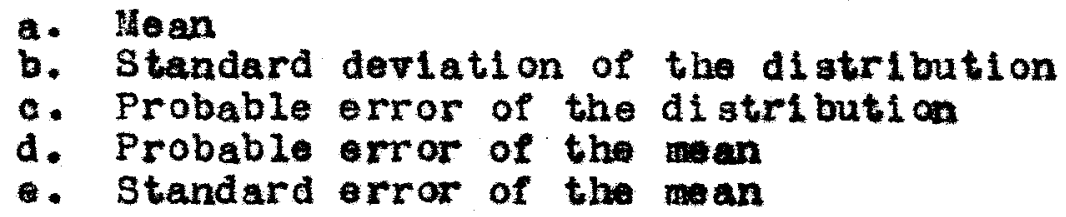

Using the seventeen paragraphs from eaoh book as composite samplings the books were compared on the measures given in II above by oomputing the:

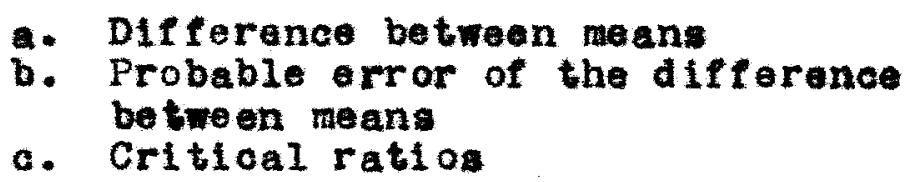

The books were then compared for variabilities of the ge same measures (III above) by computing the:
a. Difference between standard deviations
b. Standard error of the difference
c. Probable error of the difference between standard deviations

If a difference divided by its probable error is 3.00 or more, it is considered significant; if less, it is considered not significant. If a difference is slgnificant it is marked "Yes;" if not significant, "No." 32

The tests of comprehengion were scored by giving a credit mark of one for every correct response. 32. Link, H. C., op. c1t., Chapter III, p. 8 
The scores were used in two ways:

1. Raw scores, which were used in making the statistical comparisons of the alfference between means and standard deviations

2. Por cents of accuracy, (the number of corract responses divided by the possible correct responses). where it was necessary to have a cominon unit for determining the per cent of accuracy with which an age-grade group understood the tests of comprehensiot.

V. Five group of twenty-one pupils sach were paired on three bases:

1. Puplis of the same sex and chronologlcal age

2. Pupils of the same sex and mental age

3. Puplis of the same sex and reading ago

This method of equating three groups of pupila on a one-trait basis was used because of reasons given in chapter III $(p .51 .17)$.

vI. Two mothods were used to determine whether the paragraphs selected were reprasentative of the book from whi oh they were taken:

1. Teacher Judgment

31x teachers selected seventeen paragraphs which in their opinion vere representative of the book from which they were taken

2. Statistical Measures

The odd-numbered paragraphs ware compared with the evennumbered paragraphs for: 


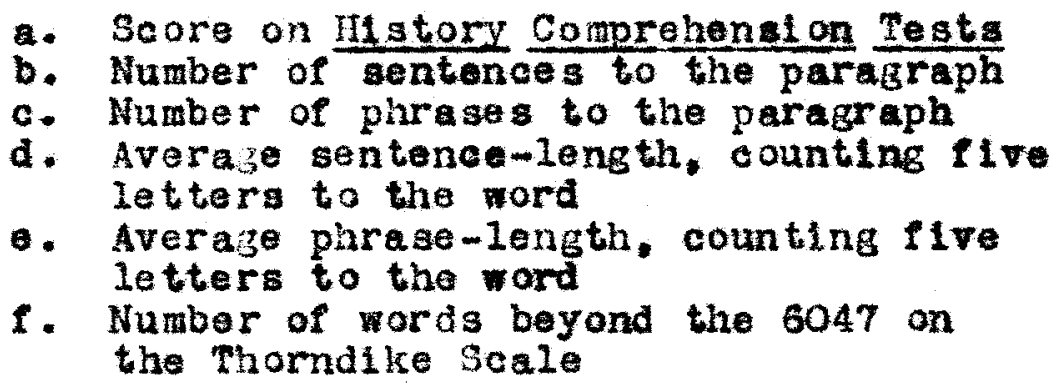

VII. The five supplementary history books were compared on the measureg Iisted in VI, 2 above for each of the ten comparisona: Book I vith Books II, III, IV, and V: Book II w1 th Books I, III, IV, and V. ote.

The books were than ranked wh respect to:

1. Vocabulary range

2. Sentence - and phrase-length (vords)

3. Average number of phrases to the sentence

4. Average number of sentence to the paragraph

5. Average number of phrasea to the paragraph

VIII. Three usures were used to determine the sultablifty of the books for the groups that use them:

1. Yocabulary range, or 97 per cent of the words from the selections lylng below 6047 on the Thorndike Frequency of Usage Soale 33

2. Sentence- and Phrase-length

No tests were made for sentenee- and phrase-length. The selections were analyzed for their sentence- and phraselength to deterwine any relation between long sentenoes Thousend "iords. 1923, p. 111 . 
and phrases, and comprehenst on on samples contalning such.

3. Scores on the Tests of Comprehensi on

75 per cent acuracy was considered sultable comprehension. 34 The pupils used in the study had been in the sixth-A, or upper sixth grade, or three montha. This gave them arade norm of 6.8 . Children showing a reading age of 12 years and 5 months on the Metropolltan Achlevement Testg $^{35}$ had a grade norm of 6.8 . If the group of ohlidren read a book with 75 per cent accuracy, it was considered ant table $f$ or them. Or, aince the study was made to determine the suitability of the books for these specific sixth-A groups, if 75 per cent of these pupils read a book with a comprehension of 75 per cent accuracy it was considered of suitable difficulty for them.

IX. The rellabilities of the tests were calculated by the SperimanBrown formula from product moment correlation coeffictents between scores of the odd-and even-numbered 1 tems. The se reliabilities vere high enough to ostimate individual scores ith accuracy.

\footnotetext{
34. Ayer, Adelaide M., and Burch, Mary C., op. clt., Chapter III, p. 70.

35. Metropoliten Achievement Tests, op. cit., Chapter III, p. 46.
} 
STATISTICAL ANALYSIS ON REPASSETATIVENESS OF SELBCTIONS FRIX FIVE SUPPLEMENTARY HISTORY BOOKS 
CIIAPTER IV

STATI ITICAL ANALYSIS OR BSPREBENTATIVENESS OF

SELECTIONS FROH PIVE SUPVLULNTARY HISTORY BOOKS

The validity of the pinding in this study rests upon the assumption that the samplings used for analysis and tests of comprehengion are truly representative of the books examined. 1

From each of the five history books, six teachers ${ }^{2}$ chose seventeen paragraphs which, in their opinion, were representative of the book from which they were taken. As a check upon the soundness of the teacherg' judgmont as to "representativeness" the odd-numbered paragraphs, $(1,3,5,7,9,11,13,15,17)$, were compared with the ovennumbered paragraphs, $(2,4,3,8,10,12,14,16), N$, or number of cases, belng 9.00 in the odd half and 8.00 in the even half.

This comparison of the two halves was made for:

1. Number of words lying beyond the 3047 rank on the Thorndike $\mathrm{Scale}^{3}$

2. Nuraber of words to the sentence (five letters to the word)

3. Number of words to the phrase (five Ietters to the word)

4. Number of sentences to the paragraph

5. Number of phrases to the paragraph

I. Representativeness of Samplings, op. alt., Chapter III, pp. $57-58$.

2. Selection of Samplings, op. cit., Chapter III, pp.42-43.

3. Thorndike, E. L., The Teachers itord Book of Ten Thousand words. 1923, p. 111. 
6. Degree of accuracy with which the selections were read and the questions answered

Statistical analysis of the even paragraphs and the odd paragraphs are given in the tables that follow, pages 84 to 118 .

In the upper half of the tables, under the captions "Odd" and "Even," are given the:

1. Hean

2. Standard deriation of the distribution

3. Probable error of the distribution

4. Probable error of the maan

5. Standard error of the standard deviation

In the lower half of the table are given the comparison of the Odd and Even halves for:

1. Differences between means

2. Probable error of the difference between means

3. Difference between means divided by their probable error

4. Difference between standard deviations and the probable error of the standard error of the difference between standard deviations

5. Standard error of the difference between standard deviations

1. Comparison for the Number of Words Lylng Beyond 6047

Table III, page 81, shows the comparison of the 
odd-nambered paragraphs wth the even-numbered paragrapha of Book I for the number of word a beyond the 6047 rank.

The odd-numbered paragraphs have a mean of 2.78 words beyond 6047. The even-numberad paragraphs have a mean of 3.00 words.

The difference between $M_{1}$ and $M_{2}{ }^{1 s} \cdot 22$. The probable error of the difference between $v_{1}$ and $\mathrm{L}_{2}$ is .824. The difference between means ditided by thelr probable error 16.267. Thioh $1 \mathrm{~s}$ not a slgnificant difference.

The standard deviations are 2.19 and 2.18 respectively. The difference betweon $\sigma_{1}$ and $\sigma_{2} 1 \mathrm{~s} .01$. The standard error of the diffarence between $\sigma_{1}$ and $\sigma_{2}$ is .757 . The probable error of .757 is .510 . The alfference between the two standard deviations, then, is .01 1.510 , which ia not a signifleant difference.

The two halves of the selections from Book I show no signiflcant differencd when compared for the number of words beyond the 6047 range.

4. Link, H. C., NHow Hany Intervievs Are Necessary for Results of a Certain Accuracy " Journal of Applied Psychology, Volume 21, 1937, p. 5 . 
ONE HALF THE PARAGRAPIS COAPARED WITH THE OTHER HALF AS TO NUIEEER OF WORDS BEYOND 6047

\section{BOOK I}

Europe the Mother of Amertaa - Horne and Bucks

\begin{tabular}{|c|c|c|c|c|}
\hline & Odd & & & Eran \\
\hline \multirow[t]{6}{*}{$\begin{array}{l}\text { Gean } \\
\sigma \\
P \cdot E \cdot \\
P \cdot B \cdot U \\
\sigma \sigma\end{array}$} & $\begin{array}{r}2.78 \\
2.19 \\
1.477 \\
.522 \\
.516\end{array}$ & & $\begin{array}{l}\text { Mean } \\
\sigma \\
\text { p. } \\
\text { p.E. } \\
\sigma_{\sigma}\end{array}$ & $\begin{array}{r}3.00 \\
2.18 \\
1.470 \\
.555 \\
.545\end{array}$ \\
\hline & $\mathrm{H}_{1}-\mathrm{H}_{2}$ & .92 & & \\
\hline & P.E. $\left(\mathrm{u}_{7}-\mathrm{H}_{2}\right)$ & .824 & & \\
\hline & Diff $/ F \cdot \mathbb{B}$ di & .267 & & \\
\hline & $\sigma_{1}-\sigma_{2}$ & $.01 \Rightarrow$ & .510 & \\
\hline & $\sigma\left(\sigma_{1}-\sigma_{2}\right)$ & .757 & & \\
\hline
\end{tabular}

The difference between Mean 1 and Mean 2 1s.22. The probable error of the difference between means is .824. The difference between neans divided by their probable error is .267 , which is not a algnificant difference.

The difference between standard deviations is .01. The probable error of the difference between standard deviations is \pm .510 which 18 not algnifloant. 
TABLE IV

ONE HALF TIE PARAGRAPIS COMPARED MTI TH THE OTIER HALF AS TO NUMBER OF FORDS BEYOND 6047

BOOK II

Our Nation's Heritage - Halleck and Frantz

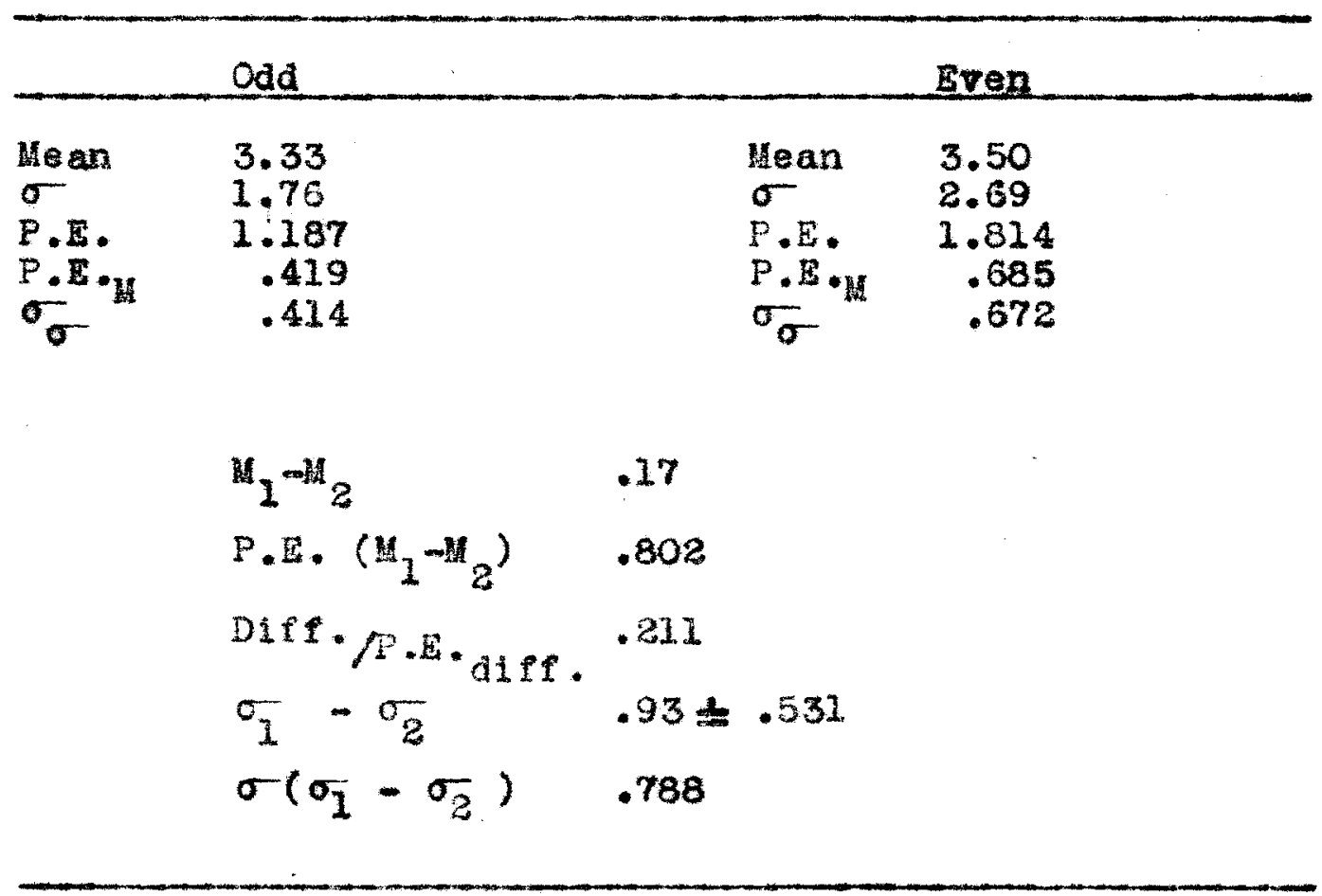

Table IV gives the statistical analysis of Book II when the two halves are compared for the number of words beyond 6047 .

The differenoe between means is .17. This differeno divided by the probable error of the difference between means is. 211 and not a signifioant difference.

The difference between standard deriations 18.93 with a probable error of \pm .531 , which 1 not significant. 
TABLE V

ONE HALF THE PARAGRAPHS COMPARED WITH THE OTHER HAL

AS TO NUMBER OF VORDS BEYOND 6047

BOOK III

The Old Torld Beginnines of Americe - Kelty

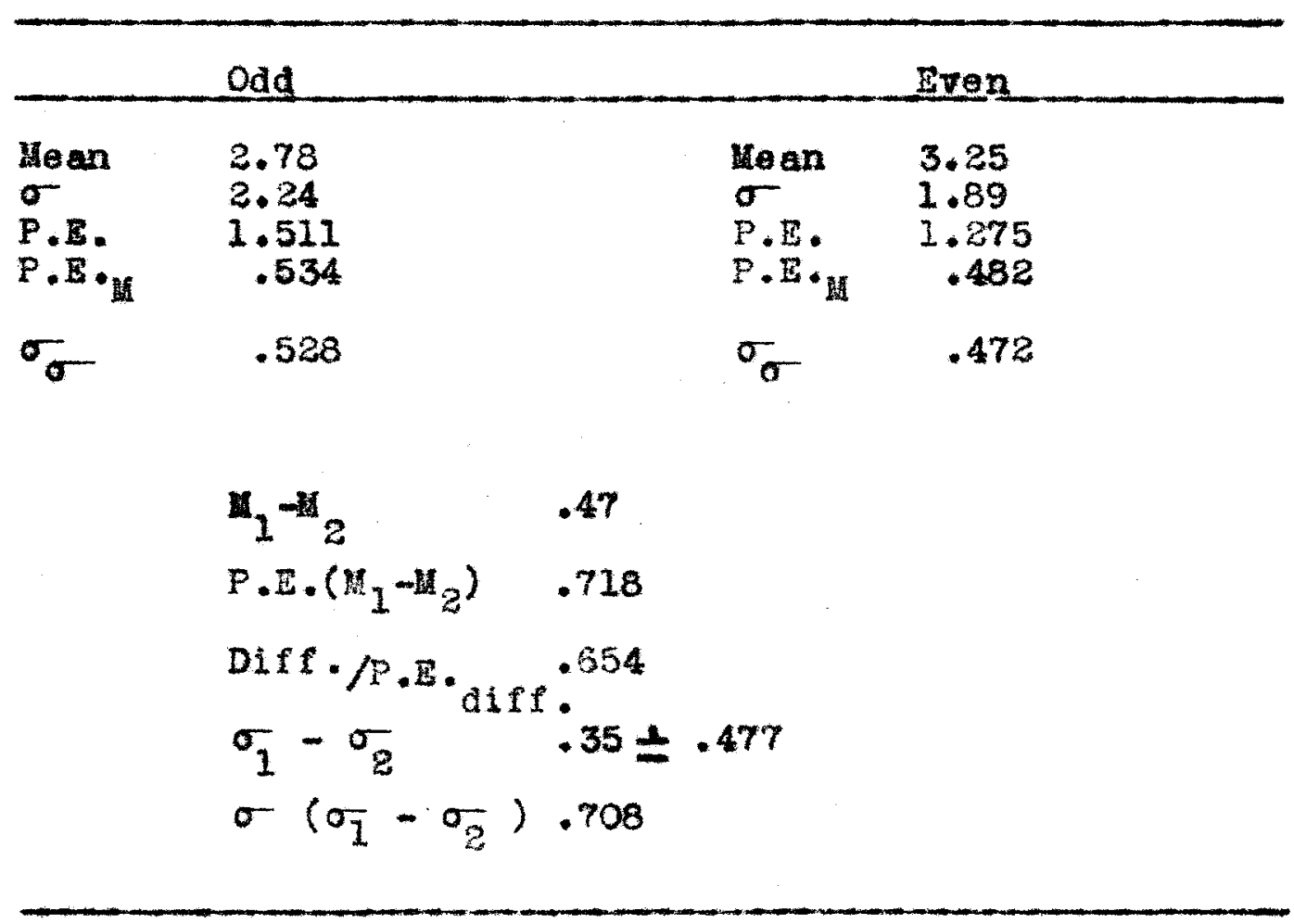

Table $V$ gives the statistical analysis of Book III. The difference between means $1 \mathrm{~s} .47$. The probable error of the difference between means is .718. .47 divided by .718 gives .654 . The difference between means is not signifioant.

The difference between standard devilations is .35 with a probable error of $\$ .477$. The difference between the variabilities is not signifioant. 


\section{TABLE VI}

ONE HALF THE PARAGRAPHS COMPARED FITH THE OTHER IALF AS TO NUUBER OF WORDS BEYOND 6047

\section{BOOK IV}

The American People and Their OId Torld Ancestors-Volilntine

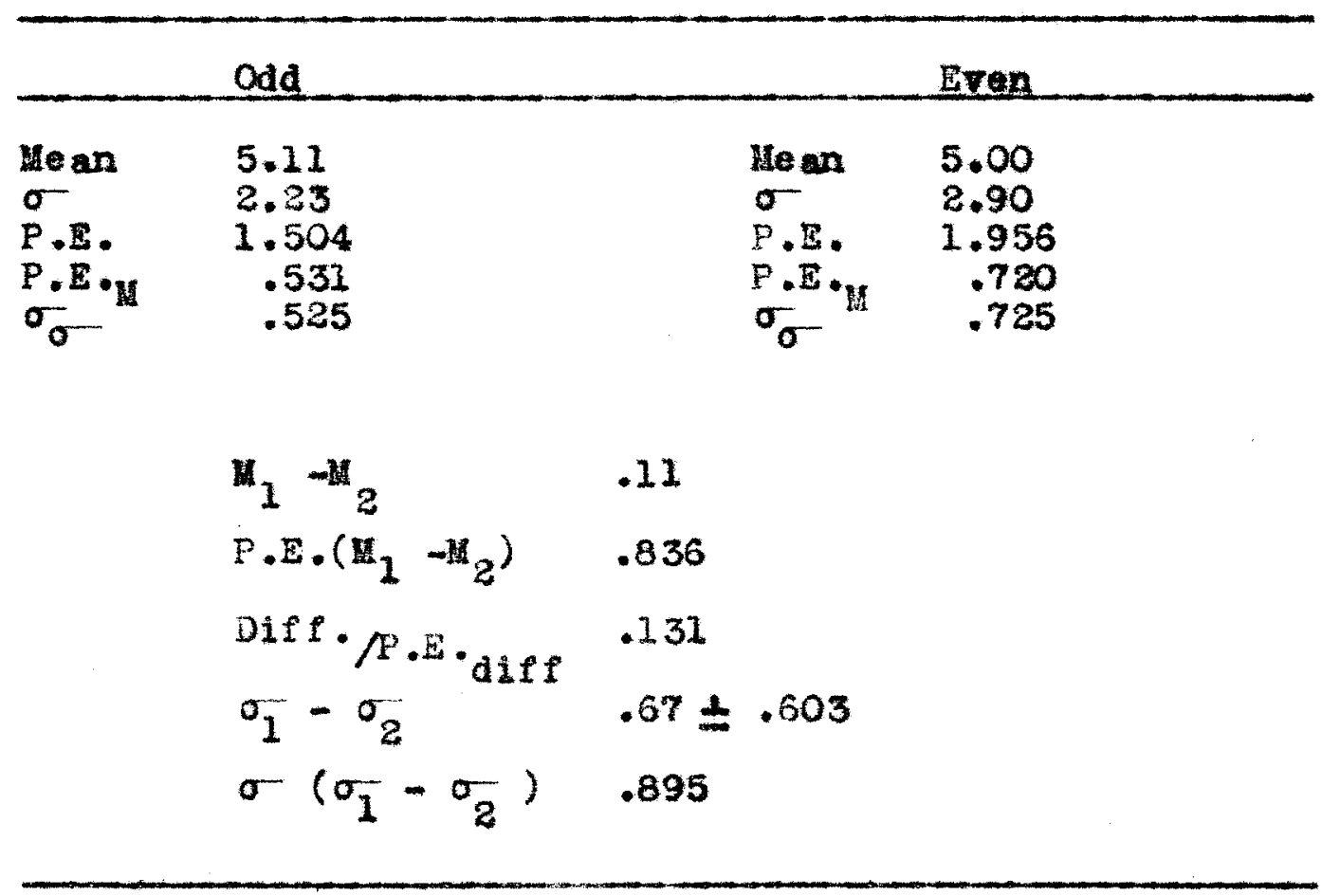

Table VI gives the statistical analyais of Book IV. The difference between means is .11. This difference divided by the probable error of the difference between means is . .131 and not significant.

The difference between standard deviations is .67 with a probable error of $\$ .603$ and $1 \mathrm{~s}$ not significant. 


\section{TABLS VII}

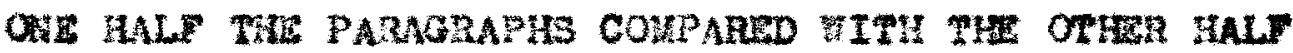
As To vULBen or wonds BEYOWD 6047

BOOK 7

Mlengntarx Tox 1d Matory - Beard and Bagley

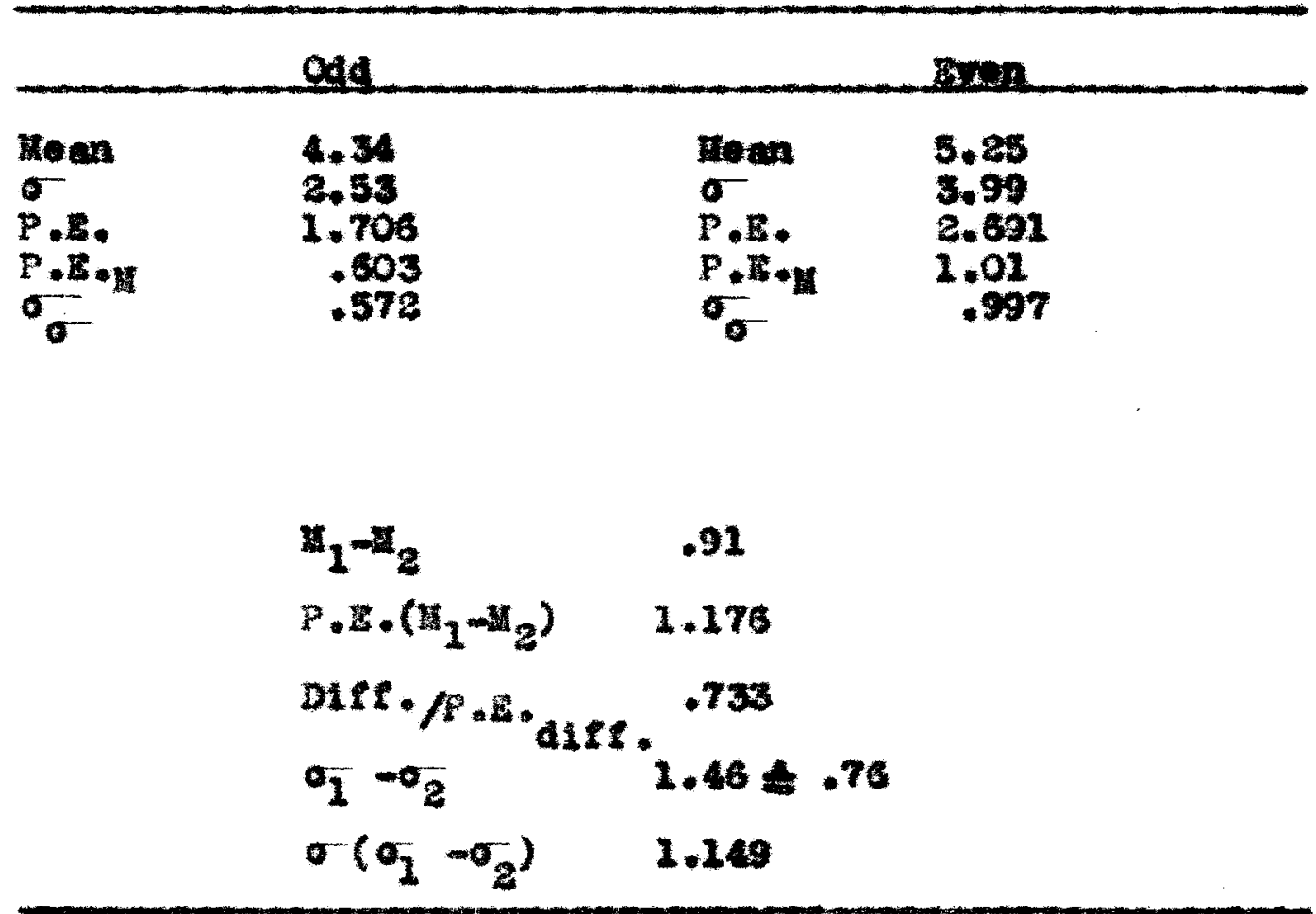

Table VII gives the etatistioal analyate of the two halve of the seleotions from Book $V$. The alfferonce botwen tho moans is .91, but when analyzed, is not algnifleant. The difference between standand derlationa $1 \mathrm{~s} 1.46$ with a probable error of 2.76 . Thl a 19 not a

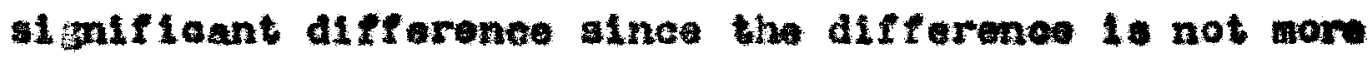
than three times its probable error. 


\section{Comparison $f$ or the number of Words to the sentience}

Comparian of the odd aelections with the oven selections for the number of words to the sentence, (five letters to the word), was used as a second means for determining whether the samplings were representative of the book from which they were chosen.

Statistical analygl was made for each of the books by the same procedures used for the number of mords beyond 6047. These analyses for the number of word to the sentence are given in Tables VIII, XIX, X, XI, and XII, pages 87 to 91 .

The tables give the statistical data for the two halves and ghow the comparison of the two halrea for significant differences between the means and variab111ties.

The disoussion below the bable for each book compares the means and standard deviations and states whether the differences are sienificant.

If a difference divided by its probable error is 3.00 or more, it is considered significant; if less, it is considered not signifleant.

5. Link, H. C., "how Many Interviews Aro Necessary for Results of a Certain Accuracy." Journal of Applied Psychology, Volume 21, 1937, p.5. 
ONR HALF OF THE PIRAGRAPHS COMPARED WITU THE OTHER HALF AS TO WUUBER OF TORDS TO THE SBNTENCE (COUNTINO FIVB LETTERS TO HE WORD)

\section{BOOK I}

Europe the Hother of Americe - Horne and Buoks

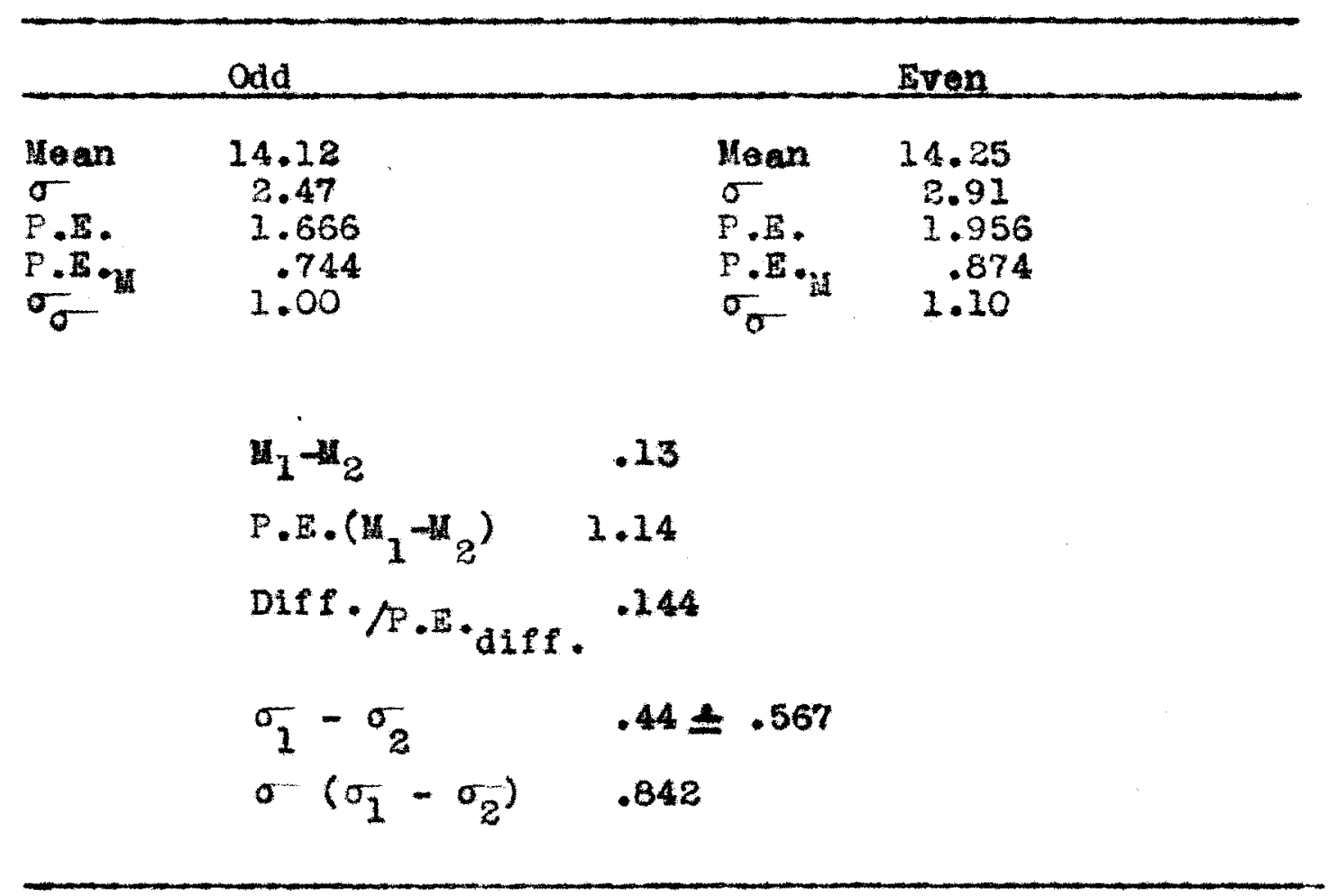

Tho difference between means is .13 . The probable error of the difference between means is 1.14. The difference divided by the probable error of the difference 13.144. Sinoe this quotient is 1egs than 3.00 , it is not significant. The probable error of the standard error of the difference betwsen standard deviations is \pm .567 . This also is not signif lcant since a difforence mat be three times its probable error. 
TABLE IX

OUE HALF OF TIIS PARAGRAPHS COMPARED NITH THE OTHER HALF AS TO NUMBER OF TORDS TO THE SENTENCE (COUNTING FIVE LETTERS TO MEP FORD

BOOK II

gar Nation's Herltage - Halleck and Frantz

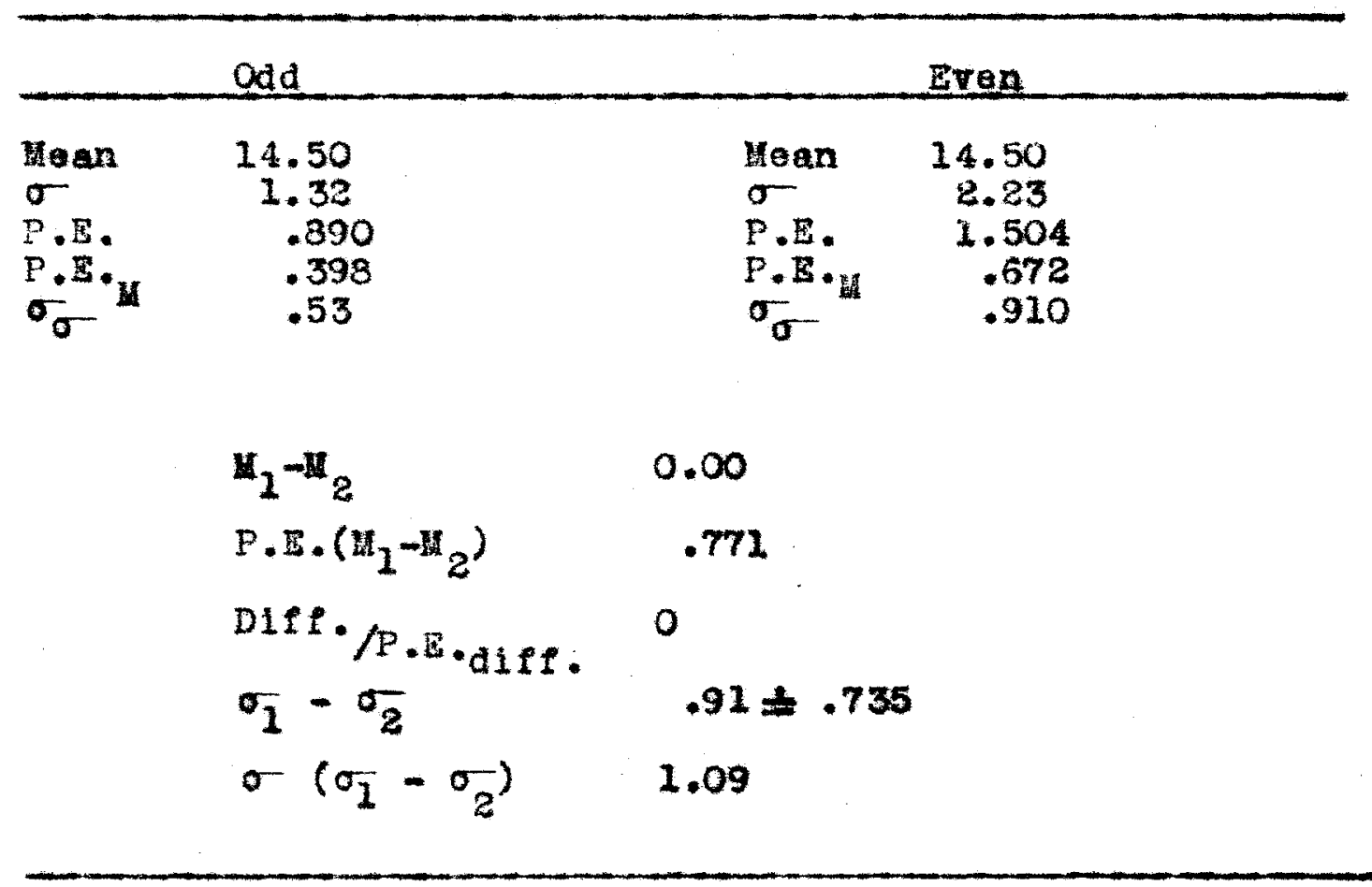

The difference between means is 0.00 . The difference divided by probable error of the difference is mecessarliy 0.00 so there can be no slgniflcant differonoe.

The difference between standard deviations $1 \mathrm{~s} .91$ with a probable error of $\$ .735$. Wich is not signtelcant. 
TABLE X

ONE HALF OF THE PARAGRAPHS COMPARED ITITH THE OTHER HALF AS TO WUIBER OF HORDS TO LHE SENTENCE (COUNTINO FIVE LETTERS TO THE MORD)

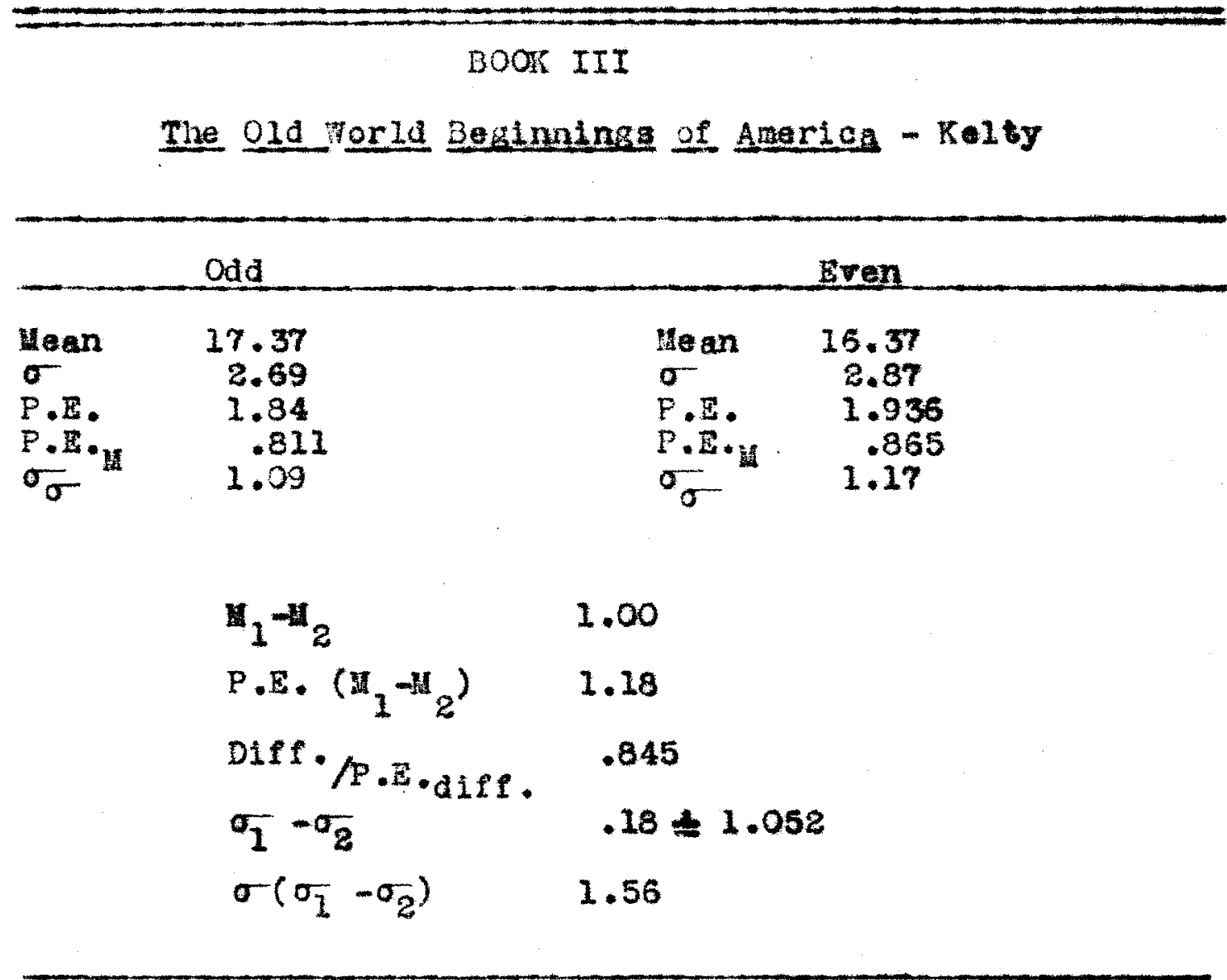

The difference between means is 1.00 . The difference divided by the probable error of the difference between moans is .845 . This is not a significant difforenoe.

The difference between standard deviations is .18. The probable error of the standard error of the difference botween standard deviations is $\$ 1.052$, which 1 s not signiflcant. 
TABLE XI

ONE HALF OR THE FARAGRAPHS COAPARED WITH THE OTHER HALF AS TO NURBER OF FORDS TO TIE SEITLNCE (COUNTING FIVE LETPERS TO TIE GORD)

\section{BOOK IV}

The American People and Their gla Horld Ancestors-Vollintine

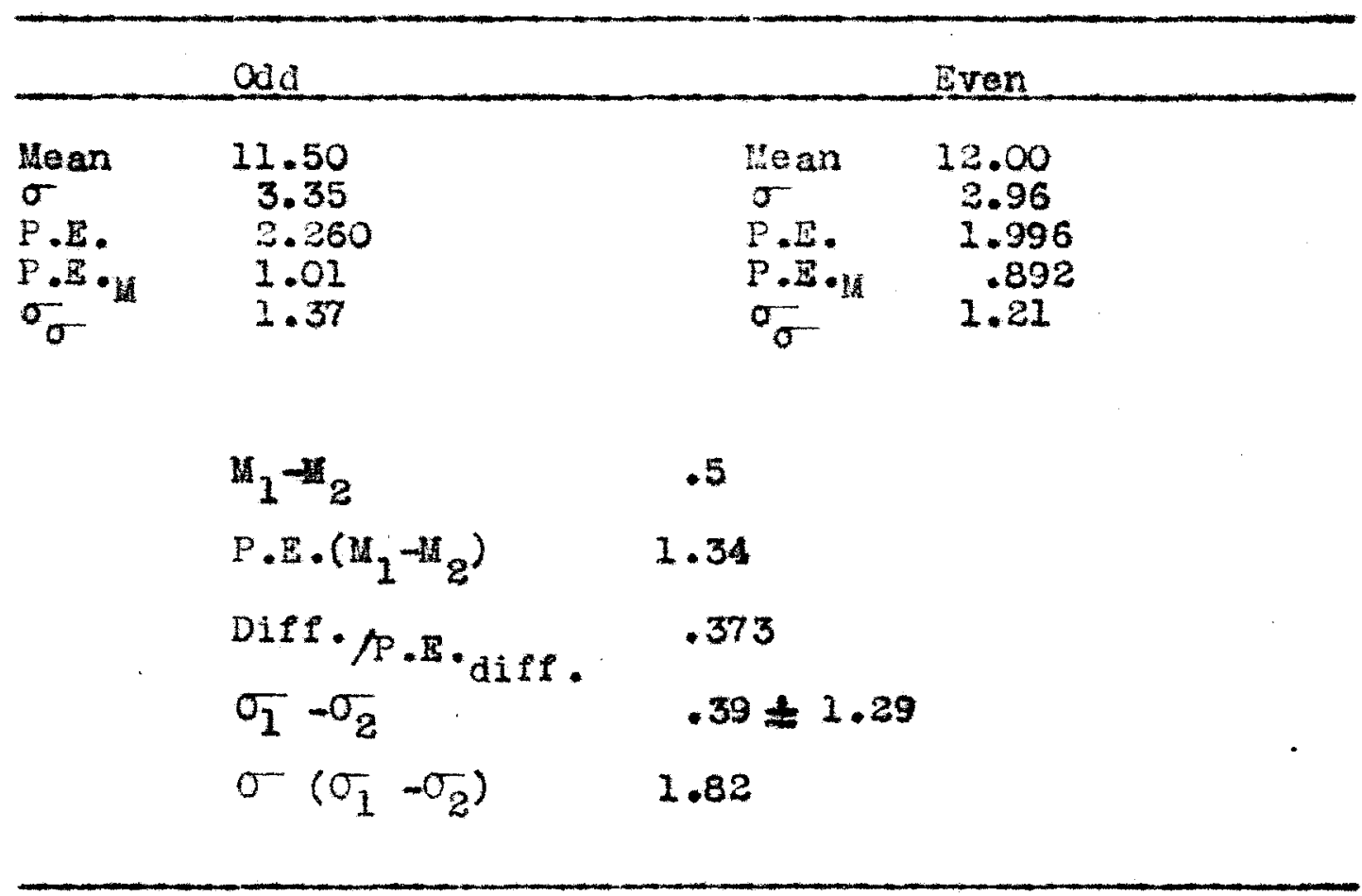

The difference between means is .5. The difference divided by the probable error of the difference between means is . 373, which being less than 3.00 is not significant.

The difference between standard deviations 1 a .39. The probable arror of the standard error of the differenoe between standard deviations is $\neq 2.29$. which is not aignificant. 
TABLE XII

ONE HALF OF THF FARAGRAPIS CORPARED WTTH THE OTHER HALF

AS TO NUMBER OF WORD3 TO THE SENTENCE (COUNTING FIVE

LETTRS TO THF WORD)

\section{BOOK V}

Elementary Horld History - Beard and Bagley

\begin{tabular}{|c|c|c|c|}
\hline & odd & & Even \\
\hline \multirow[t]{6}{*}{ 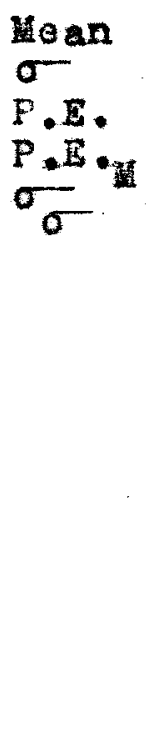 } & $\begin{array}{r}16.62 \\
1.65 \\
1.113 \\
.497 \\
.702\end{array}$ & 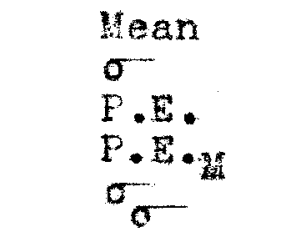 & $\begin{array}{r}16.25 \\
2.29 \\
1.545 \\
.690 \\
.935\end{array}$ \\
\hline & $M_{1}-H_{2}$ & \multicolumn{2}{|l|}{.37} \\
\hline & P.E. $\left(M_{1}-n_{2}\right)$ & \multicolumn{2}{|l|}{.850} \\
\hline & Diff $/ P, E$ & \multicolumn{2}{|l|}{.434} \\
\hline & $\sigma_{1}-\sigma_{2}$ & \multicolumn{2}{|l|}{$.64=.782$} \\
\hline & $\sigma\left(\sigma_{1}-\sigma_{2}\right)$ & \multicolumn{2}{|l|}{1.16} \\
\hline
\end{tabular}

The difference between meang is .37 . The difference divided by the probable error of the difference between means is .434, which shows the difference between means to be not gigniflcant.

The diferonce botween standard deviations is .64. The probable error of the standard error of the difference between standard deviation is 4.782 , which shom the difference between standard deviations to be not significent. 
3. Comparison for the Mumber of worde to the phraes

As a third mean of determining whether the selecti ons were repreaentative of the book from whi oh they were taken, the odd-numbered paragraphs were ompared with the evennumbered paragraphs for differences between thelr meana and variabilities.

The first half of Tables XIII, XIV, XV, XVI, and XVII, pages 93 to 97, gires the statiatioal analyses for the two halres of the selections. The second, or lomer half, gires the omparison of the two halves for any significant difference between the means and standard deviations.

Table XIII for example, shows the mean of the odd-half of the geleotions 1 rom Book I to be 6.37 , and the mean of the even-half of the selections to be 6.50 . The differenoe between the mean $\left(H_{1}\right.$ and $\left.H_{2}\right)$ is .125 . The probable error of the difference between means is .485 . The differenoe between means divided by their probable error is .258. This is not a dignifiant differenoe since it is less then $3.000^{6}$ The standard deviation of the odd-half $1 \mathrm{~s} .91$, and of the aven-half, 1.32. The difference between the two standard deviation is .41. The standard error of the difference between standard deviations is .646 and its probable error is $\$ .435$. This is not gignif leant differenoe since a difference mast be at least three time 1 ts P.E. Results of cartain Accuracy." Joumal of Applied Esychologl. Volume 21, 1937, p.5 
TABLE XIII

ONE HALF THE PARAORAPHS COUPARED WITH THE OTIER HALF AS TO NUHBER OF WORDS TO THE PIRASE (COUNTINO FIVE LETTERS TO TIE WORD)

BOOK I

Europe the Mother of Amertca - Horno and Buoks

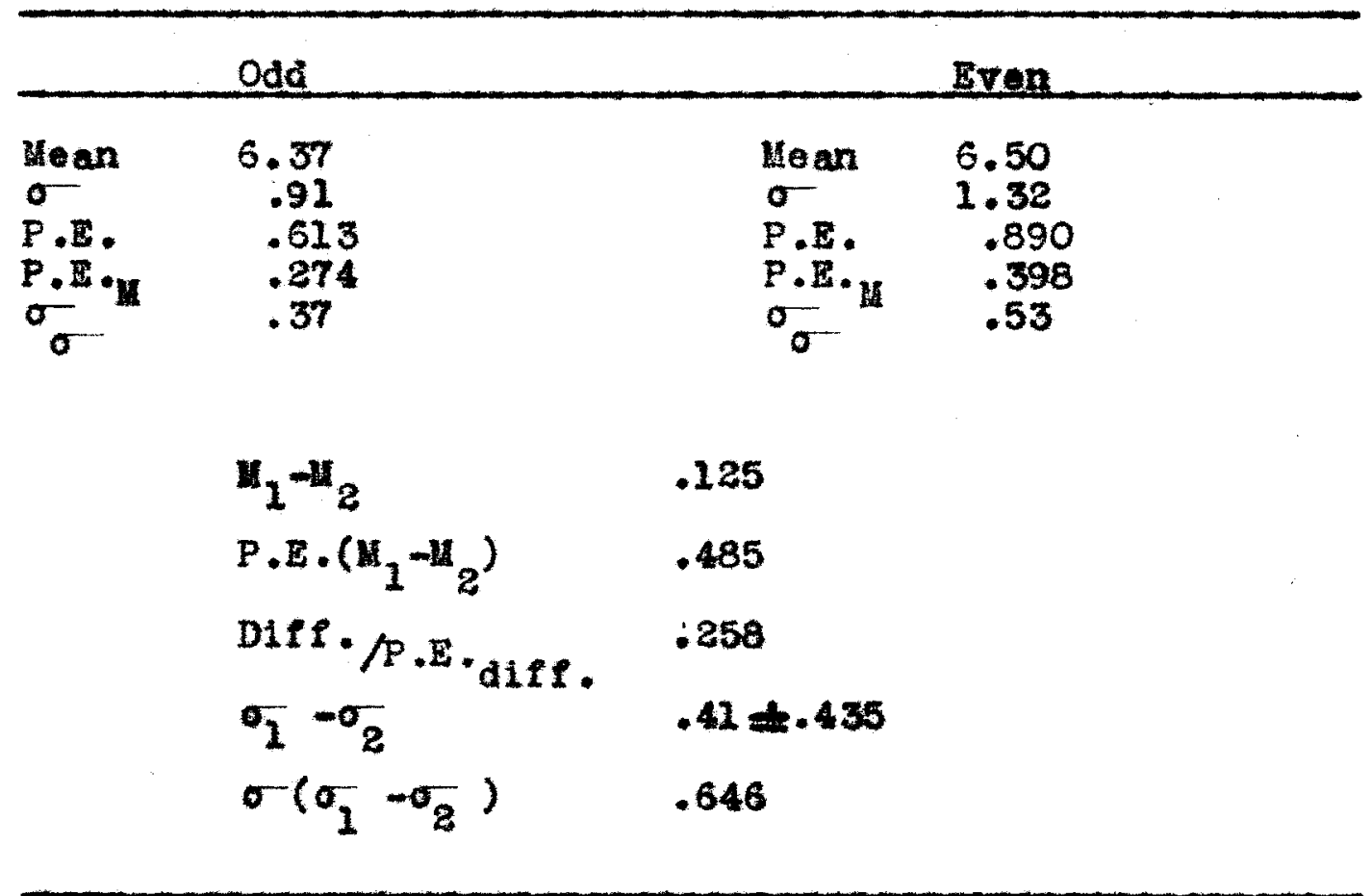

The two halves of the paragraphe from Book I show no significant difference between their means or the ir atandard deviations when oompared $f$ or the number of words to the phrase. (Dlscussion on page 98). 
ONE HALF TW PARAGRAPHS COLPARED TITH THE OTHER HALF AS TO NUUBD OF WORDS TO THE PHRABE (COUNTIM TIV LETTERS TO THE TORD

\section{BOOK II}

Our Nethon's Herltage - Halleck and Frantz

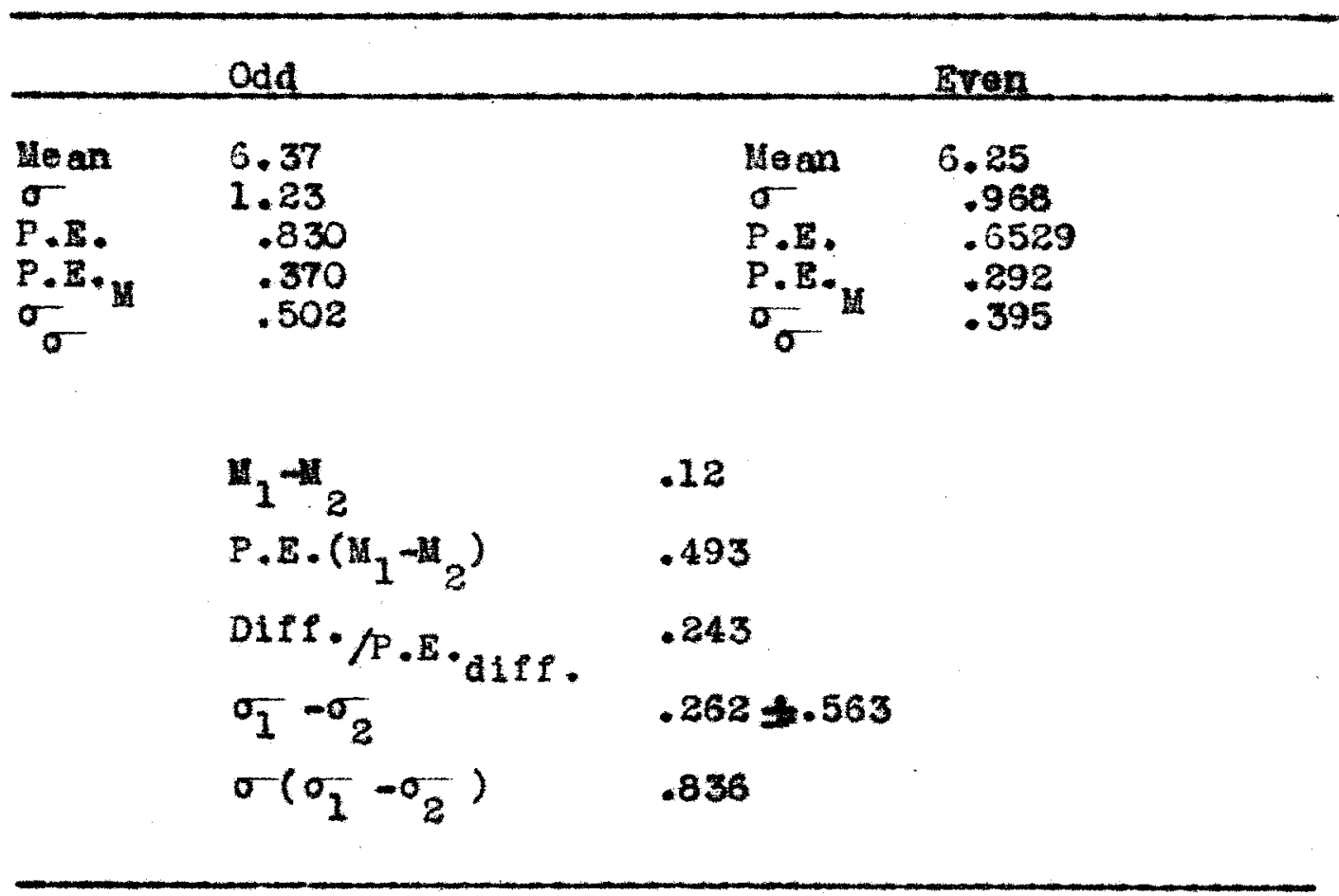

The difference between the neans is.12. The difference divided by the probable error of the differenoe between weans $1 \mathrm{~s} \cdot 243$, which is not algnifleant.

The alfference between the ctandard deviation 1 : -262. The probable error of the standard error of the difference between standard deviations $1 \mathrm{~s} \neq .563$, whoh is not sidnifloant. 
TABLE XV

ONE HALF TU PARAGRAPHS COMPARED NITH THE OFHR HAL

AS TO NUABRR OF FORDS TO THE PIAASE (COUNTIM FTV LETTERS TO THE NORD)

BOOK III

The old Forla Beginninge of America - Kelty

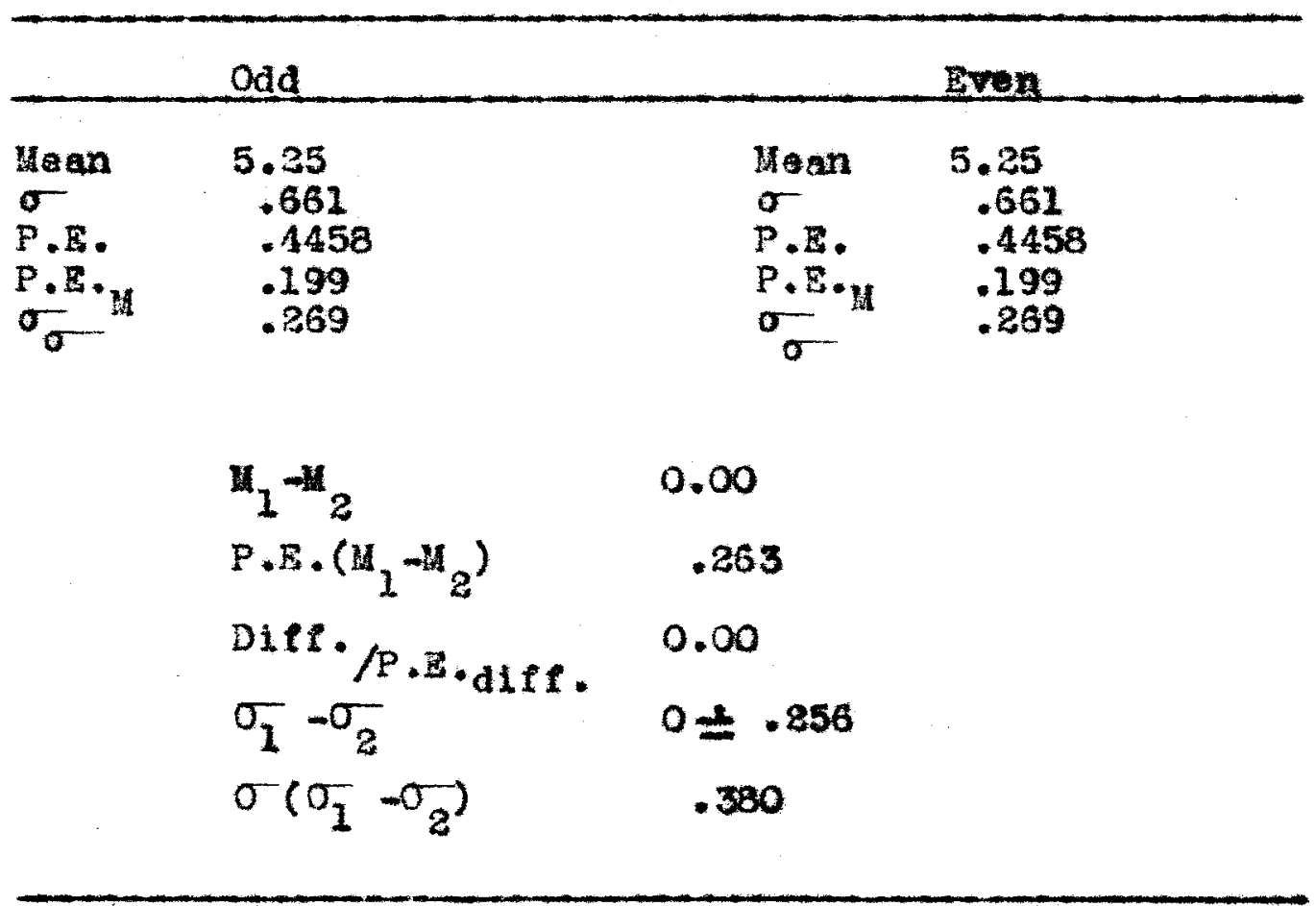

The difference between means is 0.00 . The differance divided by the probable error of the differenoe is therefore 0.00 and not slgnlf 1 oant.

The differenoe between the standard deviationa is 0.00 , which, of course, is not significant. 
TABLE XVI

ONB HALF TIE PARAGRAPHS COMPARED WITH THE OTHER HALF

A3 TO NURBER OF TORDS TO TUE PIRASE (COUNTING FIVE

LETTERS TO THE VIORD)

BOOK IV

The Amerioan People and Their old Torld Ancestorg-Vollintine

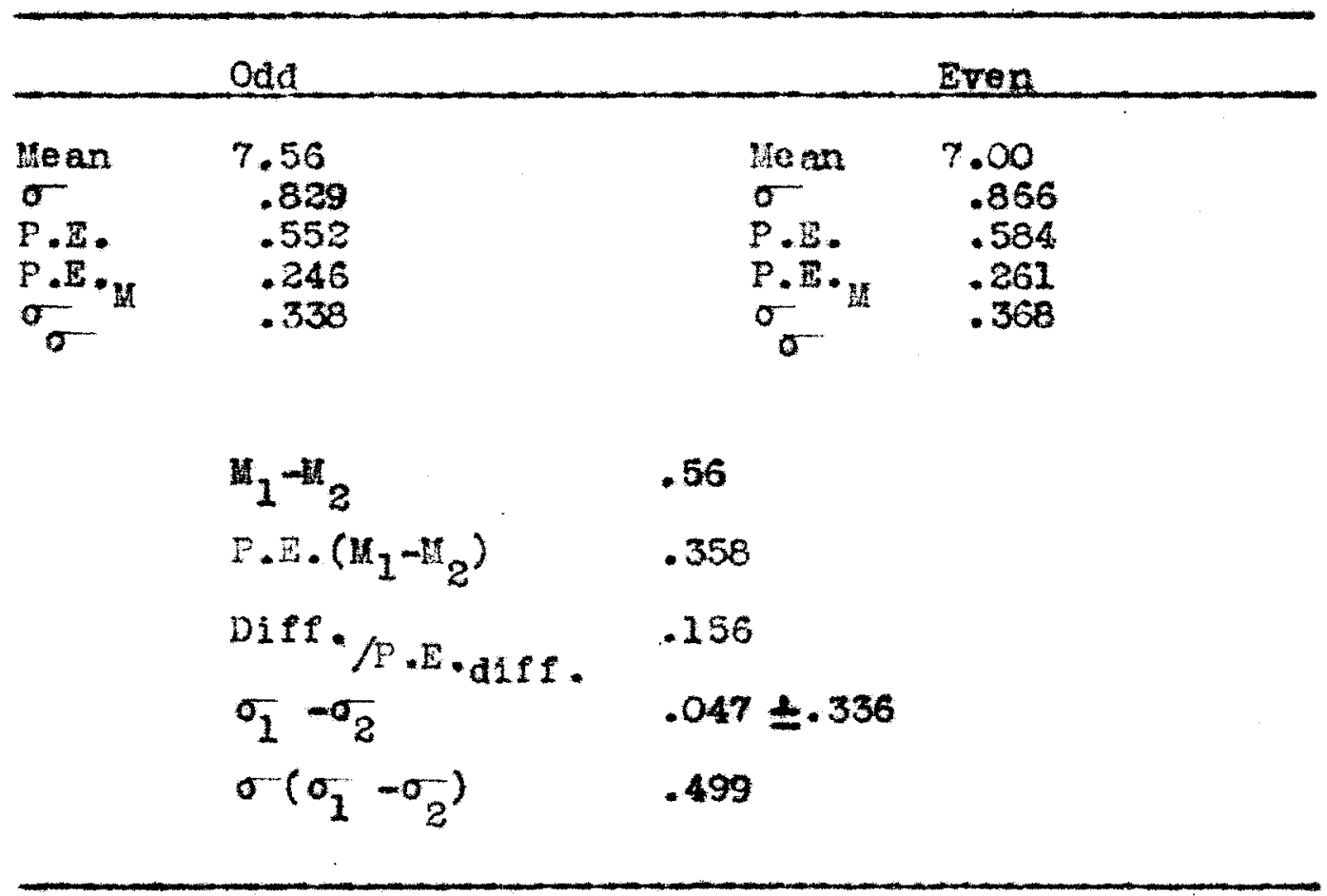

The difference between neans is .56 . The difference aivided by the probable error of the difference is .156, which is not signifleant.

The difference between standard deviations 1.047 . The probabla error of the standard error of the differonos between standard deviations is . 336 . A difference between standard deviations of $.047 \neq .336$ is not a signifleant difference. 
TABLE XVII

ONE HALF THE PARAGRAPIS COMPARED MITH THE OTHE HALF

As TO NUREER OF MORD3 TO THE PHRASE (CONTING FIVE LETTERS TO THE WORD)

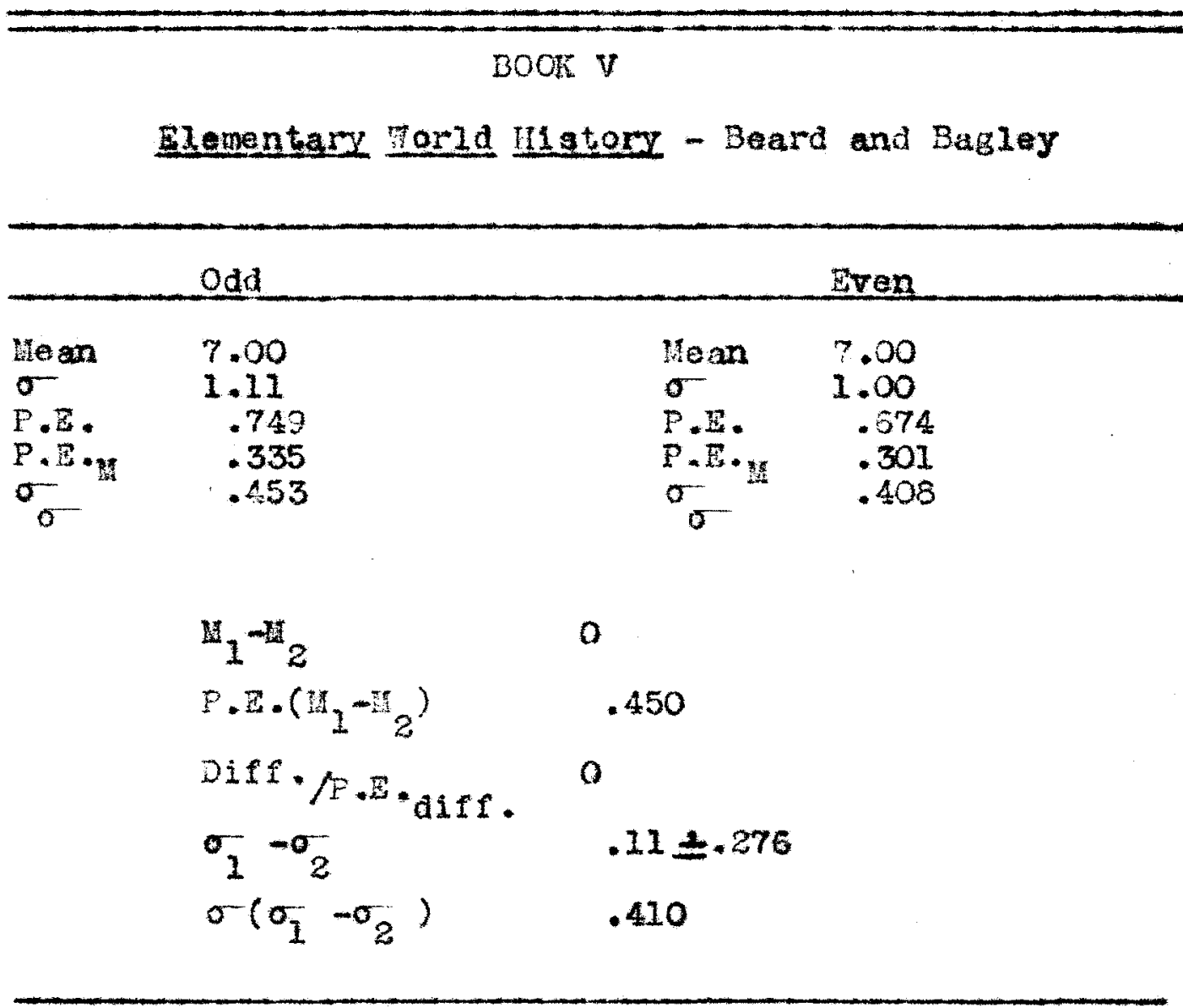

The difference between means is 0.00 . The difference divided by the probable exror of the differance is necessarily 0.00 and not significant.

The difference between the standard deviations is .11. The probable error of the standard error of the difference between standard deviations is .275. A differenes of $.11=.276$ is not signiflcant. 
4. Comparison for tize Number of Sentences to the Paragraph

As a fourth measure of representativeness, the odd and eren selections were compared for the number of sentences to the paragraph.

Tabies XVIII to XXII, pages 99 to 103, give the statistical data for the two halves and show the comparison of the tro halves for algnificant differences between the means and variabilities.

The disoussion below the table for each book compares tine means and standard deviations and states whether the differences are signifleant or not significant.

If a difference divided by 1 ta probable error is 3.00 or more, it is considered stgniflcant, if less, it is considered not significant.

Table XXI ahows the statistical analyai for Book IV. In comparing the two halvas of the book for a difference between means, the table shows no significance. When the standard deviations of the two halves aro compared the difference $1 \mathrm{~s} .081+.393$, which is not a signif loant difference. 
TABLE XVIII

ONE HALF THE PARAGRAPHS COUPARED TITH THE OTHER HALF FOR NUMBER OF SENTENCES

BOOK I

Europe the Hother of Amarica - Horne and Buoks

\begin{tabular}{|c|c|c|c|}
\hline & Cdd & & Eren \\
\hline \multirow[t]{5}{*}{$\begin{array}{l}\text { Hoan } \\
\sigma \\
P \cdot B . \\
P \cdot E \cdot \\
\sigma_{\sigma}\end{array}$} & $\begin{array}{l}5.0 \\
1.69 \\
1.140 \\
.509 \\
.690\end{array}$ & $\begin{array}{l}\text { Hean } \\
\sigma \\
\mathrm{P} . \mathrm{E} . \\
\mathrm{P} \cdot \mathrm{F} \\
\sigma_{\sigma}\end{array}$ & $\begin{array}{l}5.4 \\
1.23 \\
.843 \\
.377 \\
.510\end{array}$ \\
\hline & $x_{1}-u_{2}$ & .4 & \\
\hline & P.E. $\left(M_{1}-M_{2}\right)$ & .633 & \\
\hline & $\begin{array}{l}\text { Diff. P.E.diff. } \\
\sigma_{1}-\sigma_{2}\end{array}$ & $\begin{array}{l}.631 \\
.44 \pm .578\end{array}$ & \\
\hline & $\left.\sigma^{i} \sigma_{1}-\sigma_{2}\right)$ & .858 & \\
\hline
\end{tabular}

The difference between $\mathrm{H}_{1}$ and $\mathrm{H}_{2}$, the means of the odd and even halves, is 0.4 . The probable error of the difference between weans is .633 . The difference between means divided by its probable error is .631 . To be significant this quotient should be at least 3.0

The difference botween $\sigma_{1}$ and $\sigma_{2}$, the standard deviations of the halves is .44 with probable error of \pm .578 . Sinoe this difference is los than three times as large as its probable error (.578) it is not stgnificant. 
TABLE XIX

ONE HAL THE PARAGRAPHS COUPARED WITH THE OTHER HALF FOR NUMBER OF SENTENCES

\section{BOOK II}

Gur Nation's Herltage - Halleck and Frantz

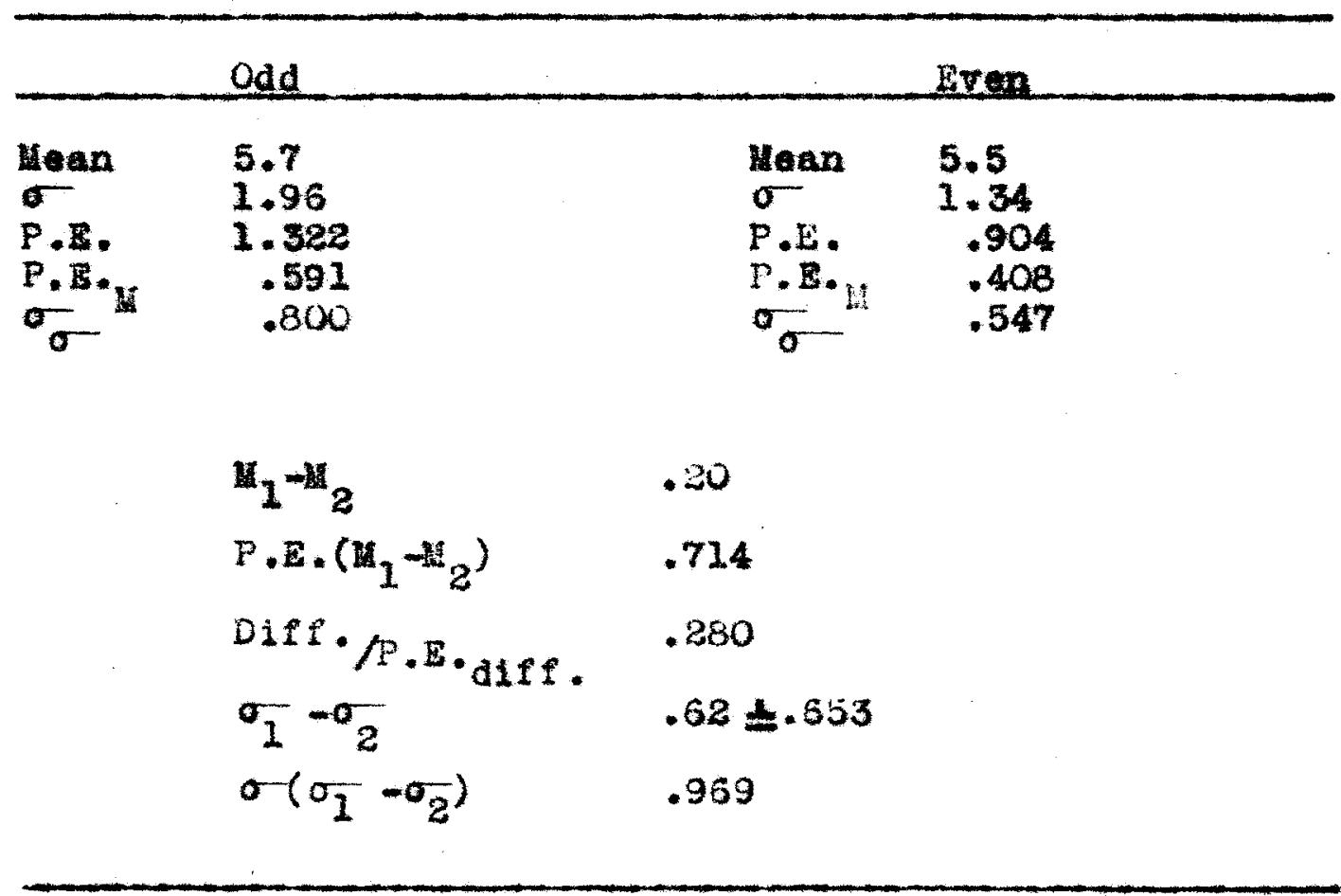

The difference between mans is.20. This atferenes divided by the probable error of the difference between nons is.280, which is not significant.

Tha difference betwaen gtandard deviations 1 . 62. The probable error of the standard error of the differenoe between standard deviations is 1.653 , which $1 \mathrm{~s}$ not aignificant. 
TABLE XX

ONE HALF TIE PARAGRAPHS COMPARED WITH THE OTHER HALF FOR NUMBEF OF SENTSNCES

BOOK III

Tine old idorld Beainnings of America - Kelty

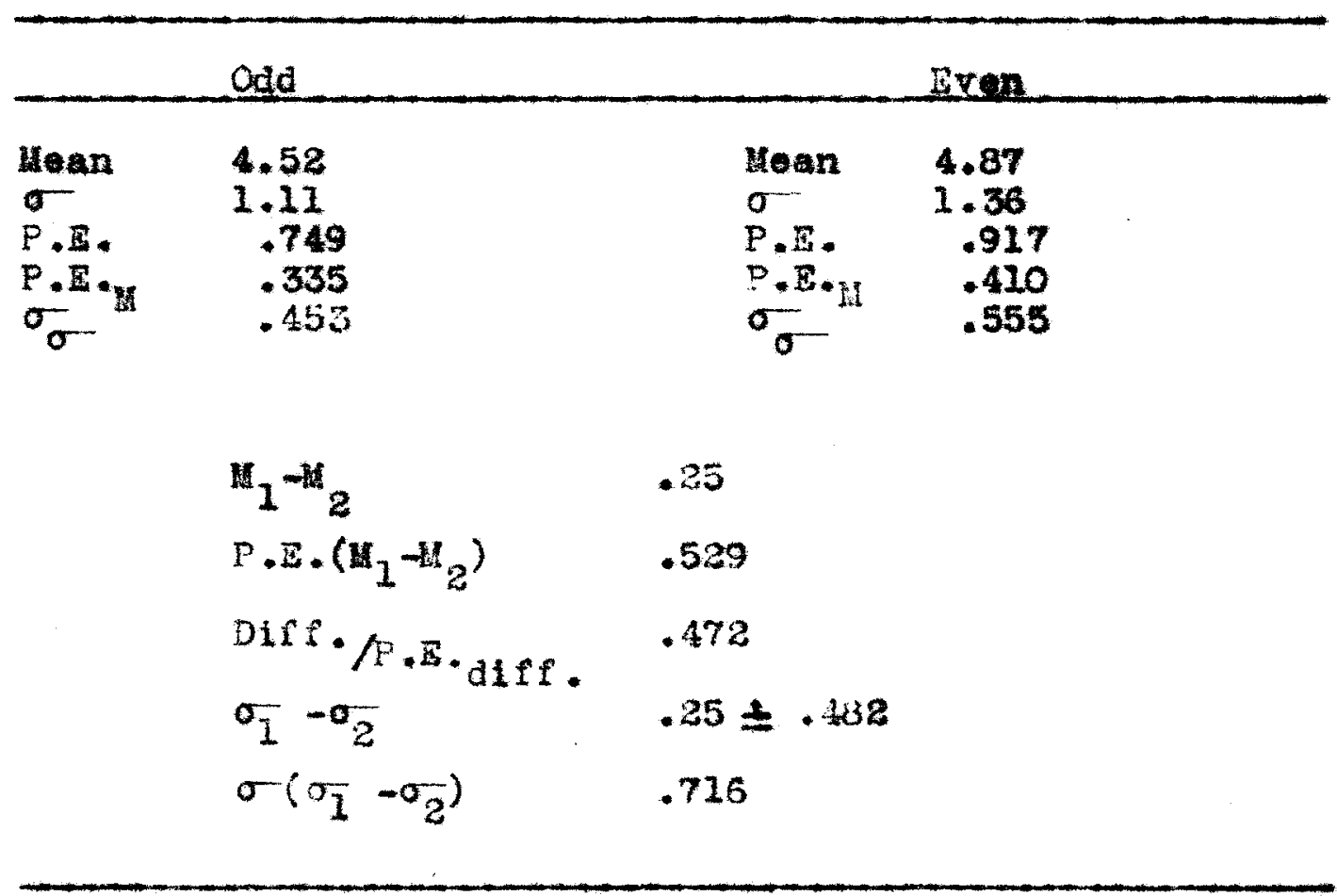

The difference between the means is .25. This difference divided by the probable error of the difference between ans is .472, which is not significant.

The difference between the standard deviations ia .25 with a probable error of \pm .482 , whioh is not aignifloant. 
TABLE XXI

ONE HALF THE PARAGRAPHS COMPARED MITH THE OTHER HALF FOR NUMBER OF STNTENGES

\section{BOOK IV}

The American People and Their old wor ld Ancestorg-Vollintine

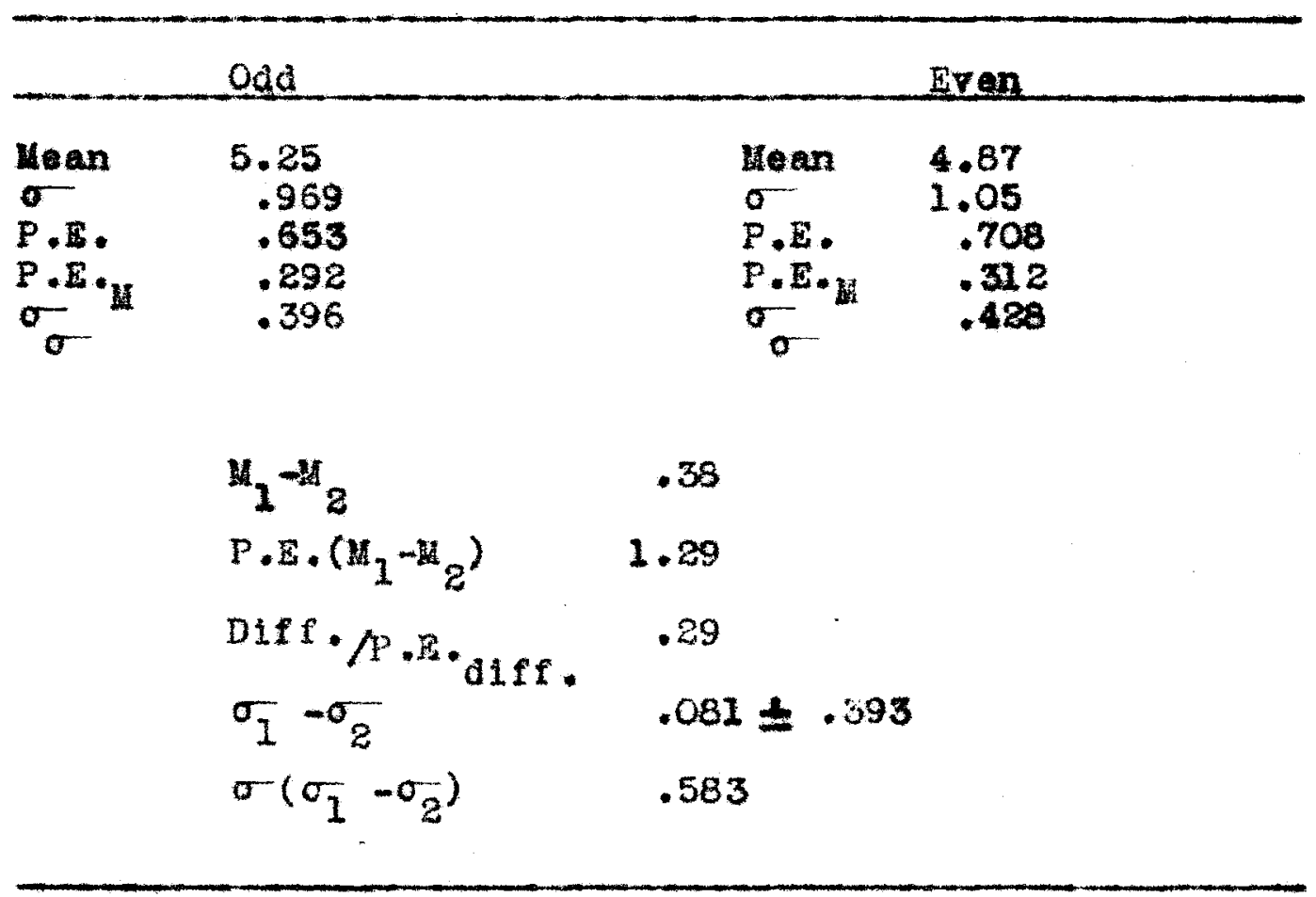

The difference between means is . 38 . This difference divided by the probabie error of the difference between weans is .29, which is not sienificant.

The difference between standard deviations is .081. The probable error of the standard error of the difference

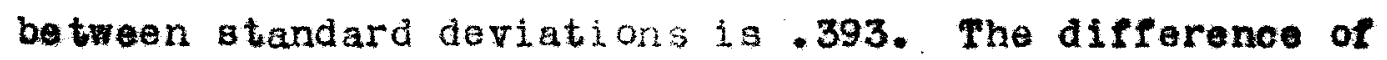
$.081 \pm .393$ is not a significant dufference. 
TABLE XXII

ONE HALF THE PARAGRAPHS COMPARED WITH THE OTHER HALF FOR NUBE? OF SENTENCES

\section{BOOK $V$}

Elementary Lorld Mistory - Beard and Bagley

\begin{tabular}{|c|c|c|c|}
\hline & odd & & Sren \\
\hline \multirow[t]{6}{*}{$\begin{array}{l}\text { Kean } \\
\text { o } \\
P \cdot E . \\
P \cdot B_{\cdot M} \\
\sigma_{\sigma}\end{array}$} & $\begin{array}{l}5.0 \\
2.50 \\
1.012 \\
.452 \\
.612\end{array}$ & 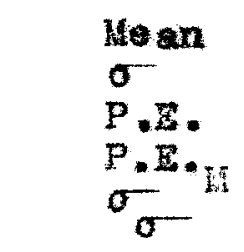 & $\begin{array}{r}5.25 \\
1.28 \\
.863 \\
.385 \\
.530\end{array}$ \\
\hline & $\mathrm{u}_{1}-\mathrm{u}_{2}$ & \multicolumn{2}{|l|}{.25} \\
\hline & $P \cdot R \cdot\left(n_{1}-n_{2}\right)$ & \multicolumn{2}{|l|}{.593} \\
\hline & Diff. $P, \mathbb{E} \cdot$ affe & \multicolumn{2}{|l|}{.421} \\
\hline & $\sigma_{1}-\sigma_{2}$ & \multicolumn{2}{|l|}{$.22 \leq .5 .55$} \\
\hline & $\sigma^{\prime}\left(\sigma_{1}-\sigma_{2}\right)$ & \multicolumn{2}{|l|}{.809} \\
\hline
\end{tabular}

The difference betwoen the meang is .25 . This differenoe divided by 1 to probable error is .421, which is not significant.

The difference botween standard deviations is .22. The probable error of the siandard error of the differenee between standard deviations is .545 , whioh is not similicant. 
5. Comparison for the Marber of Phrages to the Reragreph

As fitth mans of determining the degree to which the seventeen selections we representstive of their reapective books, the two halves of the selections were conpared on number of phrases to the paragraph.

Tablos XXIII, XXIV, XXV, XXVI, and XXVII, pages 206 to 110. give the tatigtloal data for the two halves and show the compariaon of the toro halves for algnifleant difforences betwoen the wans and variabilitios.

The diausat on below the table for each book - ompares the raean and atandard deviations, and states whether the differences are algnifloant or not significant.

Table KAIII for exadplo, show that the raban of odd parasraphs is 11.00 . The mean for the even paragrapha 1s 11.50. The diffarence betweon the means $1 \mathrm{~s} .50$. The probable orror of the diffarenoe between noans $1 \mathrm{~s} 1.44$. The difference divided by 1 ts probable arror 18.34 , which lis not Bignificant.

The atandard deviation of the odd paragraphs is 3.60. Tis standard deviation of the even paragraphs is 3.12. The difference between the atandard deviation 1 . .43 with a probable error of $\leqslant 1.30$, which is not signif laant. 
TABLE XXIII

ONE HAL THE PARAGRAPHS COMPARED WITE THE OTHER HALF FOR NUUBER OF PIRASES

\section{BOOK I}

Europe the Mother of Americs - Horne and Bucks

\begin{tabular}{|c|c|c|c|}
\hline & odd & & Eren \\
\hline \multirow[t]{5}{*}{$\begin{array}{l}\text { Hean } \\
\text { P.E. } \\
P \cdot B \cdot M \\
\sigma\end{array}$} & $\begin{array}{l}11.0 \\
3.60 \\
2.428 \\
1.08 \\
1.46\end{array}$ & $\begin{array}{l}\text { Mean } \\
\sigma \\
\text { P.E. } \\
P \cdot E \cdot \text {. } \\
\sigma_{\sigma}\end{array}$ & $\begin{array}{c}11.50 \\
3.12 \\
2.104 \\
.95 \\
1.27\end{array}$ \\
\hline & $u_{1}-\mu_{2}$ & .50 & \\
\hline & $P \cdot E \cdot\left(M_{1}-M_{2}\right)$ & 1.44 & \\
\hline & $\begin{array}{l}\text { Diff. } / \text {. E.diff. } \\
\sigma_{1}-\sigma\end{array}$ & 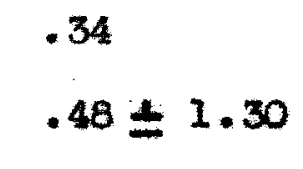 & \\
\hline & $\sigma\left(\sigma_{1}-\sigma_{2}\right)$ & 1.92 & \\
\hline
\end{tabular}

The difference between the means is .50 . This difference divided by ita probable error is .34 and not si gnif loant.

The difference between the standard deviations is .48 with a probable error $o t \pm 1.30$ and is not significant. 
TABLE XXIV

ONE HALF OF THZ PARAGRAPHS COIPARED VITH THE OTHER HALF FOR NUUBB OF PHRASES

BOOK II

Our Nation's Herltege - Halleck and Fantz

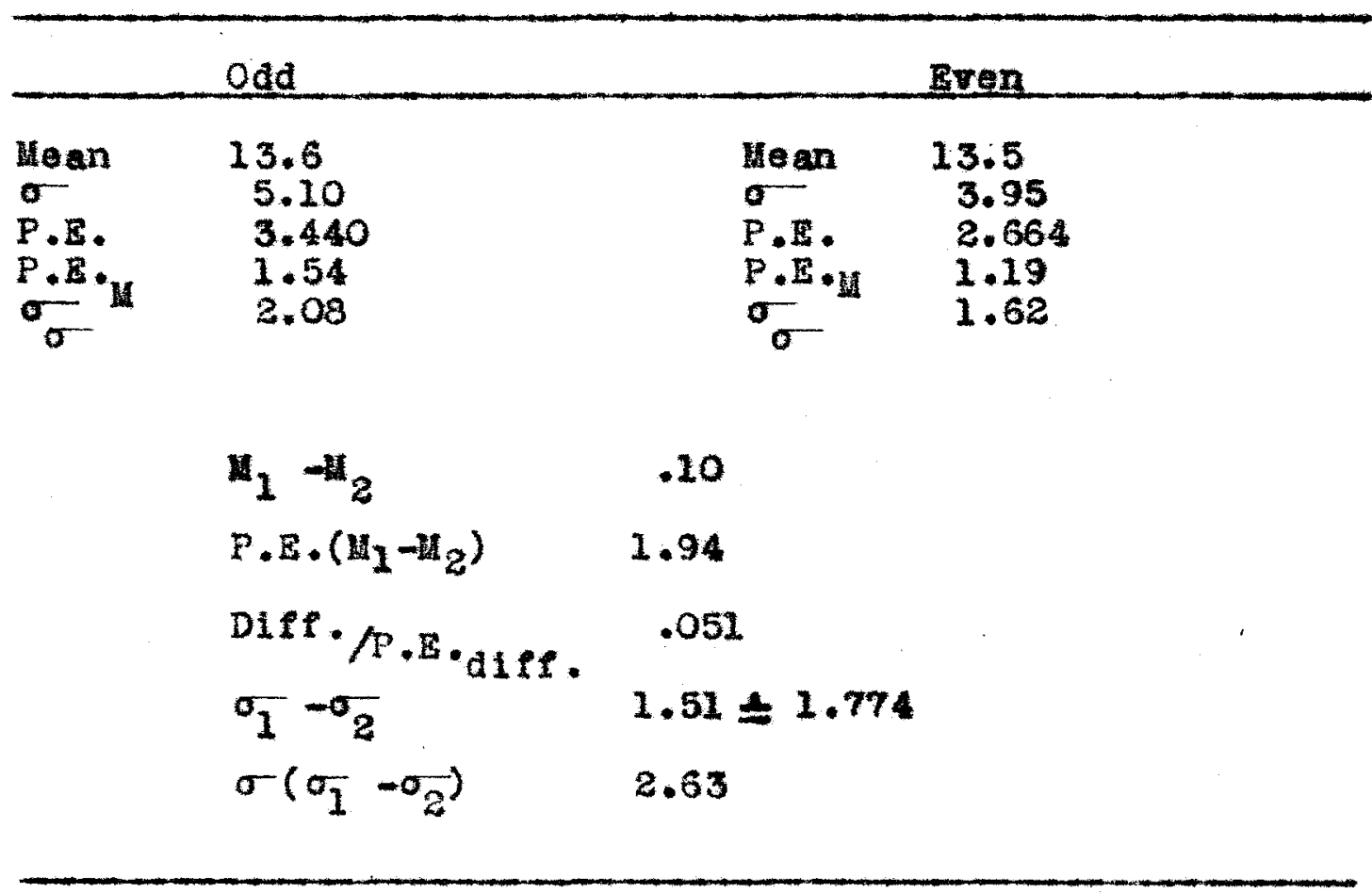

The difference between means $1 \mathrm{~s} .10$. This difference divided by its probable error $1 \mathrm{~s} .051$ and is not significant.

The difference between standard deviations is 1.51 Ith a probable error of \pm 1.774 and is not signiflcant. 
TABLE XXV

ONS HALF OF THE PARAGRAPIS COMARED WITH THE OTHER ITALF FOR NUEBBR OF PHRASES

BOOK III

The old vorld Beglnnings of America - Kelty

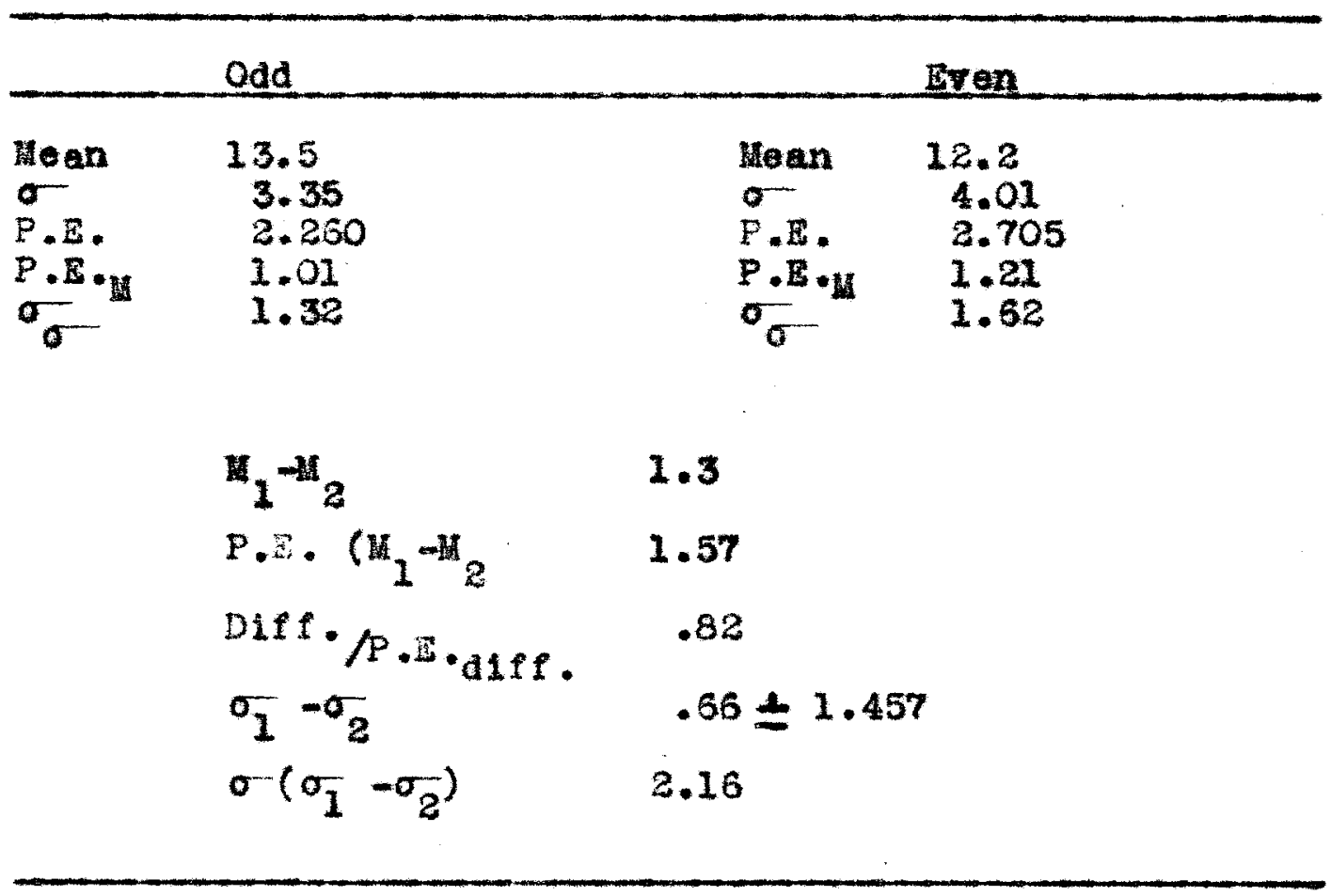

The difference between means $1 \mathrm{~g}$ 1.3. This difference divided by its probable error 18.82 and is not signletcant.

The difference between standard deviations is .66 with a probable error of \pm 1.457 and is not significant. 
TABLE XXYI

ONE HALF OF THE PARAGRAPHS COMPARED UITU THE OTHER HALF FOR NUIRBER OF PHRASES

\section{BOOK IV}

The Amerioan People and Their old For ld Ancestors-Vollintine

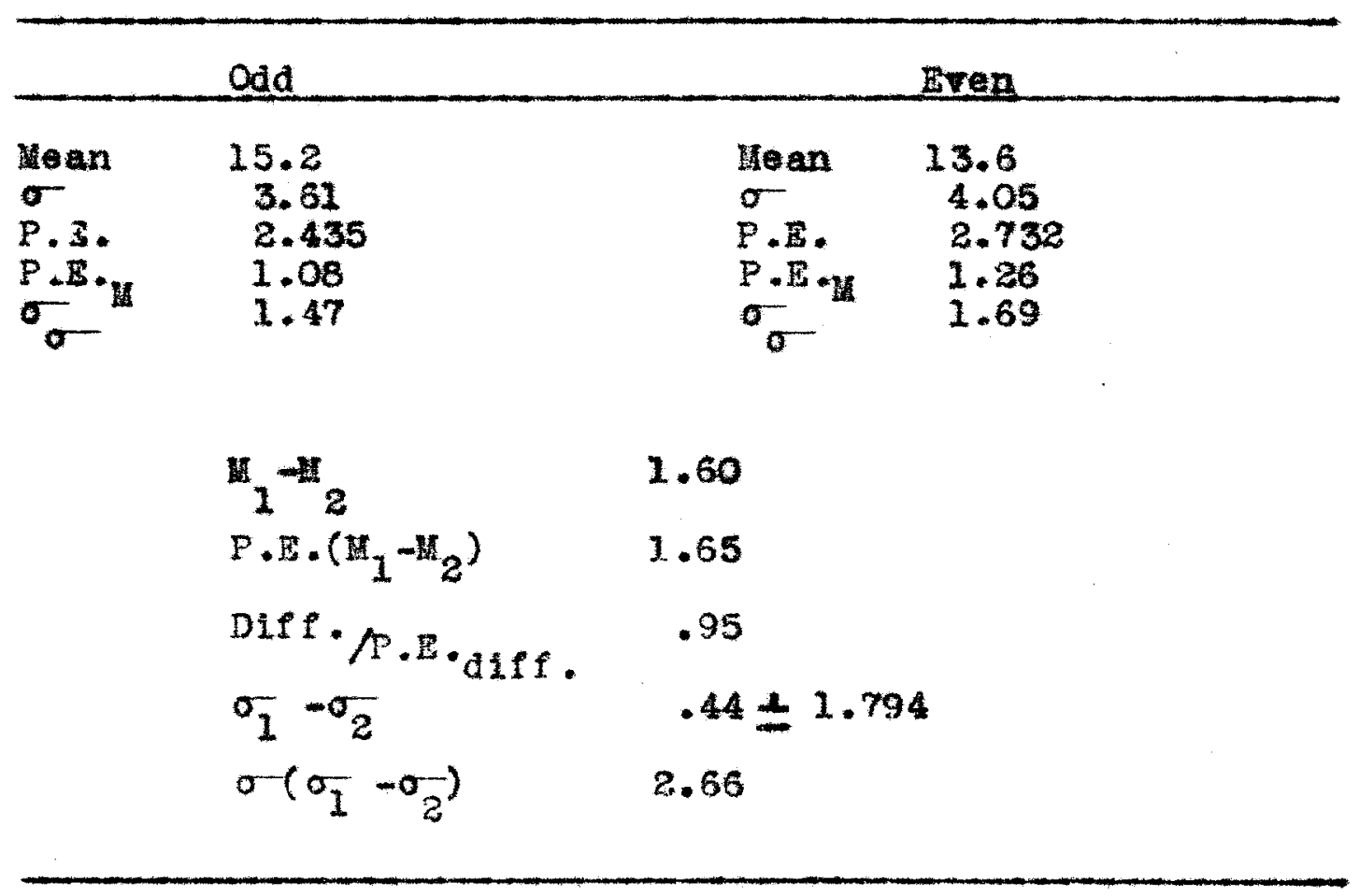

The difference between means is 1.60 . Thls difference divided by tis probable error is .95 and is not signiflcant.

The difference between standard deviations is .44 with a probable error of $=1.794$ and is not significant. 
TABLE XXVII

ONE HALF OF TIE PARAGRAFYS COMPARED UITH THE OTHER UALF FOR NUMBER OF PLRASES

\section{BOOK $V$}

Elementary lor ld History - Beard and Bagley

\begin{tabular}{|c|c|c|c|}
\hline & $\mathrm{Odd}$ & & Exen \\
\hline \multirow[t]{5}{*}{$\begin{array}{l}\text { Mean } \\
\sigma \\
\mathrm{P} \cdot \mathrm{Z} . \\
\mathrm{P} \cdot \overrightarrow{\mathrm{B}} \cdot \mathrm{Bg} \\
\sigma_{\sigma}\end{array}$} & $\begin{array}{c}12.1 \\
4.14 \\
2.792 \\
1.20 \\
1.69\end{array}$ & $\begin{array}{l}\text { Hean } \\
\sigma \\
\mathrm{P} \cdot \mathrm{E} . \\
\mathrm{P}_{*} \cdot \mathbf{B} \cdot \mathrm{H} \\
\sigma_{\sigma}\end{array}$ & $\begin{array}{c}12.6 \\
2.66 \\
1.794 \\
.76 \\
1.08\end{array}$ \\
\hline & $\mathrm{m}_{1}-\mathrm{w}_{2}$ & .50 & \\
\hline & $P \cdot \Sigma \cdot\left(H_{1}-\frac{z_{2}}{2}\right)$ & 1.42 & \\
\hline & $\begin{array}{l}D i f \cdot / P \cdot E \cdot \text { diff. } \\
\sigma_{1}-\sigma_{2}\end{array}$ & $\begin{array}{c}.35 \\
1.48 \pm 1.349\end{array}$ & \\
\hline & $\sigma\left(\sigma_{1}-\sigma_{2}\right)$ & 2.00 & \\
\hline
\end{tabular}

The difference between means is .50 . This difference divided by its probable error is .35 and is not aignifloant.

The difference between standard deviations is 1.48 with probable error of \pm 1.349 and is not gignifleant. 
6. Comparison for the Degree of Comprebengi on Ith Which the Selections Were Read and the Questions Answered.

As a sixth and last weans for determining the degree to wich the selections were representative of the book from which they were taken, the odd-numbered paragraphs were compared with the even-numbered paragraphs for the degree of comprehension with which the pupils read the selections and answered the test questions on them.

A point of 1.00 was given for sach oorrect response on the teat question of comprehenaion. (Appendix B) The number of correct reaponses was counted for each paragraph. The sums of the correct responses for the odd paragraphs wes compared with the sums of the correct responses for the even paragraphs.

The statistical data for the correct reaponses for the two balves of the geloctions 13 giten in Tables $X X V I I I, X X I X, X X X, X X X I$, and XXXII, pages 111 to 115, which show the comparison of the two halves for glgnificant differenoes between the means and variabilities.

The discusai on below the table for ach book comparea the means and standard deviations, and states whether the differences are significant or not. 
TABLE XXVIII

ONE UALF OF TAE PARAGRAPHS COMPARED WITH THE OTHER TALF FOR SCORES

BOOK $I$

gurope the Mother of America - Horno and Buck

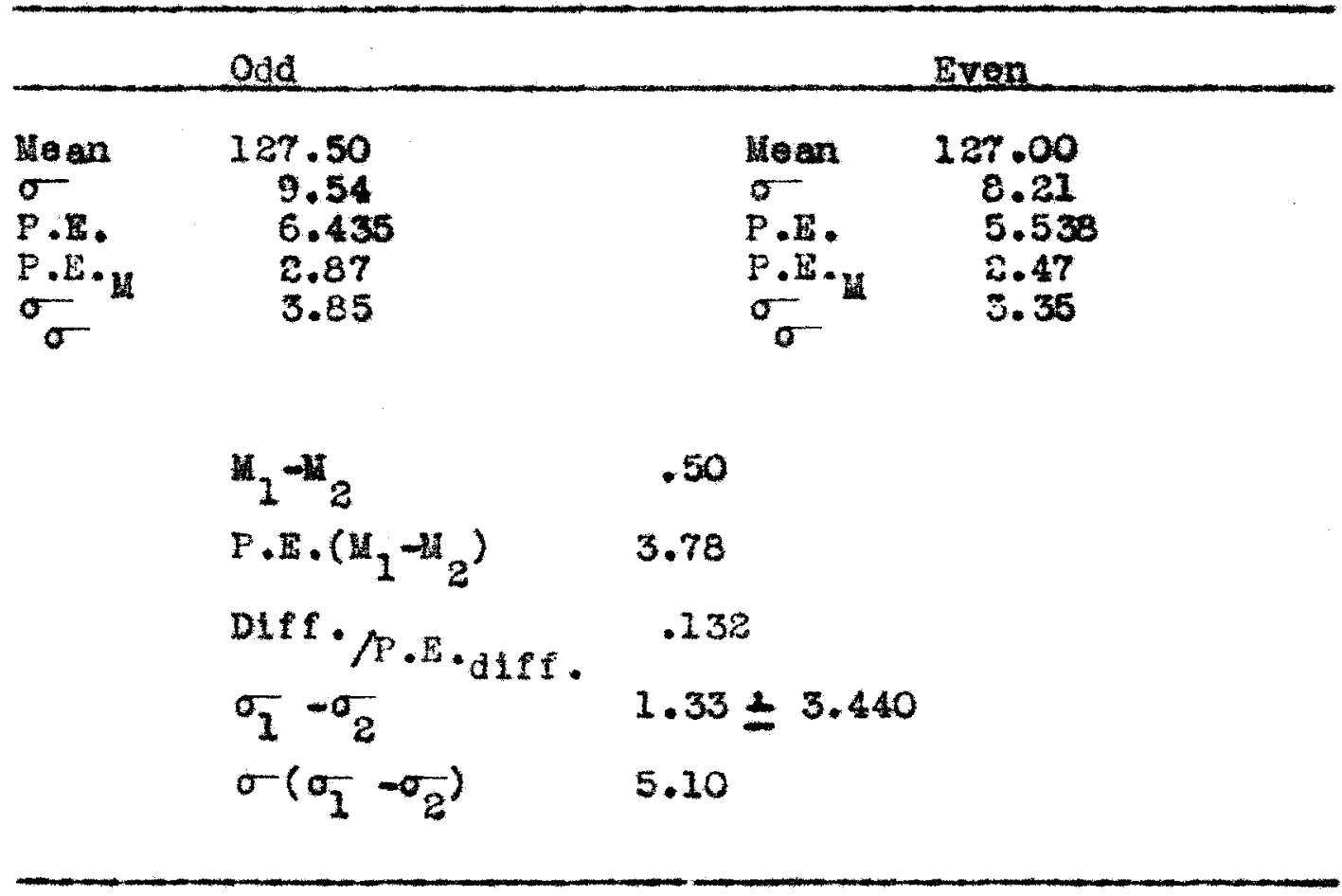

The diference between means $15-.50$. This difference divided by its probable error is .132 and 18 not gignificant.

The difference between standard deviations 1 s 1.33 with probable arror of $\$ 3.440$ and 2 s not Bignificant. 


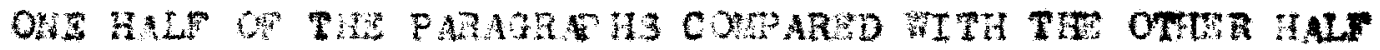
POR SCORS

BOOK II

Qur Nation's Harllage - Hallock and Frante

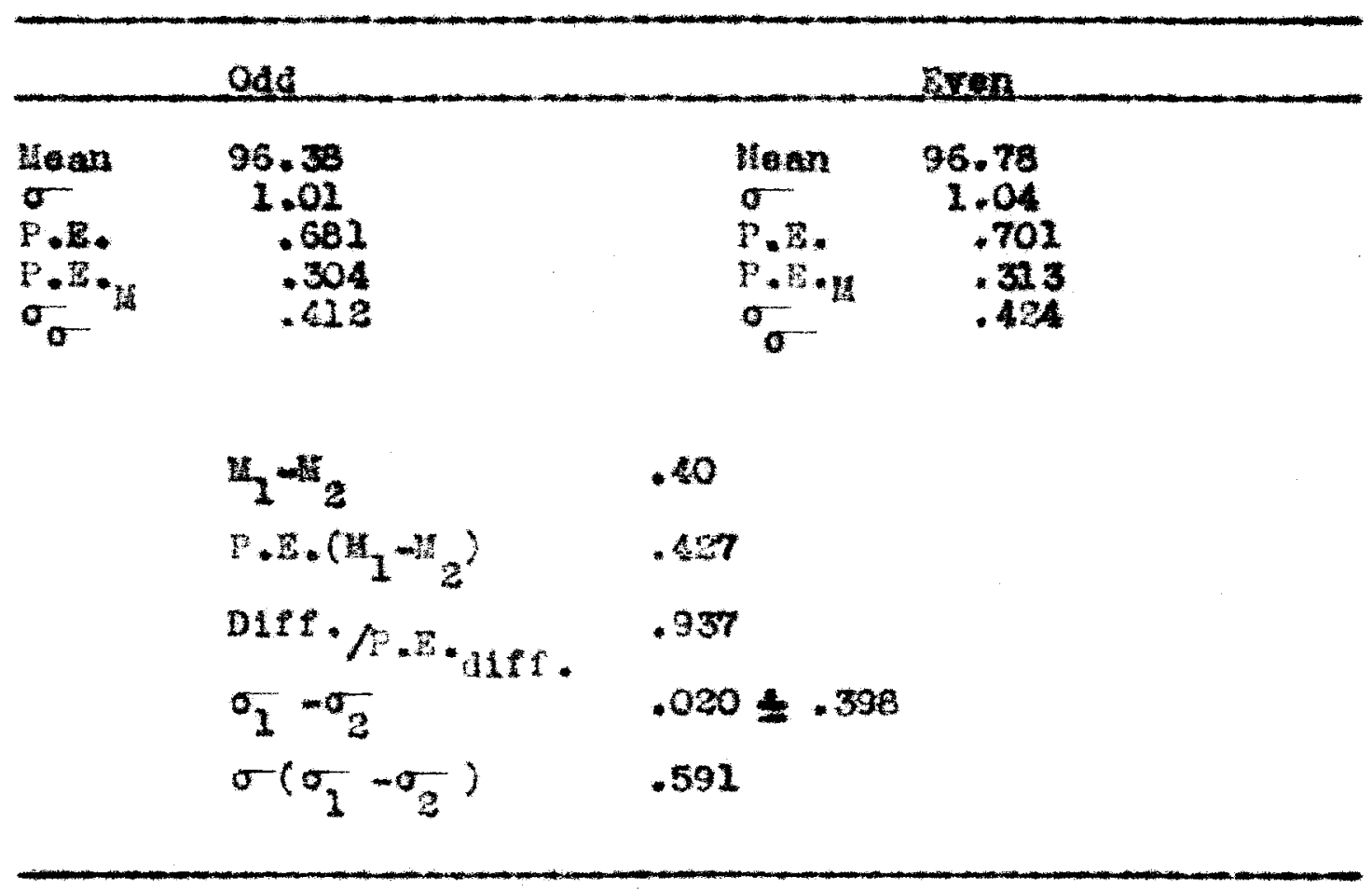

The differance between means is .40. This difference alwidad by its probable error is .937 and is not algnifloant.

The diftarence betwean standard devlationa 1 s. .020 3t th a probable error of $\neq$. 393 , whioh is a signifloant differance in al aperation. 
TABLIE XXX

ONE HALF OR THE PARAGRAPIS COMPARED WTTH THE OTHER HALF FOR SCORES

\section{BOOK III}

The old World Begimnings of Americs - Kelty

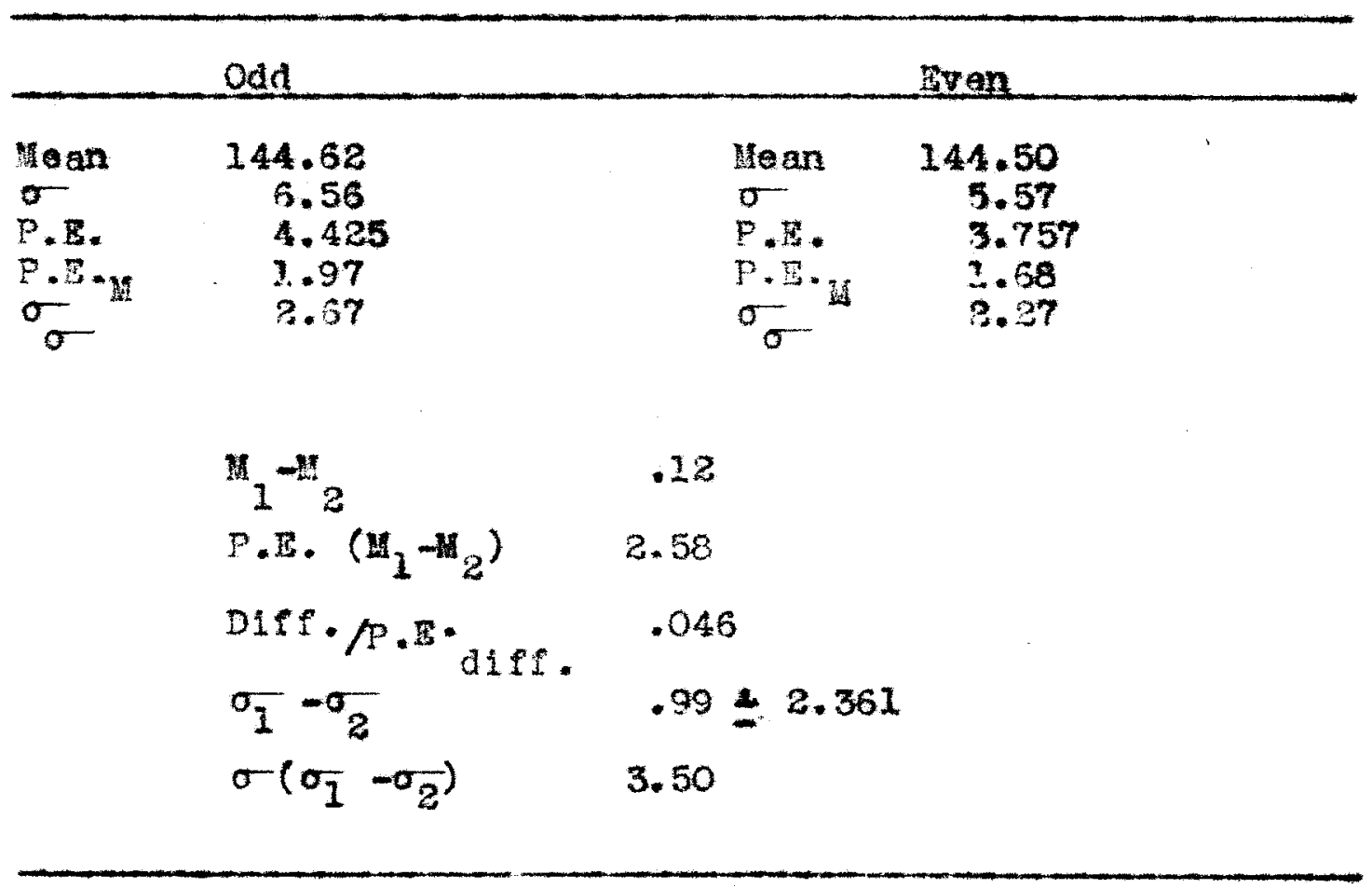

The difference between means is .12. This difference divided by 1 ts probable error $1 \mathrm{~s} .046$ and is not significant.

The difference between standard deviations is .99 with a probable error of \pm 2.361 whloh $1 \mathrm{~s}$ not a gignticant alferenos. 
TABLE XXXI

ONE HALF OT TH PARAGRATHS COPARED WITH THE OTHE HALF FOR SCORES

BOOK IV

The Amerioan People and Their old Forld Anceatorg-Vollintine

\begin{tabular}{|c|c|c|c|}
\hline & Odd & & Even \\
\hline \multirow[t]{2}{*}{$\begin{array}{l}\text { Mean } \\
\sigma \\
P \cdot \bar{E} . \\
\mathcal{P} \cdot \bar{B} \cdot \\
\sigma \\
\sigma\end{array}$} & $\begin{array}{c}106.62 \\
8.74 \\
5.895 \\
2.53 \\
3.56\end{array}$ & $\begin{array}{l}\text { Hean } \\
\sigma \\
P \cdot E . \\
\text { P.E. } \\
\sigma_{\sigma}\end{array}$ & $\begin{array}{c}106.75 \\
8.45 \\
5.699 \\
3.54 \\
3.45\end{array}$ \\
\hline & $\begin{array}{l}n_{1}=n_{2} \\
P \cdot \Omega \cdot\left(n_{1}-n_{2}\right) \\
\text { Diff.p.E. } \\
\sigma_{1}-\sigma_{2} \\
\sigma\left(\sigma_{1}-\sigma_{2}\right)\end{array}$ & $\begin{array}{l}.13 \\
3.65 \\
.035 \\
.29=3.1 .97 \\
4.740\end{array}$ & \\
\hline
\end{tabular}

The difference between means is .13. This difference divided by its probable orror is .035 and $1 \mathrm{~s}$ not signifleant.

The difference between standard deviations is .29 with a probable error of 13.197 which is not algnificant. 
TABL? XXXII

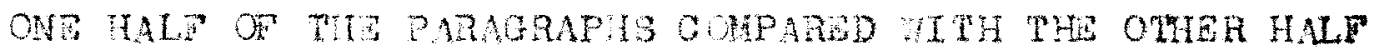
FOR GCORES

\begin{tabular}{|c|c|c|c|}
\hline \multicolumn{4}{|c|}{ BOOK $\mathrm{v}$} \\
\hline & Odd & & Even. \\
\hline 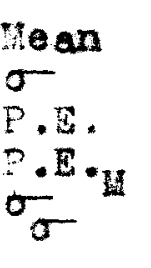 & $\begin{array}{c}127.87 \\
8.59 \\
5.851 \\
3.51 \\
3.54\end{array}$ & $\begin{array}{l}\text { Hean } \\
\sigma \\
\mathrm{P} \cdot \mathrm{B} \\
\mathrm{P} \cdot \mathrm{E} \cdot \mathrm{H} \\
\sigma \sigma\end{array}$ & $\begin{array}{c}123.75 \\
8.42 \\
5.579 \\
3.53 \\
3.43\end{array}$ \\
\hline & $\begin{array}{l}M_{1}-w_{2} \\
P \cdot E \cdot\left(M_{1}-H_{2}\right) \\
\text { Diff. /F.E. diff. } \\
\sigma_{1}-\sigma_{2} \\
\sigma\left(\sigma_{1}-\sigma_{2}\right)\end{array}$ & $\begin{array}{l}.12 \\
3.63 \\
.330 \\
.27 \pm 3.318 \\
4.92\end{array}$ & \\
\hline
\end{tabular}

The difference between means is .12 . This difference divided by ite probable error is .330 and is not signifioant.

The difference between the standard deviations is .27 with a probable error of $=3.318$ which is not significant. 
Tables XXXIII, XXXIV, XXXV, XXXVI, and XXXVII, pages 117 to 121, give the summary of the comparisons of the two halres of the selections for each book for:

1. Number of scntences to the paragraph

2. Number of phrases to the paragraph

3. Number of words to the gentence

4. Number of words to the phrase

5. Score on tests of comprehension

6. Tords beyond 6047

The statistical analysis $F$ or each of the above $\mathbf{s i x}$ varlables incitides:

a. Difference between means

b. Probable error of the ditfurence between means

c. Difference between means divided by their probable exror

d. Difference between standard deviations

e. Standard errors of the dicference butween standard deviations

f. Probable error of the staildard error of the difference between standard deviations

The disoussion below the table of sumaries $f$ or each book gives the conparison of the means and standard deviations. It also states whether the differenees between the means and dispersions of the $\approx 1 \%$ palrs of variables are significant. 
TABLE XXXIII

SUMMARY OF THF ODD PARAGRAPHS COUPARED WITH THE EVEN PARAGRAPHS TO DETZRMINE HHETHER THE THO HALVES ARE REPRESENTATIVR OF BOOK I\%

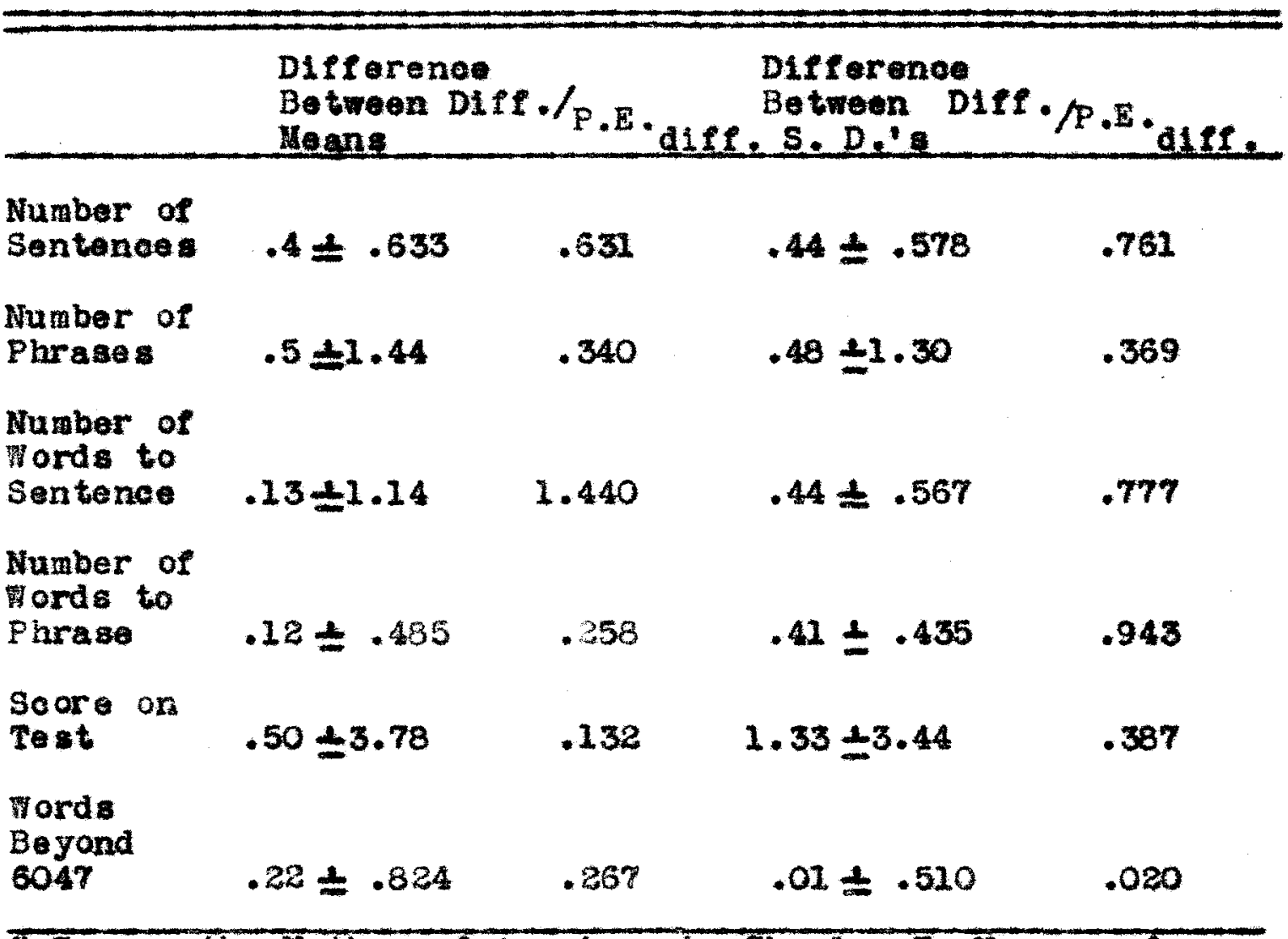

Europe the 韭other of Ameriag, by Charles F. Horne and OIIre Buoks. New York, Amerloan Book Company, 1931.

The difference betwoen the means together th their probable errors are given in the first column. The differenoes divided by their probable errors are given in the second oolumn. If a critical ratio ia less than 3.00 , the difference is not aignif toant.

The differenoes between the standard deviations together with their probable errors are given in the third colum; the differences between standard deviations divided by their probable errors in the fourth column. If a difference is less than three times its probable error it is not ahgnifi- 


\section{TABLE XXXIV}

SUVMARY OF THE ODD PARAGRAPHS COAPARED VITH TIE EVEN

PARAGRAPHS TO DETERUINE WIETIER TIE TWO TALVES ARE

REPRESENTATIVE OF BOOK II

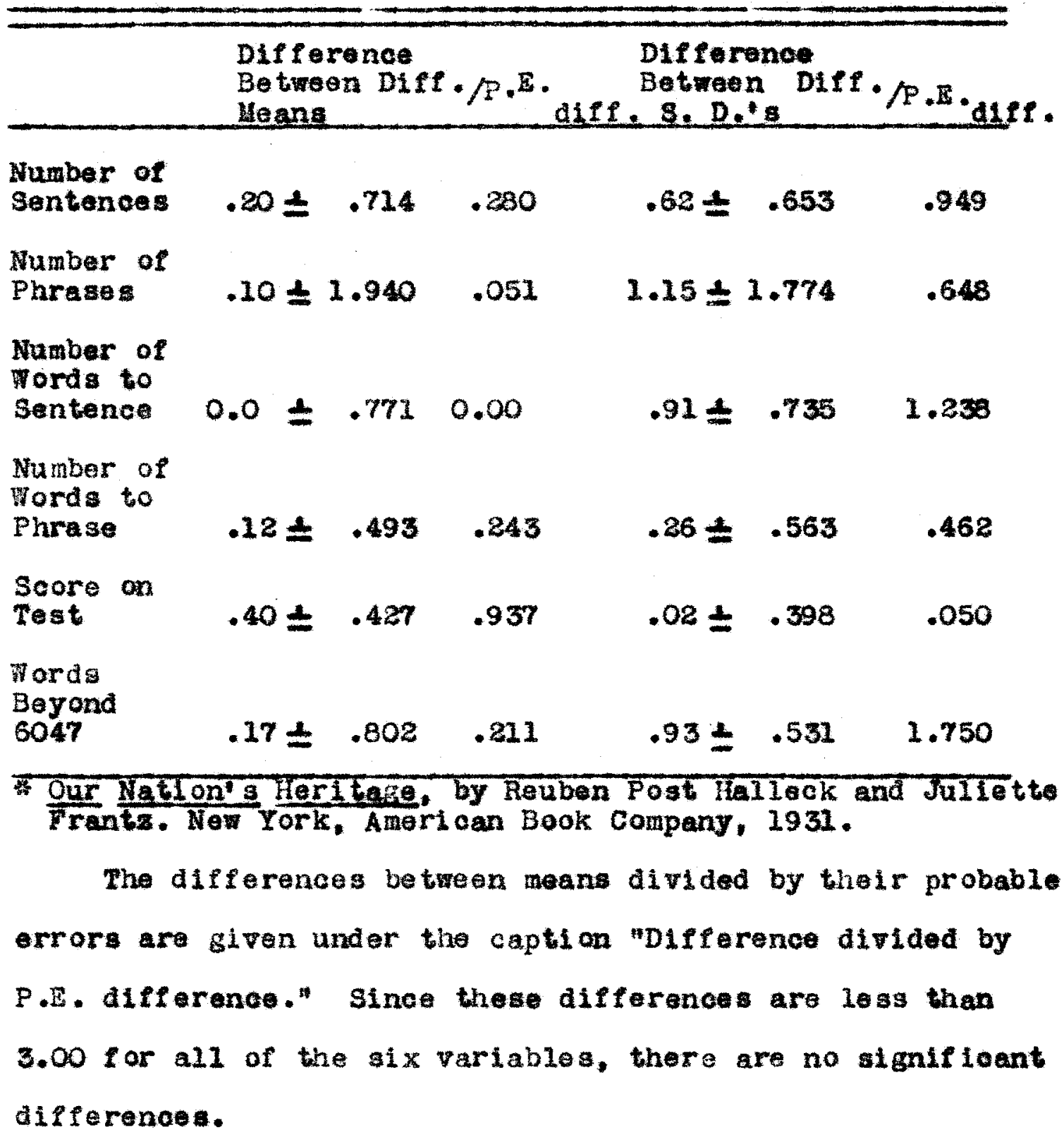

The alfference between standard deviations together with their probable errors are given under the caption "Difference between Standard Deviations." Since these differences are less than three thes their probable errors they are not significant. 


\section{TABLE XXXV}

SUMRARY OF THE ODD PARAGRAPISS COUPARED YIT TH THE EVEN PARAGRAPIS TO DETERIINE WIETHER THE THO HALVES ARE REPRESENTATIVE OF BOOK III*

\begin{tabular}{|c|c|c|c|c|c|c|}
\hline \multirow[b]{2}{*}{$\begin{array}{l}\text { Number of } \\
\text { Sentences }\end{array}$} & \multicolumn{2}{|c|}{$\begin{array}{l}\text { Differenoe } \\
\text { Between Dif } \\
\text { Heane }\end{array}$} & \multicolumn{3}{|c|}{$\begin{array}{l}\text { Dlf ference } \\
\text { Between Dif } \\
\text { S. D.'B } \\
\end{array}$} & \multirow{2}{*}{$\frac{-P \cdot E \cdot d L t e}{.520}$} \\
\hline & $.25 \leqslant$ & .529 & .472 & $.25 \pm$ & .482 & \\
\hline $\begin{array}{l}\text { Number of } \\
\text { Phrase } 8\end{array}$ & $1.30 \pm$ & 1.571 & .820 & $.66 \pm$ & 1.457 & .453 \\
\hline $\begin{array}{l}\text { Wumber of } \\
\text { Tords to } \\
\text { Sentence }\end{array}$ & $1.00 \pm$ & 1.180 & .845 & $.18 \neq$ & 1.052 & .171 \\
\hline $\begin{array}{l}\text { Number of } \\
\text { Torde to } \\
\text { Phrase }\end{array}$ & $0.0 \leq$ & .263 & 0.00 & $0.0 \pm$ & .256 & 0.0 \\
\hline $\begin{array}{l}\text { Score on } \\
\text { Test }\end{array}$ & $.12 \leqslant$ & 2.58 & .046 & $.99 \pm$ & 2.361 & .418 \\
\hline $\begin{array}{l}\text { Words } \\
\text { Beyond } \\
6047\end{array}$ & $.47 \pm$ & .718 & .654 & $.35 \pm$ & .477 & .735 \\
\hline
\end{tabular}

* The old world Beglaninge of Ameriag by Hary C. KeIty. Ner York, Ginn and Company, 1932.

The differences between means divided by their probablo errors are given under the caption "Difference divided by P.E. difference." Since these differences are less than 3.00 for all of the gix variables, they are not gi gnificant. The difference between standard deviations together with their probable errors are given under the eaption "Difference between Standard Deviations." Since these differences are less than three times their probable errors they are not significant. 
TABL $2 \times X X V I$

SUMMARY OF THE ODD PARAGRAPHS COUPARED WITH THE EVEN PARAGRAPIS TO DETERIINE WHETIER TIE TO HALVES ARE REPREBENTATIVE OF BOOK IV*

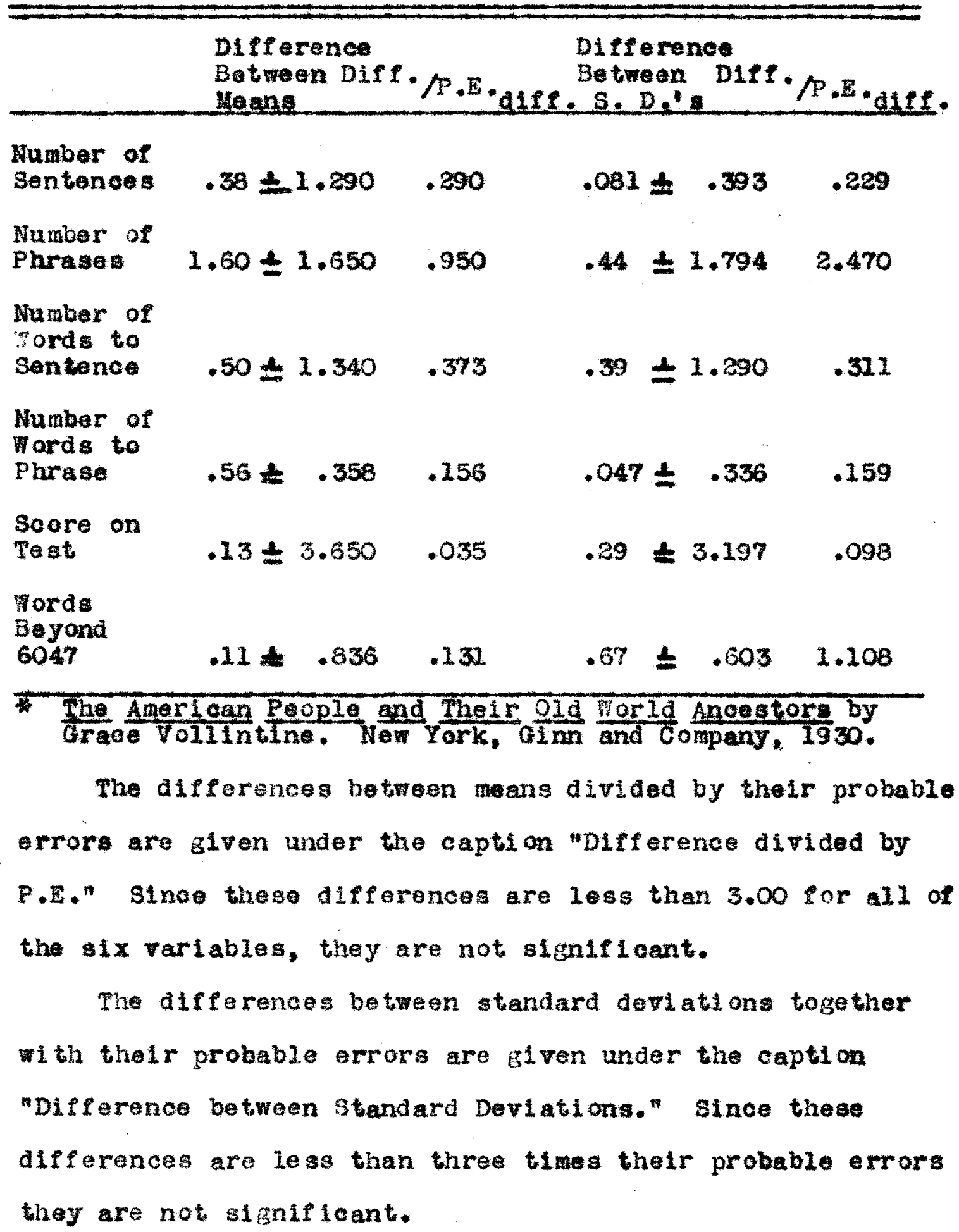




\section{TABLE XXXVII}

SUHAARY OT THE ODD PARAGRAPHS COMPARED WITH THE EVEN PARAGRAPUS TO DETEREINE WILTIER TIIE TWO HALVES ARE REPRESENTATIVE OF BOOK V\%

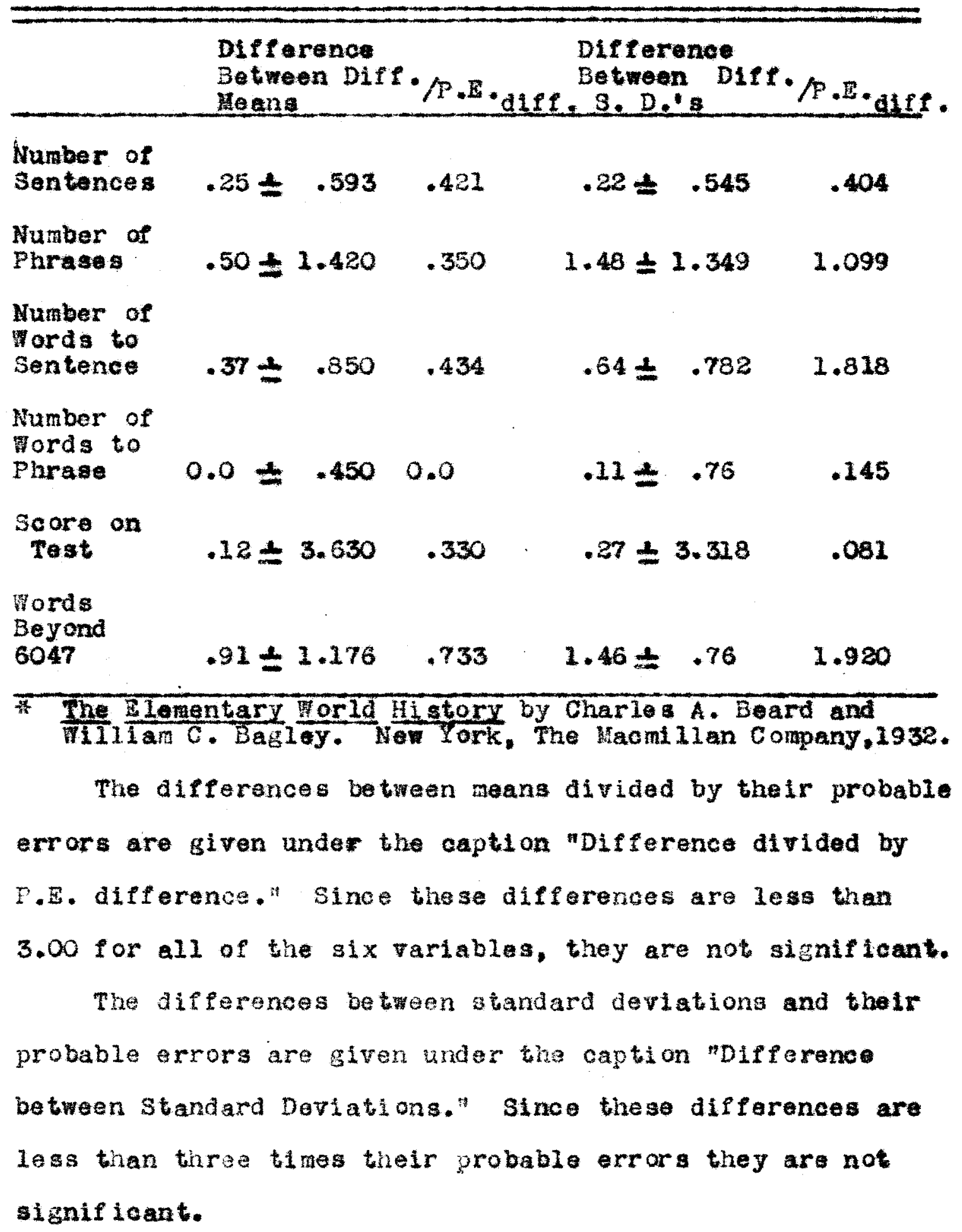


SULAARY FOR THE ANALYSIS OF THE DATA TO DRTHRUINE THE DEGRE TO WIICH THE SAUPLINGS ARE REPRESENTATIVE OF THE BOOK FROU WHICH THEY ARE TAKEN

In order to determine the degree to which the seventeen selections from each book vere in keeping with the joint opinion of the six teachers who selected them, statistical measures of comparison wero used.

The odd-numbered paragraphs were compared wth the even-numbered paragraphs.

Comparison of the twa halves of the selections were made $f$ or:

1. Number of words lying beyond 6047

2. Number of worda to the sentenos (eive letters to the word)

3. Number of words to the phrase (ive letters to the word)

4. Number of sentenoes to the parazraph

5. Number of phrases to the paragraph

6. Degree of accuracy with wiah the selectione were read and the questions answered

Each book was compared for significant difference between its means and standara deviations for the six varlables glven above.

The statistioal comparisons showed no signiflcant difierences between means nor standard devlations for any of the five history books, from which we may conolude that the samplings chosen by the six judges are truly representative of the books as wholes. 
ANALYSIS OF THE FIVE SUPPLERENARY

IISTORY BOOKS FOR VOCADULARY AND

BEITTENCE - AND PHRASE-LENGTH 


\section{CHAPTER $\mathbf{V}$}

ANALYSIS OF THE FIVE SUPPLEIMNTARY HISTORY

BOOKS FOR VOCABULARY AND SENTENCE - AND

PIRASE-LENGTH

\section{A. Vocabulary Analyals}

The rocabulary analysis ia made for the fire history books by parazraphs for each milliclassification of Thorndike's Scale ${ }^{1}$ and for the number of words lying beyond 10,000 .

Table XXXVIII, (page 126) shows the word count and olassification of words from Book I, Europe the Mother of America, by Horne and Buoks. The paragraphs are numbered at the extreme left in vertical order. To the right are the scale positions for all words occurring in the paragraph. At the foot of the table are shown the total number of words for the seventeen parazrapis and the per cent for the totals.

In tabulating the words, every word was counted, no separate categories being ade for different or recurring words. Table XXXVIII, (page 126), means, then, that there are 1356 running words in the seventeen paragraphs taken from Book I. 1075 of the words, or 79.4 per cent of the 1356, lie in the ilrst rank or below 1000; 117 words, or 8.6 per cent, lie between 1001 and 2000; and 23, or 1.7 per cent of the words, lie beyond 10,000 .

1. Thorndike, E. L., The Teachers Word Book of Ten Thousand Torda. 1923, p.i11. 
of 74 words in Paragraph No. 1:

$\begin{array}{rrrr}59 & 1 i e & \text { between } & 2 \text { and } 1000 \\ 6 & " & " & 1001 \text { and } 2000 \\ 4 & " & " & 2001 \text { and } 3000 \\ 3 & " & " & 3001 \text { and } 4000 \\ 1 & " & " & 4001 \text { and } 5144 \\ 1 & n & 7 & 6048 \text { and } 6618\end{array}$

Paragraph No. 1, then, has no words beyond 10,000 and only one word beyond 3047 , that in the next rank of 6048-6618. 69 of the word lie belor 3000 . Since Gates ${ }^{2}$ uses the firat 2500 words on the Thorndike Soale as a range for primery grades, the words in Paragraph No. 1 appear to be words in very common use.

Paraigraph No. 12 has 65 of its 78 words lying bolow 1000, but also shows one word beyond 10,000 and one word beyond 6047 . These two words mean that 2.5 per cent of the word in Paragraph No. 12 lie beyond the range of words comonly used by twelve-year-old children, 3 and, if they are key words, they may affect the pupils' understanding of that paragraph. The words are "monastertes," and "patios," "patio" being defined as "a court."

Paragraph No. 7 has 33 mords, or 70.1 per cert of 1 ts vocabulary, below 1000 , and 4 words, or 8.6 per cent of Its vocabulary, beyond 6047 .

Paragraph No. 17 shows five words beyond 6047, whi ah means that 8.9 per cent of its vocabulary is not frequently 2. Gates, Arthur I, The Construction of a Reading Voca-
bulary for the Primary Grades." Teachers College Record,
Volume 27, 1926 , p. 4.
3erman, L. M. The isagurement of Intelligence. 1926,
p. 226. 
used by twelve-year-old chlidren.

The range of words in other parazraphs is given under their rank-heading.

Table XXXIX, (page 127), shows the word count by ranks 1 rom Book II. There are 173 more words in the sampling from Book II with the range of vocabulary lylng somewhat higher than Book I.

Table XL, (page 128), shows Book III to have a low range of voabulary. Paragraphs Nos. 5 and 6 , however, contain mords beyond the 10,000 rank. Parazraph No. 5 is a disoussion of the "Vikings in Burope," and Paragraph No. 6 is gbout the "Nortiman on the Mainland of America." These paragraphs ahow uncomon words for all the samples wi th Book III pling up five words for Paragraph No. 5 and e ight words or Paragraph No. 6.

Table XLI, (Page 129), shows the word count for Book IV and Table XIII, (page 130), for Book V. The word range of Book IV shows 78.8 per cent of the words below the firgt 1000, but, as seen under Rank 13, a large number of yords are cleariy unugual to twelve-year-old children. In Table XLII, Book $V$ has 9 words beyond 10,000 in the second paragraph. This topic, "Teutons," was disoussed in Books II and III with one uncommon word; in Book IV with two uncomron words; and in Book I with none. The general range of vocabulary for Book $v$, homever, is gimllar to that of Book II. 
TABLE XXXVIII

VOCABULARY ANALYSIS BY PARAGRAPHS FOR BOOK I, EUROPE THE MOTHER OF AMERICA, BY HORNE - BUCKS

\begin{tabular}{|c|c|c|c|c|c|c|c|c|c|c|c|c|c|c|}
\hline Paragraph & 1 & 2 & 3 & 4 & 5 & 3 & & 8 & g. & 10 & 11 & 12 & 13 & \pm \\
\hline $\begin{array}{r}1 \\
2 \\
3 \\
4 \\
5 . \\
6 \\
7 \\
8 \\
9 \\
10 \\
11 \\
12 \\
13 \\
14 \\
15 \\
16 \\
17\end{array}$ & $\begin{array}{r}59 \\
68 \\
60 \\
55 \\
43 \\
72 \\
33 \\
80 \\
37 \\
81 \\
40 \\
65 \\
45 \\
107 \\
58 \\
81 \\
91\end{array}$ & $\begin{array}{r}6 \\
10 \\
3 \\
9 \\
6 \\
8 \\
6 \\
5 \\
8 \\
5 \\
5 \\
33 \\
4 \\
12 \\
11 \\
7 \\
9\end{array}$ & $\begin{array}{l}4 \\
2 \\
0 \\
3 \\
1 \\
2 \\
2 \\
3 \\
5 \\
3 \\
4 \\
4 \\
4 \\
4 \\
4 \\
6 \\
6\end{array}$ & $\begin{array}{l}3 \\
3 \\
1 \\
2 \\
1 \\
3 \\
0 \\
2 \\
0 \\
4 \\
0 \\
2 \\
1 \\
0 \\
1 \\
1 \\
6\end{array}$ & $\begin{array}{l}1 \\
0 \\
1 \\
1 \\
0 \\
0 \\
0 \\
1 \\
0 \\
2 \\
0 \\
2 \\
2 \\
0 \\
0 \\
0 \\
2\end{array}$ & $\begin{array}{l}0 \\
0 \\
0 \\
0 \\
0 \\
0 \\
2 \\
0 \\
0 \\
0 \\
1 \\
0 \\
0 \\
2 \\
0 \\
1 \\
0\end{array}$ & $\begin{array}{l}0 \\
0 \\
1 \\
1 \\
1 \\
0 \\
0 \\
0 \\
0 \\
1 \\
0 \\
0 \\
0 \\
3 \\
2 \\
0 \\
0\end{array}$ & $\begin{array}{l}1 \\
0 \\
0 \\
0 \\
0 \\
1 \\
0 \\
0 \\
0 \\
0 \\
1 \\
0 \\
0 \\
0 \\
0 \\
0 \\
0\end{array}$ & $\begin{array}{l}0 \\
0 \\
0 \\
1 \\
0 \\
1 \\
2 \\
0 \\
0 \\
0 \\
0 \\
0 \\
1 \\
3 \\
0 \\
1 \\
1\end{array}$ & $\begin{array}{l}0 \\
0 \\
0 \\
0 \\
0 \\
0 \\
2 \\
1 \\
1 \\
1 \\
1 \\
0 \\
0 \\
0 \\
0 \\
1 \\
0 \\
2\end{array}$ & $\begin{array}{l}0 \\
0 \\
0 \\
0 \\
0 \\
0 \\
0 \\
0 \\
0 \\
0 \\
0 \\
0 \\
1 \\
0 \\
2 \\
0 \\
0 \\
0\end{array}$ & $\begin{array}{l}0 \\
0 \\
1 \\
1 \\
0 \\
0 \\
0 \\
0 \\
0 \\
0 \\
0 \\
1 \\
0 \\
0 \\
0 \\
0 \\
0\end{array}$ & $\begin{array}{l}0 \\
1 \\
1 \\
3 \\
1 \\
6 \\
0 \\
1 \\
0 \\
0 \\
0 \\
1 \\
1 \\
4 \\
2 \\
0 \\
2\end{array}$ & $\begin{array}{c}\text { *key: } \\
\text { 1. } 1-1000 \\
\text { 2. } 1001-2000 \\
\text { 3. } 2001-3000 \\
\text { 4. } 3001-4000 \\
\text { 5. } 4001-5144 \\
\text { 6. } 5145-5544 \\
\text { 7. } 5545-6047 \\
\text { 8. } 6048-6518 \\
\text { 9. } 6519-7262 \\
\text { 10. 7263-8145 } \\
\text { 11. } 8146-9190 \\
\text { 12. } 9191-10000 \\
\text { 13. Beyond } \\
10,000\end{array}$ \\
\hline $\begin{array}{l}\text { Total } \\
\text { Per Cent }\end{array}$ & $\begin{array}{l}1075 \\
79.4\end{array}$ & $\begin{array}{l}117 \\
8.6\end{array}$ & $\begin{array}{l}57 \\
4.2\end{array}$ & $\begin{array}{l}30 \\
2.2\end{array}$ & $\begin{array}{l}12 \\
.9\end{array}$ & $\begin{array}{r}6 \\
.5\end{array}$ & $\begin{array}{r}9 \\
.6\end{array}$ & $\begin{array}{r}3 \\
.2\end{array}$ & $\begin{array}{l}10 \\
.7\end{array}$ & $\begin{array}{r}8 \\
.6\end{array}$ & $\begin{array}{r}3 \\
.2\end{array}$ & $\begin{array}{r}3 \\
.2\end{array}$ & $\begin{array}{r}23 \\
1.7\end{array}$ & 1356 \\
\hline
\end{tabular}


TABLE XXXIX

VOCABULART ANALYSIS BY PARAGRAPHS FOR BOOK II, OUR NATION'S IIERITAGE, BY IIALLECK - FRANTZ

\begin{tabular}{|c|c|c|c|c|c|c|c|c|c|c|c|c|c|}
\hline Paragraphs & 1 & 2 & 3 & 4 & 5 & 6 & $\begin{array}{l}\text { Word } \\
7\end{array}$ & $\begin{array}{l}\text { Count } \\
8\end{array}$ & 9 & 11 & 12 & 13 & 4 \\
\hline $\begin{array}{r}1 \\
2 \\
3 \\
4 \\
5 \\
6 \\
7 \\
8 \\
9 \\
10 \\
11 \\
12 \\
13 \\
14 \\
15 \\
16 \\
17\end{array}$ & $\begin{array}{r}127 \\
51 \\
72 \\
31 \\
80 \\
58 \\
40 \\
77 \\
29 \\
56 \\
73 \\
69 \\
69 \\
103 \\
67 \\
67 \\
92\end{array}$ & $\begin{array}{r}20 \\
9 \\
6 \\
5 \\
10 \\
4 \\
5 \\
16 \\
4 \\
3 \\
7 \\
4 \\
3 \\
12 \\
12 \\
8 \\
9\end{array}$ & $\begin{array}{r}7 \\
4 \\
5 \\
2 \\
3 \\
3 \\
1 \\
15 \\
3 \\
6 \\
9 \\
6 \\
5 \\
3 \\
2 \\
4 \\
5\end{array}$ & $\begin{array}{l}3 \\
0 \\
2 \\
2 \\
1 \\
3 \\
3 \\
0 \\
3 \\
7 \\
3 \\
1 \\
1 \\
3 \\
1 \\
1 \\
2\end{array}$ & $\begin{array}{l}3 \\
1 \\
0 \\
0 \\
4 \\
1 \\
0 \\
1 \\
3 \\
3 \\
1 \\
3 \\
1 \\
3 \\
2 \\
2 \\
2\end{array}$ & $\begin{array}{l}3 \\
0 \\
0 \\
0 \\
1 \\
0 \\
2 \\
0 \\
1 \\
0 \\
1 \\
1 \\
1 \\
0 \\
0 \\
0 \\
0\end{array}$ & $\begin{array}{l}1 \\
1 \\
0 \\
1 \\
0 \\
0 \\
1 \\
0 \\
1 \\
0 \\
0 \\
0 \\
0 \\
6 \\
0 \\
1 \\
1\end{array}$ & $\begin{array}{l}0 \\
0 \\
0 \\
0 \\
1 \\
0 \\
0 \\
0 \\
0 \\
0 \\
1 \\
0 \\
1 \\
0 \\
0 \\
0 \\
0\end{array}$ & $\begin{array}{l}0 \\
0 \\
0 \\
0 \\
1 \\
0 \\
2 \\
3 \\
2 \\
1 \\
0 \\
0 \\
0 \\
0 \\
0 \\
1 \\
1\end{array}$ & $\begin{array}{l}0 \\
0 \\
0 \\
0 \\
1 \\
0 \\
0 \\
0 \\
0 \\
0 \\
0 \\
0 \\
0 \\
1 \\
0 \\
0 \\
0\end{array}$ & $\begin{array}{l}0 \\
0 \\
0 \\
0 \\
0 \\
1 \\
0 \\
1 \\
0 \\
0 \\
0 \\
0 \\
0 \\
0 \\
0 \\
0 \\
0\end{array}$ & $\begin{array}{l}2 \\
1 \\
2 \\
1 \\
4 \\
5 \\
0 \\
4 \\
2 \\
1 \\
2 \\
0 \\
1 \\
0 \\
0 \\
2 \\
3\end{array}$ & $\begin{array}{l}\text { Hey: } \\
\text { 1. } 1-1000 \\
\text { 8. } 1001-2000 \\
\text { 3. } 2001-3000 \\
\text { 4. } 3001-4000 \\
\text { 5. } 4001-5144 \\
\text { 6. } 5145-5544 \\
\text { 7. } 5545-6047 \\
\text { 8. } 6048-6618 \\
\text { 9. } 6519-7262 \\
\text { 10. } 7263-8145 \\
11.8146-9190 \\
17.9191-10000 \\
13 . \quad \text { Beyond } \\
10,000\end{array}$ \\
\hline $\begin{array}{l}\text { Total } \\
\text { Por Cent }\end{array}$ & $\begin{array}{l}1161 \\
78.0\end{array}$ & $\begin{array}{l}137 \\
9.0\end{array}$ & $\begin{array}{r}83 \\
5.5\end{array}$ & $\begin{array}{r}36 \\
2.4\end{array}$ & $\begin{array}{r}30 \\
2.0\end{array}$ & $\begin{array}{l}10 \\
.7\end{array}$ & $\begin{array}{l}12 \\
.8\end{array}$ & $\begin{array}{r}3 \\
-2\end{array}$ & $\begin{array}{l}11 \\
.7\end{array}$ & $\begin{array}{r}2 \\
.1\end{array}$ & $\begin{array}{r}2 \\
.1\end{array}$ & $\begin{array}{r}31 \\
2.1\end{array}$ & 1529 \\
\hline
\end{tabular}


TABLE XL

VOCABULARY ANALYSIS BY PARAGRAPHS FOR BOOK III, THE OLD WORLD BEGINUINGS OF ALERICA, BY KELTY

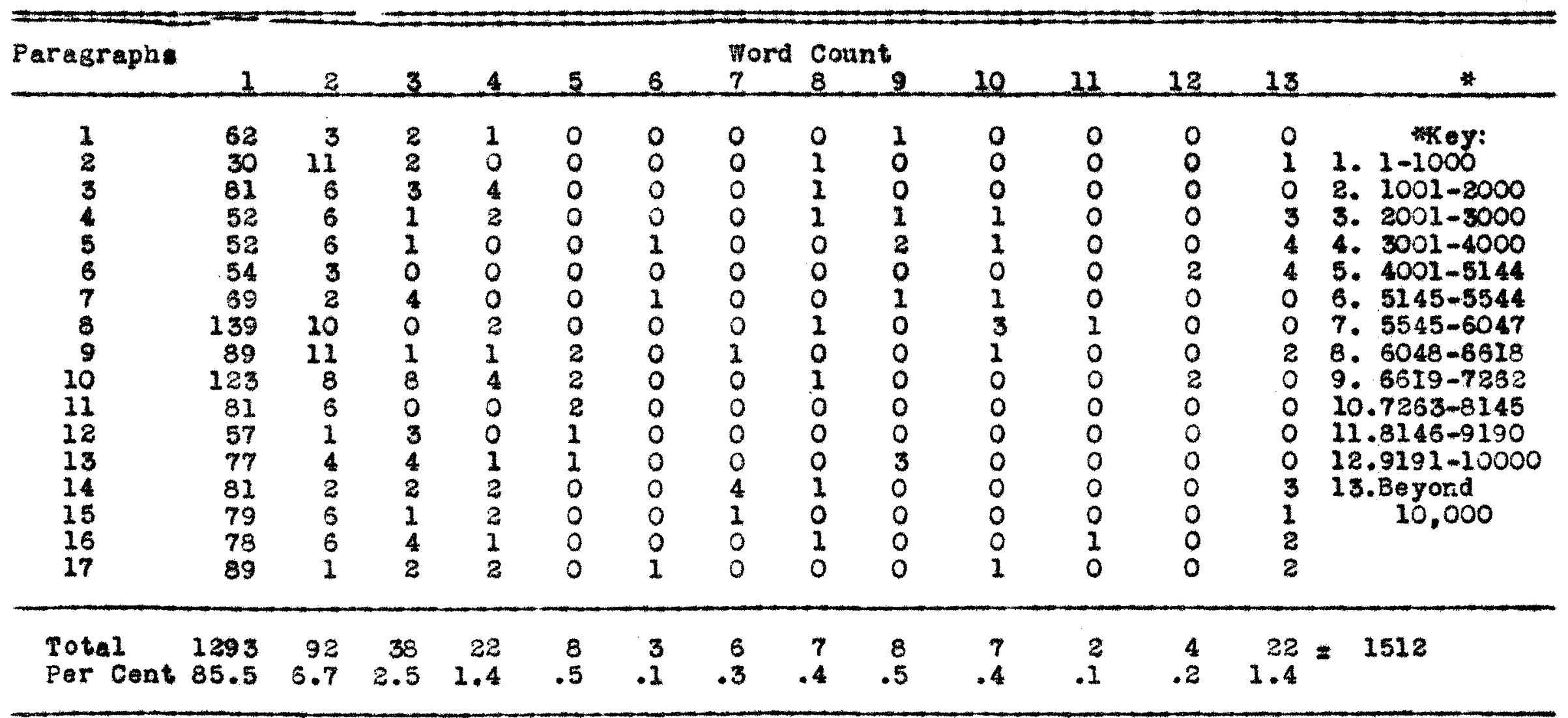


TABLE XII

VOCABULARY ANALTSIS BY PARAGRAFHS FOR BOOK IV, TUE AMERICAN PEOPLE AND TIEIR OLD WORLD ANCESTORS BY VOLLINTINE

\begin{tabular}{|c|c|c|c|c|c|c|c|c|c|c|c|c|c|c|}
\hline Paragraphs & 1 & 2 & 3 & 4 & 5 & 6 & $\begin{array}{c}\text { Word } \\
7 \\
\end{array}$ & $\begin{array}{c}\text { Count } \\
8\end{array}$ & 9 & 10 & 11 & 12 & 13 & $*$ \\
\hline $\begin{array}{c}1 \\
2 \\
3 \\
4 \\
5 \\
6 \\
7 \\
8 \\
9 \\
10 \\
11 \\
12 \\
13 \\
14 \\
15 \\
16 \\
17\end{array}$ & $\begin{array}{r}100 \\
88 \\
89 \\
82 \\
84 \\
80 \\
105 \\
71 \\
60 \\
84 \\
67 \\
66 \\
101 \\
123 \\
85 \\
66 \\
83\end{array}$ & $\begin{array}{r}15 \\
7 \\
8 \\
9 \\
6 \\
8 \\
7 \\
6 \\
13 \\
10 \\
9 \\
7 \\
11 \\
10 \\
11 \\
8 \\
7\end{array}$ & $\begin{array}{l}2 \\
4 \\
3 \\
3 \\
1 \\
0 \\
5 \\
8 \\
6 \\
7 \\
5 \\
4 \\
5 \\
6 \\
9 \\
8 \\
8\end{array}$ & $\begin{array}{l}3 \\
0 \\
1 \\
1 \\
1 \\
3 \\
2 \\
0 \\
1 \\
0 \\
2 \\
0 \\
3 \\
1 \\
3 \\
2 \\
4\end{array}$ & $\begin{array}{l}3 \\
3 \\
1 \\
1 \\
1 \\
2 \\
2 \\
1 \\
0 \\
0 \\
1 \\
2 \\
1 \\
2 \\
2 \\
0 \\
1\end{array}$ & $\begin{array}{l}0 \\
1 \\
0 \\
0 \\
0 \\
0 \\
2 \\
1 \\
0 \\
0 \\
2 \\
0 \\
1 \\
1 \\
2 \\
0 \\
1\end{array}$ & $\begin{array}{l}0 \\
0 \\
3 \\
0 \\
0 \\
0 \\
3 \\
0 \\
1 \\
0 \\
0 \\
0 \\
0 \\
1 \\
0 \\
2 \\
1\end{array}$ & $\begin{array}{l}0 \\
2 \\
0 \\
1 \\
0 \\
2 \\
0 \\
0 \\
0 \\
0 \\
0 \\
0 \\
1 \\
1 \\
1 \\
1 \\
1\end{array}$ & $\begin{array}{l}0 \\
0 \\
1 \\
4 \\
1 \\
1 \\
1 \\
0 \\
0 \\
2 \\
0 \\
0 \\
0 \\
0 \\
0 \\
1 \\
2\end{array}$ & $\begin{array}{l}1 \\
0 \\
0 \\
1 \\
1 \\
1 \\
0 \\
2 \\
3 \\
0 \\
1 \\
0 \\
0 \\
0 \\
1 \\
1 \\
0\end{array}$ & $\begin{array}{l}0 \\
0 \\
0 \\
1 \\
0 \\
0 \\
0 \\
0 \\
0 \\
0 \\
0 \\
1 \\
0 \\
1 \\
0 \\
0 \\
1\end{array}$ & $\begin{array}{l}0 \\
1 \\
0 \\
0 \\
0 \\
0 \\
0 \\
0 \\
0 \\
0 \\
0 \\
0 \\
0 \\
0 \\
1 \\
0 \\
0\end{array}$ & $\begin{array}{l}0 \\
2 \\
4 \\
2 \\
5 \\
8 \\
4 \\
2 \\
1 \\
0 \\
2 \\
2 \\
4 \\
1 \\
4 \\
3 \\
1\end{array}$ & $\begin{array}{c}\text { skey: } \\
1.1-1000 \\
2.1001-2000 \\
3.2001-3000 \\
4.3001-4000 \\
5.4001-5144 \\
6.5145-5544 \\
7.5545-6047 \\
8.5048-8518 \\
9.6619-7252 \\
10.7253-8145 \\
11.8146-9190 \\
12.9191-10000 \\
13 . \text { Beyond } \\
10,000\end{array}$ \\
\hline $\begin{array}{l}\text { Total } \\
\text { Por cent }\end{array}$ & $\begin{array}{l}1434 \\
78.6\end{array}$ & $\begin{array}{l}152 \\
8.3\end{array}$ & $\begin{array}{r}84 \\
4.6\end{array}$ & $\begin{array}{r}27 \\
1.4\end{array}$ & $\begin{array}{r}23 \\
1.2\end{array}$ & $\begin{array}{r}11 \\
0.6\end{array}$ & $\begin{array}{r}11 \\
0.6\end{array}$ & $\begin{array}{l}10 \\
0.5\end{array}$ & $\begin{array}{l}13 \\
. .7\end{array}$ & $\begin{array}{r}12 \\
0.6\end{array}$ & 0.2 & 0.1 & $\begin{array}{r}45 \\
2.4\end{array}$ & $=1821$ \\
\hline
\end{tabular}


TABLE XLII

VOCABULARY ANALYSIS BY PARAGRAPHS FOR BOOK V, ELSMENTARY TORLD HISTORY, BY BEARD - BAGLEY

\begin{tabular}{|c|c|c|c|c|c|c|c|c|c|c|c|c|c|c|}
\hline Paragraph & \multicolumn{14}{|c|}{$6^{\text {Word Count }}$} \\
\hline $\begin{array}{r}1 \\
2 \\
3 \\
4 \\
5 \\
6 \\
7 \\
8 \\
9 \\
10 \\
11 \\
12 \\
13 \\
14 \\
15 \\
16 \\
17\end{array}$ & $\begin{array}{r}131 \\
59 \\
117 \\
85 \\
71 \\
67 \\
165 \\
102 \\
56 \\
85 \\
75 \\
54 \\
48 \\
90 \\
65 \\
46 \\
54\end{array}$ & $\begin{array}{r}25 \\
10 \\
13 \\
11 \\
6 \\
8 \\
16 \\
7 \\
12 \\
9 \\
9 \\
9 \\
8 \\
7 \\
6 \\
4 \\
7\end{array}$ & $\begin{array}{l}8 \\
6 \\
6 \\
6 \\
3 \\
1 \\
6 \\
4 \\
5 \\
8 \\
6 \\
5 \\
5 \\
2 \\
4 \\
4 \\
3\end{array}$ & $\begin{array}{l}3 \\
5 \\
3 \\
4 \\
5 \\
2 \\
6 \\
5 \\
0 \\
0 \\
4 \\
5 \\
0 \\
4 \\
2 \\
2 \\
5\end{array}$ & $\begin{array}{l}0 \\
2 \\
1 \\
0 \\
3 \\
2 \\
1 \\
3 \\
1 \\
0 \\
3 \\
1 \\
0 \\
1 \\
1 \\
2 \\
0\end{array}$ & $\begin{array}{l}0 \\
1 \\
0 \\
1 \\
0 \\
1 \\
0 \\
0 \\
0 \\
0 \\
1 \\
2 \\
0 \\
0 \\
0 \\
0 \\
0\end{array}$ & $\begin{array}{l}0 \\
1 \\
0 \\
0 \\
1 \\
2 \\
0 \\
1 \\
2 \\
0 \\
0 \\
0 \\
0 \\
0 \\
0 \\
0 \\
3\end{array}$ & $\begin{array}{l}0 \\
1 \\
0 \\
0 \\
0 \\
1 \\
0 \\
1 \\
0 \\
0 \\
1 \\
1 \\
0 \\
0 \\
0 \\
1 \\
0\end{array}$ & $\begin{array}{l}0 \\
1 \\
1 \\
2 \\
1 \\
1 \\
4 \\
2 \\
1 \\
1 \\
2 \\
0 \\
0 \\
0 \\
0 \\
1 \\
0\end{array}$ & $\begin{array}{l}0 \\
0 \\
0 \\
0 \\
1 \\
1 \\
0 \\
1 \\
3 \\
0 \\
0 \\
0 \\
0 \\
1 \\
0 \\
0 \\
2\end{array}$ & $\begin{array}{l}0 \\
2 \\
0 \\
0 \\
0 \\
0 \\
1 \\
1 \\
0 \\
0 \\
0 \\
0 \\
0 \\
0 \\
0 \\
1 \\
0\end{array}$ & $\begin{array}{l}0 \\
0 \\
0 \\
0 \\
1 \\
0 \\
1 \\
0 \\
0 \\
0 \\
1 \\
1 \\
0 \\
0 \\
0 \\
0 \\
0\end{array}$ & $\begin{array}{l}1 \\
9 \\
5 \\
1 \\
3 \\
3 \\
1 \\
5 \\
0 \\
1 \\
1 \\
0 \\
0 \\
0 \\
2 \\
2 \\
2\end{array}$ & $\begin{array}{c}\text { Hey: } \\
1.1-1000 \\
2.1001-2000 \\
3.2001-3000 \\
4.3001-4000 \\
5.4001-5144 \\
6.5145-5544 \\
7.5545-6047 \\
8.6048-6518 \\
9.6519-7262 \\
10.725-8145 \\
11.8145-9190 \\
12.9191-10000 \\
13 . \text { Beyond } \\
10,000\end{array}$ \\
\hline $\begin{array}{l}\text { Total } \\
\text { Per Cent }\end{array}$ & $\begin{array}{l}1371 \\
75.5\end{array}$ & $\begin{array}{l}167 \\
9.3\end{array}$ & $\begin{array}{r}82 \\
4.5\end{array}$ & $\begin{array}{r}55 \\
3.7\end{array}$ & $\begin{array}{r}21 \\
1.2\end{array}$ & .6 & $\begin{array}{l}10 \\
.5\end{array}$ & $\begin{array}{r}6 \\
.3\end{array}$ & $\begin{array}{l}17 \\
.9\end{array}$ & $\begin{array}{r}9 \\
.5\end{array}$ & $\begin{array}{r}5 \\
.2\end{array}$ & $\begin{array}{r}4 \\
.2\end{array}$ & $\begin{array}{r}36 \\
2.0\end{array}$ & 1789 \\
\hline
\end{tabular}




\section{TABLE XLIII}

VOCABULARY ANALYSIS OF REPRESENTATIVE SELECTIONS PROU FIVE SIXTH GRADE HISTORY BOOKS USED FOR HISTORY COMPREHENSION TESTS

(Thorndike's Clasalfigation. Frequency of Ueage)

\begin{tabular}{|c|c|c|c|c|c|c|c|c|c|}
\hline \multirow{2}{*}{$\begin{array}{l}\text { Frequency } \\
\text { of Ueage } \\
x-1000\end{array}$} & \multicolumn{9}{|c|}{ Selaction } \\
\hline & $\begin{array}{r}\text { Book I } \\
\text { Words Per Cent } \\
\end{array}$ & \multicolumn{2}{|c|}{$\begin{array}{l}\text { Book II } \\
\text { words Per Cent }\end{array}$} & \multicolumn{2}{|c|}{$\begin{array}{l}\text { Book III } \\
\text { pords Per Cont }\end{array}$} & \multicolumn{2}{|c|}{$\begin{array}{l}\text { Book IV } \\
\text { Words Por Cent }\end{array}$} & \multicolumn{2}{|c|}{$\begin{array}{l}\text { Book V } \\
\text { Words Per Cent } \\
\end{array}$} \\
\hline $\begin{array}{lr}1-1000 & 1075 \\
1001-2000 & 117 \\
2001-3000 & 57 \\
3001-4000 & 30 \\
4001-5144 & 12 \\
5145-5544 & 6 \\
5545-6047 & 9 \\
6048-6518 & 3 \\
6619-7262 & 10 \\
7263-8145 & 8 \\
8146-9190 & 3 \\
9191-10,000 & 3 \\
\text { Beyond } 10,000 & 23\end{array}$ & $\begin{array}{r}79.4 \\
8.6 \\
4.2 \\
2.2 \\
0.9 \\
0.5 \\
0.6 \\
0.2 \\
0.7 \\
0.6 \\
0.2 \\
0.2 \\
1.7\end{array}$ & $\begin{array}{r}1161 \\
137 \\
83 \\
36 \\
30 \\
10 \\
12 \\
3 \\
6 \\
11 \\
2 \\
2 \\
31\end{array}$ & $\begin{array}{r}76.0 \\
9.0 \\
5.5 \\
2.4 \\
2.0 \\
0.7 \\
0.8 \\
0.2 \\
0.4 \\
0.7 \\
0.1 \\
0.1 \\
2.1\end{array}$ & $\begin{array}{r}1293 \\
92 \\
38 \\
22 \\
8 \\
3 \\
6 \\
7 \\
8 \\
7 \\
2 \\
4 \\
22\end{array}$ & $\begin{array}{l}85.5 \\
6.7 \\
2.5 \\
1.4 \\
0.5 \\
0.1 \\
0.3 \\
0.4 \\
0.5 \\
0.4 \\
0.1 \\
0.2 \\
1.4\end{array}$ & $\begin{array}{r}1434 \\
152 \\
84 \\
27 \\
23 \\
11 \\
11 \\
10 \\
13 \\
12 \\
4 \\
2 \\
45\end{array}$ & $\begin{array}{l}78.7 \\
8.3 \\
4.6 \\
1.4 \\
1.2 \\
0.6 \\
0.6 \\
0.5 \\
0.8 \\
0.6 \\
0.2 \\
0.1 \\
2.4\end{array}$ & $\begin{array}{r}1371 \\
167 \\
82 \\
55 \\
21 \\
6 \\
10 \\
6 \\
17 \\
9 \\
3 \\
4 \\
36\end{array}$ & $\begin{array}{l}76.5 \\
9.3 \\
4.5 \\
3.7 \\
1.1 \\
0.3 \\
0.5 \\
0.3 \\
0.9 \\
0.5 \\
0.2 \\
0.2 \\
2.0\end{array}$ \\
\hline Total word: 1356 & $100 \%$ & 1529 & $100 \%$ & 1512 & $100 \%$ & 1821 & $100 \%$ & 1789 & $100 \%$ \\
\hline \multicolumn{2}{|c|}{$\begin{array}{l}\text { Number beyond } 6047-50 \\
\text { Per Cont beyond } 6047-3.6 \%\end{array}$} & \multicolumn{2}{|c|}{$\stackrel{55}{3.6 \%}$} & \multicolumn{2}{|c|}{$3.0 \%$} & \multicolumn{2}{|c|}{${ }_{4.6 \%}^{86}$} & \multicolumn{2}{|c|}{$\begin{array}{r}77 \\
4.18\end{array}$} \\
\hline
\end{tabular}

* Selection: Serenteen selections from eaoh of Books I, II, III, IV and $V$ were used for the Hi story Comprehensi on Tosts. 
Table XLIII, (page 131), is a sumary of the vocabulary analyses $f$ or the five books. Given in the vertioal colums are the totals for each categery, showing the number of words and the per cents for each. At the foot of this table, in the flrgt horizontal line, are shown the number and per cent of all words from each book which lle beyond the 10,000 rank.

Tabulating all of the words from the seventeen paragraphs as a representative sample of Book I, Table XLIII shows in vertical order that 79.4 per cent of the words are between 1 and 1000; 8.6 per cent between 1001 and 2000 , to. Table XLIII, read in horizontal order, also shows the per cent of words from each book lying in a glven rank, as: Book I has 79.4 per cent of its words in rank $1-1000$; Book II, 76.0; Book III, 85.5; Book IV, 78.7; and Book $\nabla$, 76.5 .

Book III shows the highest per cant of words in the first rank and Book II the lowest. When compared for words beyond 10,000 , Book II has a higher rank by .7 per cent. Book IV shows the highest per cent of words beyond 10,000 , wi th Book II next in order.

Words lying beyond 6047, however, are of greater significance, since they lie beyond the range of sixth-A pupils as interpreted by this study. (See Chapter III, p. 46). Book IV shows 4.5 per oent of 1 ts words to be beyond 6047. Book $V$ ranks next with 4.1 per cent of 1 ts 
worda beyond this range. Book III ranks 1 omest wth 3.0 per cent.

This study consldered answering with 97 per cent accuracy as essential to satisfactory comprehension of the reading samples given on the five history books. 4 The per cents given in Table XLIII are for the words above 6047. The writer wished to determine the per cent of words belon 6047. The per cent of words Iylng above 6047 was, therefore, subtracted from 100 per cont. Thus Book I has 3.6 per cent of its words lying above 6047 and 96.4 per cont of 1 ts worda lying below 6047 .

Analysis was made of the signifloance of the per cent of words falling beyond a frequency of 6047 for each of the tive looks. In dolng this the probable errors of the per conts were calculated by neans of the formula:

$$
\mathrm{P} \cdot \mathrm{B} \cdot \mathrm{B \%}=.6745 \sqrt{\frac{\mathrm{pq}}{\mathrm{H}}}
$$

where $P$ refers to the per cent in one category, $q$ to the per cent In the other category and $N$ to the number of cases.5 If a per cent is 3.00 or more tlma its probable error greater than zero it is considered signiticant; if less, not algniflcant. The a ata are given in Table XLIV, page 134.

It will be noted that all these per conts are signif1cantly greater than zoro. From purely statistioal point of view we may say then that none of the books examined

\footnotetext{
4. Author's arbitrary rocabulary standard, op. olt., Chapter III, p. 67.

5. Dunlap, J. W., and Kurtz, A., Handbook of Statisticai Namographs. Tables. and Formilag.1932,Formula No.48, 3.24
} 
restrict their rocabularies sufficlently for the tandards set dom in the literature (Chapter II) or in this study.

TABLI XLIV

DIFF ERENCES BETWEEN TIE FIVE HISTORY BOOKS FOR THE PER CENT OF WORDS BEYOND 6047

BOOK I BOOK II BOOK III BOOK IV BOOK $\mathbf{Y}$

Number of

Words Beyond 6047

50

55

so

B6

77

Per Cent of

Torda Bayond

6047

3.6

3.6

3.0

4.6

4.1

Probable

Error

of the Per

Cent of Fords

Beyond 6047.0004

.0032

.0030

.0033

.0033

$\frac{8}{P \cdot B}+\%$

10.6

11.3

10.0

13.9

12.4

Signiflcant

Yes

Yes

Yes

Yos

Yos

Rank

$2 \frac{1}{2}$

2]

1.

5

4 
Statistical anelyats of the differences between per cents reveals that Book IV has a signifloantly larger per oent of words beyond a frequency value of 6047 than $d 00$ Book III and that none of the other differences are signt. ploant. Therefore, while we might rank the books relative to restriction of vocabulary for sixth-A grade requirements we would be justifled only in saying that Book III meets these requirements more adequately than does Book IV. From Table XLIV it 111 be noted that none of them are satiafactory. The flindings of this analysis simply are that all the books are unsatisfactory in this respect and that Book IV is more unsati sfactory than is Book III.

Table XLV, page 136, Gives the calculations for this last analygis. A - B refers to sucossive differences botween per cents of words falling boyond a frequency value of 6047. "D" is the difforence. P.E. diff. Is the probable orror of the difference calculated by the accepted formula:

$$
P \cdot E_{A-B}=\sqrt{\frac{F_{B \cdot A}^{2}}{P \cdot E \cdot B^{2}}}
$$

were the measures are uncorrelated. 6

6. Dunlap, J. $\pi .$, and Kurtz, A. K., Llandbook of Statistical Nomographs, Tables and Formulas. 1932, Formila No. $157 \mathrm{~A}$, p. 16. 
3TATISTICAL ANALYSIB OF THE PER CENT OF WORDS BEYOND A FREQUENCY VALUE OF 6047 FOR FIVI SUPPLEMEN TARY HISTORY BOCKS

\begin{tabular}{ccccc}
\hline$A-B$ & $D$ & $P . \mathrm{E} . \mathrm{diff}$ & $\mathrm{D} / \mathrm{P} . \mathrm{E}_{\mathrm{d} \text { Iff. }}$ & Signifleant \\
\hline $.036-.036$ & 0.00 & .0047 & 0.00 & No \\
$.036-.030$ & .006 & .0045 & 1.33 & No \\
$.036-.046$ & .010 & .0048 & 2.08 & No \\
$.036-.041$ & .005 & .0048 & 1.04 & No \\
$.036-.030$ & .006 & .0044 & 1.31 & No \\
$.036-.046$ & .010 & .0046 & 2.16 & No \\
$.036-.041$ & .005 & .0046 & 1.04 & No \\
$.030-.046$ & .016 & .0045 & 3.56 & Yea \\
$.030-.041$ & .010 & .0045 & 2.44 & No \\
$.046-.041$ & .005 & .0047 & 1.06 & No \\
\hline
\end{tabular}

Table XLV gives the differences between the books for per cent of words beyond a frequency value of 6047 . It reveals that Book IV has a signiflcantly larger per cent of words beyond 6047 than does Book III and that none of the other differences are significant. 
B. Sentence and Phrage Analygis

Sentences were analyzed on four bases:

1. Mumber of sentences to the paragraph

2. Number of sentenoes to the book as represented by the total of the serenteen seloctions

3. Average number of words to the sentence, counting five letters to the word

4. Average number of words to the book as represented by the total of the seventeen selections

Fhrases were analyzed for the same four bases with an additional fifth, the number of phrases to the sentence. Table XIVI, (page 139), gives the sentence and phrase analyses of the selections from Book I. The table shows the:

1. Namber of words, (five letters to the word). to the parazraph and for the total selections

2. Number of phrages to the paragraph and for the total solootion:

3. Number of sentences to the paragraph and for the total seleotions

At the foot of Tabie XLVI is shown the moan and its probable error por:

1. Mear sentence-length

2. Mean phrase-length

3. Mean phrases to the sentence

Paragraph No. I in Table XLVI contains 72 words, counting five letters as one word. Paragraph No. 2 contalns 75 unit words; Faraisaph No. 3, 69, etc.

To obtain this unit word all of the letters in a paragraph were counted and the sum divided by five. 
There are 12 phrases in the first paragraph and 5 sentences. The phrase-length of this paragraph is, then, 6 words, and the sentence-length, 14.5 words.

The fourteenth paragraph cantains 121 words, 23 phrase and 9 sentences, hence 1 ts phrase-length is 6.2 words and its sentence-length 13.4. Thls means that Paragraph No. 14 is a longer paragraph than Paragraph No.1, but there is little difference in the length of the phrase or the sentence.

Paragraph No. 17 is again a long paragraph, its phrase-length of 6.7 words appearing moh like that of the other two paragraphs, but its sentenoe-length of 15.1 words possibly making a signiflcant difforence. This paragraph also has 5 words lying beyond the 6047 range.

The number of worda to the phrase and the number of words to the sentence $f$ or all of the paragraphs were computed as shown above. From these were calculated the means and their probable errors, as wil be further di scussed under Table LI, (page 146).

Tables XLVII, XLVIII, XLIX, and L gitre the number of words, number of phrases and number of sentences for Books II, III, IV and $V$.

The sentence-lengths of Bocks II and III appoar some what allke with means of 15.29 and 15.64 , but Book IV shows a santence-length of 19.71 . The significance of differences between these moans $1 \mathrm{a}$ disoussed in part $C$ of this chapter. 
TABLE XLVI

SEUTENCE AND PIRABE ANALYSIS OF SELECTIONS COMPRISINO TEST MATERIAL FROA BOOK I*

\begin{tabular}{|c|c|c|c|c|c|}
\hline $\begin{array}{l}\text { Paragraph } \\
\text { Number }\end{array}$ & $\begin{array}{l}\text { Number of } \\
\text { Tords to the } \\
\text { Paragraph }\end{array}$ & $\begin{array}{l}\text { Number of } \\
\text { Phrases to } \\
\text { Puragreph }\end{array}$ & the & $\begin{array}{l}\text { Number of } \\
\text { Sentenoes to } \\
\text { Peragraph }\end{array}$ & the \\
\hline $\begin{array}{r}1 \\
2 \\
3 \\
4 \\
5 \\
6 \\
7 \\
8 \\
9 \\
10 \\
11 \\
12 \\
13 \\
14 \\
15 \\
16 \\
17\end{array}$ & $\begin{array}{r}72 \\
75 \\
69 \\
68 \\
51 \\
89 \\
43 \\
75 \\
47 \\
87 \\
42 \\
72 \\
53 \\
121 \\
69 \\
77 \\
121\end{array}$ & $\begin{array}{r}12 \\
11 \\
11 \\
11 \\
8 \\
13 \\
9 \\
12 \\
7 \\
18 \\
8 \\
8 \\
7 \\
23 \\
12 \\
15 \\
18\end{array}$ & & $\begin{array}{l}5 \\
4 \\
4 \\
5 \\
4 \\
7 \\
4 \\
6 \\
4 \\
7 \\
3 \\
5 \\
4 \\
9 \\
5 \\
4 \\
8\end{array}$ & \\
\hline Total: & 1231 & 203 & & 88 & \\
\hline \multicolumn{6}{|c|}{$\begin{array}{l}\text { Hean sentence length: } \\
\text { (5 letters to the word) } \\
14.00 \pm 1.081\end{array}$} \\
\hline \multicolumn{6}{|c|}{$\begin{array}{l}\text { Mean phrase length: } \\
\text { (5 letters to the word) }\end{array}$} \\
\hline \multicolumn{6}{|c|}{ Hean phrases to the sentenoe: } \\
\hline
\end{tabular}

* Refers to Europe the Mother of America by Charles F. Horne and Olive Bucks. Now York, Charlo E. Merrill Company, 2930. 
TABLE XLVII

SENTENCE AND PHRASE ANALTSIS OF SELBCTIONS COMPRI $3 I N G$ TEST MATERIAL FROU BOOK II*

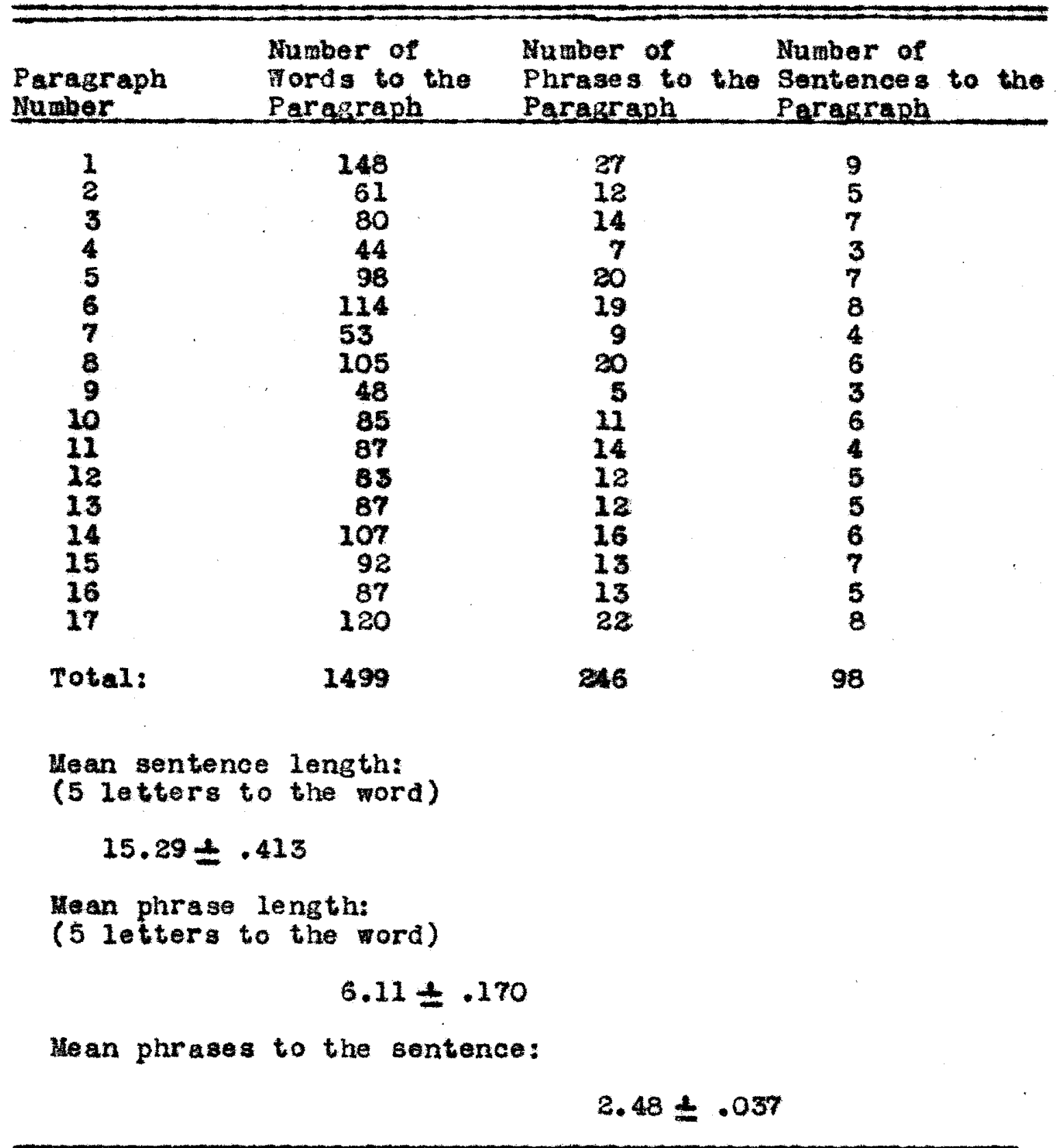

* Refers to Our Nation's Herltege by Reuben Post Halleak and Jullette Frante, Now York, Amertean Book Company, 1931. 
TABLE XIVIII

SENTENCE AND PHRASE ANALYSIS OF SELECTIONS COMPRISING TEST MATERIAL FROA BOOK III*

\begin{tabular}{cccc}
\hline \hline Paragraph & $\begin{array}{l}\text { Number of } \\
\text { Words to tho } \\
\text { Paragraph }\end{array}$ & $\begin{array}{l}\text { Number of } \\
\text { Phrases to the } \\
\text { Paragraph }\end{array}$ & $\begin{array}{c}\text { Number of } \\
\text { Sentenoes to the } \\
\text { Paragraph }\end{array}$ \\
\hline 1 & 61 & 11 & 5 \\
2 & 39 & 7 & 5 \\
3 & 89 & 15 & 4 \\
4 & 61 & 9 & 3 \\
5 & 67 & 12 & 4 \\
6 & 55 & 8 & 4 \\
7 & 66 & 12 & 5 \\
8 & 128 & 19 & 7 \\
9 & 94 & 14 & 6 \\
10 & 128 & 14 & 11 \\
11 & 78 & 7 & 5 \\
12 & 45 & 16 & 3 \\
13 & 78 & 15 & 4 \\
14 & 81 & 14 & 5 \\
15 & 75 & 13 & 5 \\
16 & 83 & 13 & 6 \\
17 & 82 & 219 & 7 \\
Total: & 1310 & & 89
\end{tabular}

Hean sentence length:

( 5 letters to the word)

$$
15.64 \pm .632
$$

Wean phrase length:

(5 letters to the word)

$$
5.89 \pm .042
$$

Mean phrases to the sentence:

$$
2.71 \pm .043
$$

* Refers to The old tor 1d Beginnings of Amerioa by Mary C. KeIty. New York, Ginn and Company, 1932. 
TABLE XLIX

3ENTENCE AND PIRASE ANALYSIS OF STLBCTIONS COMPRISING TEST WATERIAL FROM BOOK IV*

\begin{tabular}{llll}
\hline & Number of & Nurber of & Number of \\
Paragraph & Tords to the & Phrages to the Bentonoes to the \\
Number & Paragraph & Paragraph & Paragraph \\
\hline
\end{tabular}

$\begin{array}{rrrr}1 & 119 & 21 & 6 \\ 2 & 86 & 10 & 5 \\ 3 & 103 & 16 & 6 \\ 4 & 100 & 16 & 6 \\ 5 & 92 & 12 & 5 \\ 6 & 90 & 11 & 4 \\ 7 & 122 & 20 & 8 \\ 8 & 92 & 13 & 4 \\ 9 & 86 & 12 & 5 \\ 10 & 105 & 14 & 5 \\ 11 & 80 & 11 & 3 \\ 12 & 85 & 10 & 3 \\ 13 & 117 & 17 & 6 \\ 14 & 132 & 23 & 6 \\ 15 & 108 & 13 & 5 \\ 16 & 91 & 12 & 6 \\ 17 & 107 & 15 & 6 \\ & & & 89\end{array}$

Mean sentence length:

(5 lotters to the word)

$$
19.71 \pm .555
$$

Mean phrase length:

( 5 letters to the word)

$$
7.11 \pm .224
$$

Mean phrases to the sentence:

$$
3.23 \pm .034
$$

* Refers to The Amertoen People and Thedr Old World Anceptorg by Grace Volintine. NeT Tork, Ginn and Company, 1930 . 
TABLE L

SENTENCE AND PHRASE ANALYSIS OF BELECTIONS COMPRISING TEST MATERIAL FROA BOOK V*

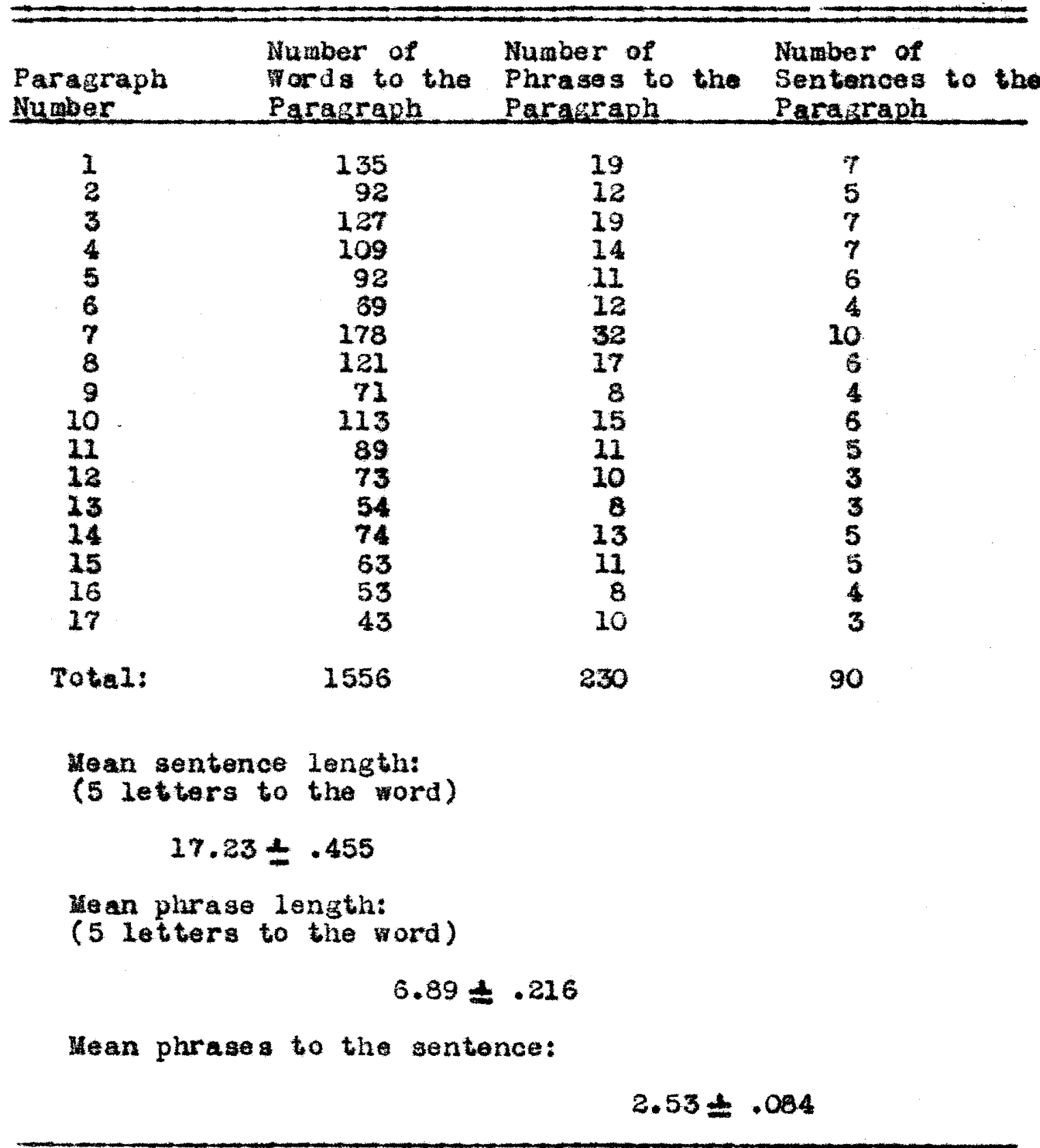

* Refers to The Elementary Vorle Hiatory by Charles A. Beard and Wiliham C. Bagley. New Tork, The Macmilien Corpany, 1932. 
Table LI, (page 146), gives the statistical analyalo of the data in Tables XLVI and XLVII, (pages 139-140) for Books I and II.

Analysis is given for:

1. Bentence-length in words

2. Phrase-length in words

3. Number of phrases to the sentence

For each of the above Table LI gives the:

1. Wean

2. Stendard deviation of the distribution

3. Probable error of the distribution

4. Probable error of the mean

5. Standard error of the man

6. Standard error of the standard deriation

The means wore lirat calculated for the sentencelength of each book from the guessed average by the formis:

$$
H=G \cdot A \cdot \pm 0^{7}
$$

The standard deviations were then computed by the formala:

$$
\sigma=\sqrt{\frac{E\left(x^{2}\right)^{2}}{N}-\frac{(E x)^{2}}{(N)}}
$$

8

The probable errors of the distribution were taken from Dunlap's and Kurtz" table: "Converting Standard Errors to Probabla Errors." 9

7. Earret, Henry E., Statisticg in Paychology and Education. $1932, \mathrm{p} .29$.

8. Dunlap. J. T., and Kurtz, A. K., Handbook of Statigtical Nomographs, Tables and Formias. 1932, Formula No. 37-A, p. 14.

9. Ibld., Table 90, p. 90 . 
The probable error of the mean was caleulated from the format

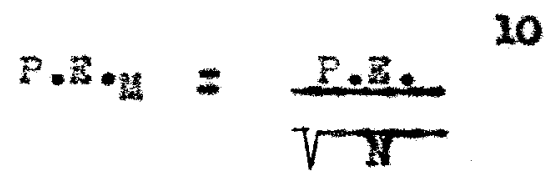

the standard deviation of the mean. from the formulat

$$
\sigma_{u}=\frac{\sigma}{\sqrt{T}}^{11}
$$

the stindard errors of the standard deviations were onleulated fros the format

$$
\sigma_{\sigma}=\frac{\sigma}{\sqrt{2}}^{12}
$$

The same procedures were uaed to analyze the phraselength and the number of plrases to the sentenae. Table LII. (page 147), ahows the analygis of the data in Fablas YLVIII and XLIX for Book III and Book IV. Table LIII. (page 148), shows the analyals of data In Table $L$ for Book $V$.

10. Dunlap, I. T., and Kurtz, A. K., Hengbook of gtathetioad Logojrapha. Tabios and Formulag. 1932, Formala Ho. 5 B. p. 6.

11. Fbld., Formula No. 5, p. 4 .

12. Ibfo.: Tormila No. 41, p. 16. 
TABLE LI

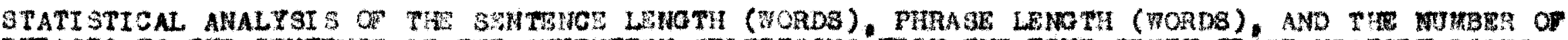

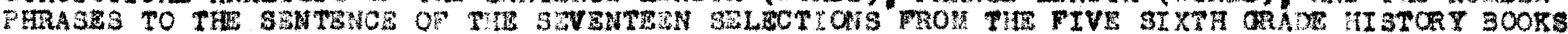

BOOK I I

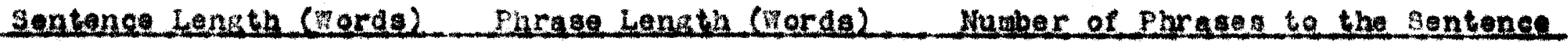

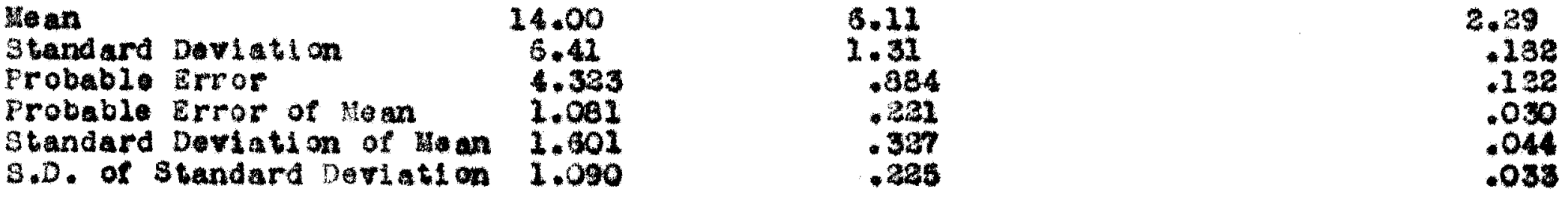

BOOK IT*

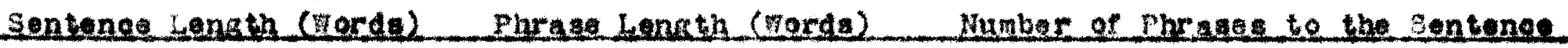

\begin{tabular}{|c|c|c|c|c|}
\hline $\begin{array}{l}\text { Mean } \\
\text { Standard } \\
\text { Probable } \\
\text { Probablo } \\
\text { 3tandard } \\
\text { S.D. of }\end{array}$ & $\begin{array}{l}\text { Deviation } \\
\text { Error } \\
\text { Error of Hean } \\
\text { Deviation of Wean } \\
\text { Standard Deviation }\end{array}$ & $\begin{array}{r}15.29 \\
2.48 \\
1.532 \\
.413 \\
.512 \\
.433\end{array}$ & $\begin{array}{r}.11 \\
1.019 \\
.681 \\
.170 \\
.852 \\
1.75\end{array}$ & $\begin{array}{l}2.48 \\
.282 \\
.149 \\
.037 \\
.054 \\
.041\end{array}$ \\
\hline
\end{tabular}

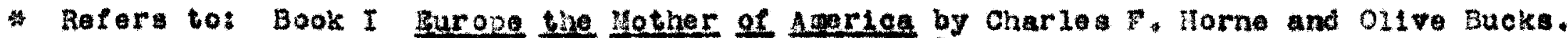
Wer York charles $\mathrm{E}$. Mertil Company. 1930.

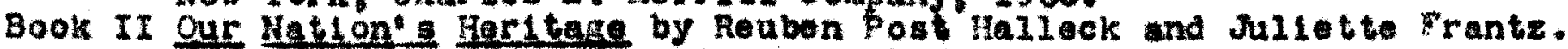
Now York. Aiterían Book Company. 1931. 
TABLE LII

STATISTICAL ANALXSIS OF THE SENTENCE LENGTH (WORDS), PHRASE LENGTH (MORDS), AND THE NUNBER OF PHRASES TO THE SENTZNCE OF THE SEVENTEEN SELECTIONS FROU THE FIVE SIXTH GRADE HISTORY BOOKS

BOOR III*

Sentence Length (nords) Phrage Length (Fords) Number of Phrsas to the Sentence

Hean

Standard Deriation

Probable Error

Probabie Error of Mean

Standard Deviation of Mean

$\begin{array}{rr}15.64 & 5.89 \\ 3.75 & .261 \\ 2.529 & .177 \\ .632 & .042 \\ .937 & .062 \\ .643 & .447\end{array}$

2.71

.257

.175

.043

.063

S.D. of Standard Deviation

.937

.044

BOOK IV*

Sentence Length (words) Phrase Length (Words) Number of Phrages to the sentena

$\begin{array}{lrr}\text { Hean } & 19.71 & 7.11 \\ \text { Standard Deviation } & 3.29 & 1.33 \\ \text { Probable Errof } & 2.219 & .897 \\ \text { Probable Error of Hean } & .555 & .224 \\ \text { Stendard Deviation of me an } & .822 & .332 \\ \text { S.D. of Standard Deviation } & .547 & .228\end{array}$

3.23

.204

.137

.034

.050 .035

* Refers to: Book III The old Vorld Beginninge of Amarlas by Mary C. Kelty. New York, Ginn and Company, 1932 .

Book IV The American People and Their $01 d$ world Ancestora by orace VoIlingine. Tev York, GInn and Company, 1930. 
TABLE LIII

STATISTICAL ANALYSIS OF THE 3ENTENCE LENGTH (WORDS), PHRASE LENGTH (WORDS), AND TIIE NUBBER OR PHRASES TO THE SENTENCE OF THE SEVENTEEN SELECTIONS FROA THE FIVE SIXTH GRADE IIISTORY BOOKS

BOOK V*

Sentence Length (Words) Phrase Length (words) Number of Phrases to the Sentence

Me an

Standard Deviation

Probablo Error

Probable Error of thean

Standard Deviation of Hean

S.D. of Standard Deviation

$\begin{array}{rc}17.23 & 6.89 \\ 2.71 & 1.18 \\ 1.820 & .863 \\ .455 & .218 \\ .674 & .320 \\ .464 & .202\end{array}$

2.53

.50

.337

.084

.224

.085

* Refers to: Book V The Elementary World History by Charles A. Beard and Wiliam C. Bagley. New York, The UacmiIlan Company, 1932. 
c. Cogarerison of the rive Booka cor Sencance-zangtil

Table LV, (page 15E), corparea the five booke for antence-longth. The data for these compartiona have been given proviousiy in tasle XLVI to LIIY. Theos data aro brought together in Tabla LV.

In this table $\mathrm{x}_{1} \mathrm{H}_{2}$ is the difference between the wean sentence-length of Book $I$ and Book $I I_{1} M_{1} H_{3}$ is the difference between Book I and Book III, atc. The difference betwean $\mathrm{x}_{1}{ }^{-4} \mathrm{H}_{2}$ il 1.29 ; the difference between 15.99 and 14.00. (Table LI)

F. Ediff. is the probable error of the diffarence between means, In this case, ${ }_{2}-\mathrm{K}_{2}$. It was calculated from the formata:

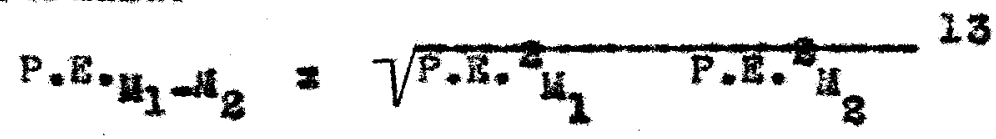

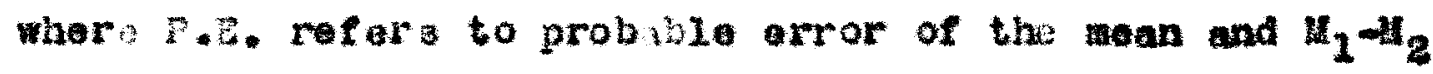
to successive mana.

Diff. $f$. divided by ite probable error. In thits case: $2.29 / 1.15=1.12$. It a difference divided by 1 is probable arror is 3.0 or more, 1. 5 conatdered stenificant. These are indicated by "Yea" or "No. 14

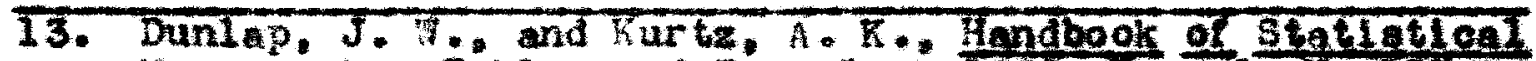
Nongtraphe. Tables and Foraulas: 1532, Formina Ho.15t.

14. Link, H. G. "Ilow Jany Interviewa Are Noosasary for Re sults of a Certain Accuraoy, "Journal of Apolied Esychology. Volume 21, $1937, \mathrm{p} .5$. 
Compared on their sentence-length, then, there is a gignificant difference between Book I and Book IV, Book III and Book IV, and Book $V$ and Book IV.

The wost algnificant difference betwoen books is be tween Book II and Book IV, whil le the least significant difference is between Book II and Book III, thus Indicating that Books II and IV are different to a marked degree and Books II and III are much alfke.

When ranked as to mean sentence-length the books show the followlng order:

\section{TABLE LIV}

$$
\text { BOOLS RANKED AS TO SENTEHCB-LENGTH (TORDS) }
$$

(No. 5, greatest mean length; No. 1, least wean length)

\begin{tabular}{lll}
\hline Books & Author & Ragk \\
\hline IV & Vollintine & 5 \\
V & Beard and Bagley & 4 \\
III & Kelty & 3 \\
II & Halleck and Frantz & 2 \\
I & Horne and Buoks & 1 \\
\hline
\end{tabular}

When the books were compared for any diffarences in their standard deviations, a significant difference appeared between Books $I$ and II, Books $I$ and III, Books $I$ and $I V$, and Books I and $V$. 
KEX TO TEE POLLOWIHG TABLES LV, LVII, LIX, LXII, LXY

$\mathbf{u}_{\mathrm{A}}-\mathbf{u}_{\mathrm{B}}$

Diff .

F. E.duet $\cdot W^{\prime}$

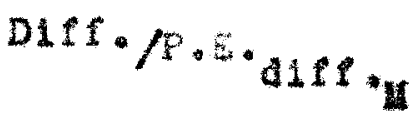

$\sigma_{\bar{A}}-\sigma_{\bar{B}}$

Dif?.

$p \cdot 2 \cdot a+f \cdot a$

Deftep.e.dete.

31 gniflongt?
Coaparison between the varlous Reans for the soventeon

selsetlons fron Book I and Book II, ote., suoh as sentence Length, Mumber of Phrases and 5 tords to Fhrase.

Differance botwoen Meana

Probablo Error of difference betweon theans

Differance between Mans alvided by thelr Frobable Frors

Differences betreen the standard Deviations of the seventesn qe leotione from Book I. Book II, ece.

Diffarance botwean standard Daviations

Probable inror of differenoe between standard Devlatione

Difference betwen Standard Deviations divided by thes Probable Brrors.

If a difference divided by $16 \mathrm{~s}$ probable error 133.0 or more, 14 is coneldered signifloant, if loss. It is conside red not ignificant. These are Indieated by "Tos" or no." (Link. H.C." "How Sany Intervieva A ro Nocessary for Sasult of a dertain Aoouraoy." Journal of Applied Esyoholosy, volume 21. $1337, p$. 5 . 
TABLF LV

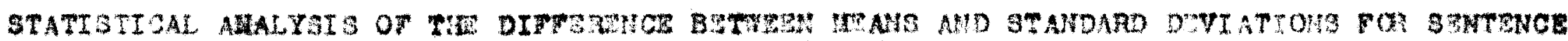

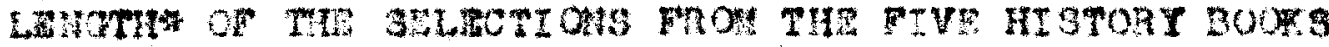

COMFAR SON OF NGRAGRS GOYPARISOU OF STAPDARD DUVATCONS

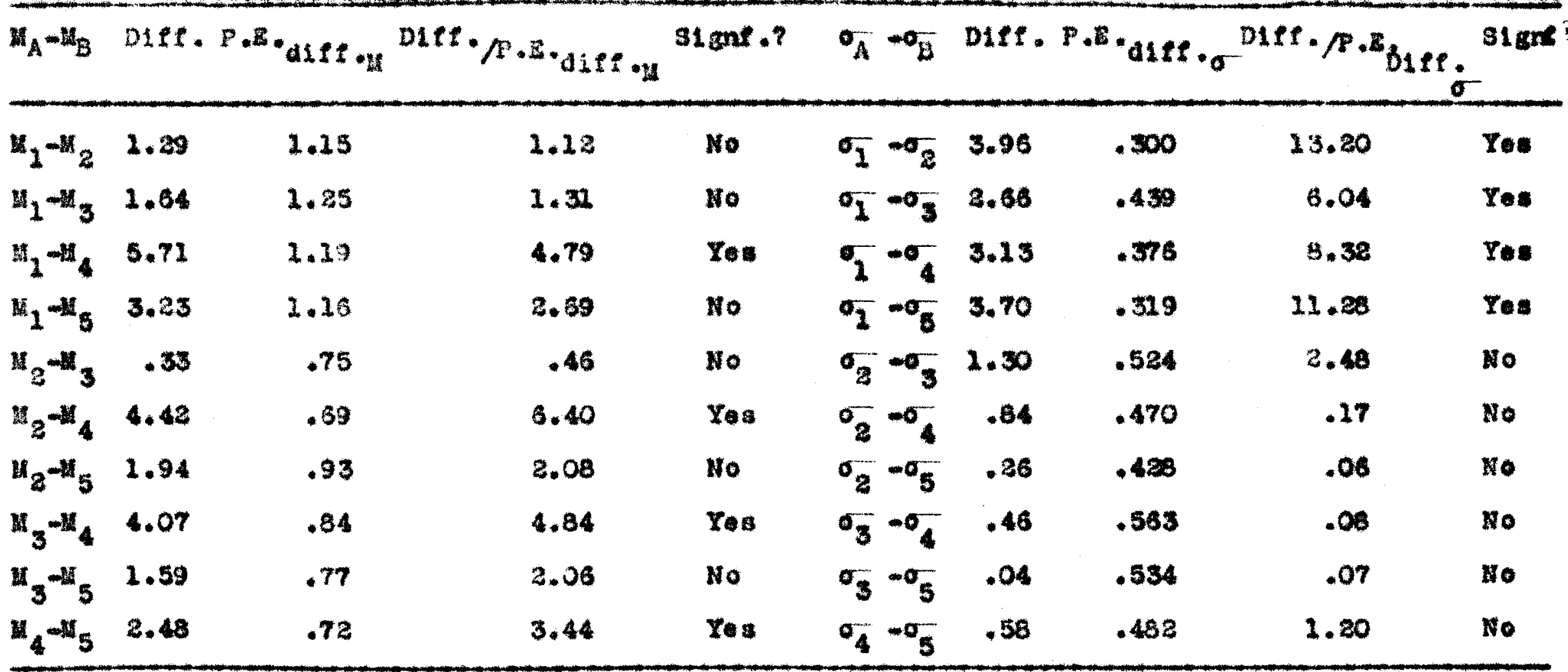

* Sentence Length - the nutaber of words to a sentenoe counting five letters to the vord. 
F. Comparigon of the Fire Booke for nubber of Sentencen to the Pararraph

The books vere compared for the muber of wentences to the paragraph by the ane process as used for sentonoelength.

Table LVI gives the following data for each of the five books:

1. Hean

2. Standard derlation

3. Probable error

4. Probable error of man

5. Standard orror of the atandard deviation

As the weans appoar in Table LVI they aeen mueh allke wi th Book II ghowing the large at number of sontenees to the paragraph and Book III the sallest number.

\section{TABLE LVI}

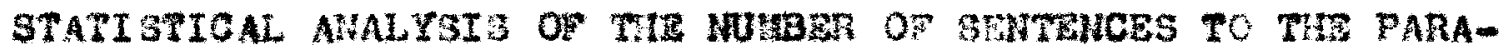

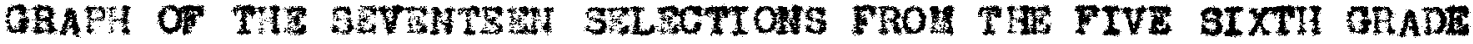
IIsTort Books

Bentences

Per Paragraph Book I Book II Book III Book IV Book $Y$

Lean

5.23

5.77

5.11

5.23

5.29

Standard

Deviation

1.551 .56

2.56

1.32

2.77

Probable Error

1.045

1.120

1.720

.826

2.194

Probable arror

of Hean

.261 .280

$$
.430
$$

.204

.298

Standard Error

of stendard

Deviation

$.265 \quad .284$


TABLE LVII

STATISTCAL ANALYSS OF THE DIPFERENCE BETWEEN LAEANS AND STANDARD DEVIATIONS FOR THE NUHELR

OF BMNTENCES TO THE PARAORAPH OF THE SEVBNTEEN SELECTIONS FROE THE FIVE HISTORY BOOKS

\section{COMPARISON OF AVERAOES}

\begin{tabular}{|c|c|c|c|c|c|c|c|c|c|c|}
\hline $\mathrm{H}_{\mathrm{A}}^{-\mathrm{X}_{\mathrm{B}}}$ & Dife. P. B. & deff & Diff $\cdot R \cdot P$ dif & signe.? & $\sigma_{A}$ & $-\sigma_{B}$ & Defe. & P.E.dift: & 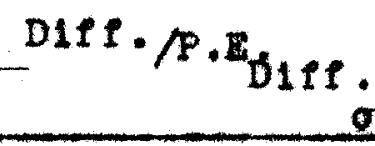 & $91 \mathrm{gx}$ ? \\
\hline & .54 & .772 & .69 & Ho & $\sigma_{1}$ & $-\sigma_{2}$ & .021 & .596 & .03 & No \\
\hline & .12 & .938 & .14 & No & $\sigma_{1}$ & -0 & .173 & .344 & .50 & No \\
\hline 1 & 0.0 & .748 & .0 & $N 0$ & $\sigma_{1}$ & & .058 & .225 & .25 & No \\
\hline & .06 & .772 & .07 & No & $\sigma_{2}$ & - & .038 & .273 & .13 & No \\
\hline & .66 & .513 & 1.28 & No & $\sigma_{2}$ & & .143 & .350 & .40 & No \\
\hline & .54 & .346 & 1.56 & No & $\sigma_{2}$ & $-\infty$ & .077 & .836 & .32 & No \\
\hline $\mathbf{u}_{\mathscr{q}}$ & .48 & .407 & 1.17 & No & $\sigma_{2}$ & -0 & .019 & .279 & .06 & No \\
\hline & .18 & .475 & .25 & No & $\sigma_{3}$ & - & .230 & .246 & .93 & 110 \\
\hline$u_{3}-u_{5}$ & .18 & .522 & .34 & No & $\sigma_{3}$ & $-\sigma_{5}$ & .066 & .357 & .18 & no \\
\hline $\mathbf{M}_{4}-\mathbf{M}_{5}$ & .06 & .360 & .16 & No & $\sigma_{4}$ & $-\sigma_{5}$ & .096 & .246 & .39 & No \\
\hline
\end{tabular}

\section{COAPARI SON OF STANDARD DEVI ATIONS}


To determine whe ther the differenoes are signifioant, the data from Table LVI is compiled in Table LVII, (pago 154), where each of the five books is compared with aach of the other books or any difference between means and standard deviations.

There are no significant differences between any of the books when compared for the number of sentences to the paragraph. Books I and IV are most allke, whlle Books II and IV show the highest ratio of difference.

When ranked for sentences to the paragraph, the books appear in the following order:

\section{TABLE LVIII}

BOOKS RAKKED AS TO NUMBER OF SENTENCES TO THE PARAGRAPH

\begin{tabular}{lll}
\hline & Author & Rank \\
\hline II & Halleok and Frantz & 5 \\
IV & Beard and Bagley & 4 \\
IV & Volilntine & $8 \frac{2}{2}$ \\
III & Horno and Buoks & $2 \frac{1}{2}$ \\
& Kelty & 1 \\
\hline
\end{tabular}

D. Comparison of the Fire Books for Phrase-Length

The flrst column of Tables XLVI to L, (pazes 139 to 143), gives the tabulation of the number of words, (PIve letters to the word), for each paragraph from the five history books.

The second colum gives the number of phrases to the paragraph. Thus the first paragraph of Book $V$, (page 143), has 135 words and 19 phrases. The average phrase-length, then, of Paragraph No. 2 is (135 19 ) 7.1 words. 
TABLE LIX

STATISPICAL ANALTSIS OF THE DIFTBRENCE BETWIEN UEANS AND STANDARD DEVIATIONS FOR THE NUMBER OF WORDS TO THE PHRASE OF THE SELWCTIONS FROH THE FIVE HISTORY BOOKS

COUPARISON OF AVEZAOES

COUPARISON OF STAIDARD DEVIATIONS

\begin{tabular}{|c|c|c|c|c|c|c|c|c|c|}
\hline$u_{A}-u_{B}$ & Diff. P.E. & atfo & DLff $/ P \cdot B \cdot$ diff & Signf +? & $\sigma_{A}-\sigma_{B}$ & Dife. & B. $\mathrm{al}$ & $\sigma^{D 1 f f} \cdot / P \cdot E_{\text {DIff }}$ & S1 gnt? \\
\hline$u_{1}-u_{2}$ & 0.0 & .27 & .0 & No & $\sigma_{1}-\sigma_{2}$ & .31 & .192 & 1.61 & No \\
\hline$u_{1}-u_{3}$ & .22 & .23 & .95 & No & $\sigma_{1}-\sigma_{3}$ & 2.05 & .357 & 3.11 & Yes \\
\hline$u_{1}-u_{4}$ & 1.00 & .31 & 3.21 & $Y_{\text {Q }}$ & $\sigma_{1}-\sigma_{4}$ & .02 & .150 & .13 & No \\
\hline$u_{1}-u_{5}$ & .78 & .31 & 2.51 & No & $\sigma_{1}-\sigma_{5}$ & .13 & .203 & .64 & No \\
\hline$u_{2}-H_{3}$ & .22 & .18 & 1.22 & No & $\sigma_{2}-\sigma_{3}$ & .75 & .323 & 2.32 & No \\
\hline$u_{2}-m_{4}$ & 1.00 & .28 & 3.57 & Yea & $\sigma_{2}-\sigma_{4}$ & .32 & .168 & 1.90 & No \\
\hline$M_{2}-M_{5}$ & .78 & .27 & 2.14 & No & $\sigma_{2}-\sigma_{5}$ & .17 & .201 & .84 & No \\
\hline$u_{3}-m_{4}$ & 1.22 & .26 & 4.69 & Yes & $\sigma_{3}-\sigma_{4}$ & 1.07 & . 337 & 3.11 & Yes \\
\hline$u_{3}-u_{5}$ & 1.00 & .22 & 4.54 & Yes & $\sigma_{3}-\sigma_{5}$ & .92 & .330 & 2.78 & No \\
\hline$u_{4}-M_{5}$ & .22 & .31 & .70 & No & $\sigma_{4}-\sigma_{5}$ & .15 & .205 & .74 & No \\
\hline
\end{tabular}


Under the second caption at the foot of the tables, (XIVI to L), are given the mean phrase-lengths and their probable errors for the live books.

Tables LI to LIII, (page 146-148) give the statistical analysis for the:

1. Mean

2. Standard deviation of the distribution

3. Probable error of the distribution

4. Probable error of the mean

5. Standard exror of the mean

6. Standard error of the standard deviation

These data are brought together in Table LIX, (page 156), for comparison of the means and standard devtations of the five books.

Table LIX shows that aignificant differences are found between Book I and Book IV, Book II and Book IV, Book III and Book IV, and Book III and Book V.

Book IV, th mean phrase-length of 7.11 words, appears as most unlike the other books. Book I and Book II appear to be much allke, as do Books I and III. The difference between Book II and Book III, though not signifloant, is 1.22 and somewhat larger than the other differences of 0.0 and .95 , which means that the phraselength of Book III is slightly more like that of Book I than that of Book II. 
The phrase-length of Book $V$ is more like that of Book IV than 1t is like any of the other books, differing mogt from Book III.

This 18 just the reverse of what was found when the books were compared for sentenee-length. Book V is more $11 \mathrm{ke}$ Book III on sentence-1ength than it is $12 \mathrm{ke}$ Book IV. (Table LV, p. 152).

When compared for variabi11ty, the phrase-length of Book V is lightiy nearer to Book IV than Book III, though net ther of the difference is algificant. There is a signifloant difference, however, between Books I and III, and Books III and IV for phrase-length.

Then ranked for phrase-length the books appear in the ellowing order:

TABLL LX

BOOKS RANKED AS TO PHRASE-LENGTH (YORDS)

\begin{tabular}{|c|c|c|}
\hline Book & Author & Renk \\
\hline $\begin{array}{r}I V \\
I I I \\
I I\end{array}$ & $\begin{array}{l}\text { Vollintine } \\
\text { Beard and Bagley } \\
\text { Horne and Bucks } \\
\text { Halleok and Frantz } \\
\text { Kelty }\end{array}$ & $\begin{array}{l}5 \\
4 \\
2 \\
2 \frac{1}{2} \\
1\end{array}$ \\
\hline
\end{tabular}

B. Comperison of the Five Books for the Number of phrases to the Paragraph

The number of phrases counted $f$ or each paragraph $f$ or the five books is tabulated in Tables XIVI to $L$, (pages 139 to 143). The statistical analyal s is given in Table LXI, (page 159). 
These data are brought together in Table LXII, (page 160), where comparison is made for the means and standard deviations of the IIve books for any signiflicant difference in the number of phrase to the paragraph.

\section{TABLE LXI}

STATISTICAL ANALYSI 3 OF THE NUHBER OF PHRASES TO THE PARAGRAPH OF THE SEVENTERN SELECTIONS FROM THE FIVE SIXTH GRADE HISTORY BOOKS

Phrases 60

Paragraph Book I Book II Book III Book IV Book V

Hean

11.95

14.76

12.89

14.48

13.89

Standard

Deviation

$\begin{array}{lllll}4.27 & 5.41 & 3.62 & 3.79 & 5.72\end{array}$

Probable Error

2.880

3.642

2.442

2.556

3.865

Probable Error of Hean

$$
.720
$$$$
.910
$$$$
.610
$$$$
.639
$$$$
.966
$$

Stand ard Error of Standard

Deviation

$\begin{array}{lll}.735 & .927 & .620\end{array}$




\section{TABLE LXII}

STATISTICAL ANALYOI 3 OF THZ DIFTSRENCE BETVEZN MEANS AND STANDARD DEVIATIOHS FOR THE NUMBER OF PHRASES TO THE PARAGRAPH OF THE SEVENTEEN SELECTIONS FROU THE FIVE HISTORY BOOKS

COMPARI SON OF AVERAGES COMPARI SON OF STANDARD DEVIATI ONS

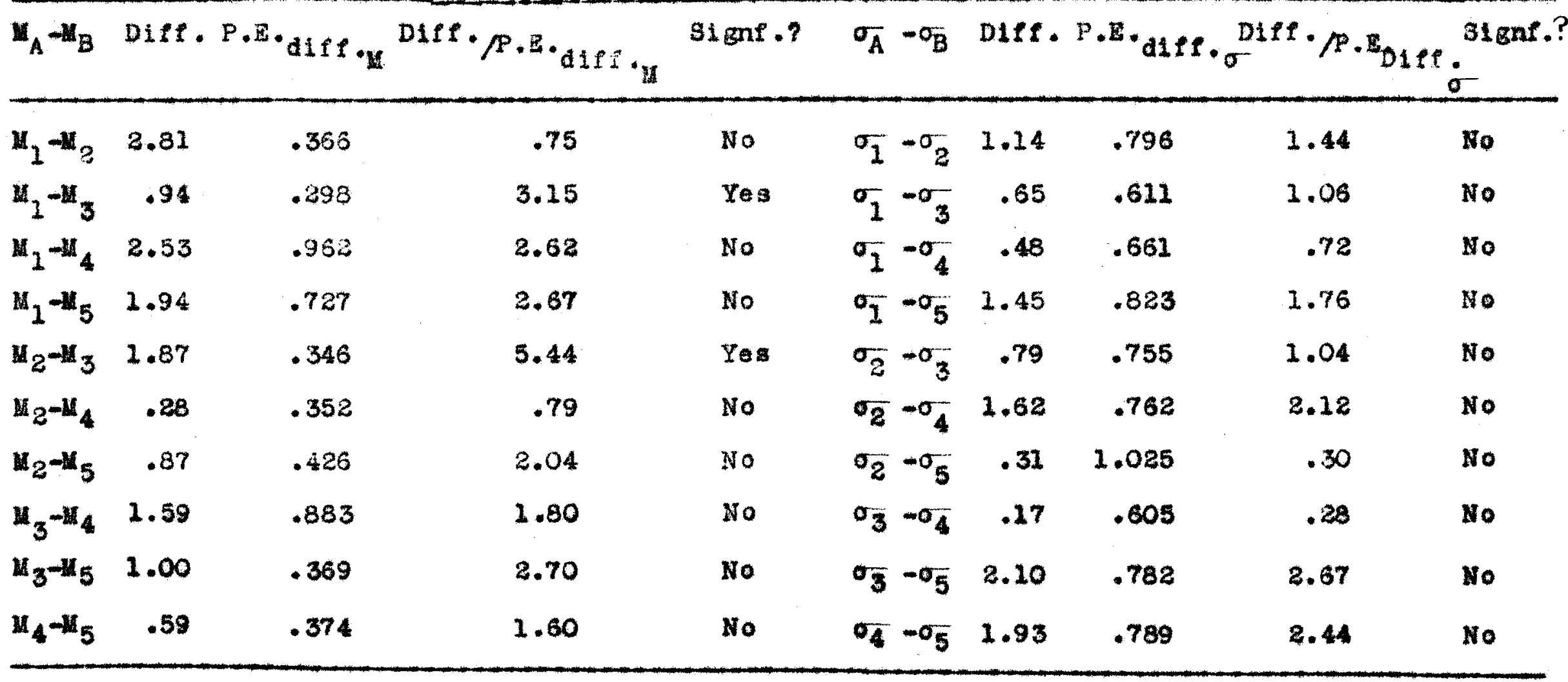


If a difference divided by its probable error is 3.00 or mora, it is considered sigrifieast; if less, it is considered not signifieant.15 If this difference was significant, it was marked "Yes;" if not signifleant, "Wo."

Observation of Table LXII shows a difference of 2.81 between $M_{1}$ and $M_{2}$, which, divided by its probable error gives .76, which is not significant. There is a difference of 1.87 between $H_{2}$ and $u_{3}$, critlal ratio, 5.44, which 1 s of course significant.

Signiflcant differences were found between Books I and III, and II and III.

There are no slgnitleant differences between the standard deriations on the number of phrases to the paragraph.

In number of phrases to the paragraph, the five books rank a follows:

\section{TABLE LXIII}

BOOKS RANKED FOR NUMBER OF PHRASES TO THE PARAGRAPH

Book Author Bank

\begin{aligned} & II Halleck and Frantz \\ & IV Volintine \\ & III Beard and Bagley \\ & I Kolty \\ & \hline\end{aligned}

Book I shows the greatest difference when compared with the other four books for the number of phrases to the paragraph. Book V ohows the least difference. Signifloant, differences are found between the mans of Books I and 
III, and Books II and III. No signifloant differences are found between the standard deviations of any of the books.

G. Comparison of the Five Boake for the Number of phrases to the Bentence

Tables XLVI to L, (pages 139-43), show the tabalation of the number of sentences and the number of phrases for each of the serenteen selections from the five books. Table XIVI, (page 139), show the tabulations Prom Book I.

Paragraph No. 1 containg 12 phrases and 5 sentences. There are, then, an average of $2.5(12 \div 5)$ phrases to the sentence.

Paragraph No. 2 contalns 11 phrases and 4 sentences, with an averaze of $2.7(11 \div 4)$ phrases to the sentence. The same may be found $f$ or all sentenese in the serenteen paragraphs.

The mean number of phrases to the sentence and their probable errors are given for each of the books at the $f$ oot of the table. Book I, for examle, has a mean of 2.29 phrases to the sentence, with probable error of $\neq .030$. The statistical analysis for the number of phrases to the sentence is given in Tables LI to LIII, (pages 146-148). The comparison of the five books for significant differenoes between means and standard deviations is given in Table LXIV, (page 163).

Here some of the differences between means show a very marked algniflcance. Book II and Book IV show the greatest difference of 15.00 . 


\section{TABLE LXIV}

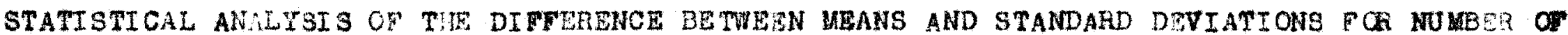
PHRASES TO THE 3ENTWNCE OF IHE SELECTIONS FROM THE PTVE HISTORY BOOKS

COMPARISON OF AVERACSS COIPART SON OF STANDARD DSVIATIONS

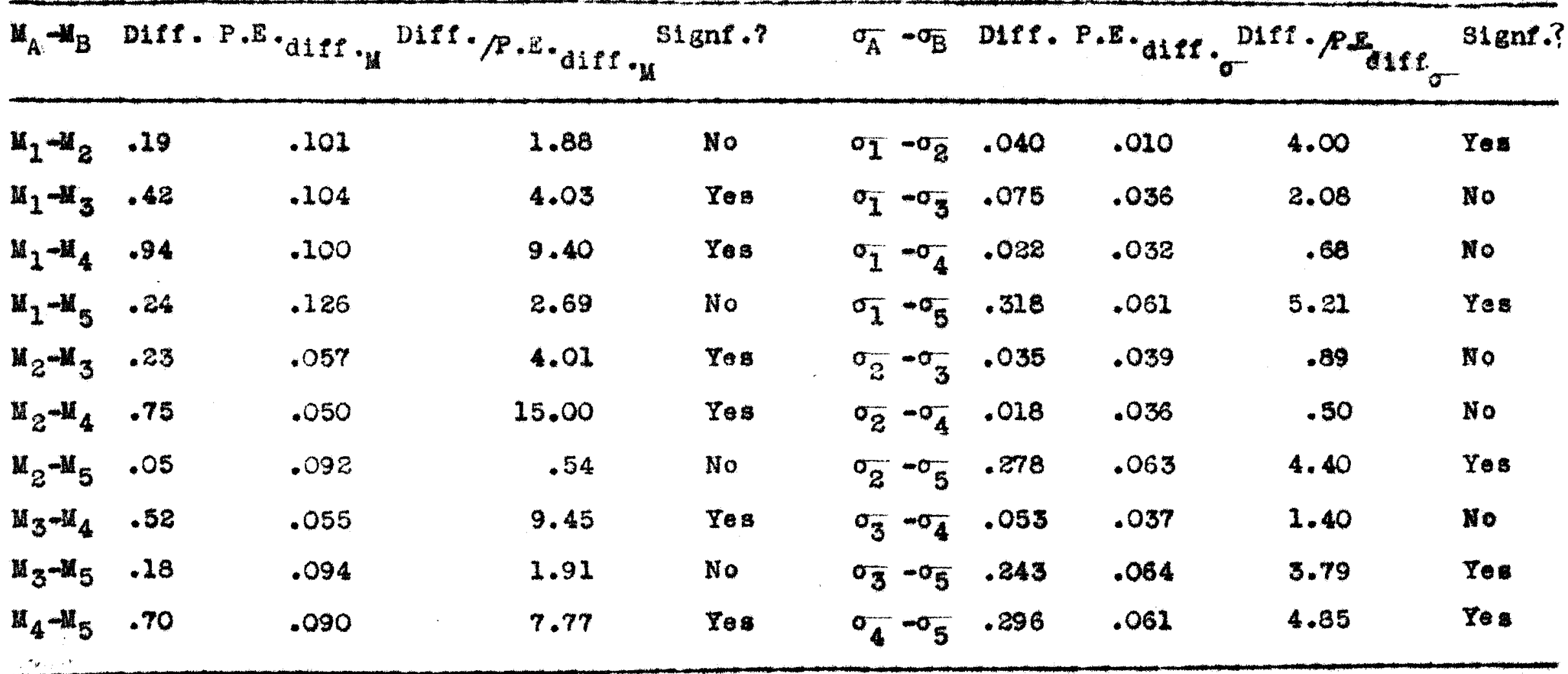


Signiflcant differences are shown between Books IV and I, IV and II, IV and III, IV and V, III and I, and III and II. Books I and II appear alike, as do Books II and $v$.

In the comparison of the five books for the number of phrases to the sentence, Books $\nabla$ and IV ars $f$ ound to be quite different, but the difference between Book III and Book $V$ is not signiflcant. Book $V$ is, then, more llke Book III in number of plrases to the sentence than it is $11 \mathrm{k}$ Book IV.

Differences are signifleant between the standard deviations for Books I and II, Books I and V, Books II and $V$, Books III and $V$, and Books IV and $V$.

Ranked as to the average number of phrases to the sentence, the books appear as follows:

TABLE LXV

BOOKS RANKED FOR TIE AVEIBAGR NUIBER OF PIIRA3ES TO THE SENTENCE

\begin{tabular}{clc}
\hline & & \\
\hline Book & Author & Ranks \\
\hline IV & Vollintine & 5 \\
III & Kelty & 4 \\
IV & Beard and Bagley & 3 \\
II & Halle ok and Frantz & 2 \\
I & Horne and Bucks & 1 \\
\hline
\end{tabular}

A summary of the six rankings of the five history books is given in Table LXVI, (page 165). In order to have one composite measure on which to judge the rank order of the difference between the boeks, the six ratings were averaged for each book. These averages appear at the foot of Table LXVI. 
TABLE LXVI

BOOKS RANK AD AS TO VOCABULART, SENTENCE-LEHOTH, (TORDS), PHRASE-LENGTH, (HORDS), PHRASES TO THE SENTENCE, NOUBER OF SENTTNCES TO PARAGRAPH, AND NUMBER OF PHRASES TO PARAGRAPH

Book I Book II Book III Book IV Book V

Voeabulary

2

4

1

5

3

Sentence Length

in Fords

1

2

3

5

4

Fhrase Length

in Words

23

2줄

1

5

4

Phrases to

Sentence

1

2

4

5

3

Sentences to

Paragraph

2 竞

5

1

2좀

4

Phrasea to

Paragraph

1

5

2

4

3

Average Rank

1.66

3.41

2.00

4.25

3.50

Using the average rankings of the books as a soale, they appear in the following order:

TABLE LXVII

BOOKS RANK AS TO THE AVERAGE RATINGS ON VOCABULARY, SENTENCELENGTH, (WORDS), PHRASE-LENGTH, (WORDS), PIRASPS TO THE SIHTENCE SENTRMCES TO THE PARAGRAPH, AND NULBER OF PHRASES TO THE PARAGRAPH

\begin{tabular}{clc}
\hline \hline Book & Author & Bonk \\
\hline IV & Vollintine & 5 \\
$V$ & Beard and Bagley & 4 \\
II & Haileck and Frantz & 3 \\
III & Kelty & 2 \\
II & Horne and Buoks & 1 \\
\hline
\end{tabular}




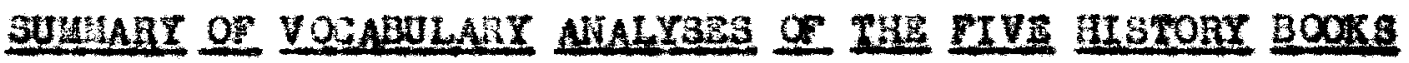

The I I buoks were analyzed and judged by oriteria of:

1. Voeabulary lying within the 6947

2. Sentenoemlength in morda

3. Number of sentances to the paragraph

4. Plrase-length in words

5. Nubber of phrasea to the paragraph

6. Wusber of phrases to the sentence

Bach of the five books was compared wh each of the other tour books by the above orltarla for any 11 keness or difference that existod botween then.

1. For vocabulary range per cents were used for comparing the books. For all othar masures, atatlstlcal analysla was uaed to detoraine the differenoe or likeness between books by oomparing the moans and atardard doviatione of the books 1 or the above $1 x$ wenuran. That it, the mean and etandard deviation of Book I was comparedth the moan and standard deviation of Books If, III, IV and $v$, for vocabulary bejond 6047, oto.

When compared for the per cent of fords lying withn the acoepted range of 5047 , $^{16}$ Book III was the only book of the 11 ve which showed 97 per cont ${ }^{17}$ of 1 to rocabalary to bo within 6047. Books I and II ranked the same with 96.5 per cent

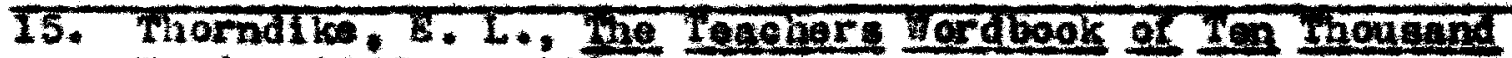
vioras. 1923, p. is I.

16. Vocabulary Ranje baed on Throndike, Terman, and Metropolltan Achievewent Tests, op. alt., Chapter III, p. 46.

17. Autho* a arbitrary vocabulary standard, op.cit. Chapter III. p. 67 . 
of their roenbulary below 6047. Book II, however, had $\mathbf{2 . 2}$ per eent of the remalning 3,3 per oent beyond 10,000 , while Book I had only 1.7 per cont beyond 10,000. All the booke had a Bignificant per oant of worda beyond the 6047 frequency, however.

Book III. may be satd to oontain the amaileat number of unooknon worde and Book IV the largest number of thew.

2. Compared $f$ or sentenoe-length, the ast algnificant differmee was found botwoen Books II and $\mathrm{IV}$. The loast difference wao between Books II and III. Aa deterwined by the difference twaen ans, Books II and IV were difforent to marked degres, and Books II and III were moh alks.

3. Fhen compared or the number of phrases to the paragraph, Book II ranked hath, and Book I low. Statistical comparison of the weans showed algmiflcant differenos bo tween Books I and III and Books II and III.

4. No of insfioant differenos was found between any of the books when compared for the number of sentences to the paragraph. The igrotsest asterenoe, though smail, wa again between Booke II and IV. Then ranked for mumbr of sentences to the paragrarh. Book III was 100 and Book II high.

5. There are warkod difforoned betwoen the books when compared for the number of prords to the mentence. Blgniflcant

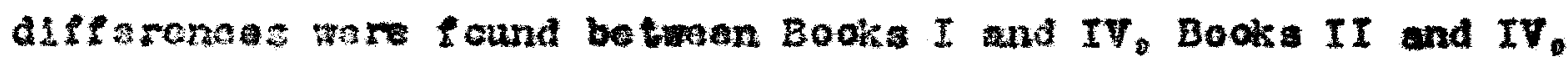
Dooks II: and IV, and Books IV and $\mathrm{Y}$. Book IV herg was most 
undike the other books, the greateat differenes being betwoen 1 t and Book II, Books $I$ and II, and Books II and III show the least differenas when comparad for the mamber of words to the sentenoe.

Stgnifioant differences ware found botween the thandind devtations fors Books I and II, Books I and III. Books I and.IV and Books I and $V$.

3. Ranked $t$ or the nuber of phrases to the antence, Book IV was high and Book I low.

Book IV and $V$ show a tharked difforence. but the

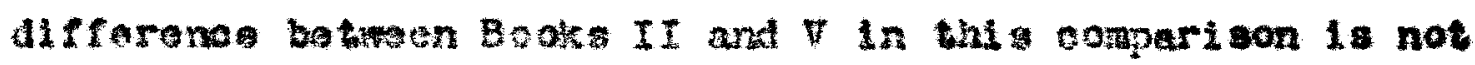
sigmifloant. Books I and II appoar much aliks, as do Book II and $\nabla$. Slgnifleant diffarences are found between Book. I and II, I and IV, III and IV, II and V, III and I, and II and III.

Aook IV is most oonal atently unlike the other four books. It has the hichest roosbulary. the longent sentenoes, tho longest pirrass:s, and the most phranes to the entenoe. In number of asntenoes to lie paragraph it ranke with Book I. Bonk IV, however, has an averaze of 19.71 words to tho sentence, whle Book I has only 14.00 rorda. In phrases to the paragraph. Book IV rank emrth then average of 14.45 phrases bo the paragraph th th a man ward-length of 7.11. Book $V$ is more like Book IV than the other books, whlle Book II I nearest 11ke Book V. Book I and Book III are moch allke. Book III has Ionger watences then Book I and wore phrases to the sentenoe. The po phrases, howevar, are short. with an average of 5.89 word so the phrase. 
H. Further Analyeis of the Five History Books in the pepect to the Suitabili ty lor sixth-A Grade Pupils

\section{Vocabulary Range}

An inspeotion of Table XLIII, page 131, shows that Book III is the only one of the flre books with 97 per cent $(100.0 \%-3.0 \%)$ of its rocabulary within a frequenoy range of 6047 - the $11 \mathrm{mlt}$ arbitrarily established by the author as desirable for gixth-A grade children. (See page 67).

Book IV, th 95.4 per cent $(100.0 \%-4.6 \%)$ of its rocabulary winin the prescribed range, appears to have the most difficult vocabulary, though as shown in Table XLV page 136, only one of the differences between the per oent of words beyond 6047 is statistically reliable. It w111 be remenbered that all five of the books have a aigniflcant per cent of words beyond the 6047 irequency level.

2. Degree of Comprehengion with whioh Sixth-A Pupila head the Fire Booka

The reading age of all pupils used in this study was determined from their test performanosa on the Metropolitan Achlerement Tests ${ }^{16}$ and these ware compared with the degree of accuracy wh whlch they answered the questions on the teats of comprehenat on.

16. Metropolitan Achievement Tests, Intermediate BatteryPartial: Form $A$. For Grades 4; 5, and 6. Editad by Jac ob S. Orleans - 1932 . 
The individual soores of the children in the groups were equated for chronological age, mental age, and reading age, and were usod to set up age and grade categoriea, (no child belng used more than once). Table I to $V$. Appendix A. The pupils from School A, who were tested on Book I were grouped in age and grade categories acoording to the age and grade norms on the Netropolitan Achlevenent Teste. The se are shown in Table LXVIII, page 182. All children having a reading age of 9 years and 5 monthe were placed in the grade-norm group of $4.1,4.1$ being the gradenorm for puplis making a reading age of 9-5 years. All pupils scoring a reading age of 9-10 years were placed in the 4.4 grade-norm category, etc.

The number of children reading in each group was tabulated and converted into the per cent of the total number of obildren taking the test. Thus 8.1 per cent of the pup11 in Group I were reading at a 4.1 grade level as deternined by the Hetropolitan Achievement Tegt, 13.5 per cent rere reading at 6.8 level, and 8.1 per cent were reading at a lovel above 6.8 level (Table LXVII).

The number of correct responses to the tests of comprehengion was tabulated for each age and grade stop. Correot responses, or scores, were converted into per oents by dividing the number uf correct responses in each step by the total possible scores. These are called per cents of accuracy. 
The puplis in step 9-5, for example, answered the tests of comprehension on Book I with 54 per cent accuracy. The pupl1s in step 12-5 answered with 92 per cant acuracy. The number of minutes used by ach child to complete the tests wes tabulated for each step and these wero averaged.

13.5 per cent of the pupils of Group I were reading at a grade 6.8 lovel. They read the serenteen seleotions from Book $I$, and answered the questions on ther ia an avarage of 25 minutes.

Since the pupils used in this study had been in the sixth grade elght months, 6.8 was used as their grade level and 12-5 years as their raading age. (Chapter III, p.70). A book was considered as sultable $f$ or them if they oould read it with 75 per eent accuracy. These children (6.8 grade, 12-5 years) read Book I f or example with 92 per cent accuracy. 78.4 per cent of the group (steps 10-0 to 12-5) read it ith a dagrese of acouracy above 75 per cent.

It w11 be gen that there is a gradual though irregalar increase in the amount the puptis comprehended with a corresponding increase in reading age. The amount of the taken to finish the tests decreases as the reading ability 1ncreases. (See Table LXVII, page 172).

By the above crttaria, Dook I, Europe the Hother of Anerica, by Horne and Bucks may be accepted as suitable for Group I since the flve groups are comparable in 
terms of cironological ace, mental age, and reading age. Book I may be sald to be reasonably suitable in comprehensibility for the groups from each of the five schools.

\section{TABLE LXVIII}

AGE AND GRADE NORUS FROU THE ERTROPOLITAN ACHIBVEMENT TESTS, AVERAGE WU:ABER OF PUDILS IN EACH AGE AND GRADE CATEGORY, AVERAGR SCORE, PER CENT OF ACCURACY. AND TIUE TO COMPLETE HISTORY COUPREHENSION TESTS

\section{Group I}

\begin{tabular}{|c|c|c|c|c|c|}
\hline Ase & Grade & $\begin{array}{l}\text { Per Cent } \\
\text { of Punils }\end{array}$ & $\begin{array}{c}\text { Average } \\
\text { Score } \\
\end{array}$ & $\begin{array}{l}\text { Per Cent } \\
\text { of Accuracy }\end{array}$ & Tlme \\
\hline $9-0$ & 0.0 & 0.0 & 0.0 & 0.0 & 0.0 \\
\hline $9-5$ & 4.1 & 0.1 & 44 & 64 & 32 \\
\hline $9-10$ & 4.4 & 5.4 & 47 & 69 & 41 \\
\hline $10-0$ & 4.6 & 10.8 & 54 & 79 & 40 \\
\hline $10-5$ & 4.10 & 10.8 & 54 & 79 & 40 \\
\hline $10-10$ & 5.3 & 16.3 & 57 & 83 & 28 \\
\hline $12-0$ & 5.5 & 8.1 & 60 & 88 & 25 \\
\hline $11-5$ & 5.9 & 5.4 & 62 & 91 & 35 \\
\hline $11-10$ & 6.3 & 8.1 & 61 & 89 & 29 \\
\hline $12-0$ & 6.4 & 5.4 & 63 & 92 & 27 \\
\hline $12-5$ & 6.8 & 13.5 & 63 & 92 & 25 \\
\hline $12-10$ & $7 \cdot 3$ & 8.1 & 62 & 91 & 25 \\
\hline $13-0$ & 7.5 & 0.0 & 0.0 & 0.0 & 0.0 \\
\hline $13-5$ & 7.9 & 0.0 & 0.0 & 0.0 & 0.0 \\
\hline $13-10$ & 8.4 & 0.0 & 0.0 & 0.0 & 0.0 \\
\hline
\end{tabular}


Table LXIX, page 174, gives the data $f$ or Group II, or the puplls tested on Book II.

The pupils were in Chronological-Age Group II, Mental Age Group II, and Reading Age Group II.

They re grouped In age and grade categorie by the sane procedures used for the children in Group I.

Inspeotion of Table LXIX show that the reading age range for this group is from 9-5 to $13-5$ years. 3.5 per cont of this group are at a grade lovel of 6.8 , and $12-5$ reading age. The se pupila answered the questions on Book II with 94 per cent accuracy in an average time of 30 minutes. 82.7 por oent of the group, not including those puplis beyond 12-5, answered the questions th an accuracy of 75 per cent or better. 72.4 per cent of the pup1ls were beyond 75 per cent accuracy.

It will be seen that comprehension increased with reading ability and that the amount of time required, deoreased. Both of these however, are irregular, and the 13-0 level fell below that of children with a reading age of two monthe less. Sinoe the pupils at the $12-5$ reading age lovel read Book II with 94 per cent accuracy, and 82.7 per cent of the group below the 12-10 level, read it with an accuracy of 75 per cent or better, the book, Our Nation's Heritage, by Halleck and Frantz may be acoepted as sultable for the se groups. 
TABLE LXIX

AGE AND GRADE NORUS FROM THE MRTROPOLITAN ACHIEVEURAT TESTS, AVERAGI NUUBER OF PUPILS IN BACH AGE AND GRADE CATEOOAY, AVERAGE SCORE, PER CENT OF ACCURACY, AND TI HE TO COMPLETE HISTORY COUPREHENSION TESTS

\begin{tabular}{|c|c|c|c|c|c|}
\hline \multirow[b]{2}{*}{ Age } & \multicolumn{3}{|c|}{ Group II } & \multirow[b]{2}{*}{$\begin{array}{l}\text { Per Cent } \\
\text { of Accuraer }\end{array}$} & \multirow[b]{2}{*}{ In: } \\
\hline & Grade & $\begin{array}{l}\text { Per Cont } \\
\text { of Pupils }\end{array}$ & $\begin{array}{l}\text { Average } \\
\text { Seore } \\
\end{array}$ & & \\
\hline $9-0$ & 3.7 & 0.0 & 0.0 & 0.0 & 0.0 \\
\hline $9-5$ & 4.1 & 0.0 & 0.0 & 0.0 & 0.0 \\
\hline $9-10$ & 4.4 & 6.9 & 41 & 60 & 45 \\
\hline $10=0$ & 4.6 & 10.3 & 51 & 75 & 49 \\
\hline $10-5$ & 4.10 & 13.7 & 52 & 76 & 43 \\
\hline $10-10$ & 5.3 & $10-3$ & 58 & 85 & 38 \\
\hline $11=0$ & 5.5 & 13.7 & 55 & 80 & 26 \\
\hline $11-5$ & 5.9 & 27.4 & 57 & 83 & 36 \\
\hline $11-20$ & 6.3 & 6.9 & 59 & 86 & 31 \\
\hline $12=0$ & 6.4 & 6.9 & 64 & 94 & 30 \\
\hline $12-5$ & 6.8 & 3.5 & 64 & 94 & 30 \\
\hline $12-10$ & 7.3 & 6.9 & 66 & 97 & $\mathbf{3}$ \\
\hline $13-0$ & 7.5 & 3.5 & 62 & 92 & 33 \\
\hline $13-5$ & 7.9 & 0.0 & 0.0 & 0.0 & 0.0 \\
\hline $13-10$ & 8.4 & 0.0 & 0.0 & 0.0 & 0.0 \\
\hline
\end{tabular}


Table LXX, page 176, gives the data for Group III, or the pupils tosted on Book III.

Age level 12-5 shows that 14.7 per cent of the group were at a 6.8 grade level.

Of the pup12s in Group III, 7.4 per cent had a reading ability of 10-0 years. They scored 71 per cent accuracy.

There is a large inerease, however, in the degree of accuracy from the 10-0 to the 10-5 step. There is a continuous increase in per cent of accuracy with an inorease In reading ability. The scores, however, are bunched, wi th a large increase at the $10-5$ and $13-0$ levels.

Since 75.6 per cent of the group answered the questions with an accuracy of 75 per cent or better, Book III, Our Old World Beginninss, by Kelty, way be consldered accoptablo for the groups who use 1 t. 


\section{TABLE LXX}

AGE AND GRADE NORIS FRON THE METROPOLITAN ACHIEVEMENT TESTS, AVRRAGE NUTBER OE PUPILS IN EACH AGR AND GRADR CATEGORY, AVERAGE SCORE, PER CENT OF ACCURACY, AND TIME TO CONPLETE UISTORY GOUPREHENSTON TESTS

\begin{tabular}{|c|c|c|c|c|c|}
\hline \multirow[b]{2}{*}{$A g e$} & \multicolumn{3}{|c|}{ Group III } & \multirow[b]{2}{*}{$\begin{array}{l}\text { Per Cont } \\
\text { of Acoureor }\end{array}$} & \multirow[b]{2}{*}{ Ma } \\
\hline & Grade & $\begin{array}{l}\text { Por Cent } \\
\text { of Papils }\end{array}$ & $\begin{array}{l}\text { Averago } \\
\text { Soore }\end{array}$ & & \\
\hline $9-0$ & 3.7 & 0.0 & 0.0 & 0.0 & 0.0 \\
\hline $9-5$ & 4.1 & 4.9 & 39 & 54 & 43 \\
\hline $9-10$ & 4.4 & $2 \cdot 4$ & 51 & 61 & 36 \\
\hline $10-0$ & 4.6 & $7 \cdot 4$ & 58 & 71 & 40 \\
\hline $10-5$ & 4.10 & 7.4 & 62 & 87 & 36 \\
\hline $10-10$ & $5 \cdot 3$ & 9.7 & 63 & 88 & 36 \\
\hline $11-0$ & 5.5 & $12 \cdot 2$ & 64 & 90 & 35 \\
\hline $11-5$ & 5.9 & 9.7 & 64 & 90 & 29 \\
\hline $11-10$ & 6.3 & 9.7 & 65 & 91 & 32 \\
\hline $12-0$ & 6.4 & 12.2 & 65 & 91 & 89 \\
\hline $12-5$ & 6.8 & 14.7 & 66 & 93 & 24 \\
\hline $12-10$ & $7 \cdot 3$ & 4.9 & 65 & 91 & 26 \\
\hline $13-0$ & 7.5 & 2.4 & 67 & 95 & 30 \\
\hline $13-5$ & 7.9 & 2.4 & 67 & 95 & 38 \\
\hline $13-10$ & 8.4 & 0.0 & 0.0 & 0.0 & 0.0 \\
\hline
\end{tabular}


Table LXXI, page 178, gives the data for Group IV, tested on sook IV.

15.7 per cent of the ohildren in this group had a roading age of 12.5 yoars. Thay read the seloctions with an acouracy of 88 per cent in 46 milnutes.

The soores in oroup IV are omathat lower than those of aroups I. II, and III, and the tI ne woh longer. There is an inorease in the por cent of accuraoy with reading age. But there is 11 thle change between the scores from the 10-5 age lavel to the 13-5 level.

The notiecable increase in the time uaed by the pupil. may man that the reading was diftloult and the ohildren apent a longer thise on trying to couprehend its maning. Or It mean that the se ohlldren ware slowar workers.

wi th 93.9 per cent of the group sooring a 10-0 reading age level on the Metropolltan Acilevement Tegle, which are time teats. this ia probably not the cause. They do not appear to bo al oworkers.

of the so childron 84.5 par cent wi th a reading level below 12-10, answered the questions th a degree of accuracy beyond 75 por cent. Fros this ariterion, Book IV. The American People and Thair Old Rorld Anceatorg. by Vollintine 1. oultable for the groups that road 16. But the time expended by these ohllaren may wean that the book is too difflemit. The average class period for the upper sixth grade is 30 minutes. 46 minutes to read and anewer quotione on seventeen paraeraphs man too great an expendi ture of tine for the resulta ob tained. 
TABLE LXXI

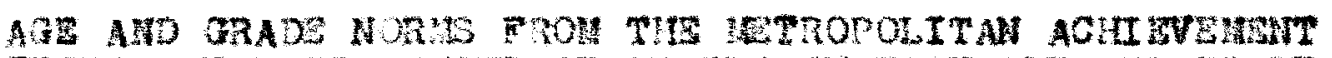
Tats, AVZRATE WUIBER OF PUPILS IN BACH AGE AND GRADE

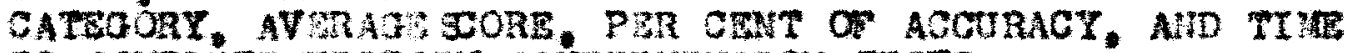

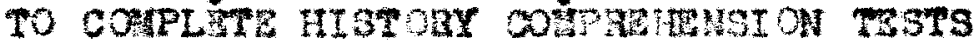

\begin{tabular}{|c|c|c|c|c|c|}
\hline & & Group IV & & & \\
\hline Age & arade & $\begin{array}{l}\text { For Cont } \\
\text { of Pupile }\end{array}$ & $\begin{array}{l}\text { Avorage } \\
\text { Soore }\end{array}$ & $\begin{array}{l}\text { Per Cent } \\
\text { of Aceuraex }\end{array}$ & $\mathrm{Trme}$ \\
\hline $9-0$ & 3.7 & 0.0 & 0.0 & 0.0 & 0.0 \\
\hline $9-5$ & 4.1 & 0.0 & 0.0 & 0.0 & 0.0 \\
\hline $9-10$ & 4.4 & 6.3 & 43 & 63 & 62 \\
\hline $10=0$ & 4.6 & 3.1 & 54 & 79 & 47 \\
\hline $10-5$ & 4.10 & 12.5 & 58 & 85 & 38 \\
\hline $10-10$ & 5.3 & 9.4 & 60 & 85 & 54 \\
\hline $11-0$ & 5.5 & 13.5 & 58 & 85 & 41 \\
\hline $11-5$ & 5.9 & 12.5 & 57 & 93 & 43 \\
\hline $12-10$ & 6.3 & 9.4 & 58 & 85 & 49 \\
\hline 120 & 6.4 & 9.4 & 57 & 86 & 31 \\
\hline $12-5$ & 6.8 & 15.7 & 60 & 88 & 46 \\
\hline $18-10$ & 7.3 & 3.1 & 54 & 94 & 26 \\
\hline $13-0$ & 7.5 & 0.0 & 0.0 & 0.0 & 0.0 \\
\hline $13-5$ & 7.9 & 6.3 & 67 & 98 & $\mathbf{3 2}$ \\
\hline $13-10$ & 8.4 & 0.0 & 0.0 & 0.0 & 0.0 \\
\hline
\end{tabular}


Table LXXII, page 180, atves the data for Group $v$. the chlldren tested on Book $v$.

6.8 por cent of these chlldrsn hava a reading age of 12-5 yoars. They read the selections from Book $V$ of th 95 per cent accuracy in 16 minutes.

14.3 per cont of the group wero at a 12-0 age level. They ared 91 per cent accuracy in 20 minates. 85.2 per cont of the group answered the questions with an accuracy of 75 per oent or better.

There is a gradual though irregular inorease in the number of correct reaponses with an inorease wh theading age. and a deorease in the number of minutes used to oomple the teats.

The difference between the length of the used by Groupa IV and $V$ to complete the testa of comprohongi on Is very marked.

The ohlidren of aroup IV scored 79 par cent acouraoy in 47 minutes at an age leval of 10 mo years. The children of croup $\checkmark$ scored 88 per cent accuracy in 25 minutes at the ane age 10vel.

Group IV acored 88 per cant accuracy in 45 minutes at an age lavel of 12-5 yeara. Group $V$ gcored 95 per oent acouracy in 16 minutes at the $12-5$ level. Thus Book $V$ appears moh easier to understand than Book IV.

3inee the pupila at the age level of $12-5$ yoaro read Book $V$ with 95 por cent acouracy, and atnoe 85.8 per cent of the group wored 75 per oent or better. The Blabentary World Flatory. by Beard and Bagley is considered auitable for the groups that use it. 
TABLE LXXII

AGE AND GRADE HOR WS FROM THE UETROPOLIT W ACHIEVEIENT TESTS, AVERAGE NURBBR OF PUPILS IN EACH AGE AND GRADE CATEGORY, AVERAOE SCORE, PER CEAT OF ACCURACY, AND TIRE TO COMPLETE HISTORY COHPREHENSION TESTS

\begin{tabular}{|c|c|c|c|c|c|}
\hline \multirow[b]{2}{*}{$\mathrm{Ag} \bullet$} & \multicolumn{3}{|c|}{ Group $V$} & \multirow[b]{2}{*}{$\begin{array}{l}\text { Fer Cent } \\
\text { of Aoguraey }\end{array}$} & \multirow[b]{2}{*}{ TI } \\
\hline & Grade & $\begin{array}{l}\text { Per Cont } \\
\text { of Pupila }\end{array}$ & $\begin{array}{l}\text { Average } \\
\text { Seore }\end{array}$ & & \\
\hline $9-0$ & 3.7 & 0.0 & 0.0 & 0.0 & 0.0 \\
\hline $9-5$ & 4.1 & 5.7 & 50 & 71 & 36 \\
\hline $9-10$ & 4.4 & 8.6 & 53 & 75 & 38 \\
\hline $10=0$ & 4.6 & 21.4 & 62 & 88 & 25 \\
\hline $10-5$ & 4.20 & 8.6 & 62 & 88 & 26 \\
\hline $10-10$ & 5.3 & 5.7 & 60 & 85 & 22 \\
\hline $11-0$ & 5.5 & 8.6 & 66 & 94 & 23 \\
\hline $11-5$ & 5.9 & 8.6 & 65 & 92 & 23 \\
\hline $11-10$ & 6.3 & 11.4 & 66 & 94 & 26 \\
\hline $12-0$ & 6.4 & 14.3 & 64 & 91 & 20 \\
\hline $12-5$ & 6.8 & 8.6 & 67 & 95 & 16 \\
\hline $12-10$ & $7 \cdot 3$ & 5.7 & 66 & 94 & 14 \\
\hline $13-0$ & 7.5 & 0.0 & 0.0 & 0.0 & 0.0 \\
\hline $13-5$ & 7.9 & 2.8 & 66 & 94 & 15 \\
\hline $13-10$ & 8.4 & 0.0 & 0.0 & 0.0 & 0.0 \\
\hline
\end{tabular}


Table LXXIII brings the data from the five groupa together in summary, (page 182).

It gives the following for ach age and grade step for the five groups.

1. Reading age

2. Grade norm

3. Per cent of aocuracy

4. Average time

The dotted line below the age level 12-5 is the normal poation $f$ or the average of children who are in the elghth gonth of the sixth grade. It showe that the five books were read and the question answered wh the following degree of accuracy. Group averages are given the bottom of the table. 
TABLE LXXIII

READING AGE, PER CENT OF AGCURACX ON HISTORY ACHIEVEMENT TEST, AVPRAGE TIME IN COMPLETION OF TEST AND AGE - GRADE NORY OF METROPOLITAN ACIIIEVELENT TESTE

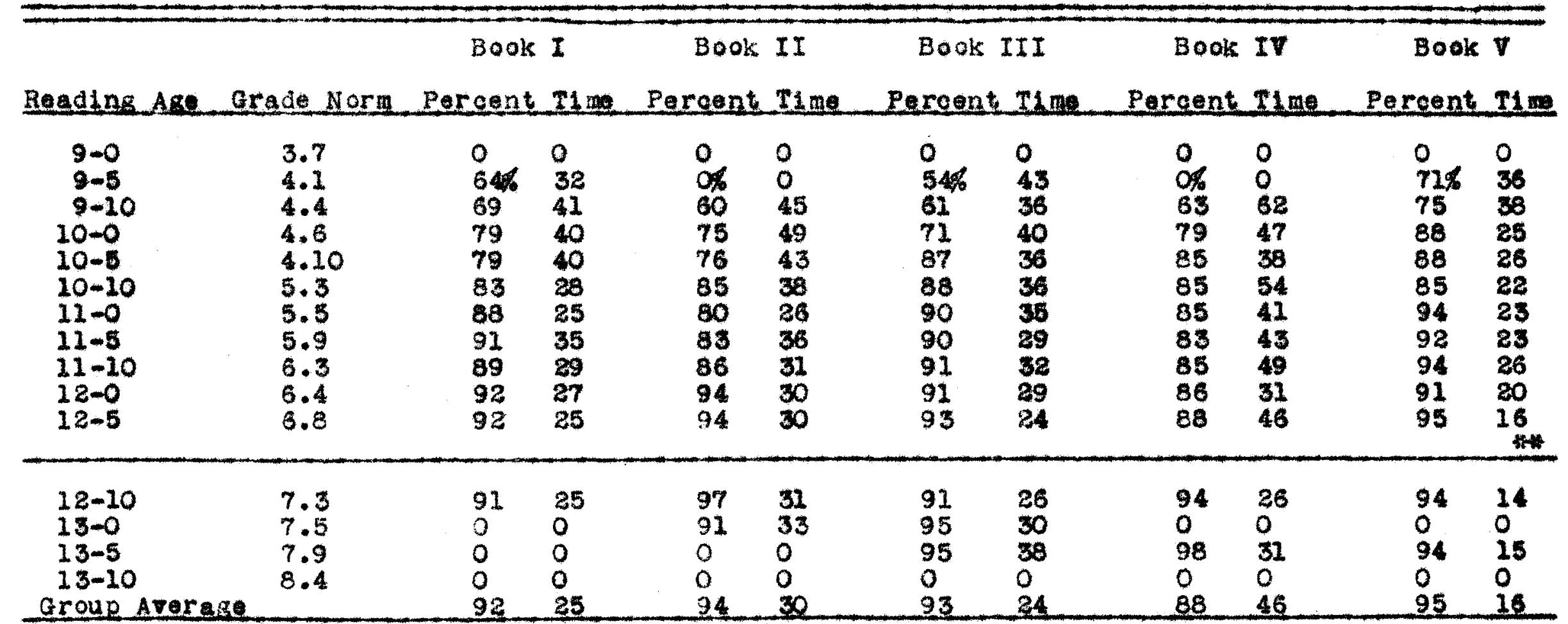

* Metropolltan Achlevement Tests, Intermediate Battery - Partial: Form A. For Grades 4, 5, and 6. World Book Company, Yonkers-on-Hudson, New York, 1932.

* Metropolitan Aohleregent Tests Ago-arade Norm for upper S1 xth Grade.

Sinee 75 per cent is considered a batlsfactory degree of accuracy, the ive history books appear to be well within the understanding of the group who read them. 
30WEAT POE TUE SUITABILITY OF THE FIVE HISTORY BOOKB

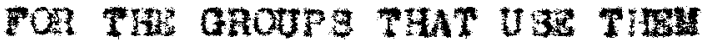

The five books were judged as antable for the children usind thon if:

1. 97 per cent of the rocabulary was win the 6047 rango on the thorndike Froqueney of Jarke Boale

2. The selectiona ware read th a degree of ooaprehensi on of not las than 75 per cont

Book III was the only one of the flve books having 97 per cent of 1 ts vocabulary within the 6047 range. A comparison of the five books for the per cent of worde beyond 6047, shas a stgniflont difterence between Books III and IV.

A11 of the books were raad with a degree of accuracy above 75 per cont by puplis who scorad a reading age of 12-5 on the Metropolitan Achlevement Tests. Book $V$ being the asiest and Book IV the most diflloult. In degree of comprehension with winteh the books are read by pupils typloal of this grate level they rank, then at follows: Book V, aaleat, Book II, next eagiat; then Dook III. Book I, next, and Book IV, most dif loult. 
THS DEGREE OF COMPREHENSION THE FIVE SUPPLEHENTARY HISTORY BOOKS

WRRE READ BY SIXTH-A GUILDREN 


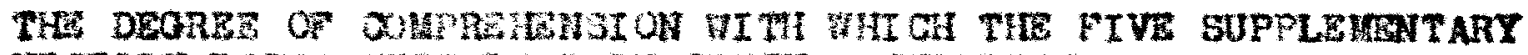
HISTORT BOOB 5 WRT PEAD BT SIXTH-A CHLDREN

A. Equating the Groupe

The pup12s used in this study are equated on tiree bases as described in chapter III.

1. Chronologieal Age

2. Mental Age

3. Reading Age

The baslo data for all pupliz in the flve groups -quated on chronologlcal age are giren in Tables I. II. III. IV, and $V$. Appendi $X$.

Table I isives the basto data for Group I. Group I consists of all stxth-A puplis fron sehool $A$ who read the soloctions and answered the questions on Book I. Europe the Lotior of America, by Horne and Bucks.

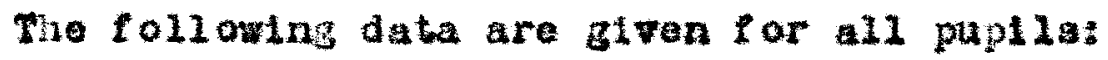

1. sex

2. Cironologieal Age

3. Mental Age

4. Intalilgent quotient

5. Reading Ago

6. Soore or degree of accuracy with which the selections were read and the quostions answered

7. Time taken to read the espotions and anawar the questions 
The twenty-one puplis whose C.A. Is not preceded by atar are the children used to make up the Chronological Age Groups. Those puplls under M.A. not preoeded by two stars comprise the Hental Age Groups. Those pupils under R.A. not preceded by three atars comprise the Reading Age Groups.

Table II gives the data for all sixth-A pupils from Sehool B who read the selections and answered the questions on Book II, Our Hation's Heritege, by Halleok and Frantz.

Table III gives the data for all sixth-A puplis from Sohool. C who read the selections and took the tests on Book III, The old World Beginnings, by Kelty.

Table IV gives the data for all sixth-A chlidren who read the samplings and took the tests of comprehengi on on Book IV, The Amerloan People and Their Old por ld Ancestorg, by Vollintine.

Table $V$ gives the data for all sixth-A children who read the seloctions and answered the questions on the tests of comprehension on Book $V$. The Elementary For Id Higtory, by Beard and Bagley.

1. Equation of Groups on Chronological Age

Trenty-one puptls from each of the pive groups (one group froin each sohool) were paired on sex and ohronologleal age.

The Pirst pupil in Group I is a girl eloven years and alx montha old. She is paired with a pupil in each of the 
other four groups of the same sex and age. The second pup11, who is also girl, is eleven years and five montha old. The second pupli in Group IV is eleven years and four wonths old. The second pupil is, then, paired with four identical girls, and afth of as near identical age as it was possible to get it. All other pupils are paired in the same manner. (Tables I, II, III, IV, and $V$, Appendix $A$ ).

since the writer is here conoerned th the means of the groups and not with individual children, it is not required that all the subjects participating be identioal. It means that all the groups partiolpating be equivalent. To be equivalent the various groups must have $11 \mathrm{ke}$ means and Iike varlabilities among the subjects constituting each group. 1

The statiotical data for the five groups aquated on chronological age are given in Table LXXIV, page 188. The data for the five groups are:

1. Means

2. Standard deviations of the distributions

3. Probable errors of the distributions

1. MoCall, William $A$, How to Experiment in Education. 1930, pp. 40-41. 
4. Probable errors of the meane

5. Standard errors of the means

6. 3tandard errors of the standard deviations

The first horizontal oolumn in Table LXXIV shows the means of the flve groups to be identical. The second colum show the standard deviations. The re is a slight variation in the standard deviations of the fire groups. Table LXXV, page 190, gives comparison of the means and standard deviations to determine whother these differences are significant or not significant.

Table LXXV shows the means of the five groups to be identical. The differences between standard deviations must be at least three times their probable errors to be signifioant. 2 sinoe all are $10 \mathrm{ss}$ than 3.00 , the differences are not aignifieant.

The five groups equated on sex and chronological age are, then, equivalent groupa. Results of a Certain Accuracy." Journal of Applied Psychology. Volume, 21, 1937, p. 5 . 
TABLE LXXIV

DATA OF THE FIVE GROUPS DQUATED FOR CIRONOLOGICAL AGE

\begin{tabular}{|c|c|c|c|c|c|}
\hline & $\begin{array}{r}\text { Chr } \\
\text { Group I } \\
\end{array}$ & $\begin{array}{l}\text { gologloal } \\
\text { Group II }\end{array}$ & $\begin{array}{l}\text { Ag* } \\
\text { Group III }\end{array}$ & Group IV & Group \\
\hline Mean & 12.00 & 12.00 & 12.00 & 12.00 & 12.00 \\
\hline $\begin{array}{l}\text { Standerd } \\
\text { Deviation }\end{array}$ & 7.30 & 8.05 & 7.44 & 7.00 & 7.25 \\
\hline $\begin{array}{l}\text { Probable } \\
\text { Error }\end{array}$ & 4.856 & 5.429 & 5.011 & 4.721 & 4.792 \\
\hline $\begin{array}{l}\text { Probable } \\
\text { Error of } \\
\text { mean }\end{array}$ & 1.080 & 1.212 & 1.124 & 1.055 & 1.070 \\
\hline $\begin{array}{l}\text { Standard } \\
\text { Error } \\
\text { of Mean }\end{array}$ & 1.601 & 1.779 & 1.809 & 1.705 & 1.586 \\
\hline $\begin{array}{l}\text { Standard } \\
\text { Error } \\
\text { of the } \\
\text { Standard } \\
\text { Deviation }\end{array}$ & 1.111 & 1.244 & 1.142 & 1.086 & 1.111 \\
\hline
\end{tabular}

Table LXXIV gives the data of the fire groups equated on sex and chronologlcal age. The first horizontal colum gives the neans of the flve group. The second horizontal colum gives the standard deviations of the distributions of the five groupa; the third the probable errors, ete.

The means of the tive groups are identioal. The slight variation between the standard deviations are not significant. (Table LXXV, p. 190). 
KEY TO THE FOLLOIING TABLES LXXV, LXXVII, LXXIX

$u_{A}-\mathbb{u}_{B}$

Dife.

P.E. atfi.

Diff.p.z.diff

$\sigma_{A}-\sigma_{B}$

Diff.

P. D.diff.

Diff./P.E. alit.

Significant?
Differences between the Means of Groups I and II, $I$ and III, I and IV, etc.

Difference between Means

Probable Error of difference between Means

Differenoe between Heans divided by their Probable Errors

Differences between the Standard Derlations of Groups I and II, I and III, I and IV, etc.

Difference between Stendard Deriations

Probable Error of difference botween standard Derlations Difference between standard Devietions divided by their Probable Errors.

If a differenoe divided by 1 ts probable error 1 s 3.0 or more, it is considered signifloant; if loss, it is considered not signif lcant. The se are indicated by "Yes" or "No." (Link, H.C., "How Many Interviews Are Necessary tor Results of a Certain Accuracy," Journal of Applied

Psychology, Volume 21, 1937, p.5.) 
TABLE LXXXV

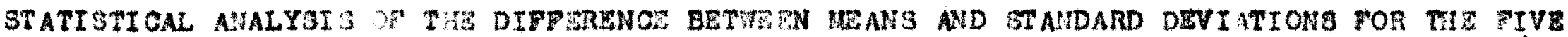
OROUPB EQVATED ON CIRONOLOGICAL ATE

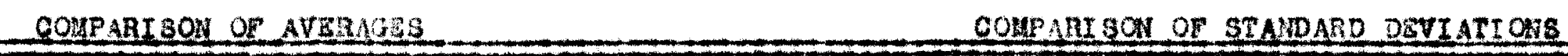

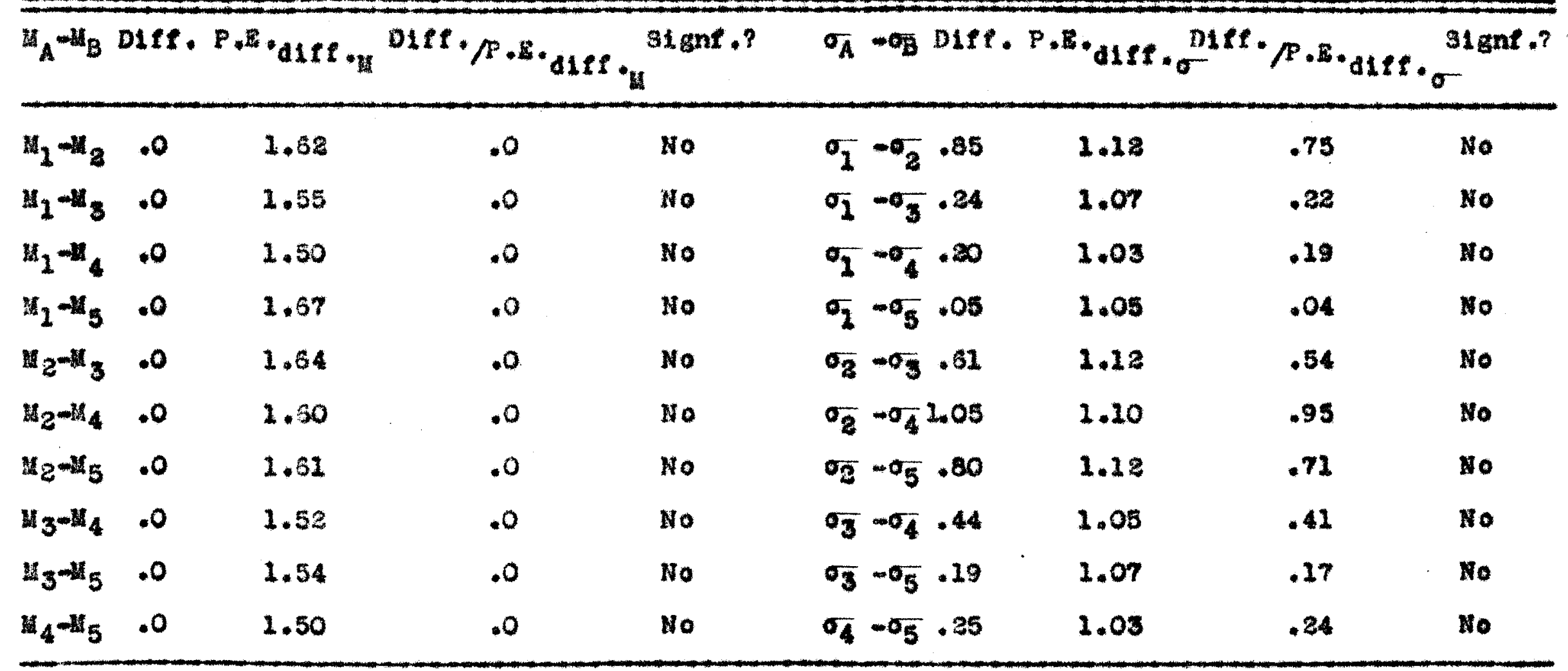

Table LXXY show the five groups equated on Chronologleal Age to be equivalent groups, sine tho differenee between the treans are 0.00 and he differences between the atandard deviations not signitiont. 
2. Equation of aroups on Hental Age

Twenty-one pupila from each of five groupa (one group from each achool) were paired on sex and mental age. 3 The mental ages used in making the pairings were taken from the children's performance on the otis Self-Administering Test of Mental Ability, ${ }^{4}$ which had been given to all elxth-A pupils.

All mental ages were convorted into quotients by dividing the wental age in months by the ohronological age in months. 5

Each boy and girl was paired with four other pup11 a of the same sex and as nearly identical mental age as oould be procured from the 172 pupils used in selecting the fire equated eroups. (Tabies I, II, III, IV, and V, Appendix A). Statistical computations were used for determining the equivalency of the groups. The statiatical data for the Ire equivalent groups making up the Mental Age Group are given in Table LXXVI, page 193.

3. The computation of mental age is explained in Terman's, The Meagurement of Intell1genoe, 1926, pp. $137 \mathrm{ff}$.

4. Otis Solf-Administoring Testg or Mental Ability, by Arthur S. Otis, 1928.

5. HeCall, Fillam A.. How to Experiment in Education. 1930, pp. $53-60$. 
The means and standard deviation of the se groups are:

$\begin{array}{lll}\text { Group I } & 93.50 & 12.95 \\ \text { Group II } & 93.50 & 12.90 \\ \text { Group III } & 93.60 & 13.22 \\ \text { Group IV } & 93.00 & 10.81 \\ \text { Group V } & 93.60 & 15.61\end{array}$

Comparisons of these means and varlabilities for significance of differences are given in Table LXXVII, page 194.

The fourth column of Table LXXVII shows the differences between the means divided by their probable errors. Since all are 2ess than 3.00 , there are no gignifloant differences between means.

The differences between standard deviations, given in the serenth colum, show them to be less than three times their probable errors. Therefore the differences are not slgnifleant.

The live groups quated on mental age may then be cald to be equivalent groups. 
TABLE LXXVI

DATA OF THE FIVE GROUPS EQUATBD FOR MENTAL AGE

\section{Mental Age}

Group I Group II Group III Group IV Group V

\begin{tabular}{lccccc} 
Mean & 93.50 & 93.50 & 93.60 & 93.00 & 93.50 \\
$\begin{array}{l}\text { Standard } \\
\text { Deriation }\end{array}$ & 12.95 & 12.90 & 13.22 & 10.81 & 15.61 \\
$\begin{array}{l}\text { Probable } \\
\text { Error }\end{array}$ & 8.733 & 8.700 & 8.900 & 7.291 & 10.222 \\
$\begin{array}{l}\text { Probable } \\
\text { Error of } \\
\text { Moan }\end{array}$ & 1.954 & 1.904 & 1.992 & 1.638 & 2.281 \\
$\begin{array}{l}\text { Standard } \\
\text { Errors of } \\
\text { Mean }\end{array}$ & 2.876 & 2.876 & 2.950 & 2.417 & 3.380 \\
$\begin{array}{l}\text { Standard } \\
\text { Error } \\
\text { of the } \\
\text { Standard } \\
\text { Deviation }\end{array}$ & 1.999 & 1.999 & 2.042 & 1.766 & 2.400 \\
\hline
\end{tabular}

Table LXXVI gives the date for the groups equated on sex and mental age. The first horizontal colum gives the means of the flre groups. The second horlzontal oolumn gives the standard deviations of the groups; the third colum the probable errors, ete.

A comparison of the neans and standard deviations for al gnifleance of differences is given in Table LXXVII, page 194. 
TABLZ LXXVII

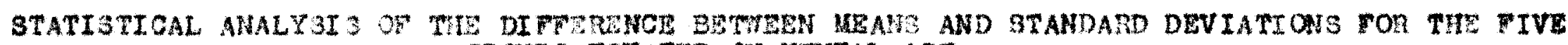
GROUPS EQUATED ON MZNTAL AGE

CONARESON OE AV IRASE3 COSTAESON OF STAMDARD DEVIATIONS

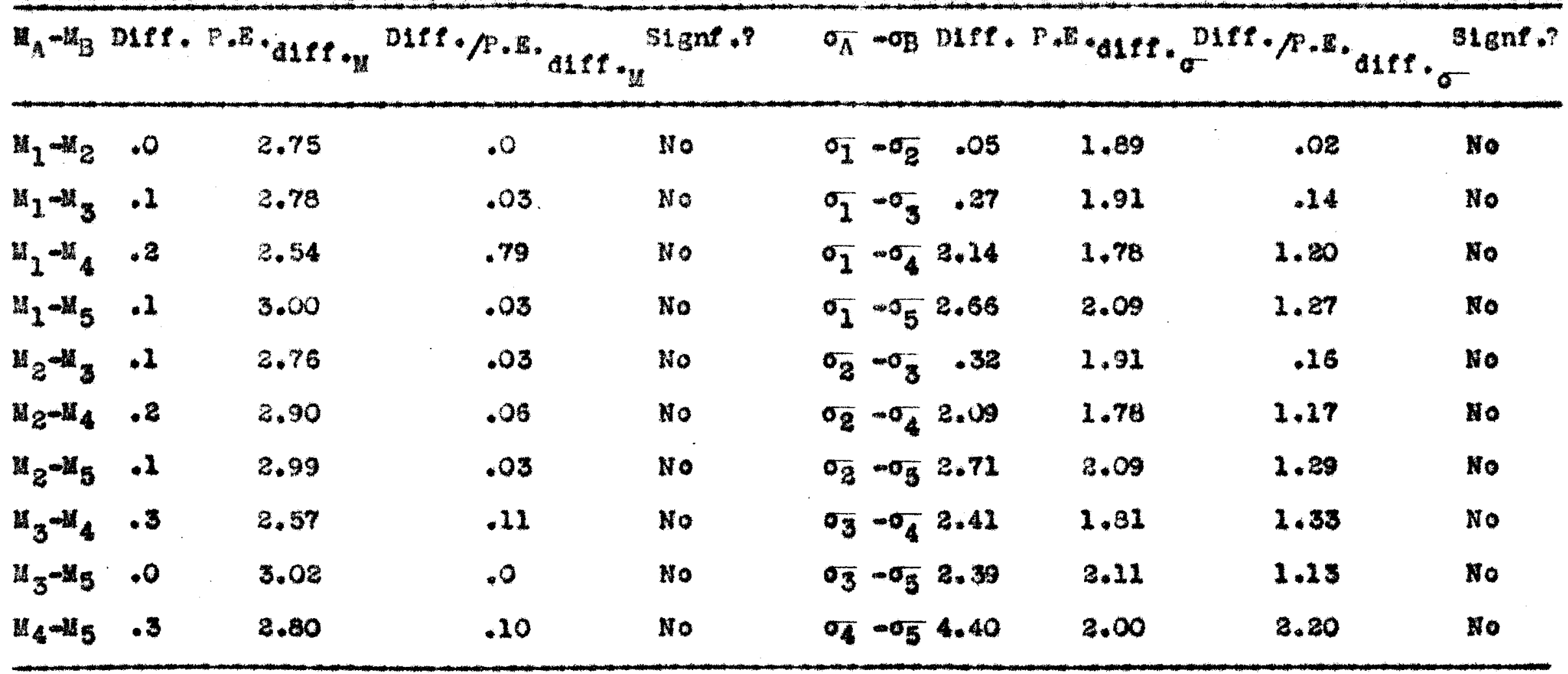

Table LXXVII show the flve groups equated on Uental Age to be equivalent groups, sinee the differences betweon the means and standard deviations are not sizmiflcant. 
3. Equation of Groups on Reading Age

Twenty-one pupils from each of the five groups (one group from each school) were palred on sex and roading age. The reading ages were taken from test performance on the Metropolitan Achlevement Teats. 6

All reading ages were converted into quotients by dividing the reading age in month by the chronologlcal age in months, 7 the chronological age belng the natal age at the time the tests were given. (Tables I, II, III, IV, and $V$, Appendi $x A$ ).

The data for the five groups are given in Table LXXVIII, page 197 .

The means and standard deviations of the group are:

\begin{tabular}{llc} 
& Heans & Standard Deviations \\
\hline Group I & 91.50 & 9.65 \\
Group II & 91.40 & 7.69 \\
Group III & 91.90 & 9.60 \\
Group IV & 91.50 & 6.74 \\
Group V & 91.40 & 9.48 \\
\hline
\end{tabular}

6. Metropolitan Aohievement Tests, Intermediato BatteryPartial: Form A. For Grades 4, 5, and 6 . Edited by Jacob S. Orleans. 1932.

7. HoCall, William A., How to Experiment in Equation. 1930, pp. 59-60. 
The comparisons of those means and standard deviation for algniflaanoe of differences are given in Table LXXIX. page 198.

None of the diffarences divided by their probable errors are signif lcant.

The difforences betweon standard devlations divided by probablo orrors show the dffereno between the variabllities to bo not significant.

The five groups equated on sax and reading age are -quivalont since thoy have equivalent abans and variabilitios." 
TABLE LXVIII

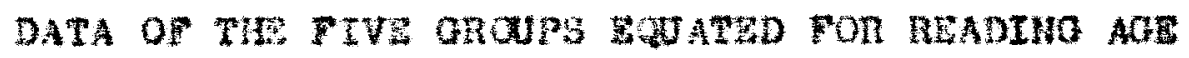

Reading

\begin{tabular}{|c|c|c|c|c|c|}
\hline & Group I & Group II & Group III & Group IV & Group V \\
\hline Mean & 91.50 & 91.40 & 91.90 & 91.50 & 91.40 \\
\hline $\begin{array}{l}\text { Standard } \\
\text { Devlation }\end{array}$ & 9.85 & 7.59 & 9.60 & 6.74 & 9.46 \\
\hline $\begin{array}{l}\text { Probable } \\
\text { Srror }\end{array}$ & 6.500 & 5.186 & 6.474 & 4.546 & 6.394 \\
\hline $\begin{array}{l}\text { Probable } \\
\text { Mrror of } \\
\text { Mean }\end{array}$ & 1.452 & 1.211 & 1.444 & 1.011 & 1.425 \\
\hline $\begin{array}{l}\text { Btandard } \\
\text { Error of } \\
\text { Nom }\end{array}$ & 2.150 & $x .794$ & 2.135 & 1.497 & 2.105 \\
\hline $\begin{array}{l}\text { Standard } \\
\text { Brror of } \\
\text { the } \\
\text { Btandard } \\
\text { Deviation }\end{array}$ & 1.484 & 1.188 & 2.481 & 1.044 & 1.462 \\
\hline
\end{tabular}

Table LXXVIII glves the data for the groups equated on sex and reading age. The flrst horizontal colum gives the taeang of tho five groups. The second horlzontal colun glves the standard deviations of the groups; the third colum the probabla arrors, ate.

A conparison of the seans and variabilitles for atgnifleant diffaronces a given in table LXXXX, page 198. 


\section{TABLE LXXIX}

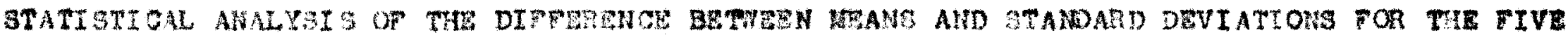
OROUT'S SQUATED OH READIVG AOE

\section{COYTARISON OW BVAOES}

\section{COHSAISOON OF STANDARD DEVIATYONS}

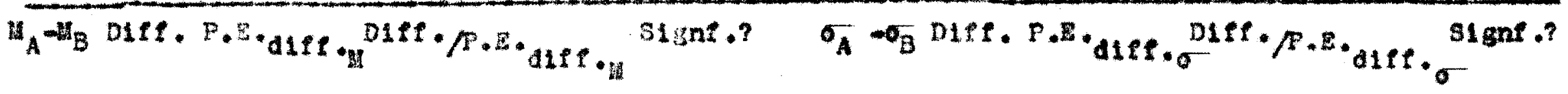

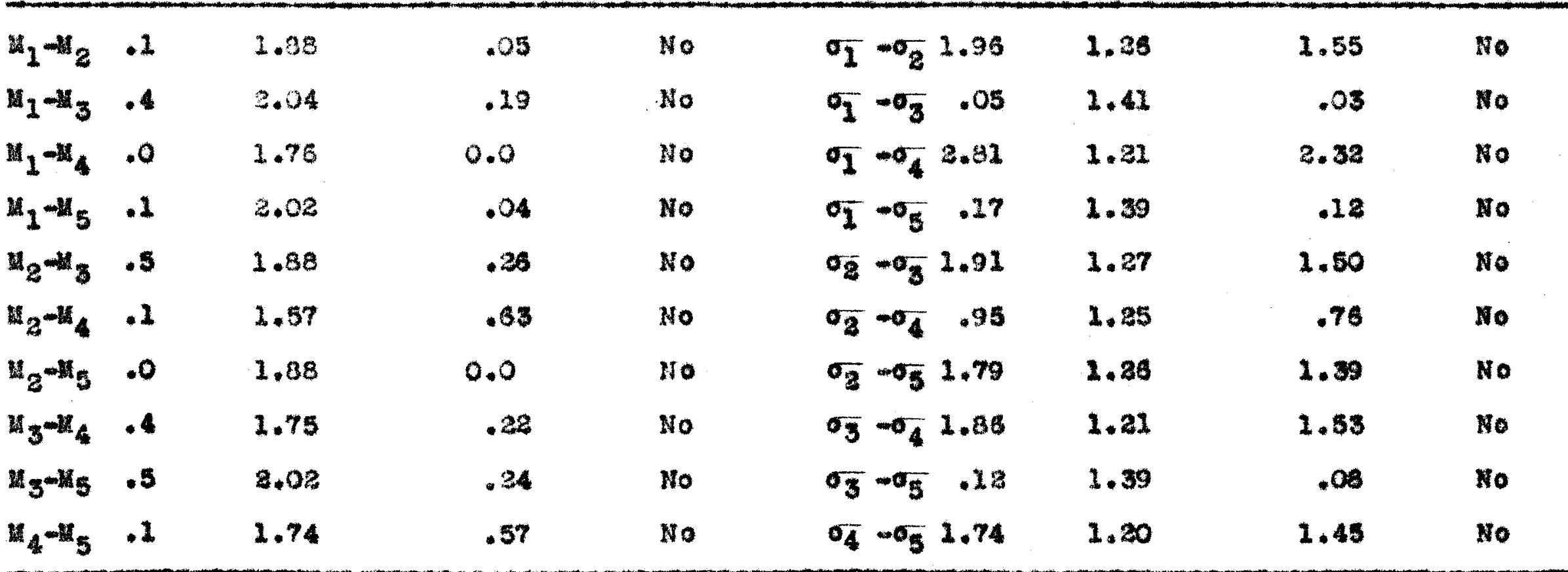

Table LXXIX hows the Iive groups equated on Fending Age to be oquivalent groups, since the differenees between the ans and stand ard deviations are not siznifleant. 


\section{SUHEARY FOR BQUATION OF GROUPS}

In seleoting equivalent groupa, data were secured from 172 al xth-A ohildron in five elementary sohoola. From thase, five groups of twenty-one children each were secured, each child in each group being paired th a child in each of tho other four groups on the basis of sex and obronological age. Thle was called the first, or Chronological Age Group.

For a second group, twanty-one chlldren from each of the five schools were paired on the basis of sex and mental age as measured by the Otis Self-Administering Testa of Hental Abil1tr. ${ }^{9}$ This group was ealled the second, or Hental Age aroup.

A thlrd group was secured by selecting twenty-one childran from each of the five sohools and pairing each chlld In each group with a child in each of the other four groups on the basis of sex and test performance in reading as measured by the Metropolitan Aahlexement Teste. 10

Date for ach of the fivo equivalent groups raking up the Chronologi aal Age Group, the Mental Age Group, and the Reading Age Group, are given In Tables LXXIV, LXXVI, and LXXVIII, pages $188,193,197$.

That the se groups are well equated w1ll be seen from Inspeotion of Tables LXXV, LXXVIII, and LXXIX, pages 190, 194, 198. Here are given the differences between means and varlablllties for the various groups together with the probable orrors of these differences and the resultant quotlents.

9. Otra SelK-Adaintatering Teat of lental Abizity. by Arthar S. Otra. 1928.

10. Hetropolitan Achlerement Tests. Intermediate BatteryPartial: For $A$. For Grades 4,5 , and 6 . Edited by Jacob S, Orleans. 1932. 


\section{B. Teating for Comprehension}

The degree of accuracy with which the selections from oach of the five books were read was determinad as outilned in Chapter III by the tests given in Appendix B for:

I. The groups equated on Chronological Age

II. The groups quated on Mental Age

III. The groups equated on Reading Age

I. Degree of Comprehension with the Grouns Equated for Chronological Age

The basio data for all puplis used in tho fivo groups equated on chronological age are given in rables I. II, III. IV, and $\mathrm{V}$, Appendix $A$.

Group I is the group of sixth-A puplis frose School A, who read the selections and answered the questions of comprehension on Book I. Europe the Hothor of Ameriog, by Horne and Bucks.

aroup II is the group from Sohool B, tested on Book II, Our Nation's Heritage, by Hallook and Frantz.

In like manner III, IV, and $V$ are the eroups from Schools $C, D$, and $E$, tested on Books III. IV, and V, which are The old World Beginnings of Amarloe, by Kelty; the American People and Their Old World Ancestors, by Vollintine, and The Plementary torld History, by Beard and Bagley. The puplls making up the Chronologleal Age Group 
are the 1 rst twenty-one puplis under C.A. Chronelogical Age). These puplls' chronological ages are not preceded by a star. They may be found in the second column of Tables I to $V$. Appendix A, which give the data for the five groups. The soores, or number of correct reaponses are given in the sixth column of these tables under soore. The number of minutes required to read the samplings and anarer the questions on the tests of comprehension is given in the seventh colum under Time.

A sumary of the initial data for each of the group to given in Table VI, VII, VIII, IX, and $X$, Appondix $A$, whieh gives the following data for Age, Soore, and Time.

1. Lean of distribution

2. Range

3. Standard deviation of the distribution

4. Standard arror of the mean

5. Probable error of the mean

6. Standard error of the standard deviation

All of these data are brought together in Table LXXX, page 203. From an inspection of Table LXXX, it will be ween that pupila equated on a basis of sex and chronological age made an soores of: Book I, 57.41; Book II, 56.54; Book III, 62.72; Book IV, 55.67; Book V, 61.0 .

From the mean responses it appears that Book III wh the mean of 62.72 correct answers is easiest to read 
and understand. Book IV with mean seare of 55.67 appears hardest.

Data for evaluating the difference between means and standard deviations are also given in Table LXXX, page 203, for the:

1. Standard deviations

2. Probabla arrora

3. Probable errors of the means

4. Standard errors of the mans

5. Standard errors of the standard deviations

Table LXXXI, page 204, compares the means and standard deviations. An Inspection of this table shows that there are slgnificant differences between the means for Books II and III, Books II and $V$, and Books III and IV.

31 gnlfleant differenoes are found between the standard deviations for Books II and IV, and Books II and V.

The mean comprehensi on with which Book II is read 1s significantly different from that of Books III and $v$, and the comprehension with which Book III is read is significantly different from that of Book IV. 
TABLE LXXXX

DATA FOR THE NUMBER OF CORRECT RESPONSES TO COHPREHENSION QUESTIONS ON THE FIVE BOOKS WHEN TUE PUPILS ARE BQUATED FOR CHRONOLOGICAL AGE.

\section{Comprehenai on Seore}

Book I Book II Book III Book IV Book V

\begin{tabular}{lccccc} 
Mean & 57.41 & 56.54 & 62.72 & 55.67 & 61.00 \\
$\begin{array}{l}\text { Standard } \\
\text { Deviation }\end{array}$ & 9.51 & 4.98 & 7.11 & 9.17 & 8.54 \\
$\begin{array}{l}\text { Probable } \\
\text { Error }\end{array}$ & 6.410 & 3.355 & 4.766 & 6.188 & 5.766 \\
$\begin{array}{l}\text { Probable } \\
\text { Qrror of }\end{array}$ & 1.433 & .745 & 1.061 & 1.382 & 1.283 \\
$\begin{array}{l}\text { Mean } \\
\begin{array}{l}\text { Standard } \\
\text { Brror of }\end{array}\end{array}$ & 2.120 & 1.090 & 1.572 & 2.046 & 1.898 \\
$\begin{array}{l}\text { fean } \\
\text { - }\end{array}$ & & & & & \\
$\begin{array}{l}\text { Standard } \\
\text { Brror of } \\
\text { the }\end{array}$ & & & & & \\
$\begin{array}{l}\text { Standard } \\
\text { Deviation }\end{array}$ & 1.466 & .761 & 1.090 & 1.411 & 1.311 \\
\hline
\end{tabular}

Table LXXX shows that whon the pupils were equated on the basis of chronological age, the questions on Book III were answered with the ilighest number of correct responses, and Book IV the lowest. Book $V$, with a mean response of 61.00 , ranks in aecond place. Book I ranks in third place, and Book II in fourth place.

The data from this table are usad in Table LXXXI where the means and dispersion are compared for signif loance of differenoes. 
TABLE LXXXI

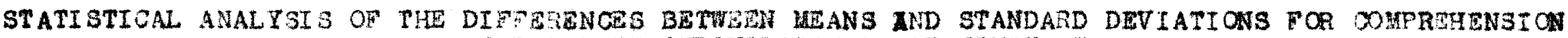
SCORES WITI CHAONOLOGICAL AGR CONSTANT

COMPAAISON OF AVERAGES COMPARISGY OF STANDARD DEVIATIONS

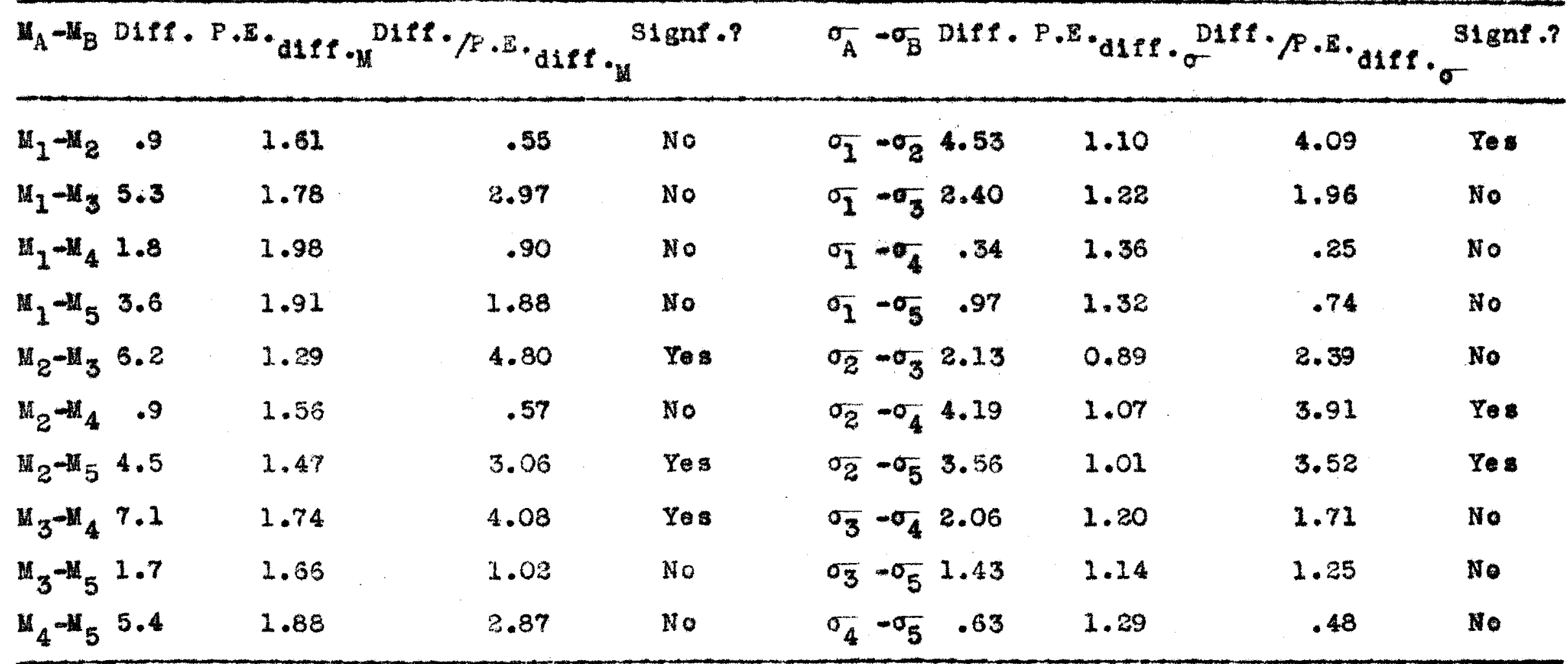

Table LXXXI shows signiflcant differences between the mean for Bocks II and III, Books II and $y$, and Books III and IV.

Signifleant differences are shown between the standard devlations for Books II and IV, and Books II and V. 
T1 ae Required to Read the Selections and Answer the Questions When the Groups Were Equated on Chronologlcal Age

The wean time taken by each group to read the selections and answer the questions on them 1 given in Tables VI to $X$, Appendix A.

The mean time taken by each group is as follows:

$\begin{array}{lll} & & \text { Minutes } \\ \text { Group I tested on Book I } & 30.23 \\ \text { Group II tested on Book II } & 34.23 \\ \text { Group III tested on Book III } & 30.33 \\ \text { Group IV tested on Book IV } & 39.52 \\ \text { Group V tested on Book V } & 25.10\end{array}$

A comparison of means and disperstong for significant differences is given in Table LXXXIII, page 207. An inspection of tisis table shows significant differences between those groups tested on Books I and IV. Books II and V, Books III and IV, and Books IV and V. Significant differences between standard deviations are shown for Books II and IV, and Books III and IV. When the time is compared win the number of correot responses, the pollowing oomparisons are shown. 
HEAN WUMBER OF CORRECT RESFONSES AND MEAN NULBER OF HINUTES REQUIRED TC FINISH THE TESTS FHEN THE GROUPS VERE EQUATED ON CHRONOLOGICAL AGE

Lean Score

\begin{tabular}{lll}
\hline Group I & 57.41 & 30.23 \\
Group II & 56.54 & 34.23 \\
Group III & 62.72 & 30.33 \\
Group IV & 55.07 & 39.52 \\
Group V & 61.00 & 25.10 \\
\hline
\end{tabular}

Mean T1me
Group III, tested on Book III, completed the test wi th the highest score of 62.72 in 30.33 minutas. Group V, tested on Book $V$, completed the test in 25.10 minutes with a sore of 61.00 . While aroup IV, teated on Book IV, made the lorest score of 55.07 and took the longest time, 39.52 minutes.

From this analysis it will be seen that the books read with the greatest accuracy are also read most rapidiy, and vice versa. 
TABLE LXXXIII

STATISTICAL ANALYSIS OF THE DIFFERENCES BETVEZN MEANS AND STANDARD DEVIATIONS FOR TIME SCORES WITH CHRONOLOGTOAL AGE CONSTANT

COMPARISON OF AVERAGES

COMPARISON OF STANDARD DEVIATIONS

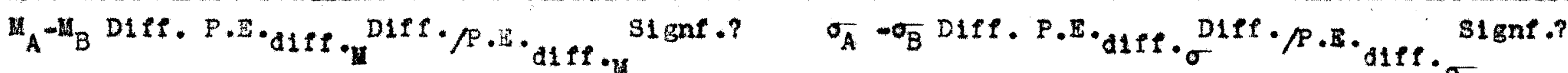

-

\begin{tabular}{|c|c|c|c|c|c|c|c|c|}
\hline$u_{1}-u_{2} 4.00$ & 1.94 & 2.06 & No & $\sigma_{1}-\sigma_{2}$ & .93 & 1.32 & .70 & No \\
\hline$m_{1}-u_{3} \cdot 10$ & 1.92 & .052 & No & $\sigma_{1}-\sigma_{3}$ & 1.09 & 1.31 & .83 & No \\
\hline$u_{1}-u_{4} 9.29$ & 2.64 & 3.51 & Yes & $\sigma_{1}-\sigma_{4}$ & 4.46 & 1.75 & 2.54 & No \\
\hline$u_{1}-u_{5} 5.13$ & 2.05 & 2.50 & No & $\sigma_{1}-\sigma_{5}$ & .13 & 1.40 & .09 & No \\
\hline$u_{2}-u_{3} 3.90$ & 1.82 & 2.14 & No & $\sigma_{2}-\sigma_{3}$ & .16 & 1.25 & 1.28 & No \\
\hline$M_{2}-M_{4} 5.29$ & 2.51 & 2.05 & No & $\sigma_{2}-\sigma_{4}$ & 5.39 & 1.70 & 3.17 & $Y_{e B}$ \\
\hline$u_{2}-u_{5} 9.13$ & 1.95 & 4.68 & $Y e a$ & $\sigma_{2}-\sigma_{5}$ & 1.06 & 1.34 & .79 & No \\
\hline$u_{3}-u_{4} 9.19$ & 2.56 & 3.58 & Yos & $\sigma_{3}-\sigma_{4}$ & 5.55 & 1.70 & 3.26 & Yes \\
\hline$u_{3}-u_{5} 5.23$ & 1.94 & 2.68 & No & $\sigma_{3}-\sigma_{5}$ & 1.32 & $1 \cdot 34$ & .91 & No \\
\hline $\mathrm{H}_{4}-\mathrm{H}_{5} 14.42$ & 8.65 & 5.44 & Yes & $\sigma_{4}-\sigma_{5}$ & 4.34 & 1.76 & 2.46 & No \\
\hline
\end{tabular}

In mean time to read there are significant differences between Books I and IV, Books II and IV, Books III and IV, and Books IV and $V$.

Signifloant differences between standard deviations are shown for Books II and IV, and Booke III and IV. 
II. Degree of Comprohension with the Groups Equated Ior Eental Age

The original data for the pive groups equated on Mental Age are Eiven in Tablas I, II, III, IV, and $V$, Appendix A.

Twenty-one puplis from each of the five groups wero used to make up the five groups equated on sex and mental age. They are the pupils mose H.A. (Hental Age) appears in the the third colum of the above tables not preceded by two stars.

The number of correct responses and the number of minutes taken to read the samples and answer the, questions are given opposite the pupils' numbers in columns six and seven, under score and Time.

Tables XI, XII, XIII, XIV, and XV, AppendiX A, give the statiatical data for the five groups for:

1. Hean

2. Standard deviation of the distribution

3. Probable error of the distribution

4. Probable error of the mean

5. Standard error of the mean

6. Standard error of the standard deviation

Data for this phase of the investigation are presented in Table LXXXIV, p. 220. 
Book I refers to the data for Group I on the questions on Book I. The same interpretation applies to Books II, III, IV, and $V$.

Statistioal analyses are glven in Table LXXXIV for the correct responses to the questions on each of the five books in terms of:

1. Means

2. Standard deviations of the distributions

3. Probable errors of the distributions

4. Probable errors of the ans

5. Standard errors of the reans

6. 3tandard errors of the standard deviation

A comparison of the mean correct responses and standard deviations for the flue books are:

Hean

56.60

55.00

59.60

53.70

60.60
Standard Deriation

Book I

Book II

Book III

Book IV

Book V

$\begin{array}{rr}56.60 & 7.94 \\ 56.00 & 7.60 \\ 59.60 & 9.67 \\ 53.70 & 13.09 \\ 60.60 & 8.39\end{array}$

As judged by their means Book $V$ is slightly easier than Book III, fille Book IV agaln appars hardest.

The slgnifleance of these rean differences is shown in Table LXXXV, page 211 .

Bignificant differences were found between the means of Books II and $V$, and Books IV and $V$ and between the standard deriations of Books IV and V. 
TABLE LXXXIV

STATISTICAL DATA FOR TH NUMEER OF CORRECT RESPONSES TO THE COMPRRHEVSTON QUESTIONS ON THE FIVE BOOKS WHEN THE PUPILS ARE EOUATED FOR TENTAL ACE

\section{Comprehension scores}

Book I Book II Book III Book IV Book V

\begin{tabular}{|c|c|c|c|c|c|}
\hline Lean & 56.60 & 56.00 & 59.60 & 53.70 & 60.60 \\
\hline $\begin{array}{l}\text { Standard } \\
\text { Doviation }\end{array}$ & 7.94 & 7.60 & 9.67 & 13.09 & 8.36 \\
\hline $\begin{array}{l}\text { Probable } \\
\text { Error }\end{array}$ & 5.353 & 5.121 & 6.521 & 9.388 & 5.633 \\
\hline $\begin{array}{l}\text { Probable } \\
\text { Error of } \\
\text { Iean }\end{array}$ & 1.100 & 1.144 & $1 \cdot 454$ & 8.071 & 1.252 \\
\hline $\begin{array}{l}\text { Standard } \\
\text { Error } \\
\text { of tean }\end{array}$ & 1.631 & 1.690 & 2.150 & 3.069 & 1.853 \\
\hline $\begin{array}{l}\text { Standard } \\
\text { Brror of } \\
\text { the } \\
\text { Standard } \\
\text { Devlation }\end{array}$ & 1.222 & 1.171 & 1.491 & 2.050 & 1.291 \\
\hline
\end{tabular}

When the flve groups were equated on the basis of mental age, Book $V$ ras road with somenhat greatar oomprehension than Book III. Book IV was the hardest. Books I and II were very moh alike.

The signifleance of the differences between means and standard deviations $1 \mathrm{~g}$ given in Table LXXXV. 


\section{TABLE LXXXV}

STATISTICAL ANALYSIS THE DI TFPRBNCES BETTEZH MEANS AND STANDARD DEVIATIONS OF SOORES IN COMFREHENSI ON WITH UENTAL AGE CONSTANT

COMPART BON OF AVERAGES

COMPARISON OF STANDAFD DEVIATIONS

\begin{tabular}{|c|c|c|c|c|c|c|c|c|c|}
\hline$u_{1}-u_{2} \cdot 6$ & 1.57 & .38 & No & $\sigma_{1}$ & $-\infty_{2}$ & . 34 & 1.14 & .29 & No \\
\hline$u_{1}-w_{3} 3.0$ & 1.81 & 1.55 & No & $\sigma_{1}$ & $-\sigma_{3}$ & 1.73 & 1.29 & 1.34 & No \\
\hline$M_{1}-H_{4} 2.9$ & 2.36 & 1.55 & No & $\sigma_{1}$ & $-\sigma_{4}$ & 5.15 & 1.76 & 2.92 & No \\
\hline$u_{1}-u_{5} 4.8$ & 1.46 & 2.87 & No & $\sigma_{1}$ & $-\sigma_{5}$ & 1.54 & 1.05 & 1.46 & No \\
\hline $\mathrm{M}_{2}-\mathrm{M}_{3} 3.6$ & 1.84 & 1.95 & No & $\sigma_{2}$ & $-\sigma_{3}$ & 2.07 & 1.27 & 1.62 & No \\
\hline $\mathrm{H}_{2}-\mathrm{H}_{4} 2.3$ & 2.75 & .83 & No & $\sigma_{2}$ & $-\sigma_{4}$ & 5.49 & 2.26 & 2.40 & No \\
\hline$M_{z^{-H_{5}}} 4.8$ & 1.48 & 3.24 & Yes & $\sigma_{\overline{2}}$ & $-\sigma_{5}$ & 1.20 & 1.02 & 1.17 & No \\
\hline$M_{3}-w_{4} 5.9$ & 2.52 & 2.34 & No & $\sigma_{3}$ & $-\sigma_{4}$ & 3.42 & 1.70 & 2.01 & No \\
\hline$M_{3-M_{5}} 1.2$ & 1.73 & .69 & No & $\sigma_{3}$ & $-\sigma_{5}$ & 3.27 & 1.20 & 2.72 & No \\
\hline$M_{4}-u_{5} 7.1$ & 2.28 & 3.11 & $\mathrm{Yea}$ & $\sigma_{4}$ & $-\sigma_{5}$ & 6.69 & 1.53 & 4.37 & Yes \\
\hline
\end{tabular}

Table LXXXV shows signifleant differences between the ans for Books II and $V$, and Books IV and $V$, Books I and II appear mach alike.

The standard deviations of Books IV and Book $V$ are signifloantly different. 
1. Tlme Bequired to Read the Selection and Answer the ouestions When the Croups Fere Equated on Mental ARe

The mean number of minutes taken by ach group to read the selections and answer the tests of comprehension on them Is ziren in Tables XI to XV, Appendix A.

The time taken by ach group to complete the testa is as Pollows:

$\begin{array}{lll}\text { Group I } & \text { tested on Book I } & \frac{\text { Minutes }}{33.04} \\ \text { Group II } & \text { tested on Book II } & 35.90 \\ \text { Group III } & \text { tested on Book III } & 32.66 \\ \text { Group IV } & \text { tested on Book IV } & 42.00 \\ \text { Group V } & \text { tested on Book V } & 28.15\end{array}$

A comparison of means and dispersions for signifloant differences is given in Table LXXXVII, page 214.

Significant differences are shown between the groups tested on Books I and IV, Books II and V, Books III and IV, and Books IV and $v$.

Differences between dispersions are show for those groups tested on Books I and IV, Books II and IV, Books III and IV, and Books IV and V.

When the mean number of correct responses is compared wi th the mean number of minutes taken to complete the tests there appears to be little consistency. 
TABLE LXXXVI

MEAN NUUBER OF CORRACT RESPONSES AND MEAN NUUBER OF HINUTES REQUIRED TO FINISH THE TESTS WHEN THE GROUPS HERE BQUATED ON UENTAL AGL

$\begin{array}{lll}\text { Group I } & 56.60 & 33.04 \\ \text { Group II } & 56.00 & 35.90 \\ \text { Group III } & 59.60 & 32.66 \\ \text { Group IV } & 53.70 & 42.00 \\ \text { Group V } & 60.80 & 28.15\end{array}$

Group $V$, tested on Book $V$, made the highest man soore of 60.80 in the shortest mean tims of 28.15 mimutes. Group III dropped to.second place with a mean acore of 59.60 In 32.66 minutes. Group IV continued to have the 10west mean score of 53.70 in the longest mean time of 42.00 minutes. Book II contlnued in fourth place. 
TABLE LXXXVII

STATISTICAL ANALYSIS OF THR DIFTERENGES BETUEEN UEANS AND STANDARD DEVIATIONS FOR TIUE TO COAPLETE THE TESTS TITH TENTAL AGE CONSTANT

COMPARISON OF AYERAGES

COMPARISON OF STANDARD DEVIATIONS

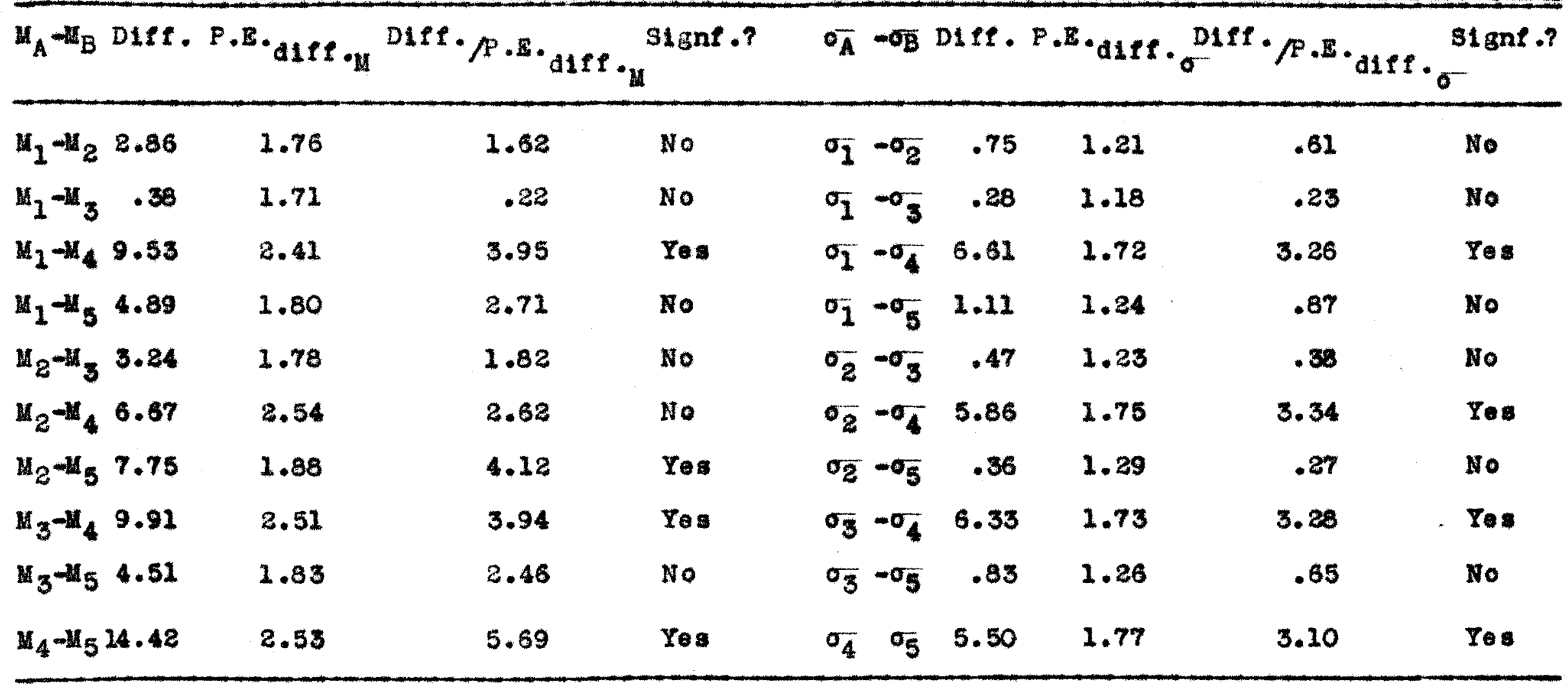

Table LXXXVIT shows signifleant differences between the means $f$ or Books I and IV, Books II and $V$, Books III and IV, and Books IV and $V$.

Slgniflcant differences were found tween the standard deviations for Books I and IV, Books II and IV, Books III and IV, and Books IV and V. 
III. Degree of Comprehension When the Groups The Equated on heading ARe

Onder R.A. (Reading Age) in the fifth oolumns of Tables I, II, III, IV, and V, Appendix A are given the reading ages of the twenty-one chlldren from each group making up the group equated on Reading Age.

The reading ages used for these equivalent groups are those not preceded by three stars.

In the two columns lmadiately to the right of R.A. are the numbers of correct responses and time used to complete tho tests.

Tables XVI, XVII, XVIII, XIX, and XX, Appendi X A, give the data for each of the groups for the Mental Age, seore and Time.

The se data are sumarized in Table LXXXVIII, page 217, where the responses of each group are shown under each Book. A mean of 58.20, under Book I, moans that Group I answered the questions on the seleotions from Book I with an average of 58.20 correct responses.

Following are the ans for the five books: Book I, 58.20; Book II, 56.0; Book III, 60.50; Book IV, 56.60; Book v, 60.60 .

The number of correot responses for Book V is .10 greater than for Book III. Books II and IV differ by .60 , and Books III and IV differ by 3.90 correct responses. 
An Inspection of Table XC, page 2l9, however, showe that none of the differences between the means are signif1cant.

Standard daviations of scores for the five books are as follows: Book I, 8.08. Book II, 7.75; Book III, 9.00; Book IV, 8.02; Book V, 8.38.

Comparison of the standard deviations is given in Table XC. None of the differences between standard deviations are significant.

When the groups are quated for sex and reading age as show by performance on the Metropolitan Achlevement Teste slight differences appear in the degree of accuracy w1 th which the books are read. Book II appears to be slightly the hardest, and Book $V$ very slightly the easiest. These differences, however, are not statistically signiflcant. (Table XC, page 219).

1. Time Required to Read the Geleations and Answer the questions when the Groups Were Equated on Boading age

The mean number of minutes taken by each group to read the selections and answer the oomprehensi on questions on the $1 \mathrm{~s}$ given in Tables XVI to XX, Appendix A. 
Tho mean number of minutes required by each group to complete the tests is given below:

\section{Yinutes}

Group I tested on Book I

Group II tested on Book II

tested on Book III

tested on Book IV

tested on Book V
31.85

34.00

35.00

42.14

25.67

Analysis of differences botween means and standard deviations is given in Table XCI, page 220.

Differences between the means $f$ or the group tested on Books I and IV, Books II and $V$, Books III and $V$, and Books IV and $V$ are signifloant.

No signifleant differences ware $f$ ound between the measures of dispersions for these groups.

The mean number of correct responses and the mean number of minutes required to complete the tosts are given in Table LXXXVIII.

\section{TABLE LXXXVIII}

MEAN NUMBER OF CORRECT RESPONSES AND MEAN NUIE ER OF MINUTES REQUIRED TO FINISH TEE TESTS WHBN THI GROUPS FERB EQUATED ON MENTAL AGE

Mean Soore

Group I

Group II

Group III

Group IV

Group V
58.20

56.00

60.50

56.60

60.60
Lean Slat

31.85

34.00

35.00

42.00

25.67 
TABLE LXXXIX

STATISTICAL DATA FOR THE NUUBER OF CORRECT RESPONSES TO THE COUPREHENSION QUESTIONS ON TIE FIVE BOOKS WTEN THE PUPILS ARE EQUATED FOR READING AGE

\section{Comprehensi on Scores}

Book I Book II Book III Book IV Book V

Hean

$58.20 \quad 56.00$

60.50

56.60

60.60

Standard

Deviation

$$
8.08 \quad 7.75
$$

9.00

8.02

8.36

Frobable

Error

$5.455 \quad 5.222$

6.072

5.400

5.633

Probable

Error of

Mean

$1.211 \quad 1.161$

1.356

1.200

1.252

Standard

Error

of Hean

$1.266 \quad 1.720$

2.002

1.779

1.853

Standard

Error

of the

Standard

Deviation

$1.794 \quad 1.191$

1.380

1.235

1.291

Then the five groups were quated on the basis of reading age, Book $V$ was the easiest. Book $V$, however, is only .10 response higher than Book III. Book IV showed th lowat number of correct responses. Book I ranked third and Book II fourth.

Significance of differences between means and standard derlations is analyzed in Table XC. 
TABLE XC

STATISTICAL ANALYSIS OF THE DIFTERENCES BETWEEN GEANS AND STANDARD DEVIATIONS OF SCORES IN COMPREHENSION WI TH READING AGE CONSTANT

COUPARISON OP AVERAOES

COUPARISON OF STANDARD DEVIATIONS

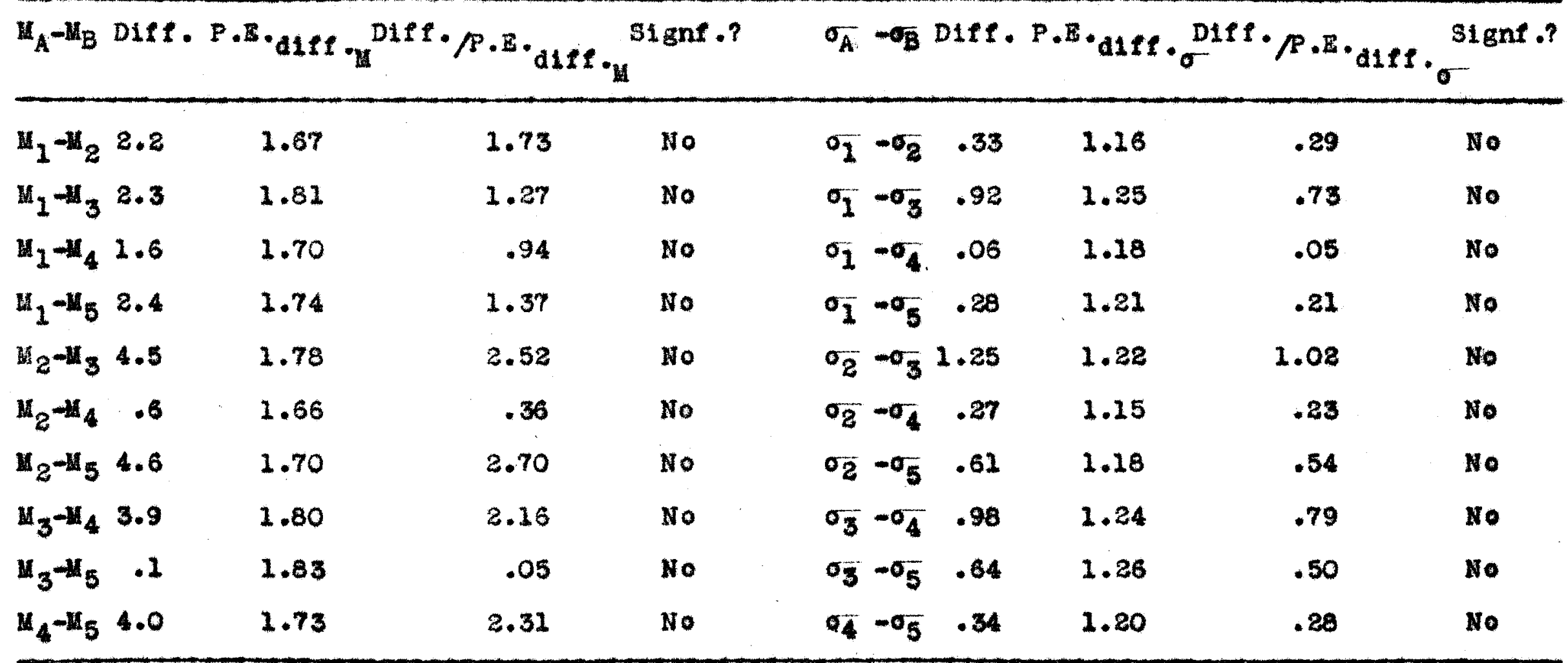

Table XC showe that there are no aignificant differences between the mans nor the standard deviations when the groups are quated on reading age. 
TABLE XCI

STATISTICAL ANALYSIS OF THE DIFT ZRENCES BETWEEN MRANS AND STANDARD DEVIATIONS FCR TIME TO GOMPLETE THE TESTS WITH READING AGE CONSTANT

COUPARISON OF AVERAGES

COMPARISON OF STANDARD DEVIATIONS

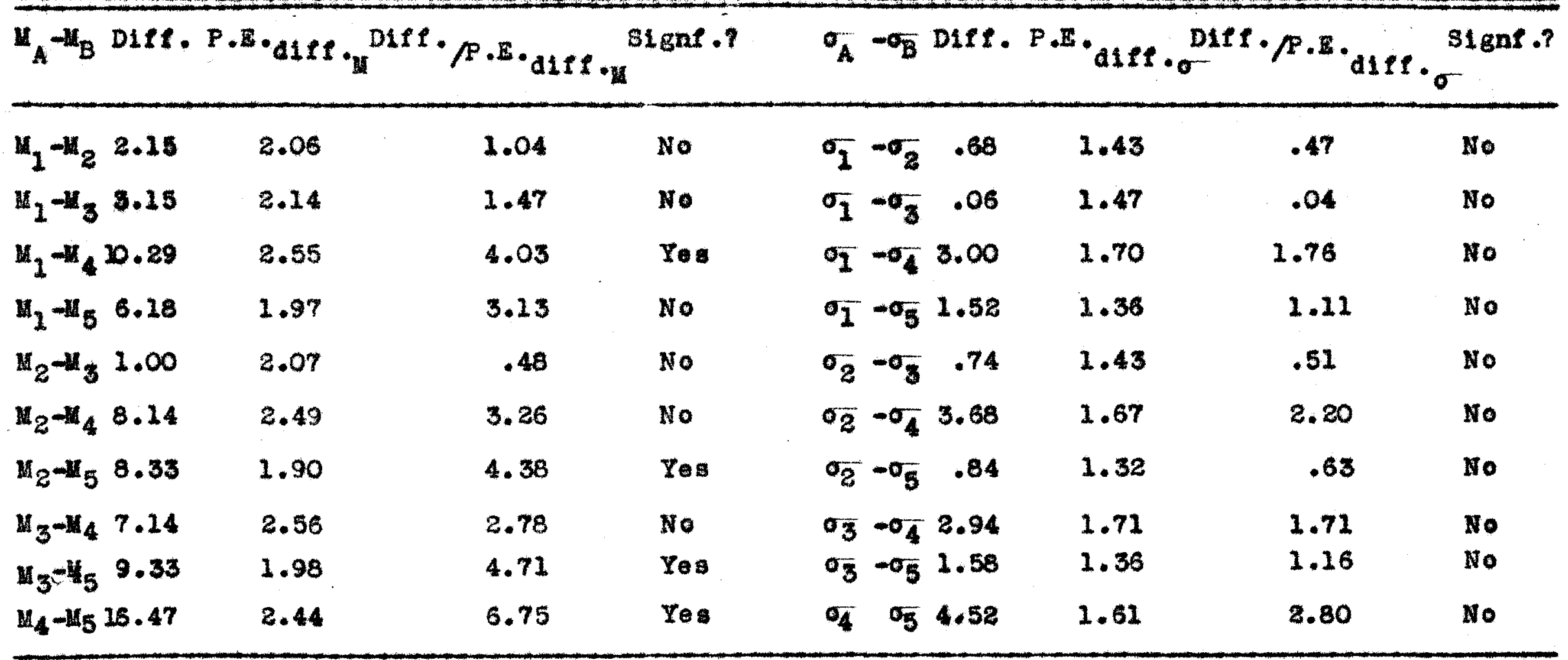

Table XCI show algnifloant differences between the means for Book I and Book IV, Book II and Book V, Book III and Book V, and Book IV and Book V.

There are no signifioant differences between any of the standard deviations. 
Group V, reading Book $V$, had the highest score $(60.60)$ In the shortest tine ( 25.67 minutes). The group reading Book III was second in comprehenatbility but required more tit than the Eroup reading Book I or Book II. The group reading Book IV required the longest the but their mean seore was sightly higher than those readind Book II. This diferenoe in score is not signiflcant. (Table LXXXIX, page 218)

Ranklngs of the books on the degree of comprehenat on w th whlch they wore read by the groups equated on the three Vartabies are given in Table XGI:

TABLE XCII

BOOKS RANKED AS TO MEAN PLRFORMANCE ON THE COUPREHENSION TESTS WHEN THE GROUPS WERE RQUATED FOR CIRONOLOGICAL AGE, MENTAL AGE, AHD READTHG AGE

\begin{tabular}{lccccc}
\hline & Book I & Book II & Book III & Book IV Book V \\
\hline $\begin{array}{l}\text { Chronological } \\
\text { Age }\end{array}$ & 3 & 4 & 1 & 5 & 2 \\
ILental Age & 3 & 4 & 2 & 5 & 1 \\
Reading Age & 3 & 5 & 2 & 4 & 1 \\
Ararage & 3 & $41 / 3$ & $12 / 3$ & $42 / 3$ & $12 / 3$ \\
\hline
\end{tabular}

Book I is third in comprebension by the pupils equated for each of the three varlables. Book II is fourth $f$ or chronological age and mental age-groups, but fifth for the reading a ge groups. Book IV is most difficult for the groups when -quated for chronological age and montal age, bat falls to fourth place for reading age group. Book $V$ how a slightly higher rank than Book III. In averaged order of comprehensibility, from a easiest to most alfficult, they are: 
Book V, Book III, Book I, Book II and Book IV. There are no signillcant diffarences, however, between Book $V$ and III as shown by the statistical analysis of the means when equated for ohronological age, mental age, or reading age.

Table XCIII below gives a comparison of the mans of the books wen the groups were equated for the three bases and hows where signiflcant differences occurod as neasurod by statistical analysis.

\section{TABLS XCIII}

STOATPICANT DTEF TIIS GROUPS AND READTNG AGE

Chronological Age

Books II and III

Books II and $V$

Books III and IV
Mental Age

II and $v$ IV and $V$
Reading Age

No significant difference

The location of signiflcant differences betreen means for the six analyses made of the flve books are given below. The numbers of the books are given opposite the analyses as, I 3 II for Books I and II, etc.:

1. Per cent of words beyond 6047 III and IV

2. Words to the santence I IV. II IV, III IV, IV \& $v$

3. Sentenoes to the paragraph None

4. Fords to the phrase I \& IV, II \& IV, III \& IV, III \& V

5. Phrases to the paragraph I \& III, II \& III

6. Phrases to the sentence

II $\&$ III, II IV, III \& IV, IV \& V, I \& III, I \& IV. 
Book I is not signifieantiy different from the othor booke In the degres of acouraog with which the pupll. comprehended it. It ia, however, algalfleantly differont Irom Book IV when analyzed for: Humber of words to the santence; Mamber of words to the phrase; and Number of phraese to the entanee.

Book II is algnifteantly different from Book III in the degree of accuracy of couprehension when the groups are oquated $t$ or ohronologion age. It is also algnifloantly different fron Book $V$ when the groups are equated for montal age.

Book II Is algnificantly different from Book IV on number of words to tho sentence and number of mords to the phrase. It is algnif leanthy different fron Book III on the number of phrases to the paragraph and number of phrases to the sentence.

Book III, Is significantiy different trom Book II on oomprehension when the zroups are quated for chronologleal age: also from Book IV on number of words to the sentenoe. and number of words to the phrase. It is algniflcantly different from Boois $v$ on number of mords to the phrase. Book IV wilcis is algnificantly different from Book III on comprehenel on then the groups are equated for chronological ago, differs signiflantly fron Book $v$ whon the groups are equated $f$ or montal age. Book If is aleo 


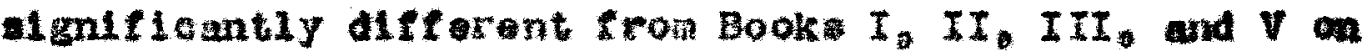

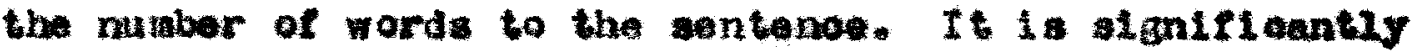
different from Dooks I. II, and III on tha number of rorde to the phrase, and Bookg I, II, III and $V_{0}$ on the number of phraa to the sentenes.

Book $V$ which $1 \mathrm{~s}$ gateloanbly differant frow Book IV

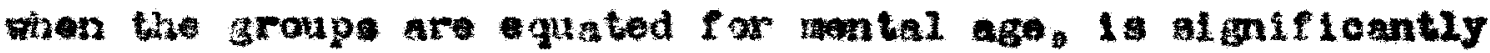
difterent from Book IV when analyzed for numbr of words to the santence: from Book III for the mabar of words to the phrase: and fron Boof IV for the muber of phrases to the sentenoe. 
SUMMARY OF ANALYSIS OF DEGRER OF COMPREHENSION WI TII VHICH THE SELECTI ONS WERE READ

1. Analysis of the data show that there is no stgntslcant differenee wh thich the puplls comprehended the books, as represented by their samplings, when the group are equated on the basis of sex and reading ago.

2. There is a signifleant diffarence between the comprehension soores on Books II and III, Books II and $V$, and Books III and IV when the group are equated for ohrono$\log 1$ cal ago.

3. There is a signiflaant difference between the comprehensi on scores on Books II and $V$, and Books IV and $V$ when the groups are equated for mental age.

4. Significant differences between comprehension scores of groups equated for chronological age were found between books whioh differed significantly in:

1. Number of rords to the sentenos

2. Number of words to the phrase

3. Number of phrages to the sentence

5. Significant differences between comprehension scores of group equated for mental age were found between book which differed significantly in:

1. Number of words to the sentence

2. Number of phrases to the sentence

6. Long involved sentences, wh the large number of phrases to the sentenoe, and to the paragraph, appear to bear some relationship to the amount a child learns from a book. 
The number of sentences to the paragraph, however, is not statistically signifloant.

7. The number of words to the sentence appears to have some bearing on the amount a child comprehends from a book, signifloant differences belng found between the oomprehension of Books III and IV and Books $V$ and IV.

8. The number of words to the phrase has a slight relation to the number of correot responses made by the children; significant differonoes belng found between Books III and IV.

9. For the number of plurases to the sentence, slgnif1oant differences were found in the amount comprehended from Books III and IV and Books V and IV.

10. Book IV whoi hes the hardest vocabulary, the longest sentences, the Iongest phrases, and the greatest number of phrages to the sentence, is road with the lowest degree of comprehensi on by the groups quated for chronological age and mental age, and is only 0.60 pointe higher than Book II when the groups are equated for reading age. 11. Book III, which appears easiest when ranked for rocabulary, plarase-length and number of sentences to the paragraph, ranked highest on the number of correct responses by the groupe quated on ohronological age, and next to highest by the groups equated on mental age and reading age. There are no algniflcant differenees, however, between the number of correct answers made on Book III and Book $V$. 
12. Book $V$, which was slightly the easlest for the group equated on mental age and reading age, is third or fourth in ease of vocabulary, phrase-and sentence-length and number of phrases to the sentence and to the paragraph. 13. Book I, which is the easiest in terms of sentence-length, phrases to the sentence, and phrases to the paragraph, is thi rd in ease of comprehension for the groups equated on chronological age, mental age and reading age.

14. The fire books are moh allke. Factors other than vocabulary, phrase-and senteneo-length, and length of paragraph, appear responsible for small differenees in the degree of comprehensi on with which the equated group read the representative selections from them. 


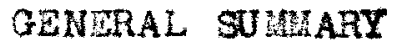


This study is an attempt to detarmine in terms of comprehonalbility the requirement for a history text at the sixth-A level as outlined in educational and psyohological Iitorature and to ascertain how well live supplementary history books assigned to that grade in the Loulavilie Public Schools meet the requirements.

The investigations, as giten under "Literature" in Chapter II, find that satisfactory comprohension of a textbook is dependent apon:

1. The vocabulary in which the book is written

2. The length of sentence and clearness of its structure

3. The nature of materials used

4. The purpose of the reader

5. The method of attaoking the problea

Most writers are in agreenent that vocabulary is a very strong factor in determining the amount a child learno from a textbook, and that a book mat be made up of words that are known to be in the rocabulary of the pupils using the book.

The fact is pointed out, moreover, that words have many shades of meaning and it is a great orror to asmo that the meaning of a word understood in one situation is understood in another. 
Dewey finds that werely the fact that a word occurs in a Fe11-known vocabulary 11 st 1 no guarante that its meaning will be known by children. The investigations rade by Nolte showed no si iniflcant difference between comprahenai on of selections read in the orlginal form and those with simplified rocabularies.

This is contrary to the Inding of Pressey. Johnson. Cutriglu, Ayer, and vesley, whose investzgation showed that comprehension depends to a marked extent upon vocabulary range, technilcal meaning of words, and frequency of usage. These writers are not agreed as to the number of unknown words chlid may noounter and still read wi th understanding, their opinlone ranging from one word to 50 per cent, nor aro they in full agreement with Uhl, Horn, and Gates; but all agreo that if these unianillar worda are key words, their number must be very small or an adequate interpretation of the selection is lmposible.

That comprehenai on is influeneed by sentense-length and sentence-structure is pointed out by Gates. Ayor, Buroh, Gray and horn. Ayer found that long-1nvolred sentences retarded comprehension and that simplification of sentencestructure ralsed the degree of comprehension two gradea. Iorn and Gray found that sentence-structure inf luenced conprohension to a great extent, whilo Burch $t$ ound that both length of sentence and length of paragraph influenced the amount of a chlld*a comprehension. Smoek, however, found 
no signiflcant difference in comprehension when puplis were tested on original and shortened sentences.

Abstract toplas such as "Ilnanoe," "political partien," and "tarlep" are difficult to comprehend regardless of sentence-structure, as are materials dealing with timo, plaoe, maps, and graphs.

That the degree of comprehension on these and other materials as well as speed of comprehension is influenced by the interest and purpose of the reader was found by invegtigations of Gray and Gates.

The degree of comprehension is further dependent upon the method employed by the pupil. Some read selection and attempt to get the thought as a mole. Uany, however, as found by Dewey, Ayer, and Fosley, make no attampt to get the moaning as a wole, but attempt to find exact words or sentences containing the answer to the question sought, and failine in this, resort to verballsm. Such pupils comprehond very little of what they read as shown by Nolte's interviews and pieture testa.

The degrea of comprehension, however, is a problem of grave concern to investigators who find that children respond to test materials taken from their textbooks with a comprehension of only 25 to 50 per cent of the content, and in some cases this drops as low as 8 per cent. Ayer states that the commonly accepted degree of comprehension mist not be below 75 per cent accuracy, while 
Burch finds that to justify the expenditure of time upon materials, the degree of accuracy must be 75.25 per cent or midway between 59.40 and 89.85 per cent.

From these investigations the writer accepted rocabulary and sentenoe-leng th-and-structure as important factors in determining the satisfactoriness of history supplementary books. The findings of Burch and Ayer were accepted, setting an acceptable degres of comprehension at 75 per cent accuracy.

There is no clearly established boundary for vocabulary, but sinee it is generally agreed that the rocabulary in which materials of instruction are written mat lie within the understanding and coman usaige of the pupils, the miter has used the average number of words known by children of a given age, as determined by Terman, and placed this on the Thorndike Frequency of Usaze Scale at 6047, with an arbitrary degree of comprehension of 97 per oent as a standard.

From ach of five supplenentary history books assigned to the sixth-A Grade, the writer and Pive other teachera selected seventeen paragraphs as being representative of the books as wholes. These were analyzed for vocabulary range according to Thorndike's Frequency of Usage Scale, and sentence- and phrase-length, and checked on representativeness by comparing the odd-numbered paragraphs and the even-numbered paragraphs. 
If 97 por cent of tho vocabulary of a book was wthin tho 6047 lavel on the Thomdike Soalo, tho book was consldered as sultablo $f$ or the sixth-A 8 rade in so far an 1 to rooabulary was conoarnad.

Tests of comprohenstion ware nade $f$ or ach of the books. These wel usod to detemine how accurately five oquated groups of alxth-i pupila read the ropreantativo sapplinge. The groups woro aquated in torea vays: vith sex and onronologlcal age hold oonstant, th arex and nontal age constat, and wit sex and reading age constant. The avoraje randins age of chidoron in this grade Was 12 Jears and 5 months on tho Matrogolitwa Achlovement Toste. If pupis of this reading (12-5) age oomprohended 75 per cent or mare of the teat materiala of a boak. tho book nas considarad of suitable comprehansiblizty for that reading-age laral.

It was Found that Book III tas the only one of the

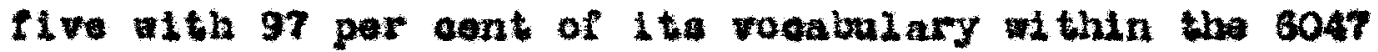

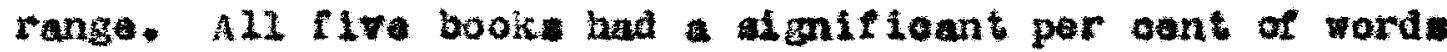
beyond the 5047 leval. Only ono difforenou of statiation Agnificance was fund betweon the books, howavar. hat botmen Books III and IV.

Al1 of the books were read with a degroe of acouraoy above 75 per cent by pupl1s tho sored a raading azo of 12-5 on the Ietronolitan Achionement tegta. In averaged order of comprehengibility. from oastest to most diffloult. 
the books are: Book V. Book III, Book I, Book II, and Book IV.

Fhen chronological age tas be 10 congtant significant diffarences in degrce of comprehenstion ware found betwean books that differod signiflcanty in: I. For cent of worde beyond the 6047 level (III and IV): 2. Hean phrase- and sentence-length (III and IV); 3. Number of phrages to the sentence (III and IV, and II and III): 4. Tumber of phrages to the paragrapla (II and III).

*o signifleant difference wore found in degree of comprehension th thl ch the pive books rere read when the groups were equated on reading aze.

when tha groups were oquated for mental age, slgnlfloant differences in degree of conprehensi on were found only between books that difforcd atenifleantly in: 1 . Tord to the sentence and phrases to the sentenoe (IV and V).

Bcote IV, Ehich has the hardest roeabulary, tho longest pentences, the longest phrases, and the greatest number of phrasae to be sentence, was read of the lowast degres of comprehenaion with chronologieal ago oonstant and th nental. age oonstant, and was only 0.50 polnts higher than Book. II with reading age constant.

As far ss this study is eoncerned there are very dofinite standards tow in the eduoational and poyehologlcal literature for history books at the stxth-A grade level. assuming that unanisty of opinion as a satactory 
criterion for the determination of atanderd. Analysis of the five history books assigned to this level in the Lonisville Public Schools reveals an umsual degree of conformity to these standards, all of the books boing well within the range of comprehenalbility usually considered essential. It $w 111$ be noted, however, that some of the books are markedly aperior to others in certain features and that, in torm of the accopted standards, some of the books show distinct weaknesses. While the authors of these books have considered educational requirements remarkably well it is evident that they oould do even better than they have by more careful regard to vocabulary, particularly to multiplo usage of vocabulary terms, and to sentence, phrase, and paragraph construetion. That more rigid requirements are to be expected in the future by those responstble for textbook selections at this grade level is a reasonable expectation in viow of the positiveness with which the se requirements are set down in the il terature. 
APPENDIX A 


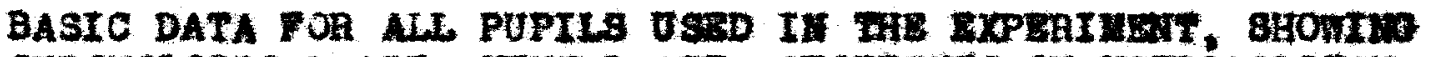

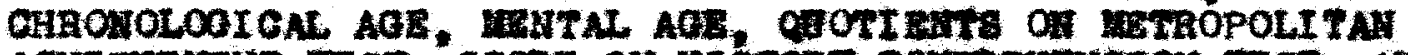
MorI

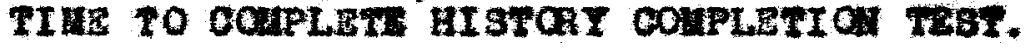

\section{GROT $\mathbf{I}^{1}$}

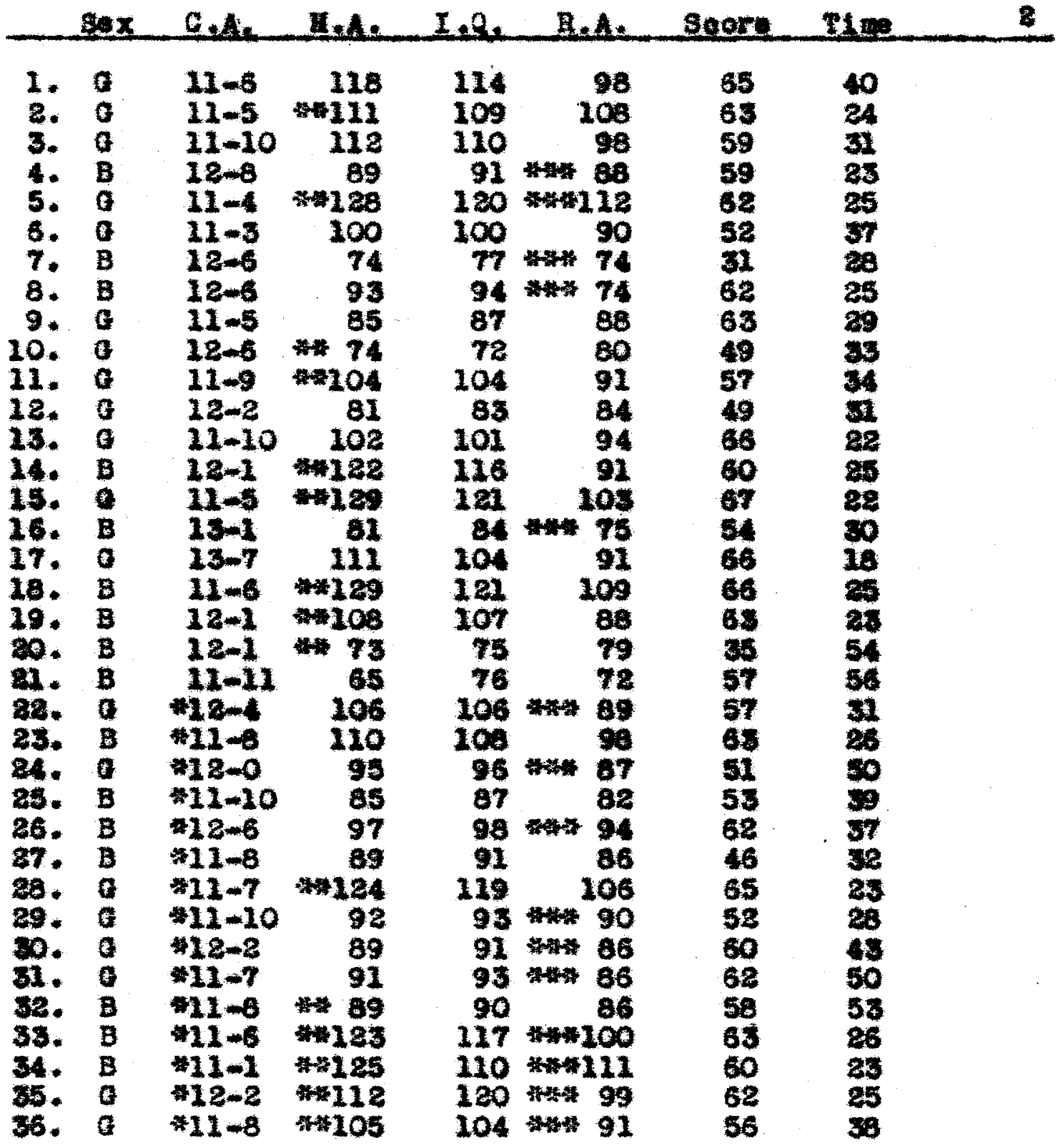

F Paplin not uned in the groupe equeted for chronelogien age.

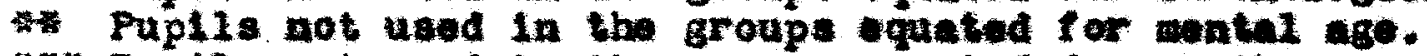

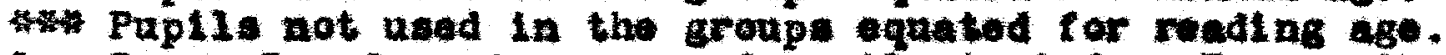
1. Group I Fefere to group of paplis tanted an Jurone the

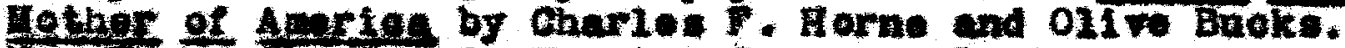

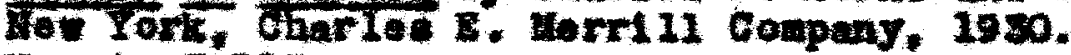

2. Hey to TABH

Sax, o clxty B boy

C.A.; Ghronologleal Ago

Y.A. Hental Ago quotient

I.Q. Intelligenee quetient

A.A.: Reading Age quotient
TLE, TLa In atnutes to complete the HIotory Comprehanat on Teos 


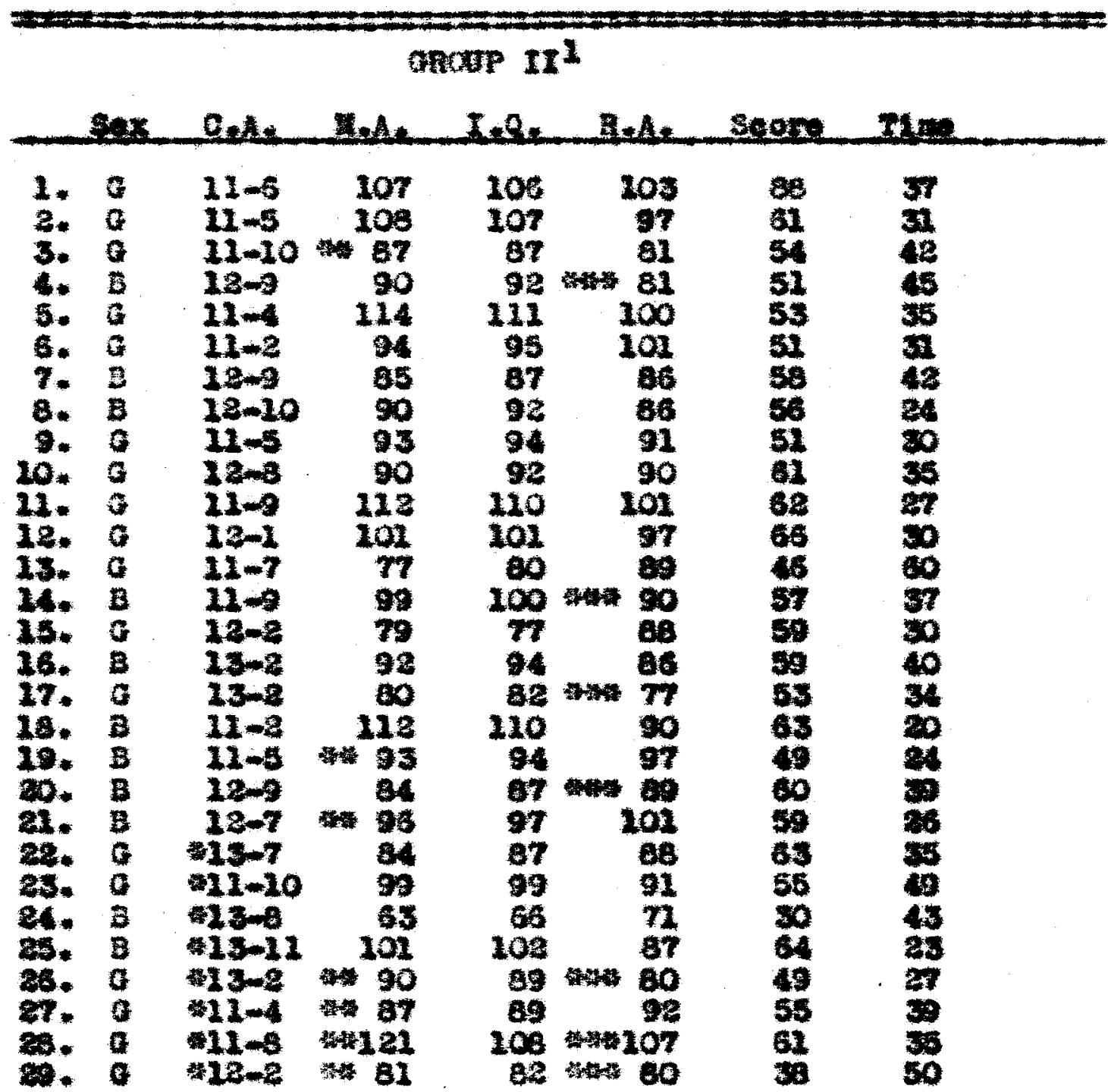

2. Group II refore to group of puptis tedted on gar

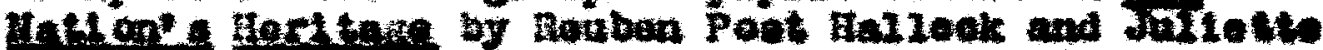

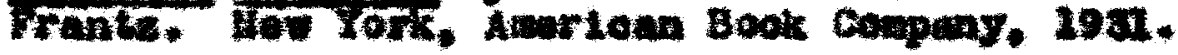




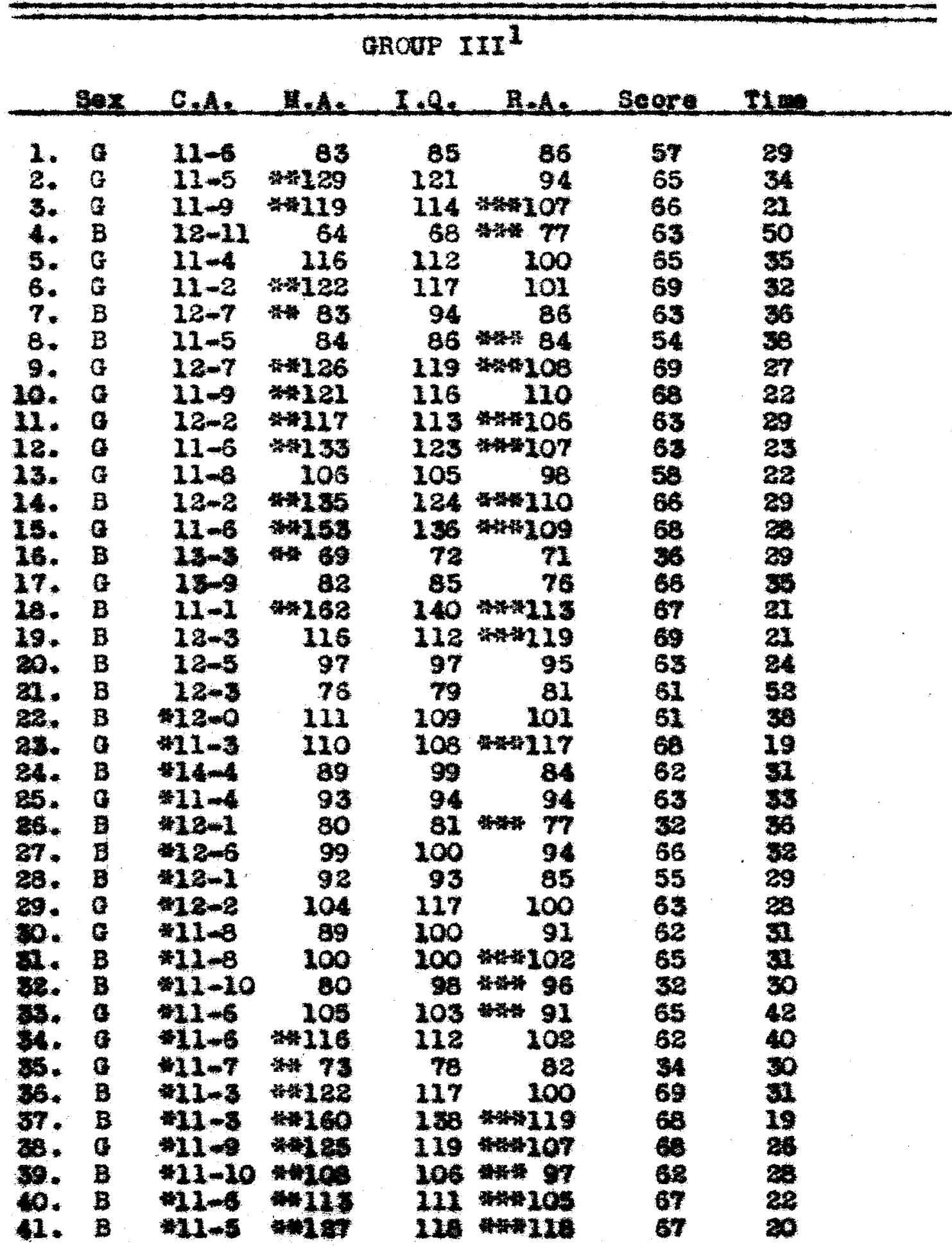

1. Group III refor: to aroup of puplis tested on the

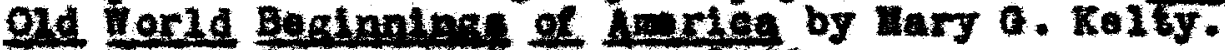
Iow Tork, otma and boipany, 1958. 


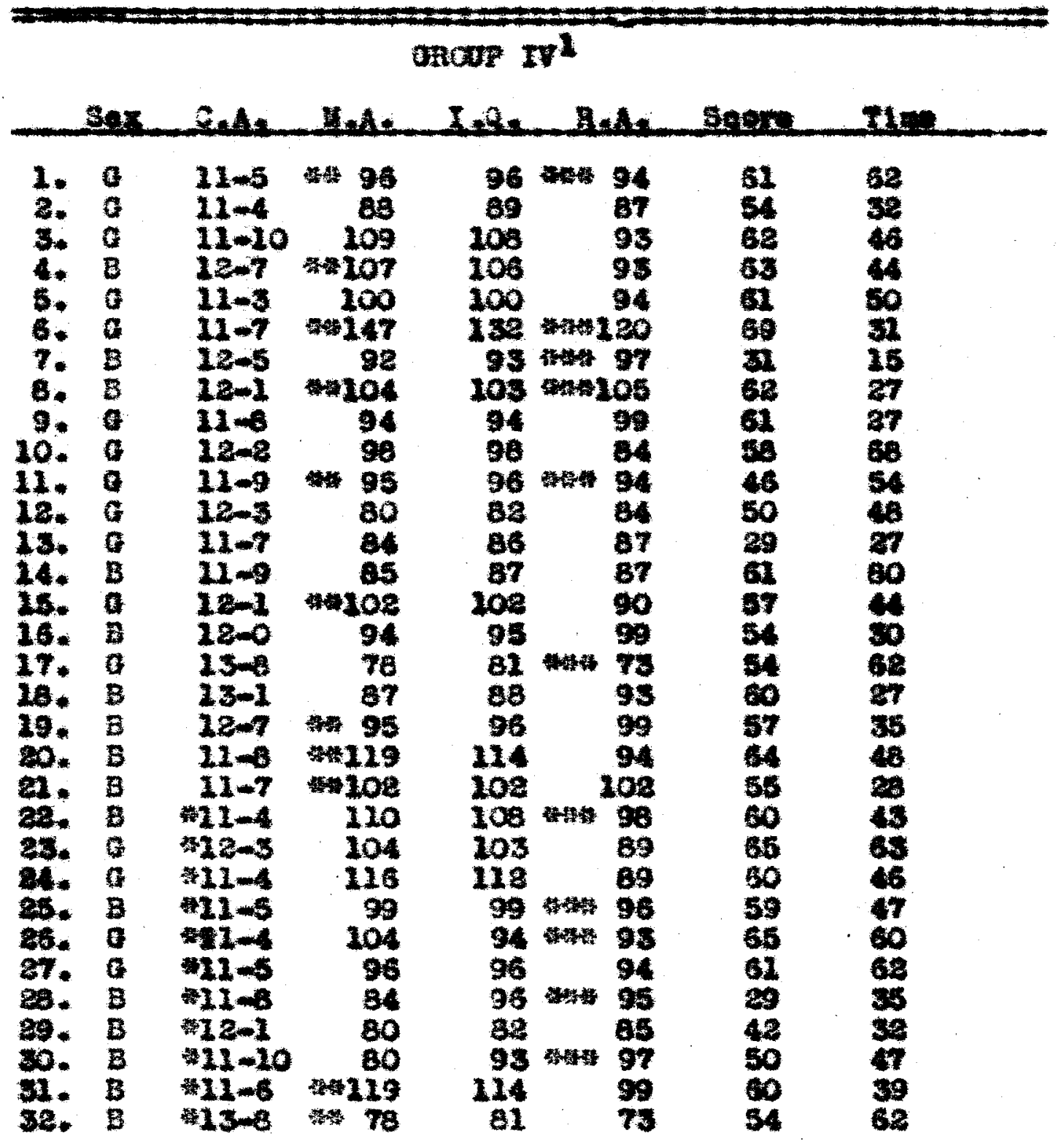

1. Group IV rafore to oroup of puplle tested on tha

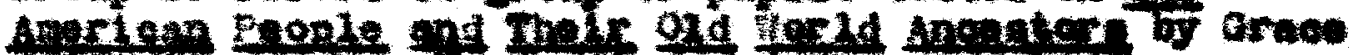
Voxinxine. Ho Xork, arm end compan, 25E. 
TABLE

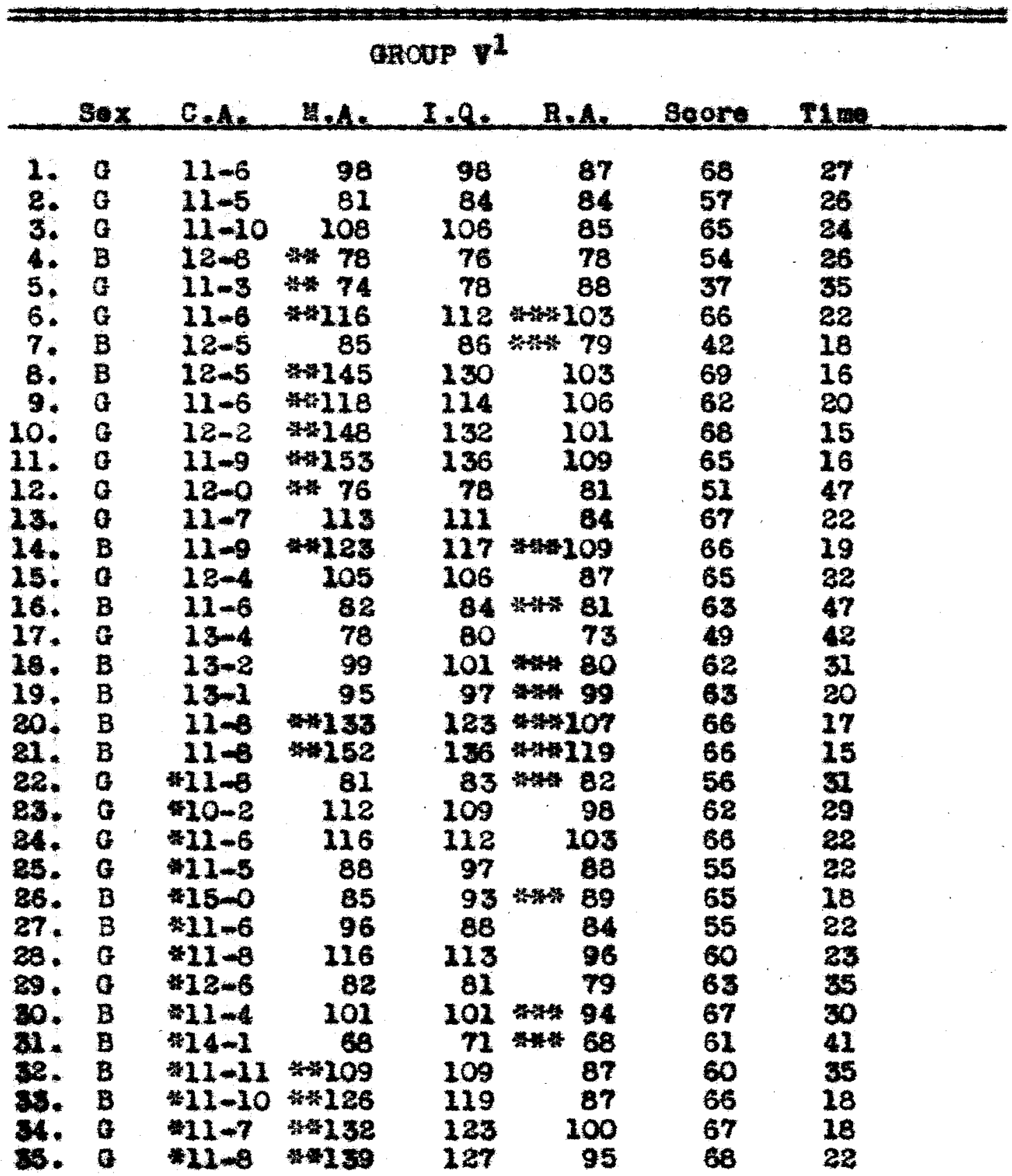

1. Oroup refor: to group or papil soted on the Elementart porld Hictort by plilian c. Bagley. fow York, The hedillan coupany, 1988. 


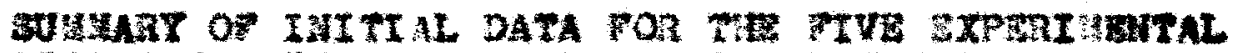

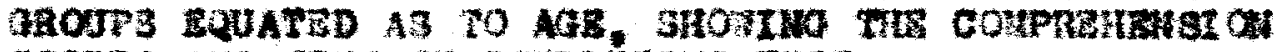
SCORES AWD Trut O COAPLETIN Tas.

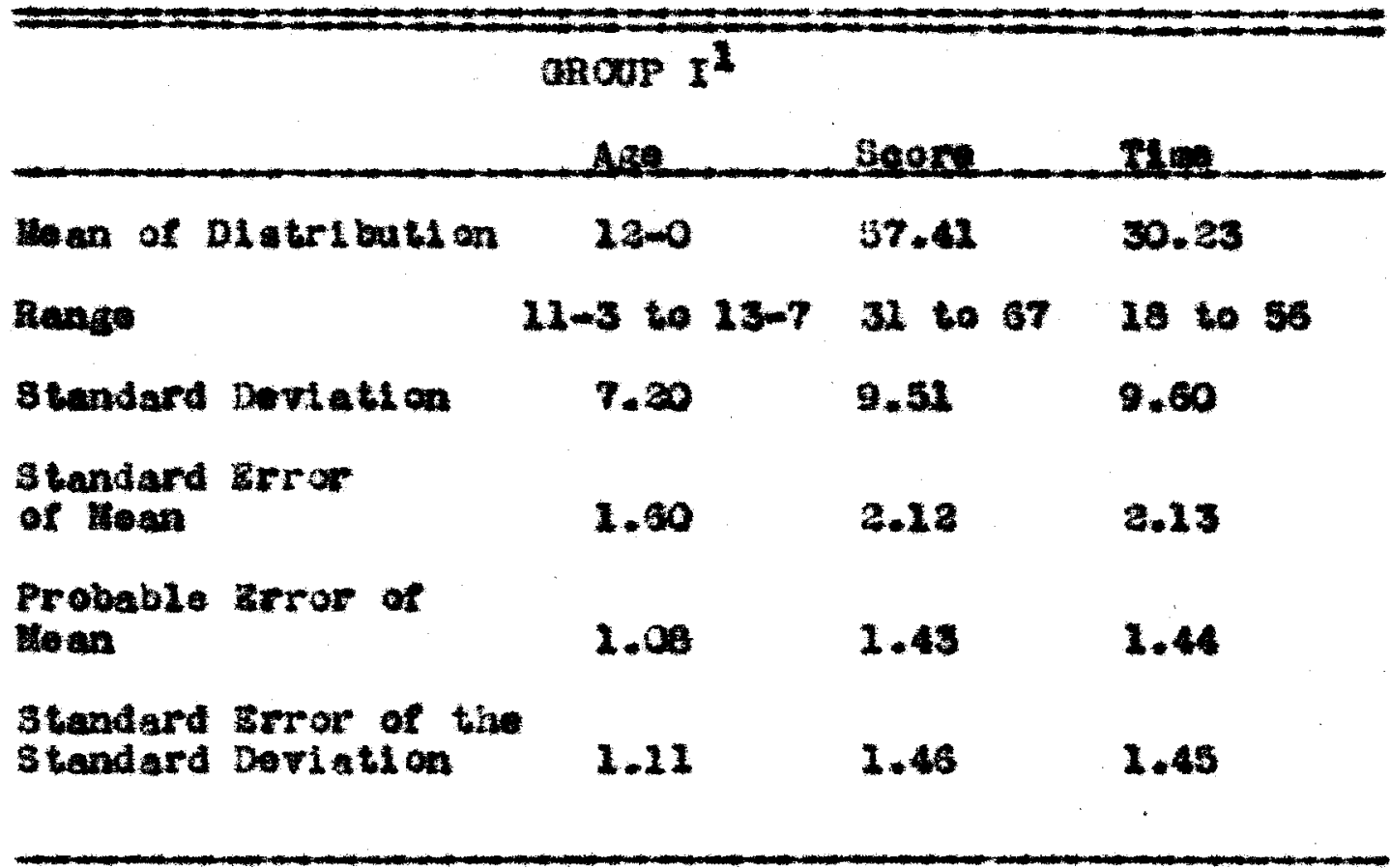

1. Aroup I refars to group of puplis tested on Etrope

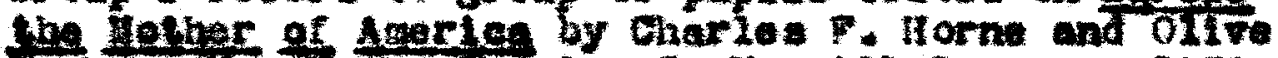

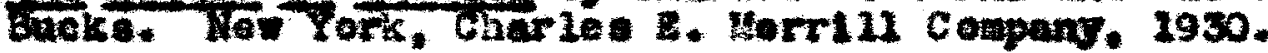




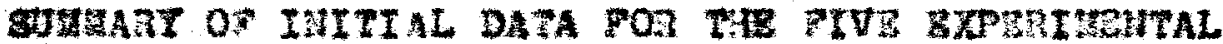

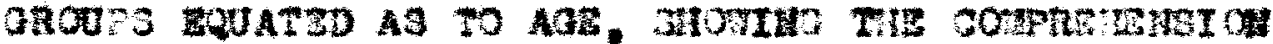
3COASS AND TITE OF DOUPLTHE TEST.

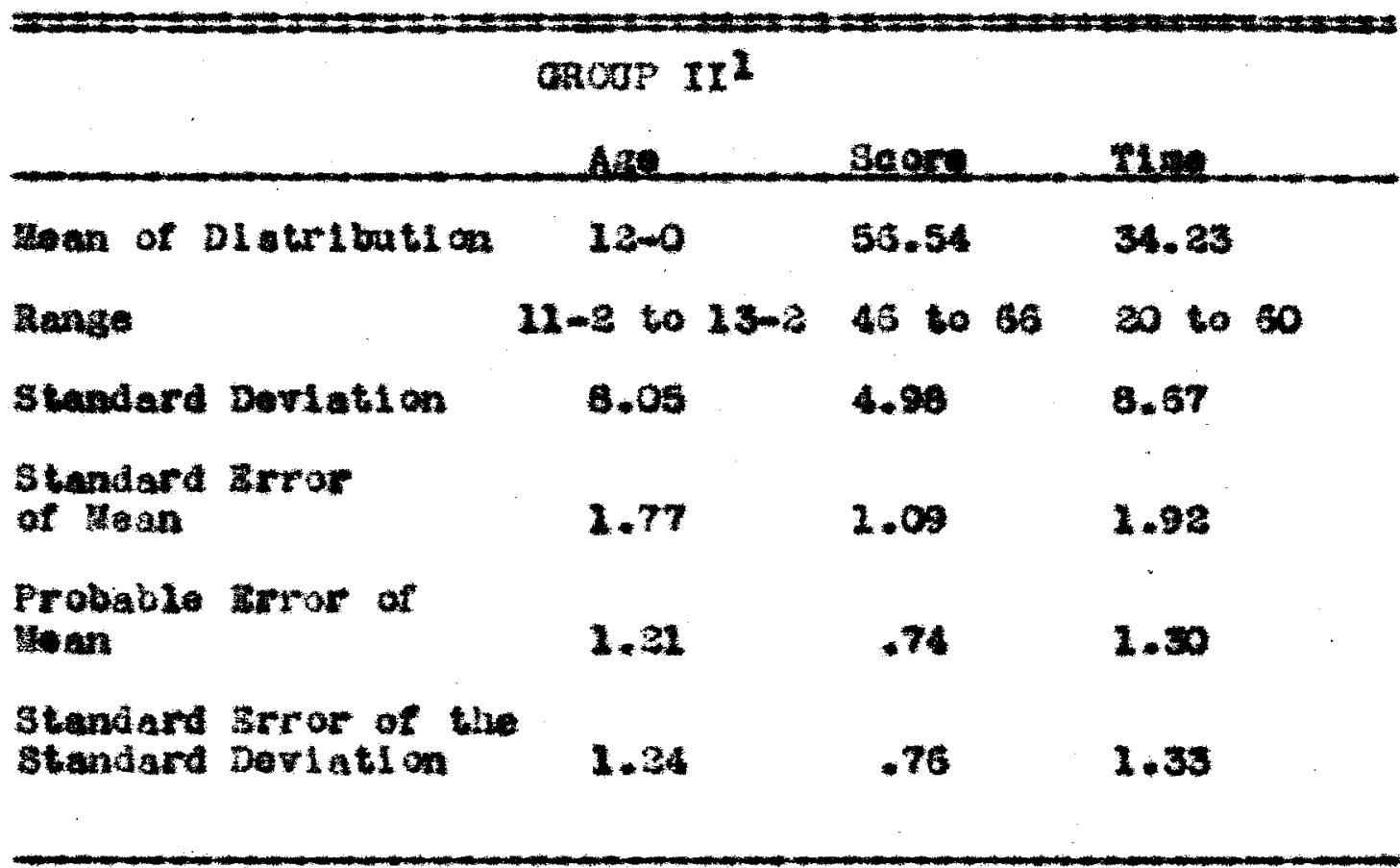

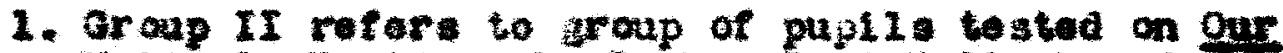

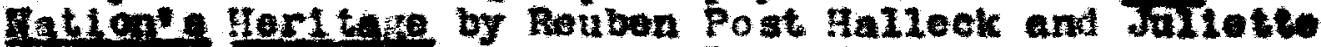

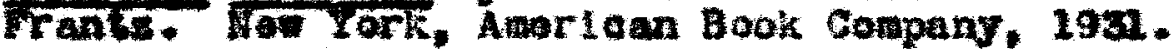




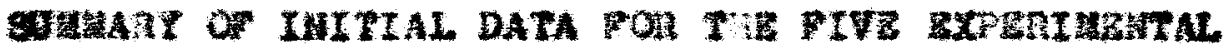

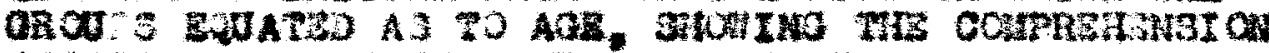

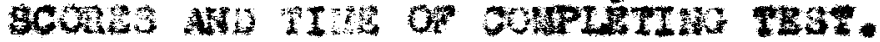

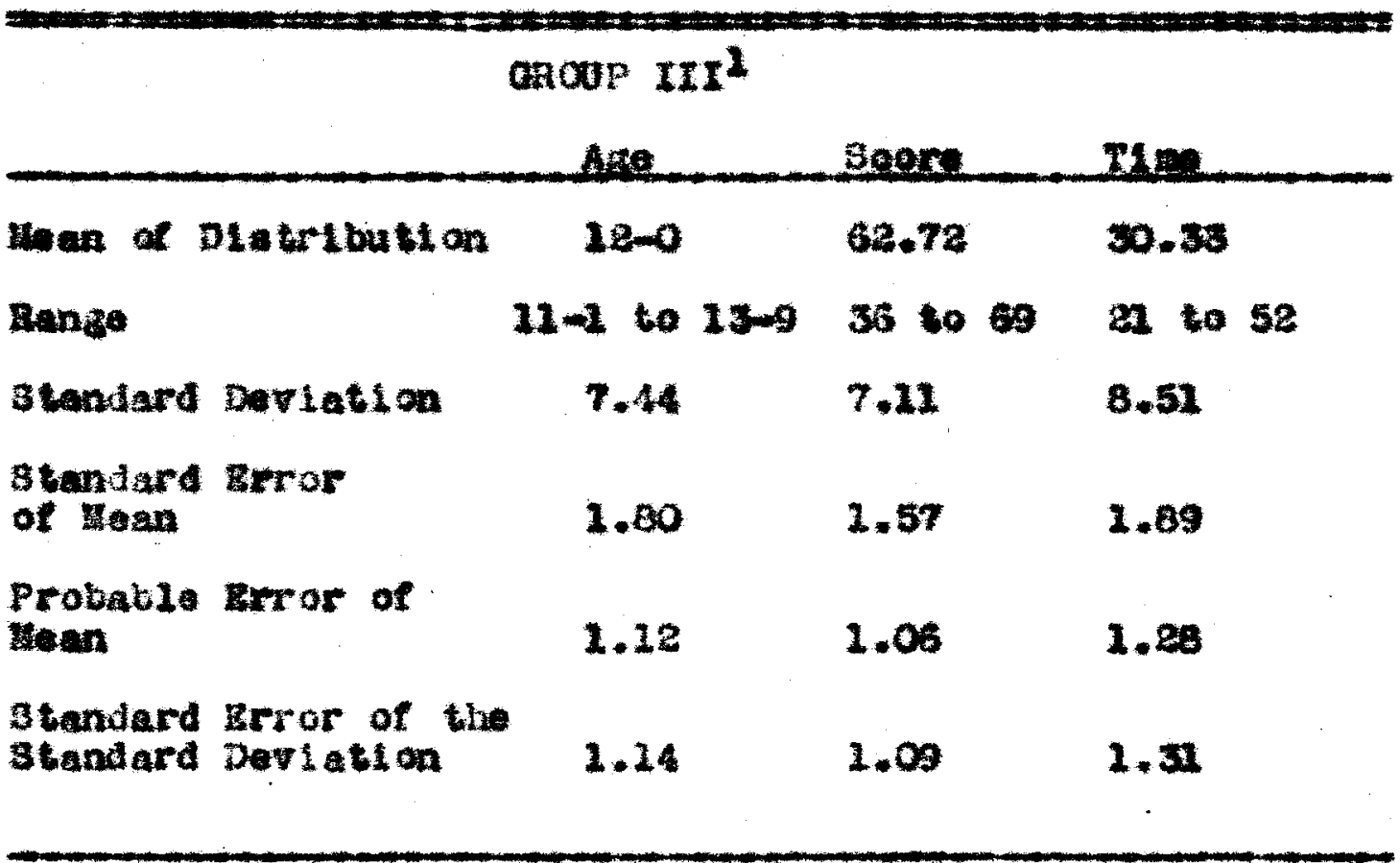

1. Group III refere to the group of pup1Is teated on The old yorid Baninnture by hary 0. Kel6y. Now Tork, ornn and Company. Isre. 


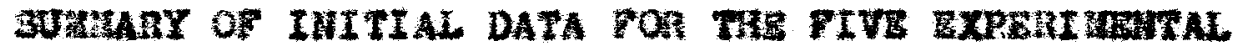

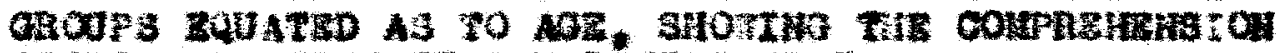
3Cons 3 AND hI

\begin{tabular}{|c|c|c|c|}
\hline & Are & Sege: & 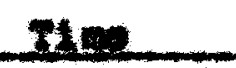 \\
\hline Wan of DI atribution & $12-0$ & 55.07 & 39.52 \\
\hline Ranise & $12-3$ to $23-9$ & 29 to 89 & 15 to 32 \\
\hline Standard Dertation & 7.00 & 9.27 & 14.06 \\
\hline $\begin{array}{l}\text { Dtanderd Exror } \\
\text { of Zean }\end{array}$ & 1.70 & 2.04 & 3.29 \\
\hline $\begin{array}{l}\text { Probable Brror of } \\
\text { Moan }\end{array}$ & 1.05 & 1.38 & 2.28 \\
\hline $\begin{array}{l}\text { \$tendard Error of the } \\
\text { Btandard Deviation }\end{array}$ & $1, \infty$ & 1.41 & 2.16 \\
\hline
\end{tabular}

1. Oroup IV retera to the aroup of puplis toated on

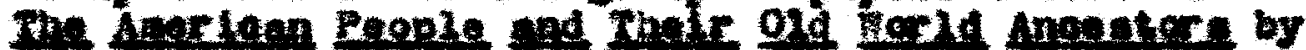
areos voximtine. Woi rork, aim and company. 1930. 


\section{TABLE X}

BUUA

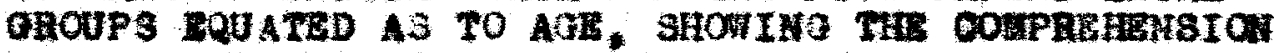
SCORES AHD TIE OF COMPLFTLA TRSE.

\begin{tabular}{|c|c|c|c|}
\hline & $\begin{array}{r}\text { anorp } \mathrm{Y}^{\mathrm{1}} \\
\text { Ane }\end{array}$ & enga: & PEa \\
\hline Moan of Digtribution & 18.0 & 62.00 & $35 \cdot 10$ \\
\hline Pange & $12-5$ to $13-4$ & $37+06$ & 161047 \\
\hline standare Devtation & 7.25 & 6.54 & 9.78 \\
\hline $\begin{array}{l}\text { Stendaro smor } \\
\text { of Hatan }\end{array}$ & 1.58 & 1.89 & 2.16 \\
\hline $\begin{array}{l}\text { Probable Brror of } \\
\text { Leen }\end{array}$ & 1.07 & 1.28 & 1.46 \\
\hline $\begin{array}{l}\text { Standard Brror of the } \\
\text { stundard Dertation }\end{array}$ & 1.11 & $1+32$ & 1.50 \\
\hline
\end{tabular}

1. Group reters to the group of puplis teated on the

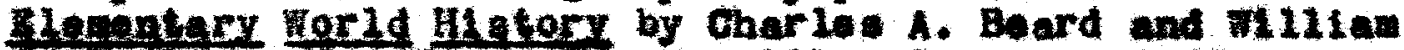
6. Bagloy. Won rork, Tho Magnillan Gompany, 1932. 
TAMLIX XI

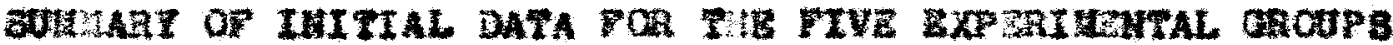

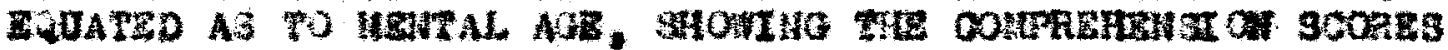

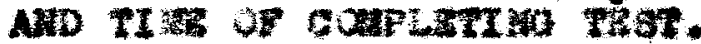

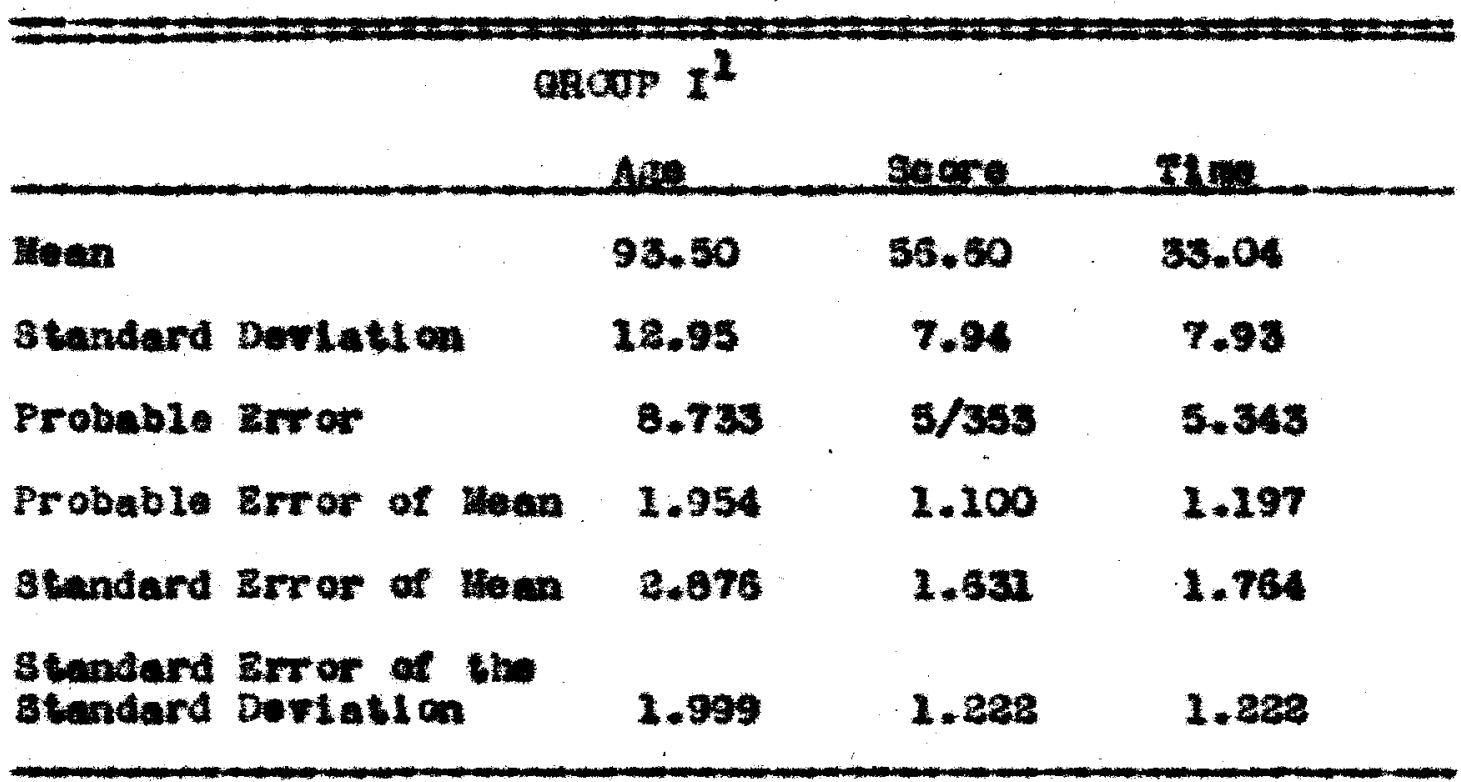

1. Oroup I retere to groap of pupl1s teoted an Burone the

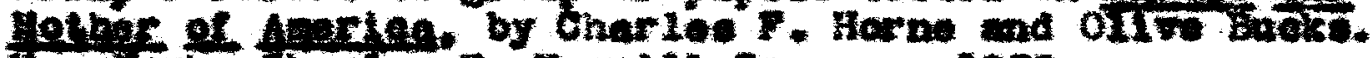

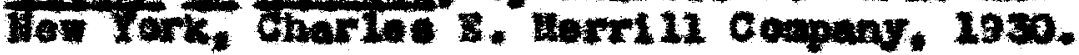


TABLE XI

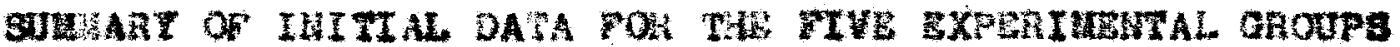
RQUAT2D AS $O$ O

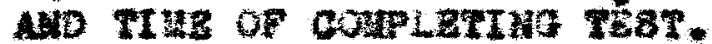

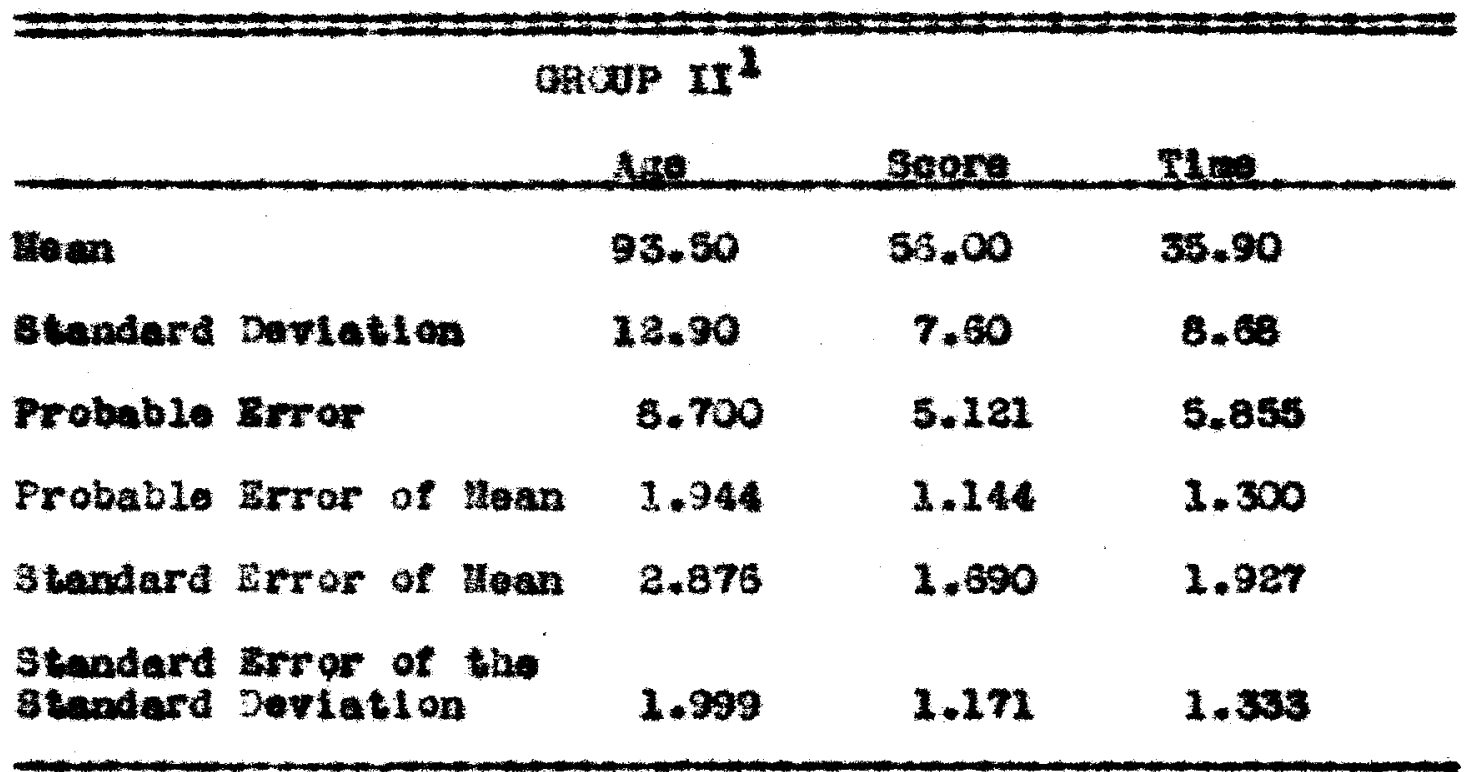

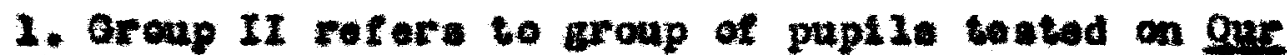

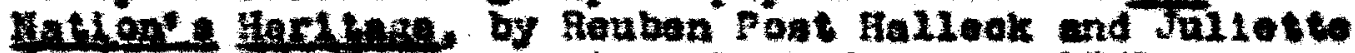

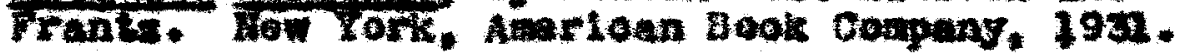


SUMARY OF IHITIAL DATA FOR THE FIVE EXPERTMENTAL GROOPS BQUATED AS TO mENTAL AGE, SHOTING THE COMPREHENSION SCORES AND TIRB OF CORPLETING TEST.

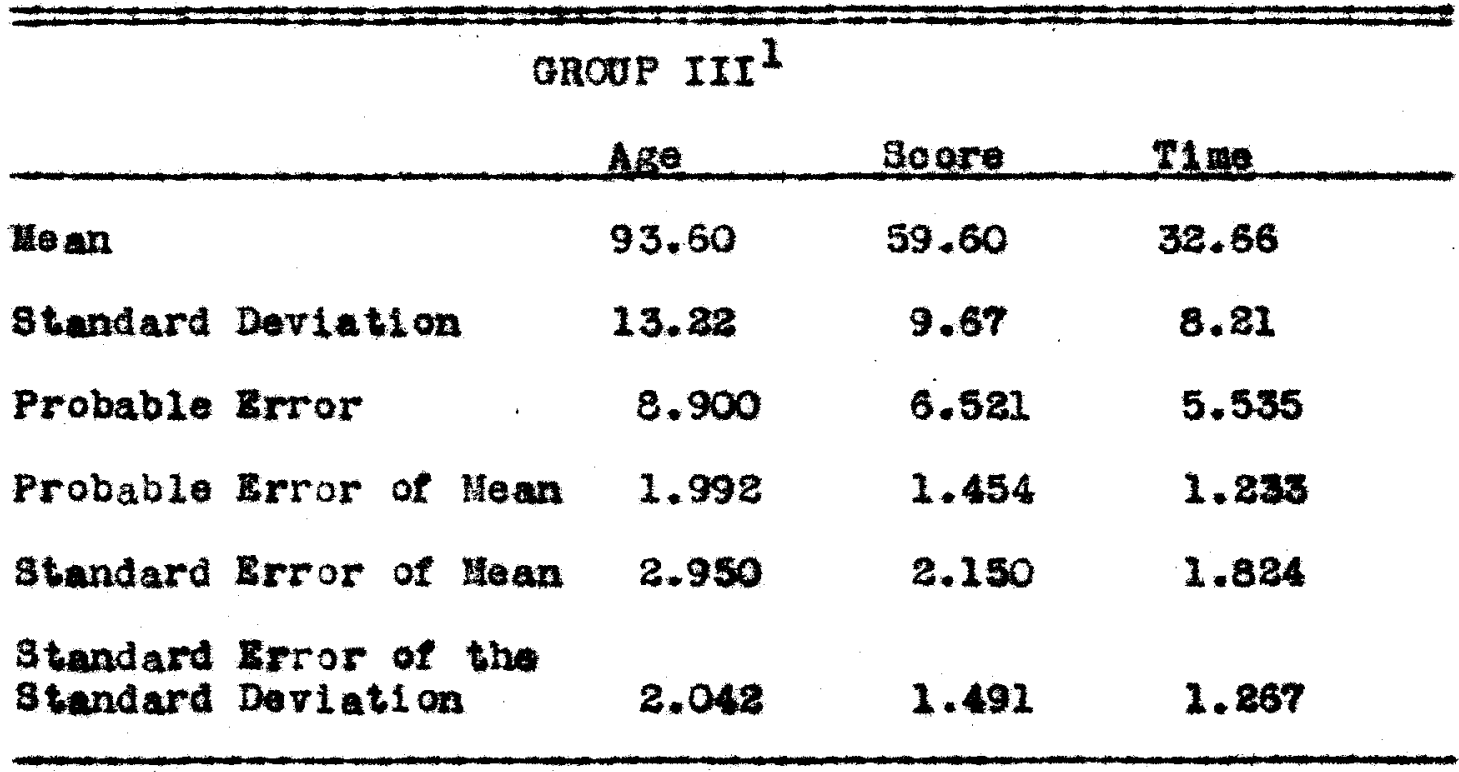

1. Group III refers to group of pup11s tested on the ord

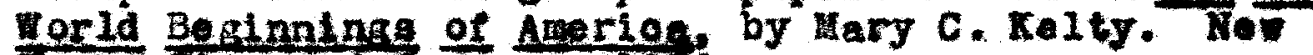
Tork, dinn and Company, 193:. 


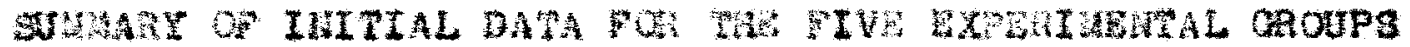

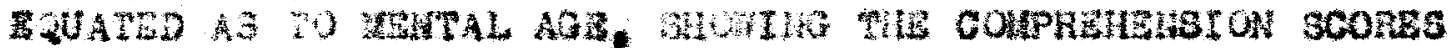

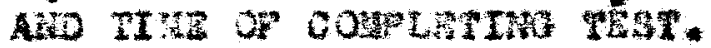

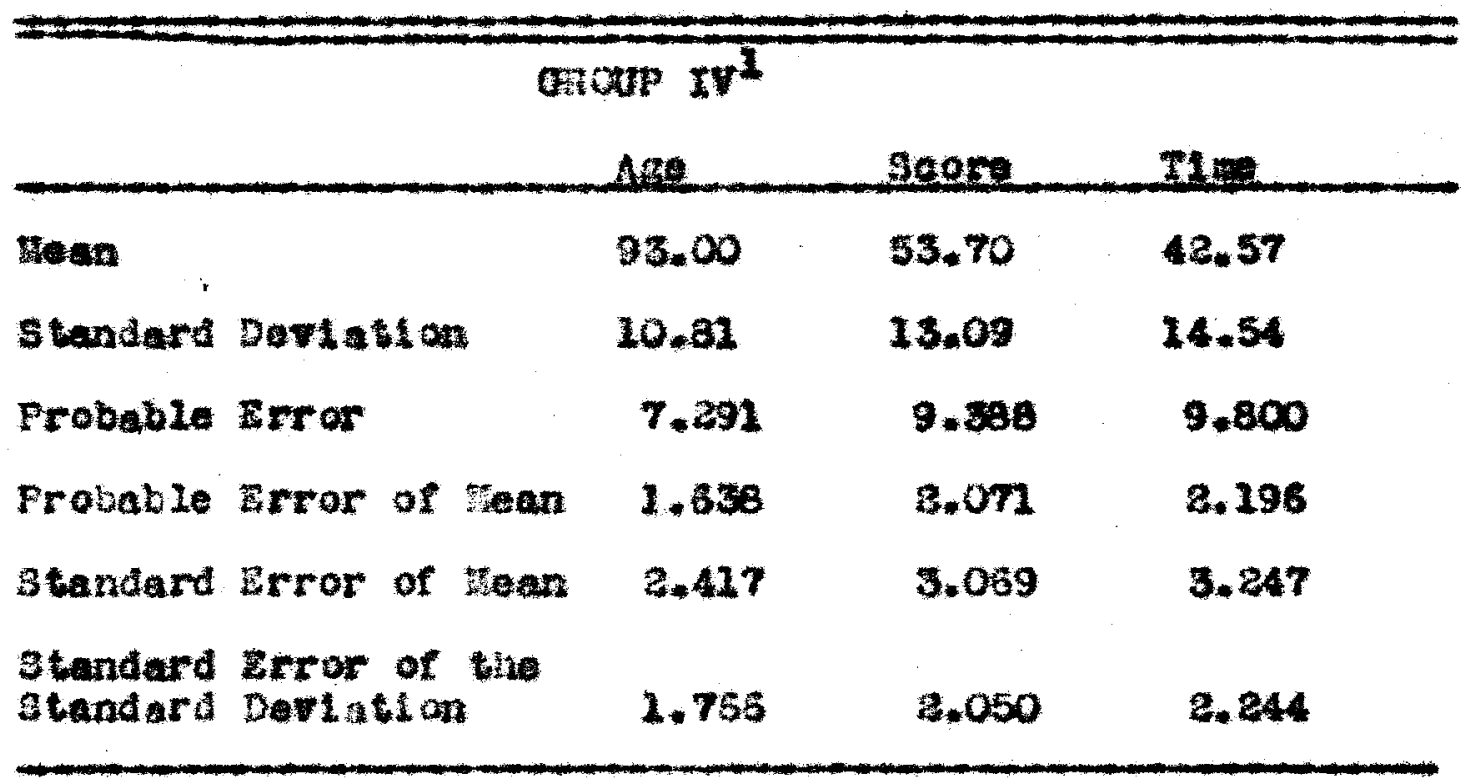

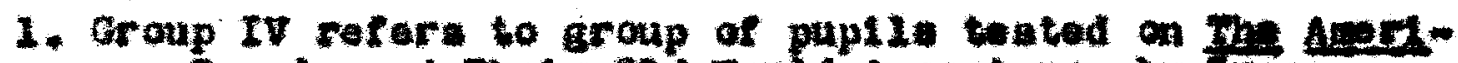

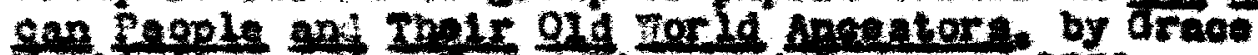

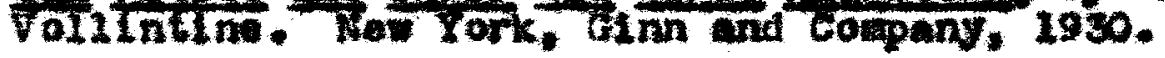


TALE X:

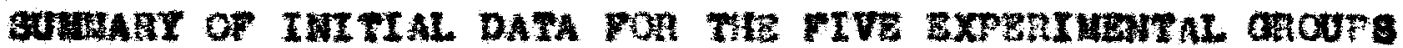

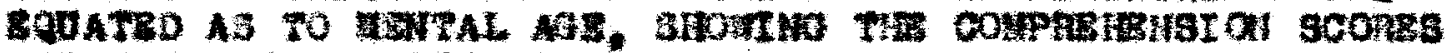

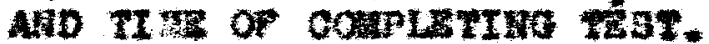

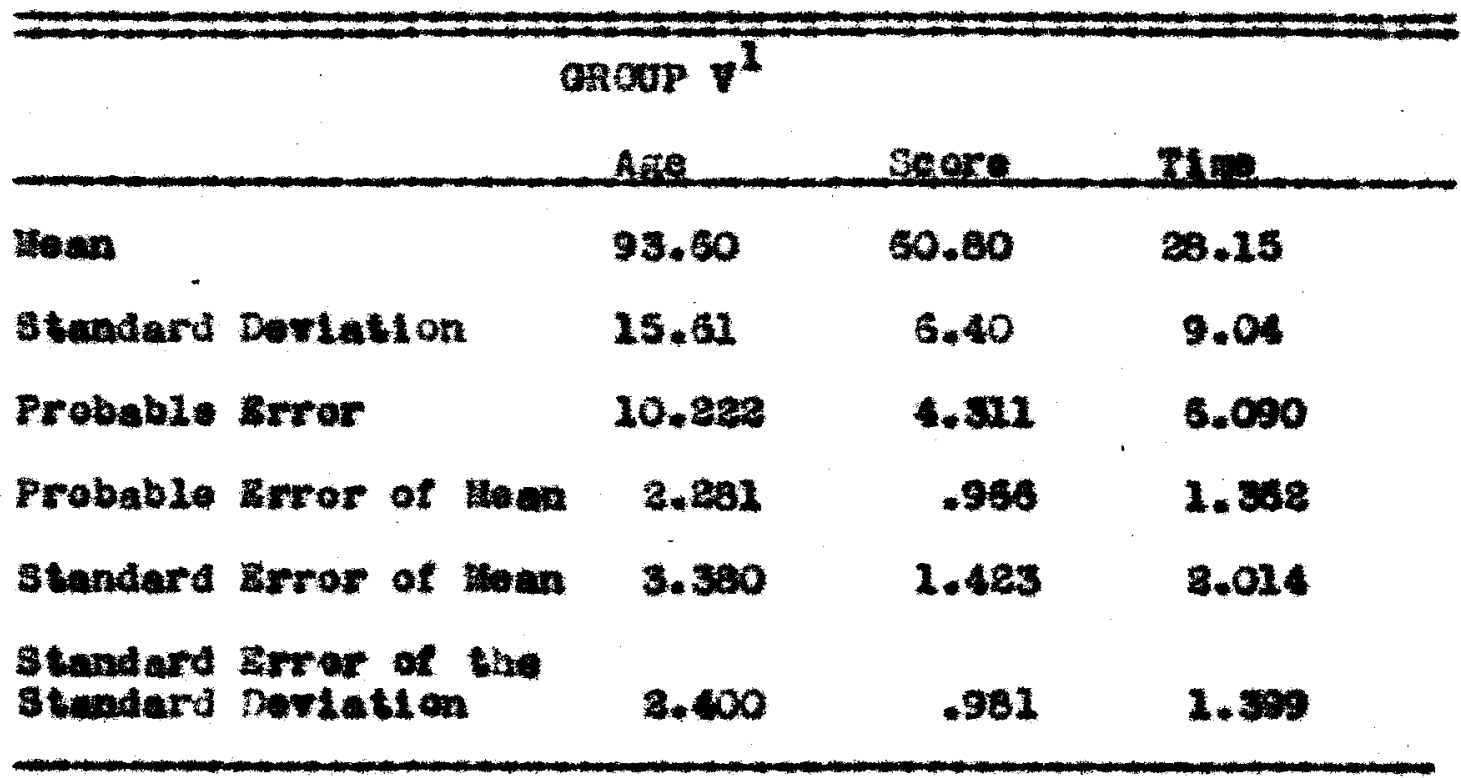

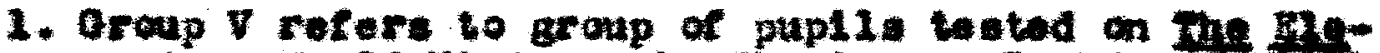

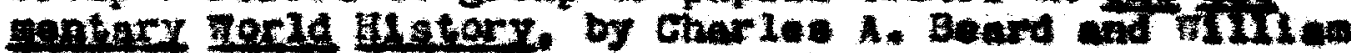

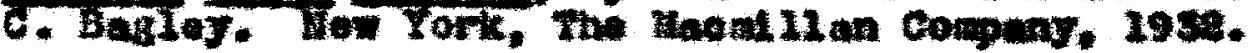




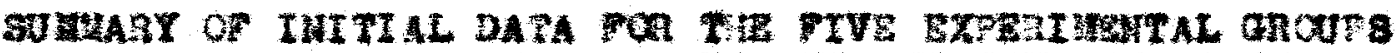

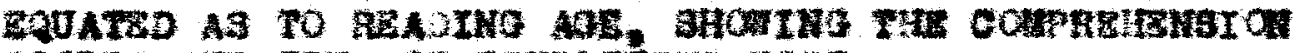

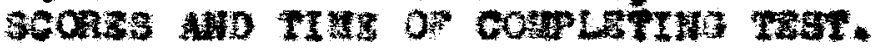

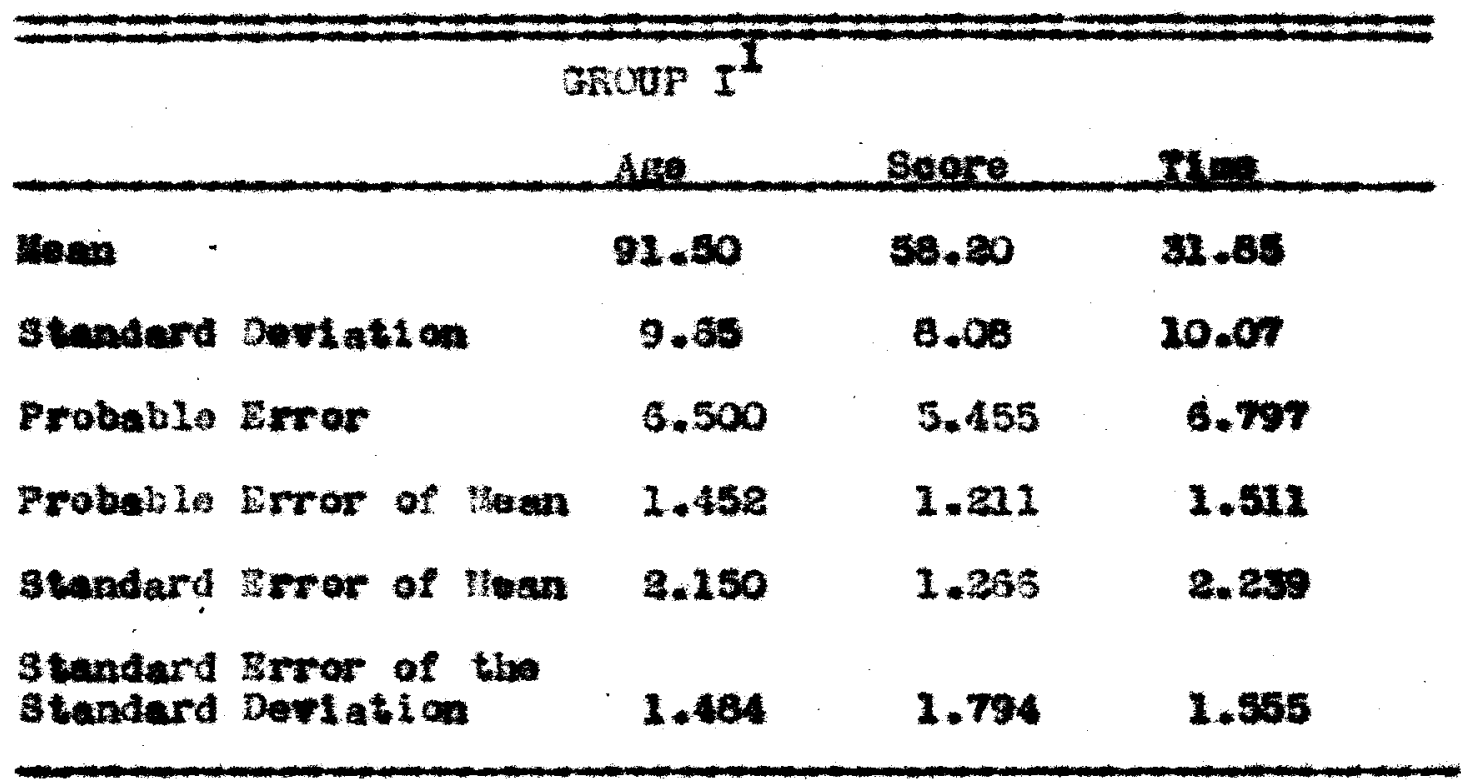

1. Group I rafers to graup of paptle tested on Earong the Hather of Anerlea, by tharles $p$. Horn and outre buoks. Fen Tork, banties $\mathrm{s}$. Werrill company. 1930. 
TABI XII

SUMAAT OF INITIAL DATA FOR THE FIVE EXPERIMENTAL GROUPS QQUATZD AS TO READINO AOE, SHOWING THE COUPREHEMSIOT SCORES AND TIUE OF COUPLSTINO TEST.

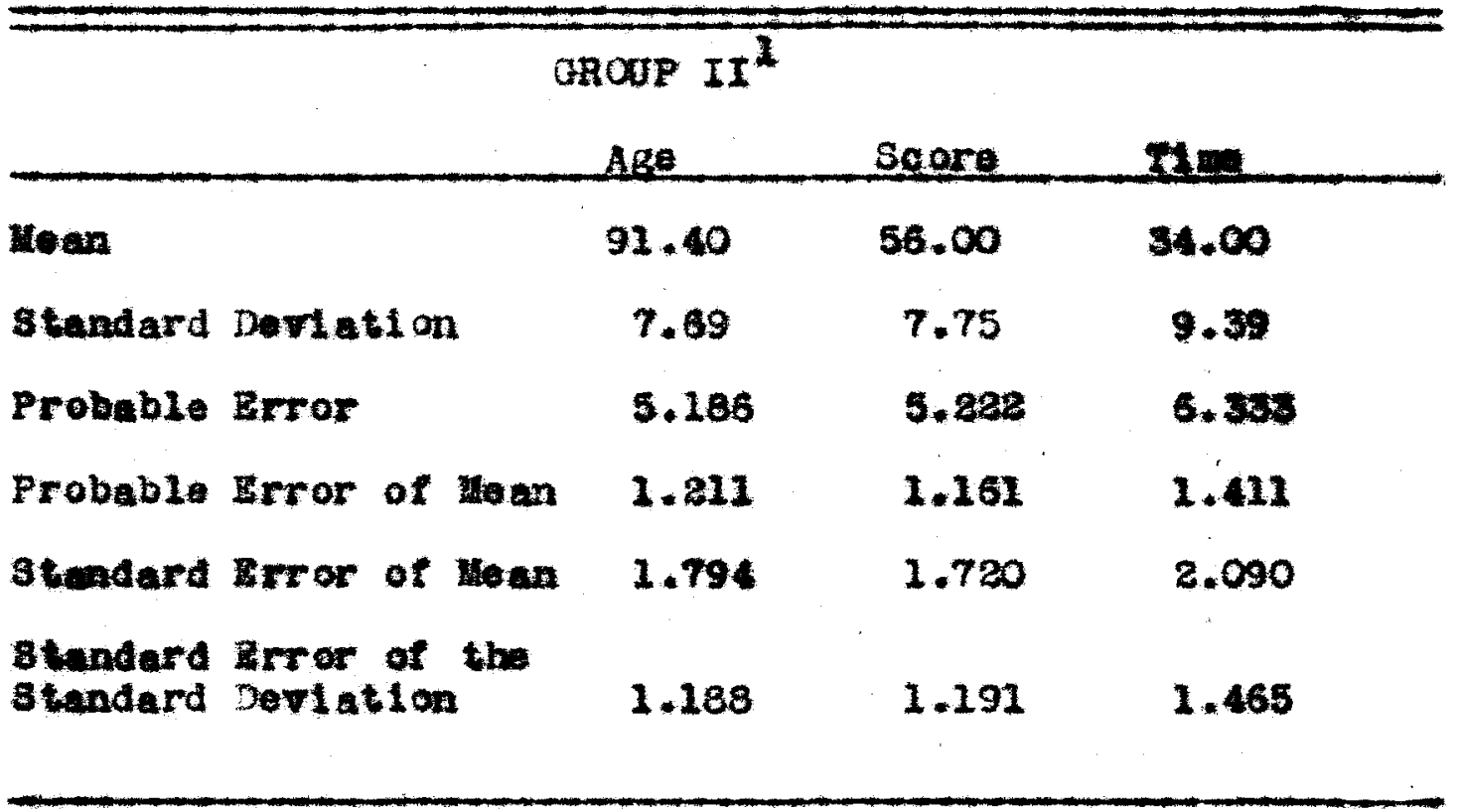

1. Group II refers to group of puplis tested an gar.

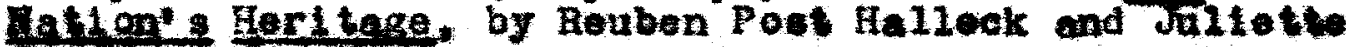
Fents. Lew York, Amerloan Book Gompany. 1931. 


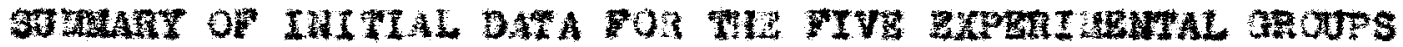

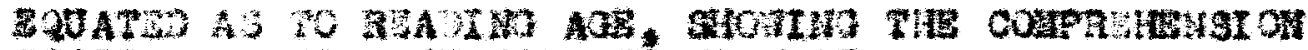

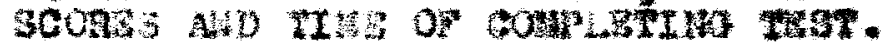

\begin{tabular}{|c|c|c|c|}
\hline \multicolumn{4}{|c|}{ GaODe $\operatorname{III}^{2}$} \\
\hline & Are & Seore & txas \\
\hline 数an & 91.90 & 90.50 & 35.00 \\
\hline Standird Daviation & 9.60 & 9.00 & 10.13 \\
\hline Probabla Brra & 6.474 & 6.078 & 6.832 \\
\hline Probable Error of zean & 1.444 & 1.356 & 1.524 \\
\hline Stendard 2 wor of 㥿ean & 2.135 & 2.002 & 2.254 \\
\hline $\begin{array}{l}\text { 3tandard Error of tho } \\
\text { Standard Dovlation }\end{array}$ & 1.431 & 1.380 & 1.568 \\
\hline
\end{tabular}

1. Group III refor to aroup of pupila tested on The out

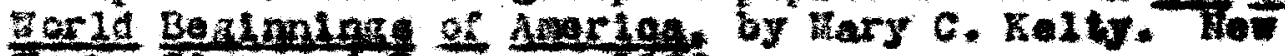
Tork, dinh and Company, 193e. 
TAOLE XIX

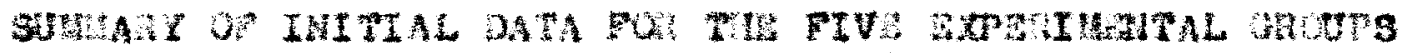

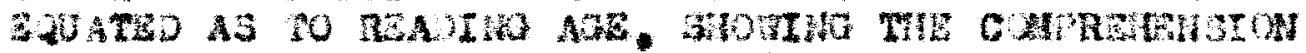

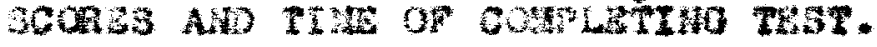

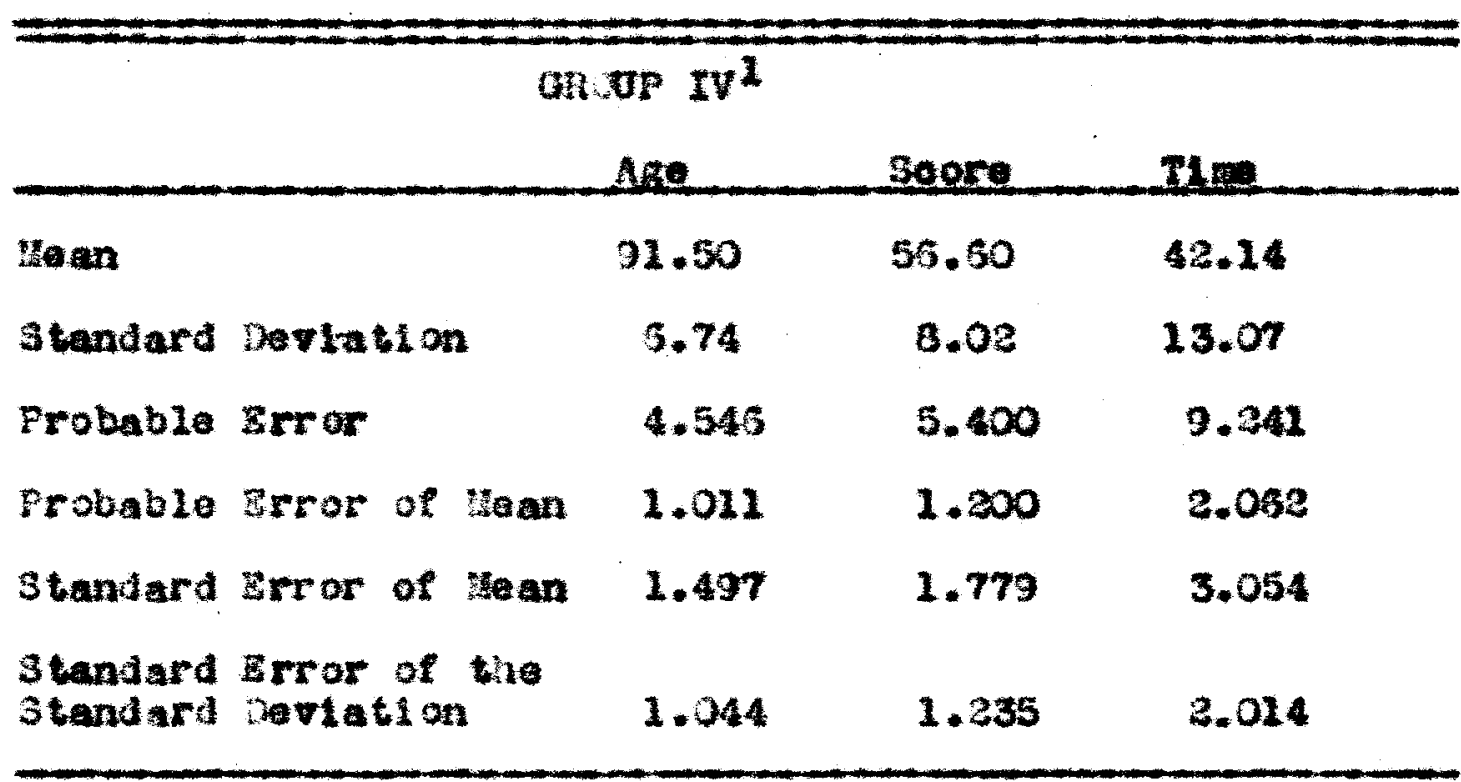

1. Group IV refers to group of puplis teated on the Aaertcan People and Their old world Ancestare, by trace Vollintino. Hew York, $8 \mathrm{~mm}$ end Corapany. 1930. 
TABLE XX

SOMUARY OF IMITIAL DATA FOR TIE FIVE EXPERIMENTAL GROUPS EQUATED AS TO READIHG AGR, SHOWING THE COMPREIENSION SCORES AND IIUE OF COMPLETING TEST.

\begin{tabular}{|c|c|c|c|c|}
\hline & & $\begin{array}{l}\text { LOUP } V^{1} \\
\text { Age }\end{array}$ & Soore & PI 100 \\
\hline Mean & & $92 \cdot 40$ & 60.60 & 25.67 \\
\hline Standerd & Deriation & 9.48 & 8.36 & 8.55 \\
\hline Probable & Error & $6 \cdot 394$ & 5.533 & 5.764 \\
\hline Probable & Error of tean & 1.425 & 1.252 & 1.282 \\
\hline Standerd & Error of taen & $2+105$ & 1.853 & 1.898 \\
\hline $\begin{array}{l}\text { Standard } \\
\text { Stand ard }\end{array}$ & $\begin{array}{l}\text { Error of the } \\
\text { Deviation }\end{array}$ & 2.462 & $1 \cdot 291$ & 1.311 \\
\hline
\end{tabular}

1. Group V refors to group of pupils te sted on The Elementary world History. by Charles A. Beard and WIII am C. Bagley. Ne York, The Macmillan Conpany, 1932. 
APPENDIX B 
EUROPE TIE MOTIEY OF AMERICA - HORHE AND BUCKS

Namo School Grade

Da to Time

Direotions: 1. Read each paragraph.

2. Answer each question. Draw a line through the right answer as: "Loulswille is a (a) house (b) ezty (c) dog."

3. Work fast but ANSWER BACH QUESTION CAREFULLT.

4. Put your name at the bottom of each page right now---before you start to work.

\section{I}

Even the great Roman roads of stone, which had led all over western Europe. could no longer be used for travel. They were disappearing through noglect. Their very stones were carried of to bulld rude walls of defense. Folvos caine dom from the mountains and roand over the country. There was no peace anywhereexcept where some strong tribe had settled dom, and defended for 1 tself the eity or farraland which it hed seízad.

1. The stone roads of Rome were (a) neglected (b) well cared for (o) rebullt.

2. The stones from the roads were used to (a) bulld houses (b) rebulld the roads (c) bulld waIls.

3. The country was roaned over by (a) bandits (b) wolves (c) soldiera.

4. There was peace only for the (a) priests (b) common poople (c) strong tribes.

\section{II}

Chief of these peoples were the German tribes or Teutons (tu'tons), as the Romans called them, who lived in the Porests of Northern Europe. The se Toutons were the ancestors of the German and Bngli ah people of today. They were also the ancestors of rany of the people of 
France and Italy, because after they had gradually onquered those countries, they marrled the natives or brought their om fanilies to 11 ve in those landa. As almost all the American colonl sts came from western Furope. the Teutons were our ancestors also.

1. The Romans called the German tribes (a) Buropeans (b) Americans (c) Teutons.

2. The Teutons of Europe $11 \mathrm{ved}$ in the (a) north (b) south (c) east.

3. The Teutons of Europe were anceators of the (a) Spanish (b) Franch (c) Germans.

4. Almost all the American colonists were related to the (a) Teutons (b) French (o) Spanish.

Charlemagne belleved that people should have achools. Besides those will ch had grown up in the monasterles, ho started some himself. The main bohool was in Charlemagne" a omn palace, and he oommanded that the chlldren of his om ohlef 0210 wrs should gtudy there. Other ohildren were also admitted if the teacher thought the ohlld bright enough to ake edueating him worth while.

1. Char lemagne wanted the people to have (a) schools (b) no velools (c) many parks.

2. The chlidren of Charlamagne* followers went to achool because (a) tiey had to (b) they wanted to (c) there was nothing olsa to do.

3. Some chlldren went to Charlemagne"s school because (a) the teachere liked thea (b) they liked the teachers

(e) the teachers thought they were bright.

4. Charlemagne had the main echool in his (a) chureh (b) palace (o) courtyard.

\section{IV}

England, at firgt known as Britaln, had boen ruled like most of Europe by the Romans. Then the Roman Empire vas ruined, some Touton tribes called Angles and Saxons conquered Britain and gave their om namo to it--Angle-Land. They did not draw together under a single great leader, as did the franks under Char lemagne. They did, however, form 
a group of little kingdons and enjoyed some peaceful years. Their wonk becane noted for thoir soholarship.

1. England was first called (a) Rome (b) Britain (o) Ang le-Land.

2. After the fall of Rone, England belonged to the (a) Franks (b) French and Engli sh (c) Angles and Saxone.

3. The Ang10-Saxons (a) united with France (b) had one leader (c) forned a group of little kingdoms.

4. The Anglo-3axons had peace for (a) some time (b) long time (c) not at all.

Every year the Vikings sailed south with over larger lleets of their alft ships. After while they but2t strong camps on the Freneh and English ooasts and stayed in these camps all winter. Thus they could begin their robberies earilier the next apring. The coast efties became too exhausted, too rulned, to make any defense.

1. The Vikings salied (a) north (b) south (c) southeast.

2. The Vlkings stayed in their camps all (a) year

(b) winter (o) all spring.

3. The coast cities did not flght the Vikings because (a) they were too walk (b) they had no ships

(c) they were afraid.

4. The Viking shlpo were (a) slow (b) clunsy (c) swift.

\section{VI}

Always, as Liaf and his followers advanoed, the shore becaine more warm and sunny and green with woodlands. They found it different indeed from the dark, fogeg land they had lirst di goovered. At length one of then, wandering inland, found great quantities of wild grapes. They then declared the new ocuntry was well wortb settilng in, and they called it Vineland or Vinland. As the saga gives no exact looation, we are not sure just were Viriand was. Perhaps it lay on the shores of Nova Sootia in Canada. Perhape the explorers had reached as tar south a New England. 
1. The land that Lief found firat was (a) aunny (b) 1 oggy (c) hilly.

2. Vinland was on the shores of (a) Virginia (b) Maine (c) Nova Scotia.

3. Vinland gets its name from its (a) woodlands (b) grapes (c) sunny skies.

4. Lief's followere found (a) grapes (b) apples (c) corn.

\section{VII}

For many years Alfred fought the Danes. He bulit himeelf new ships, swifter and stronger than those of the Danes. These pursued and captured many Danish shipa before the ralders could do moch harre. This fleet of Alfred"s wh the beginning of the now $f$ amous Engli sh navy.

1. Alfred fought the (a) English (b) Danes (a) Fronoh.

2. Alf red's ships won out because they were (a) big (b) many (c) swift and strong.

3. Alfred's floot was the beginning of (a) the English Nary (b) the French Nary (c) the Armada.

4. Alf red's ships chased and caught (a) many of (b) a few of (c) all of the enemy ships.

\section{VIII}

The more ignorant people of Europe did not realtze the difficulty at all. Thousands flung thamselves into the Crusade as though it had been no more serious than their usual fighting. They did not know that they were attempting a long journey. They did not se that thls journey would be $f$ ar more terrible than any battle with the Turka which might come at the end of it. Then only fel pilgrims had been traveling to Jerusalen, they could gather $f$ ood upon the way. But there was no food ready $f$ or a great army.

1. The ignorant people thought the Crusades would be (a) hard (b) easy (o) about like an ordinary fight.

2. (a) thousands (b) hundreds (c) millions of people went on the crusades.

3. The Crusaders went to fight the (a) Germans

(b) Turks (c) Jews. 
4. The $f$ ood on the way was enough $f$ or (a) many (b) fev (c) none.

\section{IX}

Af ter the Crusades there continued to be an active trade witin Asia. The East was glad to get grain, oll, metals, wool clotin, leather, and furs erom the West. These products were carried to Eastern ports by I talian merohants. Then the boats were loaded with Eastern goods and returned to Italy.

1. The ships to the Bast carried (a) w001 (b) wool cloth (c) coffee.

2. The merohants that took goods to the Bast were from (a) Italy (b) Asia (o) India.

3. Trade with Asia caine (a) during (b) before (c) af tor the Crusadeq.

4. The boats that carried Eastern goods to the West were from (a) Italy (b) Asia (c) India.

\section{X}

Now men learned about other pleces and different ways of living. The eivilization of the East was in many ways better than that of Europe. The homes of the Eatiern people were not only iner ones, but they showed moh more artistle beauty than those of Europe. Beautiful mage on the fioors and fine tapestry on the walls made the home of Eastem people a delizint to visit. Their clothing and jewels were richer than those of Europeans. Inventions made 1110 asier for then. Windilils, first seen in the East, were now copied for use in Holland and other lands.

1. The eitilization of the East was (a) better (b) worse (a) about the same as that of Europe.

2. Life for the Eastern people was made easy by

(a) batho (b) jewels (c) inventions.

3. Wind int were firgt seen in (a) the East

(b) Italy (c) Molland.

4. The poople of the East wore (a) ragged (b) elne (c) ugly clothing. 
There now arose a man of such power and such wisdom that he made these new instruments do a great work for mankind. This farous leader belonged not to the Italian merohant clties, but to Portugal. He was of the royal fally there. He is known as Prince Henry the Narigator.

1. Prince Menry made new (a) sea routes (b) instruments (c) furníture.

2. Prince Henry lived in (a) Portugal (b) France (c) Italy.

3. Prinoe Henry was a (a) teacher (b) soldier (c) navizator.

4. Prince Henry was a great help because he was (a) rich (b) royal prinoe (c) a tiso men.

XII

Each village had a school in which the priests taught the Indian children as mach as was posible of European idess and ways of living. Indian girls wero taught in these hools wh the boys. The misal ons were to the Indlans what the monasterles were to Europeans in the Dark Ages. The priests and monks we re doctor and nurses, Parmers and gardeners. Traces of their carefully tended gardens still linger in the courts, or patios, of some of the old missions.

1. The priests taught the Indian children to (a) make lace (b) make bows and arrows (c) Iive like Europeans.

2. Indian girls and boys (a) went to the same schools (b) went to different schools (o) did not go to sohool.

3. The missions were like (a) factorles (b) stores (c) monasteries.

4. The priests and moniss did the work of (a) servants (b) dootors (c) soldiera. 


\section{XIII}

The chief products brought home fron Roanoke had been tobacco and potatoes. We have seen hom the Spanlarda had learned from the Indians to use tobacco. Now Ralelgh set the fashi on of it in England. He Prequently smoked a pipe at court. and there is a lagend that Elizabetir would sit beside him almingly, sniffing at the smoke.

1. Tobacco was brought from (a) Rome (b) Roanoke (c) Spain.

2. The fashion of gmoking in England was set by (a) Raleigh (b) Elizabeth (o) Roanoke.

3. Queen Elizabeth (a) smoked a pipe (b) used snuff (c) liked to smell tobacoo anoke.

4. Tobacco mas used Plrst by the (a) Indians (b) Spanish (o) English.

\section{XIV}

The syster of feudalism was based apon the idea that all land belonged to the king. The word "feud" or "Plef" mant an astate or large $f$ arm. The estate of each noble came to him as a sort of gift from the $\mathrm{king}$ or a noble of high rank. Each one who received a gift of land owed "feuda?" service to the giver, and was called his "vassal." He in turn might grant parts of his plece of land to rassals. Each rassal took an oath of homage to his lord. He agreed to fight for him and to pay him certain service or dues in money. The actual work on the farms was done by the lowest class of peasents, called "serf s." They were almost like slaves for they could be sold with the land. They worked a part of each weak on their lord*s land in return for the privilege of farming a little strip for thenselves.

2. A flef was a large (a) town (b) man (c) farm.

2. The person who reoelved a gift of land was oalled a (a) vassal (b) lief (c) lord.

3. The work on the farms was done by the (a) lords (b) serf s (c) vassals.

4. (a) gerfs (b) vassals (c) flets could be sold wi th the land. 


\section{$x V$}

Now there sprang up in Germany the ldea of printing by movable letters which call type. In this way on pase of a book could be quickly set up and printed from a set of type; and later the sane type could be used for setting up another page. The old way of making books, as you wil remember, was by writing them out by hand. as the monks did in monasteries. By this new way of printing froi a sot of type, books could bo made many times more quickly, and tivey rapldiy became mich cheaper.

1. Printing of th movable type began in (a) France (b) Italy (c) Germany.

2. Honka wrote books (a) on atone tablets (b) by hand $(a)$ on printing pressa.

3. With novable letterg they could (a) print a wiole page at one tine (b) print piatures (o) move the letters on the page.

4. Movable type made books (a) more expengive (b) cheaper (o) scarcer.

$X V I$

It was in the year 1588 that the Invincible Armada finally set forth to oonquer England. A hundred and thirty Spantsh warships salled ith stately slowness up the English Channel. They advanoed in a great crescent, defyln: Bnglish attack. On the coast of what is now Beiglua but as then province of Spain, the Spanish army awatted their anips. These wore to carry the fierce spanish warriora acrose the narrow arm of the sea which alone kept then out of England.

1. The Arrada tried to beat the (a) Engllah (b) Spani sh (a) Frenoh.

2. The Armada vas made up of (a) ships (b) soldiers (c) airplanes.

3. The Armada belonged to (a) England (b) Italy (a) Spain.

4. The Armada carried (a) soldiers (b) 011 and coal (c) ailk. 


\section{XII}

Ainost at once Cortes contrived to malio a prisoner of the Aztec eraper. The bold spantard then gave comnands and ruled in the ouperor naw. Then the Azboes realized what hat inpponed, woy fought desporately to eroe their leader and drive out the Spaniards. One fleroe battle followed another, for tho Azteos vere brave warriora. hey fought win bone-tipped arrows, bronzo Javelins and tomahatus of stone. Even the iron weapona and the cannon of the Spaniarda could not turn the back. The Aztoos thought hat tha horsea and arnor of the Spaniarda we part of the the invader seers to them ilke four-legiod anonster 1 thich of stron. Then they la arned that the hor wa separate and not a part of live warrior, they at tacked oo hor se fron bentati.

1. Cortes made the Aztec trmeror a (a) kntgat (b) prianer (c) priest.

2. The Aztec carrior were (a) weak (b) brave (c) comardis.

3. The Aztecs foupint to (a) k11I tho 3pantards (b) capture the spanlarda (c) fres thelr lender.

4. The Spanlards lought with weapons of (a) tron (1) $\operatorname{sog}^{2}(0)$ steel. 
OUR NATCON'S HERITAGE - HALLECK AND FRANTZ

Name School

Qrade

Date

Time

Di rections: 1. Read each paragraph.

2. Answer each question. Draw a line through the right answer as: "Louisvilie is a (a) house (b) efty (c) dog."

3. Work last but AESTER EACH QUESTT ON CAREFULLY.

4. Put your name at the bottom of each page right nom--bef ore you start to work.

Among the remarkable things in the Roman Empire were the roads on which armies, traders, and travelers could more quickly from one place to another. Rome taught the 1 mportance of good roada in the development of a country. From Rone as a center, perfeot roads, hard, wide and smooth as city streets, radiated to all parts of the ampire. The Roman roads have atven us one of our proverbs: "All roads lead to Rome." Important roads went di rectly in stralght IInes irom place to place. In planning them, the Romans ware not blooked by mountains, rivers or smamps in the way. Mountains wore tunneled, and rivers and marshes were spanned by bridges. We say today: "Fun a Rowan road through it," an expression which means "go right ahead and allow nothing to block the way." When we ride today over parts of the old Roman roads in Italy. France, and England, we cannot deny that the Romans were the great road bullders of the worid.

1. The roads of Rome were (a) rough (b) rutty (c) smooth.

2. Rome showed that (a) rouds (b) schools (c) baths were most important in bullding a country.

3. On the Roman roads one could travel (a) slowly (b) rapidly (c) only short distances.

4. The main roads of Rome went (a) straight (b) along the rivers (c) over the mountains. 
To the sma 11, dark Romans, the tall, fair Ger mene and other Teutons seemed like giants. Their bodles were powerful and well developed. Their eyes were blue or gray, and their long halr, golden or red. This light hair was a source of wonder to the Romans, who made wigs of the halr taken from German prisoners. Many a Roman lady proudly wore the hatr of one of her barbarian nelghbors.

1. The Romans thought the Germans were like

(a) dwarfs (b) giants (c) falries.

2. The Romans used the halr of the German prisoners to make (a) brushes (b) wi 35 (c) cloth.

3. The eyes of the Teutons wero (a) black (b) brown (c) blue.

4. The Germans were (a) weak (b) strong (c) slok.

\section{III}

In 800 A.D. learning was at a very low stage in the Franki ah kinzdom. Even the great emperor himself could not read. He tried to learn how to rite, and used to ke p tablets under his plliow so that in his lelsure houra he might practice forming the letters. But he was never able to write any more than his name. Charlemagne found that some of the priesta ould not read. They simply learned the church service by heart from others. Wany of the best men in the Frankish kingdon had 11ttle education.

1. Charlemagne (a) was educated (b) could not read (c) was a Breat writer.

2. Char lemagne was (a) English (b) Spanish (c) a Frank.

3. Some of the prlests (a) betrayed Charlemagne (b) could not read (c) were excellent scholars.

4. Charlemagne kept tablets under his plilow so that (a) he could practice rriting (b) he would not lose then (c) the priesta mould like him. 
IV

The nowcomers practically destroyed Roman oivilization in the island. Many valuable things disappeared from use. For instance, coal had been used in Britain by the Romans, but was not knom by the early English nor used again until the twolfth or thirteenth century.

1. Roman civilization was almost destroyed in Britain by (a) the plague (b) mars (c) volcanoes.

2. The Anglo-Saxons did not know about (a) gold (b) ore (c) coal.

3. The English began using coal in the (a) twelth (b) twentieth (c) fif th century.

4. The newcomers to Britain (a) brought gold (b) protected the poor people (c) stole the treasures.

Across the North Sea, in what is now Norway, Sweden and Denmark, lived the Danes. They we re also called. Northmen, Norsemen, Normans or Vikings and were the piercest of the Teutons. They had taken no part in the early invasions of the Roman Empire by their kingmen. By the ninth century they were roaming the sea as heathen pirates. Therever a river mouth invited them, they entered, robbed the towns, and then salled away. Gradualiy the Northmen made settlements along the coast of Europe. The most famous, which Inoluded the reglon about the mouth of the seine River in France, still bears their name, Normandy.

1. The Danes were (a) Norsemen (b) Germans (c) Romans.

2. The Vikings were the (a) calmest (b) flercest (c) weakest of the Trutons.

3. The Northmen settled on the coast of (a) Africa (b) Asla (c) Europe.

4. At the mouths of the rivers the Norsemen (a) bullt homes (b) robbed the towns (c) burnt the towns. 
The Northmen settled Iceland and founded colonies in Greenland which lasted several hundred years. One band, under the leadership of Lief Erloson, even visited the mainland of America, about the year 1000. The Northmen explored the coast of Labrador. Newfoundland and Nova Sootla, and tade a settlement in what they called Vinland. The traded red cloth for the furs of the Indians. Then the white wen and the Indians quarreled, and many Northmen were kllled. The survivors left the Viniand settlement and went back to Greenland. Nothing remains to mark the site of the Vinland Settlement. Those in Europe who heard of the Northmen's story did not dream that they were hearing about a ne continent.

1. The Northmen traded (a) furs (b) jowelry (c) cloth.

2. Many Northmen wore killed when they quarreled with the (a) Spanish (b) Indlang (c) Engliah.

3. The oolonies of the Northmen in Iceland lasted (a) several months (b) a fow years (c) several mundred years.

4. The Indians traded (a) Iurs (b) jewelry (c) red cloth.

VII

The first years of Alfred's reizn were marked by fierce and continuous strugiles with tive Danes. Alf red knew that until the Danes were conquered, England could anjoy no peace or progress. He ordered his men to build ships larger than those of their enemies. Alf red has sometimes been called "the founder of the Bngllsh navy."

1. To have peace the English had to conquer the (a) Dowans (b) Danes (c) Germans.

2. Afred founded the (a) English Navy (b) English Army (c) Brglish Parliament.

3. The firat years of Alfred's reign were (a) easy (b) hard (c) useless.

4. Alf red had his men build (a) many canoes (b) large. ships (a) amall ships. 


\section{VIII}

Men of all classes from Christlan Europe joined armies that fought not only the Turks but also other Iohamedans in wegtern Asia at various times (beglnning 1096) for nearly two hundred years. These at tempts to drive the Uohamedans out of the Holy Land were called the Crusades, from the Latin word meaning "cross." The church sinowed 1 ts great influence in starting the Crusades. The Crusaders, to show their respect for the cross on which Christ died, wore a cross of red cloth. They captured Jerusalem (1099) and held it for nearly a hundred years. The Crusaders falled in their real purpose, for the Mouamedans took Jemsalem from them (1187) and kept it for more than seven hundred years. The Christians then recaptured it (1917) in the For ld "yar.

1. The Crusaders tried to drive the (a) Mohammedans

(b) Jens (c) Spanish out of the Holy Land.

2. The Crusaders Fore crossea of (a) gold (b) silver (c) oloth.

3. The Christians captured the Holy Land (a) once (b) twice (c) three times.

4. The Mohamedans took the Holy Land from the Christians ( $a$ ) once (b) twice (c) three times.

\section{IX}

During the Crusades rany Europeans settled in Syria, north of the Holy Land and engaged in trade. They sent ghips to Burope loaded with carpets, rugs, aliks, fine cloth, pepper. cltron, 1.6s, melons, steel mirrors, glass, and vases. Thus trade grew between the Eagt and Europe.

1. Uany Europeans settled in (a) the floly Land (b) Syria (c) the East.

2. Trade between Furope and the East was caused by (a) the Vor Id $\operatorname{Var}(\mathrm{b})$ the Crusades (a) the Revolution.

3. Ships to Europe carried (a) spices (b) gold (c) guns.

4. The Crusades caused many Europeans to becone (a) fishermen (b) traders (c) manufacturers. 
Europeans learned also to replace the 11 thy mishes on thelr loors with easern rugs and sarpets. They bought oft cloth ane of camel's antr in place of coarso

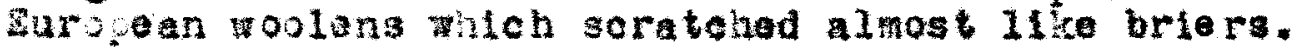
Fretty yellow, rad, and blue dyes wero brought from the Bast. Feoplo becane interasted in making their drass and nomes aore pleatns. Europsang also began to take nore care in the preparation of heir meals. Their food could be seasoned nith atem pepter. Binger, and nutrege.

\section{Zuropean tloors wore oovared wth (a) 2inoloub} (b) mige (o) malos.

2. European eloth was male of (a) $812 \mathrm{k}$ (b) wool (o) came 1" hair.

3. The ayes from the dast wero (a) blue (b) purple (a) istan.

4. In the East ho Europeans lo arned about (a) war (b) reading (c) sod homes.

Prince Henry of Portujal (1304-14b0), knom as the Navigator was one of the great xplorer 3 to use the wariner's coapass on long voyages. Vle tas the son of an Bnglish sother and portuguese iativer. lie had two very strong wishes: (1) to take the goapel of Chriat to tive reathen, (3) to explore the const of Africe and.

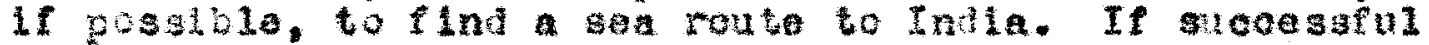

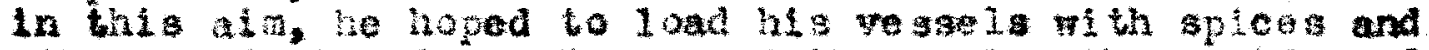
other products of the sat and thus solve the problan of IInding a better vay of bringing anch thing to Fur ope.

1. Prince Nonry was (a) king (b) cruaador (c) navigator.

2. Prinee Tenry manted to (a) discover a now morla (b) Ind nev ses rout to India (c) cature the $101 \mathrm{y} \mathrm{Land.}$

3. Frince lenry anted to becone (a) great ruler (b) areat tradir (a) alvo a bis problem.

4. Frince Henry itred in (a) Portagal (b) Tugland (c) Africa. 


\section{XII}

The Spanlsh priests brought the Indians to live in villages around a religious mision houge as a center. The old mission buildings are still to be seen in many places. The missions were schools as much as churches. The priests taught Indian childron and their parents how to livo in clvilized way. The Indlans leamed how to raise food and to make what things they needed. They were taught faring, carpentering, cooking, weaving, dyeing. and how to make clothes, leather, saddles, bridles, and shoes.

1. The priesta taught the Indians (a) Latin (b) farming (o) how to fight.

2. The old missions have (a) been bumed dom (b) been carried away (c) are still standing.

3. The Indians lived in (a) missions (b) villages (c) on small farns.

4. The mistons were (a) just schools (b) just churches (c) both schools and churchos.

\section{XIII}

Corn and tobacco, both found only in the New Wor Id, would have a prominent place in a pageant showing tho aettlement of Virginia. John Rolfe tried raiging tobacco in his garden before he made his visit to Lond on with Pooahontas. When he cane back after a two years" absence he found only $f i v e$ or $3 i x$ houses in Jamestown. Its streets vere planted with tobacoo. Its people had spread out in the country to raise tobacco. So it happened that Virginia became a colony of tobacco plantations and not of towns.

1. Virginia (a) built towns (b) manuf actured (e) raised tobacoo.

2. Tolacco was planted by (a) Pocehontas (b) John Rolfe (c) John Smith.

3. Corn and tobacco were found in (a) Spain (b) the New Tor ld (c) England.

4. Janestom was a (a) large ofty (b) small town (c) nanuf acturing center. 


\section{XIV}

The feudal gystem was a kind of government based on the holding of land. The agreement between each lord and his vassal called for duties both ways. The vasal had to fight in his lord's army, and the lord had to protect his vassal. When necessary, the lord gethered an army to fight of 1 invading enemiea. He also acted as governor and fudge to keep ordur among his rassals, conduct trials, and settle disputes. A rassal was subject to call to sit in his lord's court and to advise his lord. All vassals were required to pay money to their lord on special occaslons, such as for a ranson (price for settiniz a prisoner free) if the lord should be captured by an enemy, or for a dowry (large wedding gift) when the lord"s daughter was married.

\section{The feudal system was about (a) the king} (b) the solders (c) the land.

2. The lord was protected by (a) his armies (b) his vassals (c) his serfs.

3. The vassal (a) advised the lord (b) fought the lord (c) was a slave.

4. The lord and his vassals (a) heiped each other (b) fought each other (c) both worked for the church.

\section{$X V$}

In the twelf th century paper was introduced into western Europe by the Hoor in Bpain. A material oheaper than parchment was thus secured. Then in the fifteenth century the printing press was invented. Instead of writing one copy of a page at a time, the printer could strike off tive hundred copies of ach page if he wi shed, when onoe his type was set. William Caxton get up the first printing press in England. From his time on, books began to grow more and more plentiful and mon cheaper. The art of reading became common.

2. The first printing press in England was set up by (a) Fulton (b) Caxton (c) Thitney.

2. The printing press mede books (a) more expensive (b) smaller (c) cheaper.

3. Paper was first used in (a) Germany (b) Spain (c) Enisland.

4. Paper was used instoad of (a) printing (b) writing by hand (c) parchment. 
A battle that changed the history of the world was fought (1588) in the last half of 21 izabeth's relgh. Phillip sent agalnst England a loet whioh the spantards called the "Invinclble Armada" because they were sure it could not be defeated. There were about one hundred and thirty-two vessels in this leet as it entered the gingligh Channe1. Trenty-one thousend soldlers wore on board, and more were to be added from the Spanish army in the Netherlands. The combined force was to be landed in England to conquer it and annex it to spain.

1. The Armata was a (a) bullaing (b) army (c) fleet.

2. Tha ruler of England was (a) Phll11p (b) Alf red (c) Ellzabeth.

3. The Armada carried (a) soldiers (b) silk (c) gold.

4. The Arnada went to beat (a) Spain (b) England (c) Portugal.

\section{XVII}

Wile Cortes was at the coast, llontezuma, emperor of the Aztocs, was greatly troubled by the news brought him. The white strangers had death-dealing firearms and rode horses-an animal unknom in America. Monteauma sent Cortes many presents, among them two large wheels, one of gold and the other of silver, and a peok of gold dust. These presents made Cortos wealthy and roused his desire for more. They were sent as a bribe to cause cortes to leave ${ }^{2}$ exico, but they had the opposite effect. Cortes made up his mind to vigit lontezuma and get the rest of the Aztec traasures. He boldiy marched into the Aztec capl tal and evan took llontezuma prisoner. Af ter several months. however, the Aztecs began to fight under a new emperor.

1. Cortes was (a) weak (b) determined (c) comardly.

2. The emper or of the Aztecs was (a) Magellan

(b) Cortes (c) Montezuma.

3. Presents mare used as (a) bribes (b) rewards

(c) tokens.

4. The Aztecs (a) were conquered (b) beat the Spanish (c) became a province of England. 

School Grade

Date TI ne

Directi ons: 1. Read each paragraph.

2. Anawer each question. Draw a line through the right answer as: "Loulswilie is a (a) hou se (b) etty (c) dog."

3. Work tast but ANSWER EACH QUESTION CAREFULLY

4. Put your name at the bottom of each page right now-before you start to work.

I

Goods was carried ovarland also. Paved roads, so wo 11 made that sone of then are in use today. led out to the farthest parts of the Empire. There were so many of the mat poople sald. "All roads laad to Rowe." Along the sides of the roads were gtations where fresh horses were kept. By changing horges of ten a messenger oould travel over these highmays a hundred mile in a day.

1. Roman roads were (a) poor (b) short (c) good.

2. Roman goods could be sent (a) long di stancos (b) short distanoes (c) oniy to Rome.

3. There were stations at the sides of the road for (a) lunch (b) horses (c) soldiers.

4. Hessengers traveled fast because they (a) always went to home (b) changed horses (c) had to go so far.

One of these groups of people was called the Toutons or Germans. They we re lerce 11 ghters, and were so huge that they looked like giants compared with the pomans. They wore clothing ade from furs or rouzh mool. They Iired in huts made of twigs.

1. The Germans mere (a) very small (b) very large (o) about average.

2. The Germans fought (a) well (b) poorly (c) not at all. 
3. The Germans lived in (a) fine homes (b) of ty homes (c) poor homes.

4. The clothing of the Germans was (a) warm

(b) strong (c) flimsy.

III

Char lemagne himself as not very well educated, but he valued learnlng very highly. He knew some Latin and a little Groek, and he liked to make up poetry and riddles. Throughout his 11 fo he studied hard, and he even had stories about the great deeds of the Franks told to hit while he was at meals. But, to his sorrow, he never was able to learn to write, although he carried tablets about to practice on, and oven kept them under hia pillow at night so that he might practice as soon as he woke in the norning. He had begun too. late.

1. Charlemagne did not leam to write because he (a) did not try (b) was too old to leam (a) put his tablet under hi pilion.

2. Charlemagne thought that people should be (a) educated (b) rioh (a) neither.

3. Charlemagne $11 \mathrm{ked}$ to hear storiea about (a) cruel deeds (b) robbers (o) brave men.

4. Charlemagne $11 \mathrm{ked}$ to mako up (a) legenda (b) problams (c) poems.

The Anglo-Saxons were heathen; they worshlped the two gods Wodnesday and Thurgday are named). Like the other barbarlans, they preferred to IIre in the open country, so they burned what was left of the Roman towns. Thus they destroyed what ilttle remained of the Roman civilization; in time even the use of coal was forgotten in Britaln.

1. We use the names of Ang10-Saxon gods for some of the names of our (a) days (b) months (c) seasons.

2. The Ahglo-Saxons were (a) olvilized (b) uncivilized (c) Christians.

3. The Ang10-Saxons lived (a) in toms (b) in cities (c) in the country.

4. The Anglo-Saxons made Britain (a) a better place to live in (b) a poorer place to live in (o) kept it as it was. 
Then the Danes began to bring to these camps their women and thelr children and their oattle. They left their homeland forever and settled down in land they selzed from the Anglo-Saxona. History geemed to be repeating 1tself. What had happened centuries ago when the Ang10-Saxons drove the Britons out of the land was happening again. But thls time the Northmen, in their turn, were driving away the Anglo-Saxons.

1. The Danes brought their chldren with them because (a) they were af raid of the AngloSaxons (b) the re were no chllaren in Britaln (c) they were making homes in a new place.

2. The Danes got the $1 \mathrm{r}$ land from the Anglo-Saxons by (a) buying it (b) renting it (c) stealing 1 t.

3. When the Danes settled in Britain they took their (a) sheop (b) ales (a) cattle th them.

4. The Northmen drove the Anglo-Saxons out (a) just as the Danes had driven array the Northmen

(b) Just as the Angles had driven away the Saxons

(c) Just as the Ang10-Saxons had driven away the Britons.

VI

Llef discovered Vinland about the year 1000. We now think that he had found part of Amerlca. His mon spent very pleasant inter in Vinland and then sailed howe to Greenland, taking $\mathbf{1}$ th thers a number of $10 \mathrm{~g}$, for the trees in Greenland and Iceland were small. They also took some of the wld wheat that they had found and som of the grapes.

1. Vinland is a part of (a) North America (b) Europe (c) Asia.

2. Lief's hore was in (a) Iceland (b) Vinland (c) Greenland.

3. Lief took home loga wi th him because (a) there wero no bla trees in Greenland and Icoland (b) trees would not grow in Greenland and leeland (a) all of the trees in Greonland and Iceland had been cut down.

4. Lief took home some (a) tobacco (b) corn (c) grapes. 


\section{VII}

Alf red also defeated them in a great sea fight north of the Thames BIver, for he had been wise enough to bulld some ships as weil as to gather an army. He had learned that the Danes always ran back to thelr shipe wen they were defoated and then soon appeared again in another section of the country to make another attack. The ships which he bullt were very long and gtrong; they easily defeated the Danish ships.

1. Alfred defeated the Danes ith his (a) guns (b) ahips (c) airplanes.

2. Alfred's silps were (a) poorly bullt (b) well bullt (o) slow.

3. When the Danes were defeated (a) they went home (b) they disappeared forever (c) they came baok.

4. Then Alfred fought the Danes on the sea he $f$ and them (a) hard to defeat (b) easy to defeat (c) Impossible to defeat.

\section{VIII}

Late in the spring the main army was ready. There wer so many soldiers that they could not all go at once, but vere divided into five seotions. All the long journey had to be made overland, since not enough shlps oould be found to carry the people. The crusiders olimbed slowly over the rocky peaks of the mountalns in winter: they journeyed for days at a time in cold rain in spring; they passed over burning waste land in summer. Ien, women and horses died for want of water in the heat of the July sun because they did not know how to carry water in skins the natives did. They sometimes had to use sheep and goats to oarry the $1 \mathrm{r}$ bagsage. The rurks followed at a distance, shooting their arrovs at the siok, the waak, or any that could not keep up with the army. Those were terrible days for the Cruaders:

1. In the apring (a) moat of the arny was ready (b) none of the army was ready (c) all of the army mas ready.

2. The whole army (a) went one at a time (b) went in parts (c) went all at a time.

3. The Crusaders walked because (a) they liked to walk (b) it was sumer (c) there vas no other way to get there. 
4. The Crusaders found the journey very (a) hard (b) easy (c) restful.

5. Hany peple died because they did not know how to (a) milk the goats (b) carry water in skins (c) ride on thelr horses.

6. The Turks ghot arrows at the Crusaders from (a) the front (b) behind (c) in regular battle ilne.

7. Hore of the Crusaders died in (a) the winter (b) summer (c) the fall.

\section{IX}

The traders of Venice had bullt many ships to help carry the Crusaders to the Holy Land, so the well spare a tev for the Eastern trade. They began to make regular trips each year, taking with them slaves, mool, iron and leather. In every Christian city of the Holy Land they had a market in which they sold their goods. They bought from the natives or from anel tralns out of the Far East the goods for which they had come. In this way a great trade grew up between the East and the Fest. It was the stories of these traders that had made Marco Folo's father ish to go to China.

1. The ships from Venice were first built to carry (a) silk (b) Grusaders (c) cotton.

2. Then the ships from Venlce began to make regular trips, they carried (a) only soldiers (b) only slaves (c) many different things.

3. The traders of Venice had (a) many markata (b) fow markets (c) no markets.

4. Marco Polo's father wanted to go to China because (a) he manted to go on a Crusade (b) he liked the Chine se (c) he had heard stories of the East.

When the war was over, the natives and the Christians

became friendiy. The people from the west found out that those of the Bast knew many things whioh they themselves did not know. They learned how to ral se lemons, oranges, plums, watermelons, rice, and, best of all, sugar cane. 
They learned to use ginger and such splces as pepper and cloves. They loarned that they could color their clothing by the use of dyes, that $911 \mathrm{k}$ was much more beautiful than wool, and that glass oould be used for dishes. They found that carpets added to the comf ort of a room and that mattresses made beds softer. They learned the use of soap and began to bathe more of ten. The men began to shave. They used windmills to purp water. They had never known any of the se things at home, for life in the west was very al mple.

1. The people of the flest found that the people of the East (a) knew more than they did (b) know nothing at all (c) knew only about stars.

2. The people of the Fest found that the people of the Bast were (a) clean (b) dirty (c) filthy.

3. After the war was over the natives and Christians (a) got along well together (b) hated each other (c) fought each othar.

4. The people of the rast taught the people of the West (a) to sleep in beds (b) to bulld ships (c) to live more comf or tably.

\section{$X I$}

In that land Ilved John, called the "Ying of Good semory," with his five strong sons. Four of the boys were interested in zames, in court ilfe, and in war, we re most youth of their age. One, howerer. was very different Prinoe Henry was thoughtful and grave, spending most of his tiae in 8 tudy. Wany fine of fors to take aharge of armies were made him, but he refused them all. Then he became a man he left his father's court and bulit, far out by the sea, a tower in which to study the stars.

1. Prince Henry and his brothers liked (a) the same things ( $b$ ) difforent things ( $c$ ) everything.

2. Prince Henry was (a) noisy (b) gay (c) qulet.

3. Some people thought Prince Henry would make (a) a timal soldier (b) cruel soldier (c) a brave soldier.

4. Prince Henry left his father's court to (a) lead his armies (b) have a better place to study

(c) go to the Holy Land. 


\section{XII}

The prieats tried very hard to make Carletians of the Ind 1 ans. Since rost of the Indians lived out in the country. the priesto moved out into the eountry too. They learned the Indian languags s and built missions in the wildernass in order to teach the thil to men's ways of 11ving.

1. The priasts tried to teach the Indians about (a) Tashington (b) incoln (a) Chriat.

2. The Indians lived in (a) toms (b) citias (c) the country.

3. The priests found teachin: the Indians (a) easy (b) hard (c) i mpossible.

4. The priesta bullt misstons so as to have a better place (a) to thake the Indians work (b) to llve in conf ort (a) to tasch the Indlans.

\section{XIII}

The isen who had lived in Virginla took home ath them full account of the new land and eamiod sone of th plants to Rale 1 gh-monot the potatos and tobacoo. Ralelig planted the potatoes on his broad Iands and taught the courtlers to anoke bobacoo. The story is told

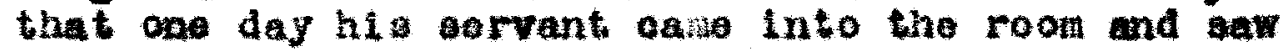
great clouds of anoke rising from his mator"g head. He ruahed out, aclzed a pail of water. and dashed it into Ralelgh' faoe. tearing that ha master was on fire.

1. Han wo 117ad in Viresnia took home (a) plants (b) aninal (c) oll.

2. Raleigh taught araking to (a) women (b) tho slave (c) poople of the ourt.

3. Ralelgh's servant thought his master was (a) slepplng (b) dying (c) burning.

4. Ma161gh* farn was (a) gmall (b) lange (o) about averago. 


\section{XIV}

The granting of a fief from an overlord to an underlord (or vassal, as he was called) was a very solem cersmony. The overlord sat on a high place, gurrounded by hls followers. The vassal approached, tell upon his knoes. put his handa between those of his lord, and promised to aerve him falthelily and woll. Then the overlord gave the vasaal a flef to hold for life or during good behavior. When this vassal died his son had to go through the same cerenony if he wanted to 11 ire on the ane land that his father had held.

1. The overiord sat (a) on the seat with his men (b) on a seat above his men (c) at a table with his men.

2. The overlord gave a fief to a (a) monk (b) sert (c) vassal.

3. The vassal had to (a) be vary old (b) be falthiul to his overlord (c) give his lands to his an.

4. If a vasal" son wanted his father'g lands he had (a) to make a promise to the overlord (b) bulid a church (c) ratse sheep on the lands.

\section{XV}

At last a ran named John Gutenberg showed the wor Id a moh shorter and asier way of printing. He made 1itile 1etters of 1ead, dozens of $a^{*} 3$, dozens of $b^{*}$, , and so on-some capital 1ettea and some sall. Those letters stood on a great table, in rows of wooden boxes. A workman took up the letters makling different nords, placed them in a Iittle metal Broors, and fastened them in. Then he put some thlck black ink on them, pressed a piece of white paper upon thea and took of the paper.

1. John Gutenberg showed people how to nake books (a) in a better way (b) in a longer way (a) in a harder way.

2. John Gutenber $3^{*} 3$ letters were (a) all cut into a block of wood (b) ail out out separately (c) set with a Inotype.

3. Gutenberg made his letterg of (a) wax (b) lead (o) stee 1 .

4. Gutenberg's printing press made it (a) harder to learn to read (b) eagler to learn to read (c) harder to get new books. 
The king of Spain kept up ha preparations wi th stubborm deteraination. In the apring of 1588 the Arada wa ready. It consl sed of one hundred and thirty-two groat ships, carrying throe thousand gans and hilrty thou and won. But there were too many goldiars and not enough saliors on board, and thare were fow skilled gunners.

thany of the ships were not warshipa, but only freight vessele pressed into aervioe to carry the army. And the officer in oharge was aldier who knew very littio about the salling of ships.

1. The Aranda (a) a floeb of ahips (b) a troop of boldiers (c) a battery of guns.

2. The Armada carried (a) only wallors (b) only soldiera (c) sailors and soldiera.

3. The Armada commander (a) did not know anough about anipg (b) was too old (c) did not like ships.

4. Heny of the silpa were (a) too old (b) too big (c) not bullt tor warkipa.

\section{XVII}

Aftor sove neoks they reached the top of a great range of nountaing and. looking dom, saw a lake wh th an lolans in the centar. On the ialand was the areat ot ty of textco, Jolned to the ratinland by five long bridges. The houses were of red atone covared aith a

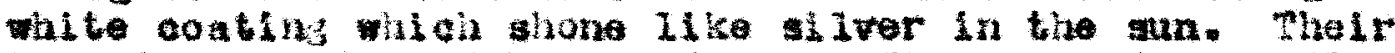
10. Ilat roof a had bas made into flower Bardens. It was clty of wonders. How oegerly the spaniards looked at 1t 1 Tey thought that at last they had arristod at

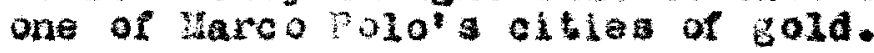

1. The island was joined to tho mainland by (a) canoa (b) hougas (c) bridges.

2. Iexico cisy mas (a) large eity (b) small elty (c) $11 t 61$ to tom.

3. the houses rore (a) dull and lark (b) danp and ugly (c) bright and bantiful.

4. Whon the Spanlards sav the of ty of Hexico they were (a) surpribed (b) di uppointed (c) andiry. 
THE ALERICAN PEOPLE AND TIEIR OLD WORLD ANCESTORS - VOLLINTINE

Name Sohool Orade

Date Time

Directions: 1. Read each paragraph.

2. Answer each question. Draw a line through the right answer as: "Loulgrille is a (a) house (b) exty (c) dog."

3. Tork $f$ aBt but AHSWER EACH QUESTION CAREFULLY

4. Put your nane at the bottom of each page right now--before you start to work.

Of Car greater value to Rome than her beatiful bulldings were her paved roads, for they led everywhere and connected the scattered parts of the Emplre as the rallroads of our nation bind our States together. One of the first things that the Romans did after conquering a country was to connect it with their city by means of a wide road. These roads were so well bulit that in some countries of westem Europe they aro in use today. They were laid out in straight lines, -mover hills, through mountalns, and across marshes and rivers. The bullders first cleared the roadway and packed the ground hard. Then they ather strewed sand or gravel over the bed thus ande or paved it with solid atones.

1. Rome was helped nost by her (a) ships (b) hlghways (c) bulldinga.

2. The roads of Rome were (a) curved (b) straight (c) crooked.

3. The Roman roads lasted (a) a short time (b) a long time (c) about ilve years.

4. The Roman roads were (a) paved (b) tarred (c) $0110 d$.

The winds of winter were raw and cold, so the Teutons wore clothing made from the skins of aninala. A few of the tribes knew how to tan animal aking and 
wake then into laather. Whoae tribes wore leather Garmente and andale. Some of the womon wore robas of wool or linen, for they had learned to nake oonrse cloth. Beoaute thay 117od moch out of doors in a harah climate. their bodiea wo re toughened and weather-beaten that they were eble to withstand grat hardahip and exposure.

2. The Teutong wore akins of animal (a) to keep them waris (b) because the wowen could not aew (c) because there wero no sheep.

2. The Teatons of tan 1ived (a) in tents (b) in cestias (c) out of doora.

3. Tho aktns the Teutong roro (a) soft (b) black (c) tough.

4. The Teutons ahould have made sood (a) soldiers (b) salosinan (c) clarks.

\section{III}

Poriups the ros inportant thing that ohar lemagne did for his people was to try to educate thes. That was not an easy task in his day, for books ware rare. Tiney were oostly too. for they had to be made of parehmen beange no papjrus could be obtalned tron saypt and paper was not then knom in surope. In spl te of soarolty of books Charlamagne had edueated hirase. It had oalled wise men to his palace and had eagerly learned trom them. They reas to hin from the fow papyrua rolla that atil survived. -priceless now because thoy contalned all that was lelt of the knowledigo of hlstory, gegraphy and numbers.

1. Books were acarce because (a) there wat no paper (b) tho wo could not raad (c) nobody wanted books.

2. Gharlemand thought the poopla should be (a) punl shod (b) oduoatod (c) entertainod.

3. Char lebagne learned froi (a) educated men (b) hl s chlidren (\&) Arablans.

4. Papyrus rolls were (a) cheap (b) worthlesa (c) of zreat value.

5. In Charlemagne"s time (a) 1 t was eay to get an education (b) it was hard to get an aducation (c) anyono could get an oducation if he wantod $1 t$. 
The fair-hai red Ang10-Saxon invaders had seen little or nothing but their wild German ghore until they landed in Romanized Britain. Therefore the towns and the fields of that 18 land seemed to them intended only for plunder. They raided settlements, robbed and burned ohurches, and destroyed gardens and orchards. Aftar that, for time, Britain had no towns, --only heaps of cinders and stones where cltles had once been. The Anglo-Saxons made no new towns, for they hated to live crowded together and shut in by walls. They settled far apart, each upon land received as his share of the stolen country.

1. The country from winch the Ang10-Saxons came was (a) warm and sunny (b) hot and ralny (c) wild and barren.

2. The Anglo-Saxons thought towns were made to (a) Iive in (b) heap up cinders (c) rob.

3. The Anglo-baxons (a) made towns in Britain (b) destroyed wat was in Britain (o) made Britain beautiful place.

4. The Anglo-Saxons lived (a) in town (b) close together (c) far apart.

During their ralds the Vikings left their wives and chlidren at home in the Northland. But at last the women too ranted to see the rich country from which came so wich plunder. So women and ohildren went with the shlps; and whon they landed on some fruitful shore, the vikings fought for land on which a new home might be built. Finally the French thought it better to glve the Nortimen land than to flght them (A.D. 911). So they bought peace for themselves by giving a wide distriot in weatern France that is knom today as Northman's Land, or Normand $y$.

1. The women wanted to cone to the new country because (a) they were tired of staylng at home (b) the new country had nice things in it $(0)$ they wanted a sea trip.

2. The women and chlldren landed in a place where (a) there was little to eat (b) there was plenty to Ilve on (c) nothing to live on. 
3. The French gave the Vikinga some land because they (a) llkad then (b) wanted to have peace (c) wanted to flaght them.

4. Norinandy is in (a) England (b) Belglum (c) France.

VI

The old Ioelandlo legends say tiat in the year 1000 or thereabouts Leif Hricsm axplorad the astem coagt of America, wh ch had been slibuted several years bef ore by the captain of a storim-driven viking ship. Leif found the mores of Newfoundland and Nova Beotia, and then, noving southward, landed on an Inviling coast overgrom wi th troes and draped with vines of the wild grape. Laif gave the nans "Ineland," or "Vinland, to the regl on, now thought to have boen part of Hasaachaetts or Rhode Island. He settled ther: and spent the wintor.

1. A viking ship can noar Anorica because (a) the wen were looking for Amarica (b) the $\operatorname{sh} 1 \mathrm{p}$ was ariven out of 1 to ourse by a storia (a) the wen were looking for leaf.

2. Leif found the siores of (a) Florida (b) Stexico (c) Newf ound land.

3. Leif called the country Viniand beause there were so many (a) troes (b) apples (c) grapes.

4. Vinland is thought to be part of (a) Kentuoky or Virginia (b) Greeniand or Fooland (c) masachusetts or Riode Isiand.

\section{VII}

3o Alfred declded that he mast met then before they reached his shorea, and dafeat thom upon the sea. The theref or started to bulld a fleet, and soon had a navy of more than a hundrod warahips. These ahips were like the viking shipe, but longor and broader. They were salft enough to overtake any engry because ach carried a hus sali and there wa apace for sixty or more rowers. In

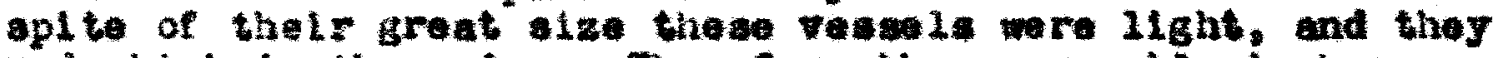
rode hi uh in the water. Therafore they were ble to keep afloat in shallow water, and they ran aground many an onery anip. Tt in this navy Alf rod was able wo win many viotories over Janes, Northan, and pirates. These gtaunch little aht pe were the beginning of tongland's mighty navy. 
1. Alfred started the Engliah (a) navy (b) banks (c) factoriss.

2. Alfred's sinips could fight well because (a) there were a hundred of them (b) they were big and olum (c) they were swift and could sail in shallow water.

3. Alfred won battles over the (a) Danes (b) Italians (c) English.

4. Alfred's ships were run by (a) steam (b) sails (c) sails and oars.

\section{VIII}

All who heard the Pope's appeal spread the word, and in the spring of 1096 great army--perhaps three hundred thousand people--collected along the Rhine, intent upon oapturing the Holy City, two thousand iniles away. Bach Crusader wore upon his breast a red cross as a sign that he had enlisted in a holy war; returning Crusaders were to wear the oross upon thelr backs. So great an arry could not move at once across central Europe. The miltitude was therefore separated into pive divialons, traveling by different routes and under different leaders.

1. Many people gathered along the Rhine because (a) they heard that the Pope wanted them to go to the Holy City (b) the army could not cross the river (c) they did not want to leave their homes.

2. The Holy Clty was (a) on the Rhine River (b) far away (c) just a tow miles from the Rhine River.

3. Each Crusader wore (a) clrcle (b) star (c) cross.

4. The army was divided because (a) the people could not got across the river (b) there were so many people (c) the people oculd fight better.

\section{IX}

The Italian me rahants became firmly established in Eastern ports during the Crusades. They had furnished ships $f$ or transporting Crusaders, had alded in capturing 
toms, and had furni shed gupplies to the conquerors. In whatever way an Italian oity gave help. It always had to be well pald. It usually demanded a place in the onquered city, preferably on a water iront, where 1 ts markets and docks would make a center for its commero. In this way Genoa, Venice, Analf 1 , and other Italian olties won trading quarters in Eastern ports.

2. The Italian merchants went to the East during (a) the Crusades (b) Spantsh war (c) Revolutionary war.

2. Trade from the Crusades helped (a) Paris (b) Venice (c) Lond on.

3. The Itallan merchants were (a) generous

(b) greedy (c) kindjy.

4. The Italian merohants always wanted a place (a) in the army (b) on the pilgrimages (o) where they could buy and sell.

Thousands of French, Germans, and English had traveled to the East by $l$ and and sea. Many of them were nobles; most of them were common people. Bome of mon had known nothine of the world beyond the estate upon which they were born. They had looked wi th wonder upon Constantinople, -1 ts public squares. 1ts fountains and palaoes. In other Eastern clties they had seen the homes of rulers and of wealthy merchants hung with tapestries, carpeted with rugs of velvet, and furnished in luxury. They saw for the first time how the East 11ved, and it made them want better things for themselves and more comfortable ways of living.

1. Host of the people on the Crusades were (a) nobles (b) comon people (c) slares.

2. The homes of the Eastern people were (a) beautiful (b) dirty (o) cold.

3. The people thought Constantinople (a) an ugly place (0) an unheal thy place (o) a wonderful place.

4. The homes of the Eastern people made the Western people want more (a) fountalns to bathe in (b) wore warm weather (a) more comfortable homes for themselves. 
In the meantlme there had grown to manhood in Lisbon the live sturdy sons of good King John. All of them were interested in knowing more of the geography of the world, and the fourth one, Henry, known as "the Navigator," apent his life in trying to find for Portugal that longed-for all-water route to India. Though he did not fully sucoed, he accomplished so large a part of the great undertaking that he is known today as the hero of Portugal and the leader of modern discovery.

1. Prince Henry liked (a) bames (b) aourt life (c) to know more about the world.

2. Trinoe Henry wanted to find out (a) how to get to America (b) how to laad an army (c) how to reach India by water.

3. Jenry is (a) honored by Portugal (b) forgottan by portugal (c) hated by Portugal.

4. Prince Henry (a) learned all about the way to India (b) learned the vay to Arerica (c) learned many things which holped others to find the way to India.

XII

Fron St. Augustine and San Gabriel the fathers pushed their way over the southern part of the continent. Fhen they had gained the friendship of the Indians, they gathered the into villages called missions. Each Indian had his own farm near the village, and he worked for two hours a day on land belonging to the mission, the crop of whioh were used to support the church of the Chriat. They al so taught reading, writing, music, and such useful handicrafts as blacksmi thing, carpentry, shoemaking and talloring.

1. The fathers tried to teach the Indians (a) more about geography (b) more about other Indians (e) how to have better homes and happier I1res.

2. The fathers ade (a) enemies of the Indians (b) nobles of the Indians (c) friends of the Indians.

3. The crops ralsed on the land belongling to the misions were used (a) to pay the Indians (b) to give to the Spaniards (c) to help the Church

4. The fathers (a) built their missions in one place (b) stopped when they came to a river (c) kept golng further and further across the country. 


\section{XIII}

In 1612 one of the farners, Join Rolfe, planted a field of tobacco. He had seen the Indians cultivating that plant in mall sardens, but he did not think the llavor of Virginla tobacco as as good as that of the fost Indies, ith wich Spain had been supplying Europe. After two years of cultivation, however, Rolfe produced a crop that was considered excellent both as to size of leaf and as to flavor. A small quantity of this orop was sent to $3 n g l a n d$, where it sold readily at good price. The news of this suocess spread, and as soon after every farmer of Jamestown was planting tobacoo on his patch of land with the stockade. Iven the sides of the streets and the market place were green with the growing plants.

1. John Rolfe thought the tobacoo in the west Indles (a) was better than that in Virginia (b) not as good as that in Virginia (c) was better than that in spain.

2. Rolfe found out that (a) he could not ralse tobacco in Virginia (b) it did not pay to raise it (c) he could raise very good tobacco in virginia.

3. Tobacco was raised because (a) the Indians taught the English (b) it was cagy to raise (c) it paid we 11.

4. Tobacco raising in Virginia grew (a) slowly (b) $r$ apidiy (c) not at all.

\section{XIV}

The men who onned land needed workers, and they needed warriors too, for no landomer was seoure while he had a trong neighbor. In order to give landomers the workers they needed, and to glve men who had no land protection and a means of support, feudallam gradually grev up. Under this plan a noble ho owned a small amount of land but who had no workers or warrlors joined hls land to the large estate of some lord or king. The lord had to agree to allow the noble a certain amount of land, to protect him, and not to interfere with the control of the land. The nobles who accepted the lord"s protection had to promise to be falthel to hin, to fight for him, and to go at least once a year to the lord's court to help decide cases of law. The men who made terms with the lords rere called rassals. 
1. Feudall $\mathrm{sm}$ was a kind of government that (a) gave the people more education (b) protected the people (c) made all the nobles stop flghting.

2. Hen who promised to fight for the lord were called (a) peasanta (b) fief (c) rassals.

3. The nobles took a row to be (3) faitheul

(b) pay taxes (c) build sehools.

4. Vassals had to (a) attend court (b) go on journeys (c) punlsh the lords.

The first printing was done from blocks of wood on which the words mere cut by hand, but the labor and uncertainty of this woodblock printing led men in Holland and cermany to experiment with movable type. It is - laimed that Laurens Coster of Holland made metal type as early as 1430. Soon after that John Gutenberg, who had been experinenting in the German town of Mainz, printed the Bible in Latin from morable type. The tase of type greatiy lessened the work of making books, for after the type had been set up, any number of coples could be quiokly made. If the printers had set their type with care, the coples would be correct and wuld be exactly allke.

1. The first printing was done on (a) lead plates (2) steel rollers (c) rooden blocks.

2. It is claind that Laurens Coster made (a) wooden letters (b) metal letters (c) a typomriter.

3. John Gutenberg printod a (a) novel (b) history (c) 3 iblo.

4. Movable type (a) made the work $310 \mathrm{ow}$ (b) made more mistakes (o) made printing easier.

XVI

Drake's raids ald not greatly affect Phillip's plans. He collected in Iolland and Bolfiun a large army, which he oxpected to send across the Engllsh Channel in barges. He also meant to send a great fleet of shipa into the Channel to guard tiie passage whlle the troops were being transported. When his silps were assembled in the river Tagus they numbered one hundred and thirty-two. Sixty-ive were galleons, the largest sulps evar made. Phillp felt so sure that this navy could never be conquered that ho called 1t the "Invincible Armada." 
1. The Invinoible Armada fas a (a) troop of soldiers (b) battery of guns (c) ploet of ships.

2. Phillip naeded his ships to (a) protoct his own siaips (b) carry the Crusaders (c) ship goods to England.

3. The Arrada had (a) 132 ships (b) 1000 ships (c) 67 ships.

4. Phillip was (a) afraid he would lose his shlps (b) afraid of Drake (c) sure that his ships could not be benten.

\section{XVII}

The Aztecs became builders in stone, and they erected many temples, palaces, and dwellings of hewn stone held in place with mortar. Their builders knew nothing of arches or domes, so the buildings were heary and bulky in appearance. They were decorated everythere with delicate carvings, for the Aztecs were famous as stone-cutters. For this work they used a knife or scraper nade of a very hard volcanic stone wioh was abundant in mexico. Some of the bulldings were made of a kind of ztone that could be highly polished. These shone so brightly in the sun that Spanish. explorers who first caught aight of then believed that they were silver.

1. The Aztecs built with (a) concrete (b) briok (c) stone.

2. The Aztoc bulldings ters (a) small (b) slender (c) $\operatorname{large}$

3. The bulidings looked like silvor because (a) they were made of silver (b) carved wh Pigures (c) were highly polished.

4. The work of the Aztec stone-cutters would be called (a) very poor art (b) very good art (c) very clumsy art. 
ELEMENTARY WORLD HI STORY - BEARD and BAGLEY

Name School Grado

Date TI me

Directions: 1. Read each paragraph.

2. Answer each question. Draw a line through the right answer as: "Loulgville is a (a) house (b) etty (a) dog."

3. Work fast but ANSWER BACH QUESTION CAREPULLY

4. Put your name at the botton of each page rl gint now--before you start to work.

I

In the course of time, the "august" emperor became the absolute master. The republic was changed into an expire ruled by one man wose word was law from one end of the ompire to the other. The emperors, as they followed one another through the passing years, brought huge storea of treasures to the of ty of Rome. They built grand public buildings, huge trlumphal arohes, great highways, 1 mmense pubilo batis, and vast theaters to furnish sport for the poople of the oity. They tried hard to keep the oitizens at Rome contented. They gave food to the masses. They amused them with shows in the open-air theaters, where men called gladiators fought one another with swords or fought with liong and tigers - "every form of man or beast the broad empire of Rome could furnish." Never had the world behold such splendid buildings, suoh wealth, such display of riches, such pomp and pride.

1. The Roman emperors (a) built up the ofty (b) destroyed the bulldings (c) killed the people.

2. The mperor of Rome was (a) a kind and just ruler (b) a beloved king (c) a man whose word was law.

3. Rome at the time was a city of (a) poverty (b) ruin (c) riches.

4. The emperors of Rome wanted to (a) $k 111$ all the tigers and 11 ons (b) tear down the triumphal arohes (c) keep the oftizens happy. 
Thouands of Germane, also organlzed as tribes Qoths, Franks, Anglos, and Saxons - Invaded Roman terr tory under powerful and daring cheta. One of thene bands, the weat Gotha, comanded by Alarlo, even captured and 100 ted the clty of Rome 1 teent in 410 A.D. Thu the very spot from whion Roman armis had once gone forth to aubdue the eartio was itself in the hands of conquerora.

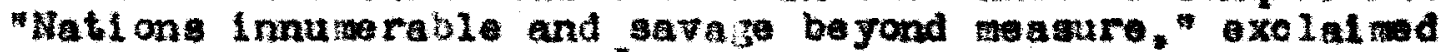
the Christian sonk, 3t. Jeromo, have Imaded all Gaul. tro wold reglon between the Alps and the Pyrenese, the oeean and the Mhine has been devastated.. O mrotohed enolre

1. The Gormans were divided into (a) armies (b) nations (c) tribes.

2. Rotw was captured by (a) Luther (b) Phil11p (c) Alaric.

3. The dertana were (a) peaceable (b) oivilized (c) avage.

4. The Germang (a) bullt great altea (b) deatroyed To: (c) taught the pooplo Chribtianity.

III

The wost fanous of the Garolindan cinge was Charlemagme or Charle the areat. who relgned from 758 to 814. He lidened ht kingdon to include large portions of Dermany and Italy as we 11 as France. The was a fleree warrior wen flyhting $11 \mathrm{~s}$ nalghbores at the same time he was a friend to peace in his own country. Fie sant hisalonaries to the he athen in the foreats of eastern Germany, bul1t magnificent palaces, and took pride in erecting beautiful churches. He save money to found schoola. He even tried to learn how to mrlte af tar he becane a man; he kopt tablots at his side so that he coula gractico henover he had a littio tine to epare. Uniapplizy ha be

gan too 1 ate in $11 f$ and conld not mater the art. The ranks at his court, honever, conld write. and thay kopt reord of his brave daede. 1. Klng charlewagne was (a) brave (b) cowardiy (c) anguet. 
2. Charlemagne set up (a) theaters (b) Ilbraries (c) schools.

3. Charlemagne kept tableta at his side so that (a) he could write dom all the things he learned (b) so that ho could find out things $f$ or the priests (c) so that he could learn to write.

4. Charlemagne wished the people of the country to be (a) Christians (b) Mohamedans (c) Unrellgt ous.

5. Charlemagne did not leam to write because (a) the priesta did not know how (b) there were no pens $(a)$ he was too old to learn.

6. We know that Charlemagne was a brave man because (a) lots of people knew him (b) people were afrald of him (c) the monks wrote about him.

\section{IV}

Before wany years had passed, the English, as we may now call the various tribes of Angles and Saxons who had come to ald the Britons, turned against their allies. They began a war to win Britain for themseires. For a century or more the terrible contest went on. Fealthy Romans pled with their gold and silver or burled the treasure in the earth. One after another, the old Roman towns fell into the hands of the Invaders. Christian churches were burned. Even the priests were slain at the altars. By the year 557, all southern and eastern Britain had been selzed by bands of English, each headed by its own war lord.

1. The Anglo-Saxons (a) were always good Iriends to the Britons (b) becane enemies of the Britons (c) went ay and left the Britons in peace.

2. The Anglo-Baxons (a) burned the towns (b) bullt churchea (c) established schools.

3. Many wealthy Romans (a) joined the Anglo-Saxons (b) captured Eritain (c) left Britain.

4. The Ang10-Saxons wanted (a) to help the Romans (b) to give part of the land to the Romans (c) all of the land for themselves. 
Yet the lisland was not to find peace. The victore turned againat one another. For two and half oenturies Ingllat chlef hains fought atong themselve to gain the whole of Britain as a prize. At length, In B28, one of

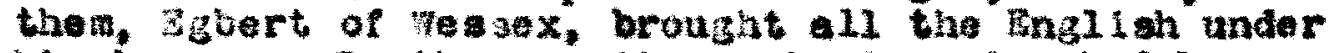
his banner. In the antlas ficsionarles had been adtive and had convortod the Bnilish to the Ciristian falth. Churohes and nonateries had risen all over the land. and monks wore busy th weir guil1s witung down lato and cironlalas or roords of lmportant happeninge.

1. The Ingl ah oileftalns were (a) roady to help ach other (b) jealous of anoh othar (o) relped evaryody*

2. The unt on of the Engligh was helped by the worik of the (a) chleftains (b) pirates (c) mis alonaries.

3. Fis anks Frote with (a) lead penoils (b) styles (c) quili pens.

4. The 3nglish ware united under one leader (a) in a short tine (b) In a long tine (c) during the 2ifo of thair oldogt man.

\section{VI}

Thl new solduer of for tuns wa 1111 an, the Duke of Hormandy. Prom northern Franos, He was the de scendant of a vora ditoftain and pirate who had raided the coats of France and then aethled dom there as a rassal. or underlord, of the Fronch king. milliam himelf was born fighter of zroat strenth and dreadil crualty. "So fleroe was he," wrote a chroniclar of his th that none dared to real at his 11 ." No one else vas strong enough to beand

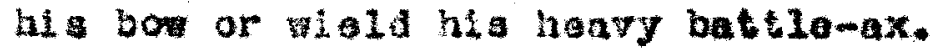

1. Tillaw was (a) a spaniard (b) a Frenchman (o) an Italian.

2. 倠1111am's great-arandf ather had been (a) monk (b) ing (c) pirate.

3. 111 lan was the sort of king who made every one (a) Lovo hln (b) foar him (o) want to givo him woap on s.

4. H111an vas vory (a) toak (b) sick (o) strong. 


\section{VII}

In the land that remained $A$ if red ruled with wi ad on and justice. Ho won $t$ or hinself a place in history as one of the noblest English kings. A brave warrior himalf, he knew how to lead an army in defense of his country. He was a wise lawglver. Ho collected the laws of England, taking, as he said, those which seemed $r$ ightest to me." Deeply interested in education, he had a school at his court, and wi shed that every treeborn boy should "abide at his book until he can well understand English writings." Alfred also gave money and land to the church. He loved the English tongue and translated many Latin books into his native language. Not content with making mere translations. Alfred of ten added Ideas of his own. He hated the cruelty and tyramy of Roman emperors and declared that all off 1 cers ought to rule sely and fairly. One of his friends sald of him that day and night Alfred labored to see that justice was done to his subjects, "for in the whole kingdom the poor had no helpers, or few, save the king himself." Alfred made the beginnings of English literature and set an example of a king who wiehed to be "a father to his people." He died in 901 , one of the most beloved monarchs of all history.

1. King Alfred ruled his people with (a) cruelty (b) visdon (c) selfi shness.

2. Alfred thought that all free-born boys should

(a) learn Latin (r) understand English witing

(c) atudy to be a priest.

3. Alfred thought that fonan rulers ruled of th

(a) fairness (b) wi sdom (o) cruelty.

4. Alfred was a friend to (a) all the people

(b) only the poor (o) only the realting.

\section{VIII}

In a strange way, the trade of Europe was increased by the rise of the Rohamedans whose armies tried to conquer Christendom. All the eastern and gouthern shores of the uediterranean, including Palestine with the tomb of Christ, fell into their hands. To resoue the Holy Land from the Uohamedans, the Suropeans of all nations began, In 1096, a series of wars known as the Crusades. These lasted for more than two hundred yeara. Kings, prinoes, knights, common soldiers, monks, peasants, artisans and 
even ohlldren flocked to the armies that made the periloun journeys to distant Pale atine. In those crusades, thousands of people perished by the vayside or were killed in battle. Other thousands lived to make theis way hore and tell stirring tales about their adventures and about the countries through whlch they had passed.

1. The Cruaades were wars (a) to get Aserica

(b) to capture Drake (c) to take the Holy Land from

the Sohaninedans.

2. The Mohamedan armies were (a) good flibters

(b) timla flghters (c) comards.

3. Many poople died on the way to the Holy Land because of (a) the many hardinlps on the way (b) they fought among themselves (c) they were imights.

4. Of the people who went (a) all were kllied (b) many came back (c) very few came back.

IX

Moreover, travelers frot western Burope had seen the great city of Constantinople, where some signs of Home"s former glory were stili to be found. Adventurers then learned how to trade with the merohants of the East and heard from them tales of India and China. Espeoially did the Italians profit from the Crusades. The merohants of Genoa and Venice hoaped up great supplias to the crusading armies, and founded colonias and trading conters on the eastern shores of the Mediterranean.

1. Constantinople was a wonderful sight to the Crusaders because (a) it was in the East (b) many people lived there (c) some of the bulidings put there by the Romans were still standing.

2. In Constantinople the people heard stories of (a) China (b) Tapan (c) Russia.

3. The Italians found the Crusades (a) a great help to the $1 r$ trade (b) kept their ships from the East (c) rulned their trade.

4. The merchants of Genoa became (a) very poor (b) very rich (c) very lazy. 
In the end, the tomb of Chriat was not won by the Chrlatian crusaders. As of ten happens, the results were very different from what had been expected. Instead of hating the Mohamedans and all their ideas, the crusaders grew to like many things they saw in the Bast. Men 1 rom England, France, Germany and Spain got new wants and tastes when they sam the Iuxuries of the East. They becane discontented with the rough life they had led. Henceforth they must have spices, silks, rugs, gold and silver ornaments, and precious stones from the Rast. Their neighbors caught the sams spirit as they heard wondrous stories of $f a r$ countries, rich in luxurles.

1. The crusaders (a) took the tomb of Christ amay from the Mohammedans (b) had to let the Mohammedans keep it (c) shared the torb of Christ with the Mohammedans.

2. The people of the Fest grew (a) to like the people of the East (b) to hate them (c) to learn that they re all thieves.

3. The Vesterners learned that the Easterners had (a) only old and ugly things (b) things that no one would want (c) some very beautiful things.

4. The Crusades made the people of the Test (a) better satisfied with their we sern ways (b) glad that they did not have to IIre in the East (c) want the things they saw the people of the Bast using.

\section{$X I$}

The way for this great undertaking was made easier by the son of the Portuguese king. Prince Henry, farou in history as "the Navigator." Though brave in battio and skilled in directing armies, he was less interested in the arts of war than in the arts of peace. He refused to become a high officer in the army. He chose instead to Ilve on the lonely cape of Sagros at the remotest point of Portugal looking out southwest over the sea. There he bullt a home and an observatory. There he brought together astronomers, geographers, and map makers. He sent floot after lieet down the coast of Africa in search of the southern passage.

1. Prince Henry was most interested in (a) leading armies (b) lighting battles (c) studying about geography and the stars. 
2. Prince Henry tried to find the way to (a) Amerioa (b) Je rusalem (c) the Indies.

3. Prince Henry bought maps th (a) the king's money (b) the people's money $(c)$ his om money.

4. Prince Henry helped aen who wanted to be (a) navigators (b) array captains (c) sohool teachers.

\section{$X I I$}

A third Spant ah captain, Do Soto, aought fame and wealth by making an expedition into Fiorida and the wilderness to the west. Instead of rich cities, however. he found a few native Indians living in wretched huts; instead of fortune, he met his deatin on the banks of the Hissisippi River. Other oxplorers, vorking northward from Hexico, traveled over the landa now included in Texas, Arizona, and New hexico and planted the Spanish flag in many a trading post and missi on which they $f$ ounded.

1. De soto wanted (a) to get rich (b) to teach the Indians (c) to live with the Indians.

2. De soto was (a' pleased with what he found (b) di sappointed (c) became weal thy.

3. Spanish explorers established (a) colonies (b) trading posts (c) neither.

4. Sore of the Bpaniards were (a) slaves (b) missionaries (c) tenanta.

\section{XIII}

Comerce, whlle making the se changes within the nations, also became a powerful cause of wars anong tiem. The desire for new 1 ands and new markets led to bitter jealousies. Frinceg had long fought over territory in gurope. Now whole nations were to waje wars for territory and trade in all parts of the world - over profits from tea, suzar, coffee, and splces.

1. Trade caused (a) people to love one another (b) to flght one another (c) to give their landa to each other.

2. War was fought over (a) trade (b) the Indians (c) schools. 
3. War has been caused by (a) new house (b) new sarkets (c) new books.

4. Traders who sold spices (a) lost money (b) made money (c) cane out even.

\section{XIV}

The power of the king was also increased by the help he had from the nobles. They were fev in nubar, and no common man could ever become a noble unless the $\mathrm{king}$ raised him to that rank and gave hin a titie. Huch of the land of Encland was omed by these rioh lords dukes, earls and barons. On thelr lands they lived 11ke princes, although they could no longer defy the king as thelr ancestors had done. They were not independent: they were loyal subjects of the king. They held high of 1 ces under hin and served him in many ways in war and peace.

1. The nobleg made the king (a) weaker (b) stronger (c) kinder.

2. A common man became a noble (a) when the king died (b) winen he becaine rich (c) when the king gave hin a title.

3. The land of England was owned by the (a) comron people (b) nobles (c) king.

4. The nobles (a) did as they pleased (b) obeyed the king (c) pought the king.

\section{XV}

The name of the parson who really made the first printing press is not known. Gutenberg and Faust in Germany and Coster in Holland are among those to whom the credit has been given. As in the case of most inventions, the idea was in the ir and many mon were at work on $1 t$. We do know, nowever, that a Bible was printed at Mainz, in Cerwany, in 1456. That year may wall be taken as openting the age of the printing press.

1. The printini press was invented by (a) a man in Germany (b) a man in Ilolland (c) many men.

2. One of the first books printed (a) a history book (b) an arithetic book (o) the Bible. 
3. The first printing of the Bible is important because it tella us (a) about the Bible (b) when printing started in Germany (c) that Coster 1ived in Holland.

4. One of the first towns to use a printing press was (a) London (b) Paris (c) Mainz.

XVI

The king of Spain, greatly angered at Drake's exploits, made ready for war on ingland. In 1588 he sent a powerful Plest of warships, the Armada, to the English Channel to drive his Engligh rivals from the sea. But instead of winnine a zreat victory, the spanlards suffered a terrible defoat. The Spanish navy was badly crippled and the English no longer foared it.

1. Spain fought England because she (a) wanted England (b) did not like the things Drake was dolng (c) wanted to trade with ingland.

2. The Armada as (a) an army (b) a tloet of ships (c) a knight.

3. Spain lost her ships (b) defeated England (c) won the war.

4. After 1588 England wa (a) afraid of Spain (b) not afraid of Spain (o) an ally of spain.

\section{XVII}

In exploring the mainland of America the lead was taken by soldiers bearlng the banner of Spain and by missionaries bearing the crosa of Christ. One of the great Spanish warriors, Ferdinand Cortez, in 1519 discovered texico -- a vast ompire with fortile farms, prosperous citios and zreat stores of gold and silver. In a shor time he conquered $10 x i c 0$, selzed the told and silver of its rulers and made it a part of the Spanish Empire.

1. Spain was helped in Amertea by her (a) merchants (b) mechanlos (c) missionaries.

2. Mexico made Spain (a) rlcher (b) poorer (c) less powerful.

3. Then Cortez discovered Mexico he found (a) poverty (b) ricies (c) monasterles.

4. Cortez (a) took the gold away from the people of 2exico (b) gave the llexicans money for their gold (c) taught the Mexicang how to spend their money. 
BIOLPONAMT 


\section{BIBLIOGRAPII}

1. Ayer, Adelaide M.,

Some Difficulties in Elamentary School histary. Teachers College Contributions to Education, No. 212. Teachers College, Columbia University, New York, 1926, pp. 10, 16, 30, 32, 48-49.

2. Anderson, I. R.,

"Testing Basic Skillg in the Social Studies." Elomentary School Journal. Volure 36, (Fobruary, 1935), pp.424-35.

3. Bagley, Fillam C., "The Textbook in American Education." Sohool and Society, Volume 33, (March 14. 1931), p. 358.

4. Barr, A.S., and Gifford, C.

"The Vocabulary of American History." Journal of Educational Research. जolume 20, (Se tember, 1929), pp.103121.

5. Bobbitt, Prankiln, How to Make a Curriculum. Boston,

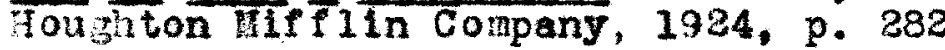

6. Book, William F., "Analysis of the Task of Learning to Read." Journal of Educational Research, Volume 21,1920, p.2

7. Bourne, Henry $\mathrm{E}$., The Teaching of History and Civica in the Elementary and the secondary School. New York, Longmans, Green Conpany, 1912, pp. 157-8.

8. Buckingham, B. R.,

"The Scientif ic Development and Evaluatins of Te thooks." Department of Buperintendents, offioial Reporta, (rebruary 25, Haroh 2, 1933), pp. 159-166.

9. Burch, Mary C.,

"Determination of a Content in Literature of a Suitable Diffleulty for Juni or and Senior Students." Worcester, Zass., Genetic Psyehology Lonographs, Volume 4, Nos. 2 and 3, (August-September, 1928), Clark University Press, pp. 260-261, 288 . 
10. Burks, Jesse D.,

"Relative effectiveness of Two Different Plans of Training in Sllent Reading." Elementary Sohool Journal, Volum 29, (September, 1928June, 1929), pp. 431-436.

11. Burnside, Margaret, An Experiment to Determine Whether a Test Hay Be Derised to Find Out if a Piece of Literature is Plaoed Cor rectiy in the Currioulum. Haster's Thesis, School of Education, Indiana Univergity, Blooming ton, Indiana, Auguat, 1933.

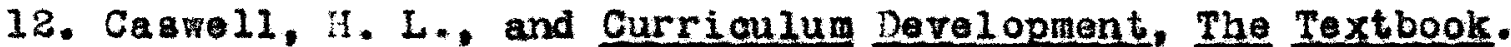
Campbeli, S. D., New York, American Book Company, 1935, pp. $45-47$.

13. Charters, 7.7.

Currioulum Construotion. New York, The lacrillan Company. 1924, p. 344.

14. Cutright, Prudence, "A Study of One Factor in the Grade Halvor son, Ge or and Placement of Reading Faterials." Elementary School Journal, Volume 29, Bruackner, L. J., (September, 1928), pp. 284-295.

15. Dewey, Joseph C.,

A Case Study of Reading Comprohension Difflouitios in Amerioan History. Abstract of Doctor's Dissertation, College of Education, State Universi ty of Iowa, I owa City, $1331, \mathrm{pp} .47-48$, $51-54$.

16. Distad, H. 筜.,

"A Study of the Reading Porf ormanoe of Pupils Under Different Conditions on Different Types of Material." Journal of Edncational Payohology, Volume 18, (Apri1, 1927), pp. 247-58.

17. Dolch, Edward v.,

"Combined Ford Studies." Journal of Educational Mesearch, Volume 18, (January, 1928), pp. 11-19.

18. Doloh, Ratward

"Testing Ford Difficulty." Joumal of Educational Researeh. Volume 26 , (September, 1932), pp. 22-27. 
19. Doran, B. 彨.,

"A Stuay of Vocabulary." Pedagogical Seminary. Volume 14, 190\%, pp.401-38.

20. Dunlap. A. ... and tandbook of stati stioal Monosrapha. Kurtz, A. K.. iables and formulas. New Tork, Foria Book company. 1932, pp. 4, 5, 14, 13, 90, 113,137 .

21. Fennel1, Zthel L., "Necurrins to Dit: iculty in compraienst on." Ilemenuary seheol Journal. Volume 29 . (September. 1926), pp. 42-53.

22. Tranzen, $\mathrm{n}, \mathrm{\pi}$, , and

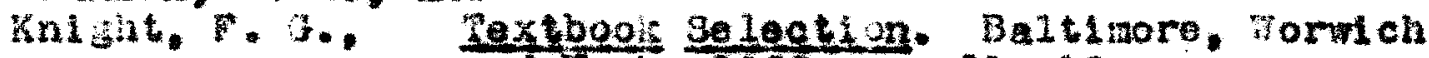
and tork, 1922, pp. 11. 19.

23. Fuller, Fiorenoe. Bcientifle Evaluation of Taxtbookg. Boston, Toughton tiffien Company, 1928. p. 56 .

24. Garrott, Hanry E. statiatica in pychology and gducation. Hov York. Longana Green kompany. 1932, p. 29.

25. Gales, Arthur I., The Paychology of Reading and Jpelaing Spec Lal Totarence to Disability. Feabers College contributions to Edueation, Wo. 129, Hew York. Teachers Collegte, Colunbla Untvorsity, 1322. pp. 53,108 .

25. Gates, Artur I. "An Ixperimental and statistioal Study of Reading:" Journal of Edugational pavchologz, (october. Novemer and Decenber. 1921 ).

27. Satos, Arthur 1., The Impravement of Beading: 1 Program I Dianoatic and hernedal hethods. Now York. Tho Nackinan Company. 1935.

28. Gates, Artur I., "The conatruction of a pleading Vocabulary $f$ or the Prinary Orades." Teachers Golleze Reeord volume 23. (5eptember. 1925), pp. 46-51. 
29. Gates, Arthur I.,

30. Gates, Arthur I.,

31. Gray, 佣111iam S.,

32. Gray, willian 3..

33. Hilliard, George H.

34. lockett, John A.,

35. Horn, Ernest,

36. Horn, Ernest,

37. Humphrey, J. M. ,
A Reading Vocabulary for the Primary Grades. Bureau of Publioations, Toachers College, Columbla University. New York, 1928.

"A Study of the Role of Visual Perception. Intelligence, and Certain Assoclative Processes in Reading and Speli1ng." Journal of Educational Parchology, Volume 18, (October, 1926). pp. 433, 445.

"The Nature and Organization of Basto Instruction in Reading." Thirty-gixth Yearbook of the National soclety for the Study of Education, Part I. Public School Publishing Company, Bloorington, Illinois, 1937, Chapter IV.

"Sunrary of Investigations," Elementary School Journal, Volume 27, (July 1, to June 30, 1926 and February and Harch, 1927), pp. 456-66, 495-510.

Probable Trpes of Difficultioe Underlying lost Skil1s in Comprehensi on Testg. University of Iowa studies in Education, Volume 2, No. 6, Iowa City, Iona, 1924, p. 160.

"The Vocabularies of Primary Readers." American Educational Association, A Department of the National Educational Association, official Report of the 1935 Heeting, st. Louls, Missour 1 , (February 22-26, 1936), pp. 271-4.

Methods of Instruction in the Soolal Studies. Charles Scribner's Sons, Now York, 1930.

"Tho Objectives of a Reading Guide to Remedial and Prophylactio work." Yearbook No. 2, Department of ElementarySchool Principala, National Education Association, 1923, p. 204.

The Determination of the Vocabularles in the Junior High school. Haster's Thesis, University of Chioago, Chicago, III inois, 1925. 
38. Hue $\mathrm{g}$, Edaund $\mathrm{B} \cdot$,

39. Irion, T. . .

40. Jacobs, L. B.,
The Psychology and Pedazogy of Reading. New York. The Hacmilian Company, 1912. Chapters II. III and IV.

Comprehengion Difficulties of NinthGrade Students in the study of Literature. Teachers Coliege Contributions to Education, No. 189, New York, Columbia University, 1926, pp. 34-5.

"Elghteen Criteria for Choosine New "extbooks." The Glearing Hou se. Volume 2, No. 8, (Apri1, 1937). pp. 485-86.

41. Jensen, Frank J.,

"The Selection of Ianuseripts by Publishers." Thirtieth Yearbook of the National society for the Study of Education, Public Sohool publising Company, Bloomington, Illinois, 1931, pp. $80-91$.

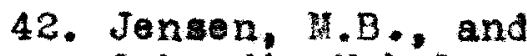
Sohrodt, Mabel,

Language Diffioulty and Learning: the Relative Effectivonesa of a Serios of Study Sheets of Graded Difficulty as Teaching Devices with Chlldren In the 6A Grade." Journal of Genetic Psychologx, Volume 49, No. 2, (December, 1936), pp. 451-467.

43. Johnson, Henry,

Teaching History in Elementary and Secondery Schoolg: Nen York, The Macmilian Company, 1916, pp. 279-80.

44. Johnson, George R., "An Objective Method of Determining Reading Difficulty." Journel of EduceLonal Research, Volume 21, Apri 1 . 1930), pp. 283-37.

45. Kelty, Mary G.,

"Time Expressions Comprehended by Children of the Elementary School." Blementary Bahool Journel. Volume 25, Pp. 522-528.

46. Kilburn, H. Parley, An Analygis of Ameriagn Texts in the Eighth Grade and an Evaluation of Content or laterials of Current Bighth Grade History Texts 1 coording to the objectives Set up by the Anerican Historical Assooiation. Haster's Thesis, Utah State Agricultural College, Utah, 1932. 
47. Kirkpatriok and Burch, of Sohool Efficlenoy." Sehool and Soclety, Volume 2 , 1915, pp. 713-18.

48. Kniss, F. R.,

49. Keboch, F. D.,

50. Link, H. C..

51. McCall, william C.,

52. Maj1, J.A.,

53. Maxwe 11, Charles R.,

54. Meliza, Dorothy,

55. Nice, Margaret M.,

56. Nolte, Karl F.,
"Program of Diagnostic Testing and Remedial Teaching in For ld H1 story." Sooial Studieg, Volume 28 , (November, 1937), pp. 312-14.

"Variability of Ford-Difficulty in Five American History Texts." Journal of Educational Researoh. Volume 15 , (January, 1927), pp.22-6.

"How Many Interviews Are Necessary for Results of a Certain Accuracy." Journal of Apelied Paychology, Volume 21, (February, 1937), p. 5.

How to Experiment in Education. New York, The Macmili an Company, 1930, pp. 46, 57-58.

"Vocabularies." The Pedagoglcel Seminary, volume 26, pp. 209-33.

"The Use of Score Carda in Evaluating Textbooks." Thirtieth Yearbook, Part II, of the National Soclety for the Study of Eduoation, Publlo School Publishing Company, Bloomington. Illinols, 1931, pp. $80.143-146$.

"Effective Reading in a Hi story Class." Reading and the Sohool Library, (Earch-Apri1, 1937), pp. $138-140$.

"Length of Sentence as a Criterion of a Child's Progress in Speech." Journal of Educational Paychology, Volume 16 , (September, 1925): pp. 370-79.

"Simpliflcation of Vocabulary and Comprehensi on in Reading." Elementary Engli gh Revien, Volume No. 4, (Apri1, 1937), pp. 119-24. 
57. Ogden, C. K.,

58. Pell, George R.,

59. Powers, S. R.,

60. Pressey, L. C.,

61. Pressey, L. C., and Lively, B. A.,

62. Pressey, L. C.,

63. Pylo, villiam

64. RugB, Harold,
The System of Basio English. Now York, Harcourt and Brace Company, 1934.

A Scale for Meaguring High School Textbooks in History. Uaster's the al $b$, University of Chloago, Chlcago, Illinois 1930, pp. 28-30.

"The Vocabularias of ligh School Sclence Textbooks." Teachers College Record, Volume 25, 1925, pp. 368-382.

"The Detarmination of the Technical Vocabulary of the School 3ubjects." Sahool and Society, volume 20. (July, 1924), pp. 91-96.

"A 许ethod of Yeasuring the Voeabulary Burden of Textbooks." Educational Adrainiatration and Superriaion. Volume 9, (October, 1923), pp. 389-98.

"The Technical Vocabulary of the Public School Subjects." Section 5, Ameriean History, Public School publi sining Company, Bloomington, I1linois, 1925 .

The Paychology of the Common Branches. Baltimore, Warwiok and York, 1930, p. 77 .

"Curriculum-making via National Comittees." Trenty-gixth Yoarbook of the National Society for the Study of Education, Public School Publishing Company, Bloomington, Illinois, 1927, p. 55 .

55. Schorling, Ralph, and Edmonson, J. B.,

"The Technique of Textbook Authors." Tilitieth Yearbook, Part II, of the National society for the study of Education. Pubilc School Publishing Company, Bloomington. Illinols, 1931 . pp. $111-115$. 
65. Se 1ke, Brioh and Selke, G. A.,

67. Smith, H. S.,

68. Smock. Lenna 5.

69. Stevens, Marion P.,

70. Symonds, Parcival $H_{*}$

71. Terman, L. M.,

72. Thorndike, R. L.

73. Thorndike, E. L, and Bvans, Annio L. Kennon, Laura $\mathrm{H}$. Newdomb, Ral th $I$.

74. Thornd1ke, E. L.,
"A Study of the Vocabulary of Beglning Books in Twelve Reading Methods." Elementary Sohool Journal. Volume 22, (June, 1922). pp. 145-49.

The Eating of the Vocebalery of $31 x$ Amorican Hi torr Textbooks for Seventh and 2ighth Gradeg. Master's Thesls, Univeraity of Chicago. Chloago, Illinois, 1926.

A Study of Intermediate Textbooks Cornonity ued In the Stete of Indlana ith spectal Fererence to the ReIative Difficul ty of the Vocabulary and Length of Sentenoe. Master's Thesis, University or Indiana, Bloomington. Indiana, 1929.

"Comprehensi on Tegta in the Reading Prozram." American Childhood. volume 22, (November, 1936), pp. 46-7.

Size of Recognition and Recall Vooabularies." Sohool and Society. Volume 24, (October 30,1926$)$. pp. 559-60.

The Heagurement of Intelligenoe. Boston, Houghton Hiffin Company. 1916, pp. 226, 261 .

"Vocabulary of Books for ChIldren in Grades Three to Flght." Teachers College Record, Volume 38, (Deeember. 1936 and February, 1937), pp. 196205, 316-323, 416-429.

"An Inventory of English Construetions with Heasures of Their Importance." Teachers College Record. Volume 28, (February, 1927). pp. $580-610$.

A Teacher's ord Book of the Trenty Thousand Words Found Most Frequenty and ide1 in teneral Reading for Children and Young Peoplo. Bureau of Publications, Teachers College. Columbia Univeraity. New York, 1932. 
75. Thorndike, E. L.,

76. Tryon, Rolla H.,

77. UhI, 洋lis, L.,

78. Voge1, Mabe 1, and Washburn, Cariton,

79. Vesley, Edgar B.,

80. Wheat, Harry G.,

81. Fitty, Paul A., and Le Brant, Lou L.,
The Teacher's Word Book of Ten Thousand Tords. Bur eau of Publioations, Teachers College, New York, 2923.

Teaching of History in Junior and Senior High Sohool. Boston, Ginn and Company, 1921, pp. 67-8.

"The Materials of Reading." Thirty-sixth Yearbook of the National Soelety for the Study of Education, Part I. Educational Diagnosis," Public Sohool Publishing Company, Bloomington, Illinols, 1937, Chapter VII.

"An Objeotive Hethod of Determining Grade Placement of Chlldren's Reading Materials." Elementary School Journal. Volume 28, (January, 1928), pp. 373-81.

"Diagnosis in the Social Studies." Thirty-fourth Yearbook of the National Society for the study of Bducation, Part I, Educational Diagnosis," Public School Publishing Company, Bloomington, Illinois, 1935 .

The Paychology of the Elementary School. Newark, N.J., Silver. Burdett Company, 1931, pp. 234-5.

"Vocabulary and Reading." School and Soclety, Volume 31, (February 22, 1930), Pp. 268-72. 